\author{
Universidade de São Paulo \\ Instituto de Física \\ Programa de Pós-Graduação Interunidades
}

Aspectos da Natureza da Ciência em Textos de Divulgação Científica:

Análises a Partir de um Diálogo entre Kuhn e Popper

Arthur Pereira Scabora

São Paulo

2021 


\author{
Universidade de São Paulo \\ Instituto de Física \\ Programa de Pós-Graduação Interunidades
}

\title{
Aspectos da Natureza da Ciência em Textos de Divulgação Científica: Análises a Partir de um Diálogo entre Kuhn e Popper
}

Arthur Pereira Scabora

Dissertação apresentada ao Programa de PósGraduação Interunidades em Ensino de Ciências, no Instituto de Física da Universidade de São Paulo (IFUSP), Campus Butantã, para a Defesa de Dissertação de Mestrado, como parte dos requisitos para obtenção do título de Mestre em Ensino de Ciências.

Área de Concentração: Ensino de Ciências Linha de Pesquisa: História e Filosofia da Ciência Orientador: Prof. Dr. Ivã Gurgel

São Paulo 
Autorizo a reprodução e divulgação total ou parcial deste trabalho, por qualquer meio convencional ou eletrônico, para fins de estudo e pesquisa, desde que citada a fonte.

FICHA CATALOGRÁFICA

Preparada pelo Serviço de Biblioteca e Informação do Instituto de Física da Universidade de São Paulo

Scabora, Arthur Pereira

Aspectos da natureza da ciência em textos de divulgação científica: análises a partir de um diálogo entre Kuhn e Popper. São Paulo, 2021.

Dissertação (Mestrado) - Universidade de São Paulo. Instituto de Física. Depto. de Física Experimental.

Orientador: Prof. Dr. Ivã Gurgel

Área de Concentração: Física

Unitermos: 1. Física (Estudo e ensino);2. Ensino; 3. Cientistas; 4. Professores de ensino médio.

USP/IF/SBI-045/2021 
Dedico este trabalho a todos os Mestres, do passado e do presente, que abriram o caminho para que eu pudesse por ele caminhar. 


\section{AGRADECIMENTOS}

Este trabalho é fruto de um extenuante esforço de pesquisa, meditação e redação, cujo alcance e profundidade superou em muito minhas expectativas iniciais. Tal esforço teria sido absolutamente impossível sem os auxílios que recebi.

É por isso que sou e sempre serei profundamente grato, primeiramente, ao meu irmão Luiz, cuja inesgotável sabedoria e inabalável companheirismo me guiaram e não me deixaram desistir mesmo nos momentos mais caóticos.

Sou também imensamente grato ao caríssimo prof. Ivã Gurgel, cuja orientação sempre precisa e ponderada mantiveram-me no centro de minha busca. Não é por acaso que tantos são os que procuram sua orientação, e nem por acaso que ele já se tornou uma respeitável referência de toda uma geração de pesquisadores e educadores em Ciências.

Devo igualmente agradecer aos professores Vinícius Carvalho e Alexandre Bagdonas pelos preciosos apontamentos realizados no exame de qualificação. Sem dúvida, o presente trabalho pôde ser muito mais refinado e polido ao ter tais indicações como guia.

Por fim, sou grato ao Centro Paula Souza, cujo suporte financeiro viabilizou essa intensa e longa jornada. Estou plenamente consciente de que é um verdadeiro privilégio ter acesso a esse tipo de assistência, e o mínimo que posso fazer em retribuição é contribuir com uma melhor qualidade em meu trabalho como docente do CPS, função essa que exerço com alegria há quase uma década. 
"Tudo o que acreditamos conhecer sobre o mundo físico depende inteiramente da suposição de que existem leis causais. [...] A questão da justificação de nossa crença na causalidade pertence à teoria do conhecimento [...]."

Bertrand Russell

"Nós, e aqueles que partilham de nossa posição, esperamos efetuar descobertas novas e esperamos ser auxiliados, nesse trabalho, por um sistema científico que acaba de aparecer. Teremos, por isso, o maior interesse pelo experimento falseador. Saudá-lo-emos como um êxito, por ele ter aberto horizontes novos num mundo de experiências novas. Saudá-Ioemos ainda que essas novas experiências nos forneçam argumentos novos contra as nossas mais recentes teorias."

Karl Popper

"Se a história fosse vista como um repositório para algo mais do que anedotas e cronologias, poderia produzir uma transformação decisiva na imagem de ciência que atualmente nos domina." 


\section{RESUMO}

Este trabalho realiza uma análise crítica da visão de Ciência predominante, especialmente nos meios de divulgação científica, sob o olhar das ideias de Karl Raimund Popper e Thomas Samuel Kuhn. Em particular, analisa duas questões fundamentais, a saber: "O que é Ciência?" e "Como a Ciência progride?". Investigando as respostas usuais a essas perguntas, em contraste com o que nos diz a história da Ciência e os resultados dos trabalhos dos filósofos citados, foi verificada uma notável discrepância, em grande parte responsável por distorcer a visão que o público em geral tem da Ciência. Essa distorção pode ser sintetizada em três pilares: cientificismo, o movimento anticiência e as pseudociências. Foram analisados: (1) os principais erros conceituais cometidos pelos divulgadores, (2) as consequências sociais e educacionais de se ensinar a Ciência sob essa ótica distorcida e (3) formas alternativas de se abordar o grande tema da "Natureza da Ciência". É também feita uma defesa aberta da Filosofia como essencial ao empreendimento científico. Conclui-se com um panorama geral do ensino e da divulgação científica na atualidade e perspectivas para o futuro.

Palavras-chave: História da Ciência, Filosofia da Ciência, Ensino de Ciências, Divulgação Científica, Pseudociências, Cientificismo. 


\begin{abstract}
This work carries out a critical analysis of the prevailing view of Science, especially in the vehicles of scientific dissemination, from the perspective of the ideas of Karl Raimund Popper and Thomas Samuel Kuhn. In particular, it analyzes two fundamental questions, namely: "What is Science?" and "How does science progress?". Investigating the usual answers to these questions, in contrast to what the history of Science tells us and the results of the works of the aforementioned philosophers, a notable discrepancy was found, largely responsible for distorting the general public's view of Science. This distortion can be summarized in three pillars: scientism, the antiscience movement and pseudosciences. The following were analyzed: (1) the main conceptual errors made by the disseminators, (2) the social and educational consequences of teaching Science from this distorted perspective and (3) alternative ways of approaching the great theme of "Nature of Science". An open defense of Philosophy is also made as essential to the scientific enterprise. It concludes with an overview of teaching and scientific dissemination today and perspectives for the future. Keywords: History of Science, Philosophy of Science, Science Teaching, Scientific Dissemination, Pseudosciences, Scientism.
\end{abstract}




\section{SUMÁRIO}

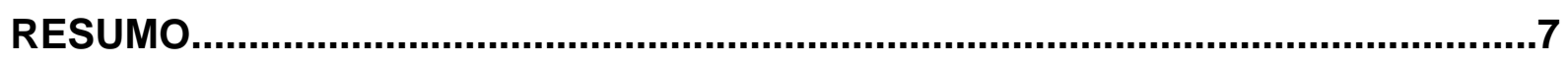

INTRODUÇÃO...............................................................................................11

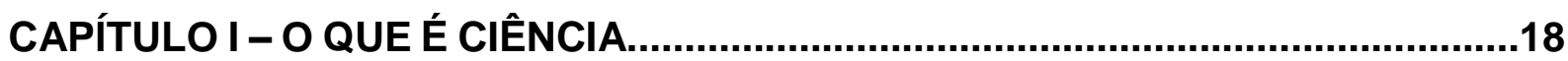

1.1 - O Problema da Demarcação e a Solução de Popper..........................................21

1.2 - Implicações do Critério de Demarcação de Popper............................................24

1.3 - Críticas de Kuhn ao Critério de Falseabilidade de Popper..................................29

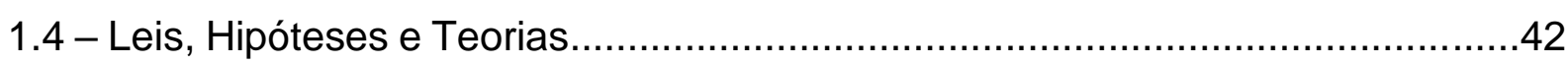

1.5 - Predição, Observação, Experimentação e Descobertas...................................51

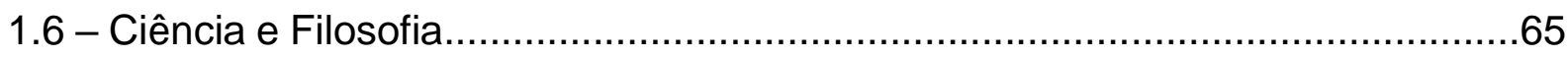

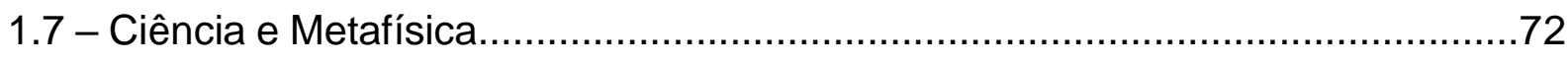

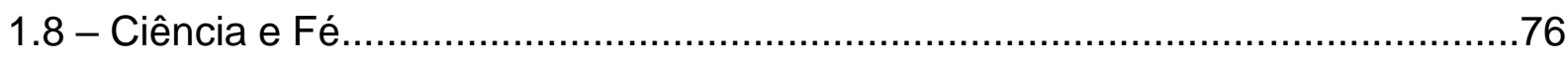

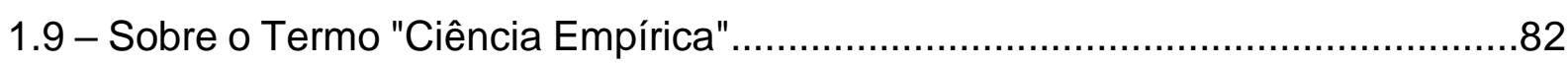

1.10 - Três tipos de distorções na visão acerca da Ciência........................................91

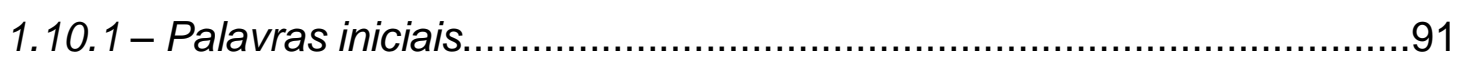

1.10.2 - Primeiro modo de distorção: Cientificismo.......................................92

1.10.3 - Segundo modo de distorção: Anticiência........................................108

1.10.4 - Terceiro modo de distorção: Pseudociência....................................109

1.10.5 - Comentários sobre o Terraplanismo e o Movimento Antivacina......113

CAPÍTULO II - O PROGRESSO DA CIÊNCIA...................................................119

2.1 - As fases da Ciência de acordo com Comte..................................................120

2.2 - As fases da Ciência de acordo com Kuhn...................................................126

2.3 - As tarefas científicas - O que um cientista faz? .........................................129

2.4 - Revoluções Científicas e Mudança de Paradigma.......................................134

2.5 - Progresso Científico versus Progresso Tecnológico........................................144

CAPÍTULO III - ENSINO E DIVULGAÇÃO CIENTÍFICA......................................152

3.1 - Comentário sobre a BNCC e sobre os livros didáticos.....................................154

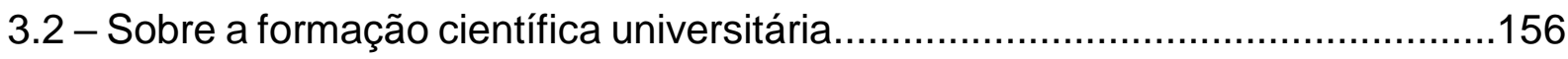

3.3 - Breve análise de alguns livros clássicos de divulgação...................................164

3.3.1 - Método de Análise......................................................................166

3.3.2 - O Mundo Assombrado Pelos Demônios - Carl Sagan - 1995.............166

3.3.3 - O Grande Projeto - Stephen Hawking e Leonard Mlodinow - 2011....179 
3.3.4 - O Gene Egoísta - Richard Dawkins - 1976 ................................186

3.4 - Breve análise de alguns livros modernos de divulgação..................................191

3.4.1 - Astrofísica para Apressados - Neil deGrasse Tyson - 2017...............191

3.4.2 - A Ilha do Conhecimento - Marcelo Gleiser - 2014............................198

3.5 - Sobre a divulgação científica na Era da Internet..........................................205

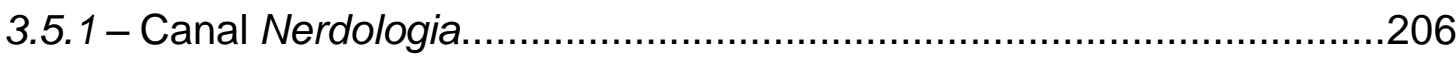

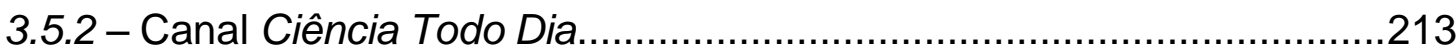

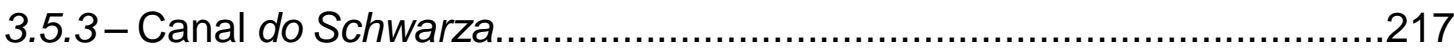

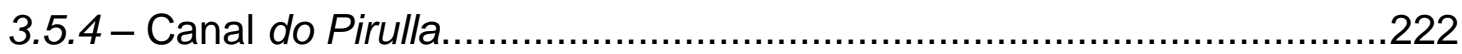

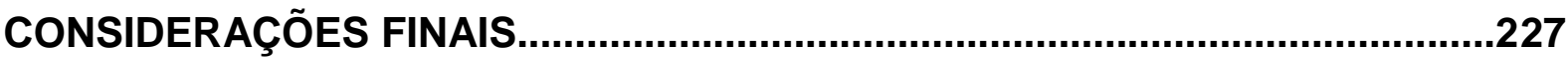

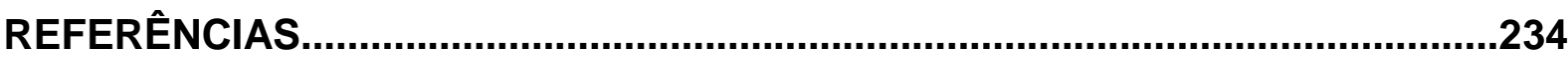

APÊNDICE: PROPOSTA DE UMA NOVA VISÃO PARA TEORIAS........................240 


\section{INTRODUÇÃO}

Em um mundo inundado por tecnologia e onde a informação é distribuída mais velozmente do que podemos acompanhar, a relação que, enquanto sociedade, temos com a Ciência tem apresentado mudanças drásticas. Há um conflito de correntes de informação e de desinformação acerca do que é a Ciência, de como ela progride e de como ela nos afeta; um conflito em que a divulgação e a educação científica são protagonistas, e apenas se bem coordenadas e bem realizadas poderão levar ao triunfo no que se refere à construção de uma consciência científica pautada no que "é", e não no que "ouviu-se dizer que é". Mas, antes, é necessário compreender a natureza do problema, que de forma alguma é trivial, mas que clama por uma solução: definir o que é Ciência, seus objetivos, seus limites, seus métodos, assim como descrever corretamente como ela atua e progride. Tal foi a tarefa dos filósofos da Ciência ao longo dos séculos, e parece que a questão permanece mais atual do que nunca. Afirmam Bagdonas, Zanetic \& Gurgel (2014, p. 248):

"Responder a questões como 'o que é a ciência?' envolve tensões entre especialistas de diferentes áreas do conhecimento, como história, filosofia e sociologia das ciências, a psicologia, as visões dos próprios cientistas sobre a sua prática e até mesmo as demandas dos cidadãos em geral sobre como a ciência deveria ser."

Como podemos ver, a tarefa não é fácil. Por exemplo, é lugar-comum afirmar que a Ciência, como empreendimento humano que é, apresentou extraordinário progresso nos últimos séculos. Ao apreendermos esse fato, uma multiplicidade de questões surge diante de nós: Qual a natureza desse progresso? Até que ponto esse progresso é comparável, se é que o é em algum, ao progresso observado em áreas mais ou menos próximas, como as Artes, a Filosofia e a Tecnologia? O estudo desse progresso é meramente descritivo, analisando como ele se deu através da história passada, ou teria esse estudo algum uso prescritivo, possibilitando a predição e o direcionamento consciente dos rumos do progresso? Estaríamos caminhando para um objetivo definido (a "verdade"), ou estaríamos navegando em águas desconhecidas, sem saber onde há, e se há, algum porto seguro mais adiante? E as questões seguem ad infinitum, tanto quanto quisermos aprofundar ou esmiuçar o nosso entendimento sobre como a Ciência progrediu. 
Muitas dessas perguntas são de pouco interesse à maioria - mas não todos, é claro - dos praticantes comuns da Ciência. Muitos seguem sua rotina de trabalho apartados dos grandes debates acerca desses assuntos. Por outro lado, tais questões são de interesse maior ao historiador, ao filósofo da Ciência, ao epistemologista, e também ao divulgador e educador, que se debruçam por tentar compreender, ordenar e estabelecer, tanto quanto possível, bases sólidas ao conhecimento humano e de como ele foi obtido. Não ignoro que muitos dos grandes nomes da Ciência foram também, em grande medida, ou ao menos como "segunda profissão", filósofos - e talvez, por isso mesmo, seus trabalhos tenham produzido resultados mais profundos e duradouros do que os de seus pares que tinham pouco ou nenhum interesse nesses assuntos. Mas até que ponto podemos dizer que o conhecimento histórico-filosófico da Ciência influenciou o seu desenvolvimento? Ou será justamente o oposto: foi a maneira como a Ciência se desenvolveu que determinou as descrições históricofilosóficas deste mesmo desenvolvimento? Ou, talvez, tenha sido uma simbiose indissociável, uma alimentação recíproca, contínua e edificante de ambas as correntes de estudo que acabaram por levar o conhecimento humano às alturas em que se encontra hoje?

Neste trabalho, pretendo analisar essas questões, algumas mais do que outras, sendo essa priorização devida, em parte, às grandes dificuldades intrínsecas das questões em si, e em parte pelas limitações de possibilidades que uma dissertação de mestrado apresenta. Felizmente, estarei "sobre os ombros de gigantes" ao fazer essa análise - os ombros de Karl Raimund Popper e Thomas Samuel Kuhn, duas figuras-chave do século $X X$ no que concerne a investigação de respostas às indagações feitas acima.

Ambos os filósofos ${ }^{1}$ trabalharam arduamente para clarear os caminhos e os rumos da Ciência: o primeiro, de um ponto de vista mais metodológico, lógico e formal; o segundo, de um ponto de vista mais histórico, prático e concreto. Essa diferença de abordagens, que se chocam radicalmente em muitos pontos (Kuhn, vale dizer, foi um grande - e, talvez, o mais influente - crítico da abordagem de Popper), acaba por

\footnotetext{
${ }^{1}$ Faço a ressalva de que Thomas Samuel Kuhn considerava-se mais como um historiador da Ciência do que como filósofo propriamente dito. Apesar disso, claramente, em sua Magnum Opus, A Estrutura das Revoluções Científicas, Kuhn ingressou — sem direito à passagem de volta - ao mundo da filosofia da Ciência, motivo pelo qual referir-me-ei a ele mais como filósofo do que como historiador.
} 
fornecer uma rica fonte para o diálogo referido no título dessa dissertação². As duas principais obras utilizadas como referência foram aquelas que consagraram os filósofos ao status de que desfrutam até hoje: $A$ Lógica da Pesquisa Científica ${ }^{3}$, de Popper, e A Estrutura das Revoluções Científicas ${ }^{4}$, de Kuhn. Quando referenciadas, por motivo de economia, usarei os termos $A$ Lógica e $A$ Estrutura ${ }^{5}$, respectivamente.

O século XX foi um período muito frutífero para a Filosofia da Ciência. Algumas dezenas, talvez mais, de filósofos se destacaram nesse campo, todos empenhados em compreender a Natureza da Ciência e encontrar algum sentido ou direção nos rumos que ela tem tomado. Surge então a questão da motivação por trás de escolher justamente Popper e Kuhn ao invés de outros estudiosos quaisquer. Acompanhando a divulgação científica, em especial a mais recente, realizada no vastíssimo campo virtual da Era da Internet, foi notado que Popper é o filósofo mais citado por divulgadores da Ciência. Especificamente, o seu famoso Critério de Demarcação é usado eventualmente como definição do que é e do que não é Ciência, normalmente afirmado com enfática segurança e aparente consenso. É, pois, como o grande público tem o seu primeiro contato com a Natureza da Ciência ${ }^{6}$, uma vez que o sistema educacional tradicional não tem dado conta de fornecer esse mesmo tipo de saber. Esses divulgadores parecem ignorar que o Critério de Popper foi severamente criticado nas décadas que seguiram o lançamento d'A Lógica e essa postura tem gerado consequências indesejadas à própria Ciência que dizem defender. Foi justamente para contrapor essa visão que o segundo filósofo escolhido para o diálogo

\footnotetext{
2 Em Cardoso et al. (2015, p. 245), encontramos o seguinte dizer: "[...] existe uma base comum na forma como conceber a NdC [Natureza da Ciência] no trabalho de importantes autores como Karl Popper, Thomas Samuel Kuhn, Stephen Toulmin, Imre Lakatos, Paul Feyerabend, Larry Laudan e Ronald Giere, e que esta base deve estar trabalhada com o fim de facilitar a compreensão da construção do conhecimento científico". Certamente, não é por acaso que Popper e Kuhn são os dois primeiros nomes da lista!

${ }^{3}$ Editora Cultrix, São Paulo, 2013. Trad. Leonidas Hegenberg e Octanny Silveira da Mota.

${ }^{4}$ Editora Perspectiva, São Paulo, 2013. Trad. Beatriz Viana Boeira e Nelson Boeira.

${ }^{5}$ O próprio Kuhn costumava referir-se ao seu livro com o termo Estrutura. Ver Kuhn, 2013, p. 10.

${ }^{6}$ Uso o termo Natureza da Ciência como sinônimo do conjunto de concepções históricas e filosóficas acerca dos elementos da Ciência, assim como de seus mecanismos de atuação, metodologias e demais características distintivas. A bibliografia utilizada como base para tal concepção será explicitada logo adiante. Nas palavras de Bagdonas \& Silva (2013): "A 'Natureza da Ciência' (NdC) é um conceito bastante complexo e dinâmico, uma vez que envolve os resultados de pesquisas de diversas áreas, como a história, filosofia e sociologia das ciências, além de ciências cognitivas, como a psicologia".
} 
foi Kuhn — por ter sido, provavelmente, como já dito, dentre todos os muitos críticos de Popper, o mais influente.

Mas, afinal, onde reside a importância de se conhecer a Natureza da Ciência? A resposta é complexa, como normalmente o são as respostas para questões filosóficas, mas elas estão certamente de algum modo acessíveis e, como sugeri no primeiro parágrafo, assumem importância central nesta era de "ensino e divulgação científica digital", assim como importam ao cientista que, a exemplo dos grandes nomes já comentados, sabe que beber da fonte filosófica pode fazer toda a diferença quando as novas questões que surgirem cobrarem respostas arrojadas, a exemplo das que deram Planck, Einstein e os demais "pais" da Física do século XX.

A formação cultural $^{7}$ de uma pessoa desta Era, qualquer que seja a cultura original a qual pertença, dificilmente poderia ser considerada completa se the faltar um entendimento mínimo da Ciência tal como ela é. Em consonância com muitos pesquisadores que tratam do tema, resumem Köhnlein e Peduzzi (2005, p. 62):

"Para que a educação científica possa subsidiar o aluno no exercício de uma cidadania consciente e atuante, ela deve ir além do simples ensinoaprendizagem de fatos, leis e teorias científicas. Entre outras coisas, é preciso também proporcionar ao estudante uma compreensão crítica da natureza da ciência e da construção do conhecimento científico."

É evidente que uma resposta definitiva sobre "como a Ciência é" não existe, e possivelmente nunca existirá, pois trata-se, em grande parte, de uma explicação interpretativa. Já faz décadas que os avanços em Filosofia da Ciência enfatizam que a prática científica não pode ser caracterizada de uma forma simplista; não há uma única e definitiva "Natureza da Ciência" (Driver et. al., 1994; Bagdonas \& Silva, 2013). Mas, justamente por existirem diferentes abordagens possíveis, é irresponsável ensinar uma única visão como sendo "a" visão definitiva. A abordagem deve migrar do que é consenso para o que é não-consensual, pois se podemos afirmar algo sobre a realidade, é justamente que não há consenso sobre o que é essa mesma realidade. A formação científica escolar básica, assim como os veículos de divulgação científica, precisam assumir suas respectivas tarefas com seriedade e solidez, sendo que a principal dessas tarefas é, penso eu, justamente fornecer uma visão realista, humana

\footnotetext{
${ }^{7}$ E, é claro, para além da formação cultural, nunca podemos nos esquecer da formação cidadã de futuros adultos que precisam do conhecimento científico para atuar efetivamente na sociedade e em seus problemas (Praia et al., 2007; Henrique, 2011).
} 
e pujante da Ciência. Queremos minar os "mitos da ciência", usando um termo de McComas (1998). Infelizmente, o que se nota nesses veículos é justamente o serviço oposto: a Ciência é apresentada ao público como um ideal (e, portanto, em grande medida, irreal) (Köhnlein \& Peduzzi, 2005), estéril, e dotada de uma aura pseudoesotérica, impenetrável ao leigo e conhecida apenas pelo ente-cientista ${ }^{8}$, que é - e isso é quase sempre subestimado - principalmente e antes de tudo, humano. Essa distorção pode estar na raiz do afastamento do público em geral da Ciência, uma vez que esse mesmo público não se sente comungando desse conhecimento; conhecimento que, saiba ele ou não, lhe pertence por direito ${ }^{9}$. Isso é grave por si só. Mas o século XXI acabou surpreendendo a muitos quando deu origem a outro problema, cuja raiz pode muito bem estar, assim como está no problema anterior, na distorção da visão de o que é Ciência e de como ela funciona. Falo de tal problema a seguir.

Em uma época em que a divulgação da Ciência é muito mais veloz do que a nossa capacidade de bem ensiná-la, abriu-se margem para a propagação desmedida de ideias ingênuas, para não dizer perniciosas, sobre o que é Ciência e como ela é concretamente praticada pelos cientistas. A tendência atual às polarizações fez com que surgissem grupos "cientificistas", prontos para defender a todo custo a visão idealizada e irreal de Ciência, em oposição aos grupos "anticiência", dedicados a solapar a credibilidade científica. Enquanto os primeiros superestimam o alcance e a validade da Ciência e de suas explicações, os segundos vão pelo caminho do extremo oposto, subestimando esses mesmos aspectos. E, perdidos na "terra de ninguém" que é a zona intermediária entre o pseudomisticismo, a superstição e a Ciência, ainda há o problema das assim chamadas "pseudociências", que buscam se aproveitar da credibilidade que a Ciência tem, mas sem apresentar os resultados e as metodologias rigorosas que ela requer. Um foco maior da crua realidade do empreendimento científico, entendido como empreendimento humano — incluindo aqui tudo o que isso

\footnotetext{
8 Isso é visto, por exemplo, quando se apela às autoridades acadêmicas, dizendo que "pessoas comuns" não devem debater certos assuntos científicos, pois os "especialistas cientistas" sabem o que estão fazendo.

${ }^{9} \mathrm{O}$ argumento que uso aqui é: se a Ciência é parte da cultura humana, tanto quanto as Artes, a Filosofia, e as Religiões o são, todo o seu domínio - no caso, o conhecimento do mundo natural - a todos pertence, desde que cada qual capacite-se minimamente para obtê-lo. A educação e a divulgação científica têm como papel primordial auxiliar nessa aquisição, sem a qual um indivíduo estará apartado de sua própria cultura (a cultura humana) em um ponto basilar (a cultura Científica).
} 
acarreta -, pode ser um sólido ponto de partida para uma mudança dessa visão. Essa é a proposta da presente dissertação.

É bom lembrarmo-nos que não é de se estranhar que a guerra ideológica tenha chegado aos domínios da Ciência: nunca na história a Ciência foi tão parte da cultura popular, sendo ensinada e divulgada, de maneira mal ou bem feita, de forma massiva, em livros, canais de TV especializados e, sobretudo, na internet (Massarani, Leal \& Waltz, 2020; Navas et al., 2020). Havendo em nossa geração certa tendência para arrefecer conflitos armados e guerras civis, a guerra ideológica passou para o campo das ideias ${ }^{10}$. A internet mostrou-se a melhor candidata à arena: deu conhecimento, informação (que são, afinal, as armas e a munição do conflito), visão, espaço e voz a quem antes não tinha. Defendo, por isso, que entender e enfrentar tais "insurreições" anticientíficas e pseudocientíficas precisa passar pelo estudo do papel da internet no ensino e na divulgação da Ciência. Tudo isso será devidamente abordado ao longo deste trabalho.

Apesar de frequentemente falar de conceitos sob uma perspectiva generalista, tenho um alvo claro, definido e específico com o presente trabalho: entender como a Natureza da Ciência é ensinada e divulgada, identificando os erros mais comuns nas abordagens correntes, e oferecer subsídio teórico para que a qualidade geral desse mesmo ensino e divulgação seja incrementada. Assim sendo, o terceiro e último capítulo desta dissertação é o seu coração: é ali onde analiso casos de divulgação, ilustrando com exemplos reais os equívocos cometidos pelos divulgadores. Os capítulos primeiro e segundo têm o propósito de servir ao terceiro; neles, fiz uma revisão teórica dos pontos-chave sobre os quais todo educador em Ciências precisa se debruçar, e dificilmente poderá se abster de discutir e refletir a respeito. O leitor que esteja interessado apenas nas questões concernentes à divulgação científica pode ir direto ao Capítulo III, retornando aos Capítulos I e II apenas quando - e se - sentir necessidade de esclarecer um ou outro argumento por mim utilizado na análise dos materiais.

Por fim, deixo aqui um pequeno esclarecimento acerca do tom do presente texto. O leitor poderá notar que, eventualmente, teço ásperas críticas a ideias que considero não apenas erradas, como também perniciosas. Espero que o leitor

10 Esse trecho foi escrito entre novembro e dezembro de 2019. Tendo em vista o ano "apocalíptico" de 2020, deixo ao leitor a tarefa de julgar se tal afirmação continua procedendo ou não. 
também perceba que as críticas são sempre direcionadas às ideias e aos conceitos, e jamais aos autores. Não há ódio ou raiva envolvidos (quem me conhece sabe que não alimento e não dou voz a esse tipo baixo de emoção), mas apenas uma atitude de impulso por depurar até o extremo toda e qualquer ideia, com a mais rigorosa, precisa e bem concatenada argumentação, a fim de jogar alguma luz no que eventualmente se mostra confuso, obscuro ou mal compreendido. Deixo claro aqui, tal como repetirei esse alerta mais duas ou três vezes no decorrer da dissertação, que não espero menor rigor das críticas direcionadas às minhas próprias ideias e conceitos. Ao contrário, aguardo com avidez tais críticas, não para discutir ou entrar em contenda, mas na esperança de poder aprender algo com elas, refinando e retemperando incessantemente minha própria cosmovisão e seguir sempre sustentando a busca por maior lucidez. 


\section{CAPÍTULO I - O QUE É CIÊNCIA}

Definir o que é Ciência, assim como classificar as diversas Ciências, é uma tarefa ao menos tão antiga quanto os trabalhos de Aristóteles (ver, por exemplo, sua análise no Livro VI d'A Metafísica). Não foram poucos os filósofos que trataram de realizar tal tarefa. No século XIX, quando o lluminismo deu seus resultados com máxima pujança, August Comte estabeleceu a doutrina Positivista e a sua classificação particular das Ciências. Antes dele, porém, Immanuel Kant já havia se ocupado de tentar demarcar nitidamente o território da Ciência e da Metafísica (ou de qualquer outro campo de conhecimento considerado "não-científico"), entendidas como áreas essencialmente diferentes (Popper, 2013, p. 35). Mesmo após quase dois séculos recebendo críticas agudas, ainda hoje predomina a visão positivista, inclusive entre cientistas, de que a Metafísica é incompatível com a Ciência, "desnecessária" e até mesmo "desprovida de sentido" (como afirmou, por exemplo, Wittgenstein — ver Popper, 2013, pp. 344-5) — ponto que será aprofundado mais adiante nesta dissertação.

O problema de se definir o que é Ciência (e o que não é) encontrou uma, e talvez a mais bem sucedida, solução com Karl Popper em seu clássico A Lógica da Pesquisa Científica. Compreender essa solução, com todas as suas implicações e problemas derivados, é fundamental para a formação de uma visão científica que seja atual e livre, tanto quanto possível, de distorções. Tal problema e solução serão analisados na próxima seção.

Como já adiantei na Introdução, tivemos ao menos algumas dezenas de grandes nomes na Filosofia da Ciência ao longo do século XX. Eles dedicaram-se a expandir e a clarear as definições e limitações dos conhecimentos científicos. Não se chegou a um consenso, mas sem dúvida houve avanços. O presente trabalho, porém, não é dedicado a esses "estudos de fronteira". Meu intuito é partir de noções relativamente mais antigas (como as de Popper e Kuhn), e isso por dois motivos: (a) tais ideias tanto tiveram mais tempo de amadurecimento, crítica e revisão, ao mesmo tempo em que (b) parecem não terem ainda sido absorvidas pela divulgação e pelo ensino de Ciências. Com relação a esse último ponto, devo esclarecer alguns tópicos, o que faço a seguir.

Sem dúvida, é abundante a produção acadêmica sobre tais filósofos, assim 
como sobre o impacto que suas ideias tiveram no nosso entendimento da Natureza da Ciência e de seu ensino. No entanto, ao estar em contato constante com a sala de aula, o que inclui contato com outros professores de Ciências, além do acesso frequente às novas coleções de livros didáticos, vejo que os avanços acadêmicos ainda não chegaram ao front da batalha pela educação científica. Pude verificar o mesmo fenômeno ao analisar proeminentes trabalhos de divulgação científica, tais como os que abordarei no Capítulo III ${ }^{11}$. Hoerning, Massoni e Lima (2020, introdução) notam que "apesar de a comunidade de Pesquisa em ensino de Física apontar há décadas a necessidade de inserção de discussões de visões epistemológicas na sala de aula, isso não é um consenso para a comunidade de físicos ou mesmo para a comunidade de educadores". Parece haver um "gargalo", uma espécie de barreira que tem impedido um diálogo efetivo entre os acadêmicos e os educadores/divulgadores, de forma que a prática desses últimos aparece como estando muito defasada com relação ao que já foi desenvolvido pelos primeiros.

Assim, meu objetivo é estar mais próximo da prática docente ${ }^{12}$, onde, sobretudo no Ensino Médio, é mais importante fornecer bases consolidadas do que entrar em discussões acadêmicas complexas que ainda estão em andamento ${ }^{13}$.

Este primeiro capítulo visa fornecer um panorama geral dos elementos constitutivos da Ciência. Muito já foi escrito sobre a natureza e a função que as teorias, as observações, a experimentação, a descoberta etc. exercem na Ciência. Por exemplo, encontramos em Lederman et al. (2002, pp. 150-2) um resumo de sete tópicos fundamentais para o ensino da Natureza da Ciência, a saber: (a) o caráter empírico da ciência, (b) a distinção entre leis e teorias, (c) o caráter criativo do conhecimento científico, (d) a teoria como guia do conhecimento científico, (e) a influência mútua entre o contexto sociocultural e o conhecimento científico que é produzido, (f) a inexistência de um método científico único e (g) a natureza provisória

\footnotetext{
11 No citado capítulo, analisei a divulgação científica feita por meio de livros e vídeos no YouTube. No entanto, os exatos mesmos problemas encontrados nesses veículos podem ser também identificados na divulgação feita, por exemplo, na televisão, tal como retratado por Rocha (2012), Porto e Schmiedecke (2015) e Bagdonas, Zanetic e Gurgel (2017), e em meios jornalísticos, tal como retratado por Cardoso et al. (2015).

${ }_{12}$ Eu realmente tenho a esperança de que o presente trabalho seja lido por professores e divulgadores de Ciência. Se tal esperança é vã, o tempo dirá.

${ }^{13}$ Ao ter chegado a essa conclusão por meio de minhas próprias reflexões, foi uma grata surpresa quando descobri que outros pesquisadores convergiram para o mesmo termo. Ver, por exemplo, o já citado trabalho de Porto e Schmiedecke (2015).
} 
do conhecimento científico. Esse é apenas um exemplo ${ }^{14}{ }^{15}$, já com quase vinte anos de existência, de que a academia tem, de fato, dedicado-se a perscrutar e a aproximar o estudo da Natureza da Ciência com a sua aplicação ao ensino e à divulgação científica.

Ainda assim, devido principalmente, conforme creio, à falta de preparo filosófico, esses conceitos continuam sendo mal ensinados e, por isso mesmo, acabam servindo de combustível para alimentar as distorções já citadas. Dediquei-me ao trabalho de sintetizar esses conceitos, com base no que eles realmente significam (o que não quer dizer uma resposta única: como já comentado, o significado real é o de múltiplas visões e a ausência de consenso), em contrapartida a como eles são normalmente ensinados e divulgados. É preciso lembrar que, apesar da ausência de respostas definitivas para as principais questões que serão levantadas, precisamos nos arriscar a respondê-las. Dizem Bagdonas e Silva (2013, p. 216):

"Ainda que haja muitos opositores à noção de uma única natureza da ciência no âmbito das discussões epistemológicas, é possível derivar alguns pontos de concordância entre filósofos, historiadores e pesquisadores do ensino de ciências e apresentar alguns tópicos considerados mais relevantes para o ensino."

Somos professores e divulgadores de Ciência; espera-se de nós que saibamos o que é Ciência e como ela funciona. E se não há consenso, mas, sim, várias visões possíveis, então que a nossa tarefa seja justamente ensinar não um consenso que não existe (e esse é, talvez, o principal erro dos divulgadores e professores), mas sim a multiplicidade de respostas e abordagens possíveis. Comecemos, então, com o

\footnotetext{
${ }^{14}$ Uma análise sobre a crescente presença de artigos tratando da importância da Natureza da Ciência na educação científica pode ser encontrada em Vilas Boas et al. (2013).

${ }^{15}$ Esses pontos levantados por Lederman formam, em modesta medida, um consenso acerca do que é a Natureza da Ciência. Investigações sobre tal consenso também podem ser encontradas em McComas, Almazroa e Clough (1998), como reforçado por Bagdonas, Zanetic e Gurgel (2014). Porém, ainda há discussões em aberto, incluindo duras críticas a alguns desses pontos (Cardoso et al., 2015). Eu mesmo, no presente trabalho, não adoto completamente a posição, especialmente do que tange os pontos (a) e (b): defenderei, mais adiante, que o que caracteriza a Ciência não é o empirismo, mas o seu corpo teórico (que é mais do que um simples "guia do conhecimento científico", como afirmado no ponto [d]), assim como defenderei que não há distinção essencial entre leis e teorias. Henrique (2011), Noronha (2014) e Bagdonas (2015) também trataram do tema da falta de consenso no conteúdo da Natureza da Ciência e em como concebê-la.
} 
Critério de Popper, um dos pilares que sustentam e alimentam o problema em questão.

\section{1 - O Problema da Demarcação e a Solução de Popper}

O Problema da Demarcação, ou "Problema de Kant", tal como chamado por Popper (2013, p. 35), foi incisivamente atacado pelo austríaco, no que resultou em seu famoso Critério de Demarcação: uma ideia é científica se for falseável. Isso quer dizer que ela será considerada científica se for concebível algum experimento ou observação capaz de prová-la falsa. Esse experimento ou observação devem ser tão rigorosos quanto possíveis, assim como serem reprodutíveis por experimentadores independentes. Caso o experimento seja realizado e este não for capaz de falsear a lei/hipótese/teoria, a mesma lei/hipótese/teoria será vista como corroborada pelo experimento e deverá ser guardada pelo cientista, até que novos experimentos venham colocá-la à prova novamente no futuro.

A análise do Critério de Popper ocupará grande parte desse primeiro capítulo, uma vez que é, conforme constatado, um dos conceitos filosóficos mais citados por divulgadores da Ciência contemporâneos, tema que ampliarei com exemplos reais no Capítulo III. Antes disso, porém, faz-se necessário um comentário mais geral sobre o que é Ciência e como ela é vista através do olhar do leigo e do praticante.

Em seu aspecto mais geral, a ciência (a qual irei me referir com "c" minúsculo) pode ser vista como todo campo do conhecimento humano. Conhecer algo é, nesse caso, sinônimo de "tomar ciência" desse mesmo algo. Sob esse ponto de vista, a História, a Literatura, a Sapataria, a Teologia, a Culinária etc. seriam todas consideradas ciências, uma vez que todas compartilham a propriedade de referiremse a campos de conhecimento humano específicos. É fácil perceber que essa definição não diz muito: é elástica o suficiente para abarcar praticamente qualquer coisa, independentemente de seus métodos de pesquisa particulares. (Isso para as áreas que possuem "métodos" ou mesmo que estejam preocupadas com "pesquisa", independentemente do significado que esses termos possam assumir.)

Para os filósofos da Ciência, a exemplo do próprio Popper e, antes dele, Comte 
e Kant, o conceito de Ciência costuma ser muito mais restrito do que abarcar indistintamente todas as áreas de conhecimento: trata apenas do que tradicionalmente se intitulou Ciência Empírica ${ }^{16}$. Aqui, nos deparamos com nova dificuldade: a de definir "empírico". Essa dificuldade corresponde exatamente ao Problema da Demarcação. Como definido por Popper, uma lei, teoria ou hipótese, ou até mesmo uma simples proposição, será considerada empírica e, portanto, científica (no sentido restrito aqui explicado) se ela for falseável via experimentos e/ou observações (i.e., por via empírica). Já a "missão do cientista" é definida como a "de buscar leis que o habilitem a deduzir previsões" (Popper, 2013, p. 270). Certamente mais elaborada quando comparada à visão de um leigo completamente desinformado, essa descrição do trabalho científico é uma síntese que amplamente condiciona a visão que os próprios cientistas têm de seu trabalho, e que acaba sendo propagada pelos professores e divulgadores de Ciência, terminando por atingir o público leigo que tem acesso e/ou interesse nesse tipo de conteúdo.

Porém, como buscarei demonstrar, apoiado na crítica de Kuhn e de outros, tanto o Critério de Demarcação quanto essa descrição da atividade científica são simplificações demasiado grosseiras da realidade, grandemente idealizados pelos divulgadores de Ciência ${ }^{17}$ e pouco ou nada aplicados na prática. A conclusão que irei chegar, após longa argumentação, não é a de que o Critério de Demarcação seja "ruim", "inútil" ou "errado" (pois não parece de forma alguma ser esse o caso), mas, sim, que ele é essencialmente limitado pela própria natureza do empreendimento científico e pelo que a história da Ciência mostra ser o modus operandi dos cientistas. Isso implica em ensiná-lo como sendo uma visão possível do empreendimento científico, mas longe de ser a única e completa descrição desse mesmo empreendimento.

Vejamos o que o próprio Popper diz a respeito da dificuldade em se definir o que é Ciência (os itálicos são meus): "Minhas dúvidas aumentam quando me dou conta de que será sempre questão de decisão ou de convenção saber o que deve ser denominado 'científico' e quem deve ser chamado 'cientista'" (2013, p. 55). Nota-se

\footnotetext{
${ }^{16}$ O termo mais popular utilizado para substituir o termo quase esotérico "Empírico" é o termo, decerto muito mais familiar e, talvez, mais poético, "Naturais". Assim, as Ciências Empíricas correspondem às Ciências Naturais, que atualmente englobam a Física, a Química, a Biologia, a Geologia, a Astronomia e todas as disciplinas derivadas dessas primeiras.

17 No Capítulo III trago exemplos concretos de como o Critério de Demarcação é tratado em mídias de divulgação recentes no Brasil.
} 
algo nessa citação, uma informação frequentemente ignorada quando o Critério de Demarcação é citado por divulgadores: todos os esforços anteriores a Popper por parte dos filósofos da Ciência em demarcar de forma absoluta e definitiva o que é e o que não é Ciência de forma objetiva parecem ter falhado; e, por isso mesmo, restou a Popper propor uma "convenção" que cumprisse a tarefa ${ }^{18}$. Essa convenção não é uma convenção qualquer, mas que possui um caráter específico; é uma decisão metodológica, tal como por ele explicado (2013, p. 56):

"Assim como o Xadrez pode ser definido em função de regras que the são próprias, a Ciência pode ser definida por meio de regras metodológicas. Cabe proceder ao estabelecimento dessas regras de maneira sistemática. Coloca-se, de início, uma regra suprema, que serve como uma espécie de norma para decidir o propósito das demais regras e que é, por isso, uma regra de tipo superior. É a regra que afirma que as demais regras do processo científico devem ser elaboradas de maneira a não proteger contra o falseamento qualquer enunciado científico."

Ele conclui (p. 57) com a afirmação um tanto contundente: "o único motivo que tenho para propor meu critério de demarcação é a de ele ser proveitoso: com seu auxílio, muitas questões podem ser esclarecidas e explicadas". O Critério de Demarcação (o qual chamarei daqui em diante abreviadamente de "Critério") não foi bem aceito por todos os estudiosos contemporâneos a Popper (alguns, porém, incluindo Einstein [Popper, 2013, p. 525] estiveram de acordo o Critério, ainda que possa ser questionado o real impacto de sua adoção na prática científica desses que concordaram). Veremos mais adiante as diversas críticas que o Critério sofreu, especialmente as realizadas por Kuhn. Porém, será necessário antes esmiuçar as implicações que o Critério traz consigo, tanto em sua própria definição quanto em relação ao que Popper objetivara com a sua implementação.

\footnotetext{
${ }^{18}$ Em outras palavras, a Ciência progrediu mesmo com os cientistas do passado não tendo à disposição um método absoluto para delimitar o próprio campo de atuação. $E$ isso não os impediu de progredirem e obterem sucesso em seus objetivos, mesmo considerando toda a complexidade envolvida nos intensos debates e reviravoltas ocorridos na história da Ciência. Isso, por si só, deveria ser suficiente para não superestimarmos o valor do Critério de Popper.
} 


\section{2 - Implicações do Critério de Demarcação de Popper}

Antes de tudo, é preciso esclarecer o que o Critério não é: ele não é um critério de veracidade. Um raciocínio comum a muitos leigos, e que subjaz consciente ou inconscientemente no discurso de muitos professores, cientistas e divulgadores, conforme pude verificar (exemplificarei mais adiante), é o seguinte: "Se uma teoria é considerada científica, é porque ela é falseável. E se ela é falseável - e até o momento não foi falseada - então ela é uma teoria verdadeira". Esse pensamento, o de uma teoria que é "verdadeira", tomada erroneamente como sendo uma teoria "comprovada", tem forte influência na visão popular predominante de Ciência. Vemos ela, por exemplo, em anúncios de que "produto $\mathrm{X}$ ou $\mathrm{Y}$ teve a sua eficácia cientificamente comprovada", algo que ainda denota um grande senso de credibilidade ao ser afirmado. Isso é cientificismo.

Vê-se em tal constatação a confusão que foi realizada com os conceitos de falseabilidade e veracidade: o primeiro foi desenvolvido justamente para se resolver o problema de que é impossível comprovar empiricamente, de forma absoluta e irrevogável, o que quer que seja. Utilizando o clássico exemplo dos cisnes, não se pode afirmar cientificamente que "todos os cisnes são brancos" baseando-se apenas no fato empírico de nunca (até a data em que a afirmação foi feita) ter sido observado um cisne de outra cor. Isso pelo simples motivo de que não é possível garantir que, de fato, todos os cisnes existentes foram observados, e nem que um cisne de outra cor qualquer não será descoberto no futuro (como, de fato, foram descobertos). Este problema, muito conhecido dos epistemologistas, recebeu o nome de Problema da Indução (chamado de "Problema de Hume" por Popper [2013, p. 35], por ter sido enfaticamente atacado pelo filósofo escocês David Hume).

O Problema da Indução foi atacado intensamente por muitos lógicos e epistemólogos, como Reichenbach e Keynes, os quais buscavam por todos os meios encontrar uma maneira de resolvê-lo. No caso, resolução significava encontrar uma maneira de justificar a indução. Popper, assumindo ser impossível tal tarefa, corta o Nó Górdio com seu Critério, afirmando ter resolvido o problema da indução, quando, 
mais precisamente, apenas o removeu do arsenal da metodologia científica ${ }^{19}$.

Novamente: o Critério foi proposto justamente devido à impossibilidade de comprovação de teorias, apesar de ser, conforme é defendido, perfeitamente possível prová-las falsas, desde que sejam passíveis de teste empírico. Em sentido estrito, portanto, não existem teorias cientificamente comprovadas, mas apenas teorias que, ainda, não foram falseadas. Essa sutileza, quando esquecida, acarreta uma das maiores distorções que acompanham a visão de Ciência que possuem tanto o público em geral quanto o estudioso que desconhece a filosofia por detrás do Critério: a distorção de que as teorias científicas, uma vez que são "comprovadas" (significando que são consideradas "verdadeiras"), representam um entendimento absoluto, eterno, imutável da realidade, acima de toda crítica e contestação. Ora, é evidente que não é esse o caso (uma vez que, novamente, não há algo como "teoria cientificamente comprovada"), sendo característica marcante da Ciência a sua mutabilidade através da história, revisando-se e reconstruindo-se continuamente.

Alguns divulgadores chegam a considerar que as teorias científicas possam não ser representantes dessa classe de "certezas absolutas", mas nenhum dos que investiguei (que foram, e alguns ainda são, os de maior alcance em seus trabalhos de divulgação) pareceram dispostos a aceitar que, a qualquer momento, podem ser colocadas em cheque a ideia da existência dos átomos, a ocorrência da evolução das espécies, o início do Universo com o Big Bang etc. Para eles, na prática e em seu modo de ver (e ensinar, e divulgar Ciência), esses são fatos consumados, "cientificamente comprovados", livres e acima de toda dúvida. Essa contradição entre a visão de uma Ciência dinâmica e a da existência de teorias supostamente comprovadas pode passar completamente despercebida pelo público leigo, mas acaba por estabelecer em seu imaginário uma noção incoerente da Natureza da Ciência.

\footnotetext{
${ }^{19}$ Criou-se uma caricatura do que seriam os "positivistas indutivistas", normalmente taxandoos de ingênuos (Henrique, 2011). Embora eu não me considere alinhado com praticamente nenhuma visão positivista indutivista, tampouco aceito tal caricatura; o trabalho realizado por eles é de uma profundidade e riqueza impressionantes e, conforme argumentei, a "solução" alternativa oferecida por Popper não é realmente uma solução para o problema (tal como não podemos afirmar que Alexandre Magno desatou o lendário Nó). Uma verdadeira tentativa de solução para o problema, e que foi, ao que me parece, muito mais promissora, foi realizada por Russell em seu livro Conhecimento Humano. Infelizmente, parece que é um livro ainda pouco conhecido no Brasil (sua primeira tradução para português é a da Editora UNESP [2018]), mas que vale a pena ser revisitado por aqueles que têm algum interesse no Problema da Indução e demais tópicos basilares da Teoria do Conhecimento.
} 
Não bastasse esse problema, que já é endêmico ao senso comum de Ciência (em realidade, ele acaba mesmo por fabricar esse "senso comum científico"), a confusão entre os conceitos de falseabilidade e de veracidade traz ainda o problema inverso, que pode ser traduzido pelo seguinte raciocínio: "Se uma teoria/hipótese/lei não é falseável, então não é científica e, portanto, é falsa". ${ }^{20}$ Para começar, algo assim jamais foi afirmado por Popper, o próprio autor do Critério de Falseabilidade. Tudo o que ele fez foi separar o que é Ciência Empírica do que não é, de acordo com uma decisão metodológica e arbitrária ${ }^{21}$. Dessa maneira, se uma ideia não é falseável, então simplesmente ela não pertenceria ao domínio da Ciência Empírica ${ }^{22}$, pois não há experimento que possa ser realizado para testá-la. Mas, ora, nem todas as ideias possuem essa "natureza empírica" — essa "natureza de testabilidade" - e mesmo assim algumas são definitivamente verdadeiras. Desconsiderar isso seria o mesmo que dizer que todos os campos do conhecimento, com exceção das Ciências Empíricas $^{23}$, são falsos. Poderíamos dizer que, de acordo com essa perigosa afirmação, toda a Filosofia, a História e mais um sem-número de áreas do conhecimento que adotam outros métodos que não o empírico para realizarem seus programas de pesquisa são inválidos, ou inferiores, a priori. Talvez o leitor se pergunte: "Mas quem iria afirmar que um campo de conhecimento como a Filosofia é inválido ou inferior?". A resposta é: o falecido Stephen Hawking, um dos mais conhecidos cientistas e divulgadores de Ciência das últimas décadas! Em suas palavras, no livro best seller O Grande Projeto, a "Filosofia está morta!"24. Mas não só ele: em geral, cientistas da atualidade não possuem nem a mais básica formação filosófica ${ }^{25}$, mantendo desdém ou até mesmo desprezo declarado por ela. Tratarei do

20 Ao meu ver, este problema é muito mais grave que o anterior. Confundir uma ideia "científica" com uma ideia "verdadeira" é ingênuo, mas confundir uma ideia "não-científica" com uma ideia "falsa" pode ser verdadeiramente perigoso e fonte de inúmeros e graves erros. Ver parágrafos seguintes.

${ }^{21}$ Esse ponto é facilmente esquecido ou omitido quando se fala do Critério: é sempre necessário lembrar que ele é apenas um entre os critérios possíveis.

22 Não concordo com isso. Em breve argumentarei que as ditas "Ciências Empíricas" estão repletas de afirmações não-falseáveis, e nem por isso são ideias "menos científicas".

${ }^{23}$ Mais à frente, argumento que mesmo as Ciências Empíricas estão repletas de ideias nãofalseáveis, e nem por isso são consideradas "não-científicas".

${ }^{24}$ A afirmação de Hawking, assim como as devidas referências ao seu livro, serão comentadas mais adiante neste trabalho.

${ }^{25}$ É evidente que há cientistas que se interessam por filosofia. Aqui me refiro ao contexto geral da formação acadêmica dos cursos de Bacharelado, os quais carecem quase que por completo de disciplinas filosóficas. Assim, os cientistas que possuem alguma formação 
assunto mais adiante.

Sobre a relação entre "empírico/científico" e "verdadeiro/falso", o exemplo, tão simples quanto claro, dado por Popper (2013, p. 42), deveria ser suficiente para resolver o equívoco:

"[...] deve ser possível refutar, pela experiência, um sistema científico empírico. Assim, o enunciado "Choverá ou não choverá aqui, amanhã", não será considerado empírico [i.e., "científico"], simplesmente porque não admite refutação, ao passo que será considerado empírico o enunciado 'Choverá aqui, amanhã'."

O primeiro enunciado, apesar de não ser considerado empírico ou científico pelo Critério é, para todos os efeitos, tão certo quanto um enunciado pode ser (ou seja, podemos afirmar sem risco de erro que amanhã irá chover ou não irá chover aqui - consequência do princípio lógico do Terceiro Excluído, uma vez que tratamos de uma divisão dicotômica). O segundo enunciado, por ter a possibilidade de estar errado (ou seja, de ser falseável via verificação empírica que ocorreria no dia seguinte) é, por isso mesmo, considerado empírico ou científico. Aqui vemos que há a possibilidade de dois tipos de ideias não falseáveis (ou não científicas, de acordo com Popper): (1) aquelas que não são falseáveis por não podermos, com os recursos disponíveis atualmente, dizer nada empírico acerca de sua veracidade ou falsidade (exemplos: "Existe vida inteligente fora do planeta Terra", "Deus existe" ou ainda "Deus não existe"), e (2) aquelas que não são falseáveis simplesmente por serem absolutamente certas e estarem acima de qualquer dúvida, justamente por serem coletivamente exaustivas (exemplo: "Choverá ou não choverá aqui, amanhã")26, permanecendo numa zona em que testes são inócuos e redundantes. No primeiro caso, a afirmação pode ou não ser verdadeira (com o Critério apenas dizendo que a resposta não está ao alcance do experimento - do teste empírico); no segundo caso, a afirmação é absolutamente verdadeira e dispensa a necessidade de qualquer teste empírico; em ambos os casos, a "não-cientificidade" de uma ideia não a faz automaticamente falsa (no segundo exemplo, em particular, a "não-cientificidade" —

filosófica quase sempre a obtiveram por interesses particulares, e não por terem recebido uma formação oficial durante a sua graduação.

26 Que os céticos radicais venham a questionar a afirmação de que existem "verdades absolutas" é algo que não levarei em conta; peço que o leitor faça essa concessão, ao menos ao nível de compreensão que o texto pede. 
o fato de ser impossível de ela ser provada falsa - decorre justamente da absoluta certeza de que a ideia é lógica e necessariamente verdadeira e imune a testes comprobatórios e/ou falseadores). Mesmo a Metafísica, altamente desprestigiada desde o surgimento do Positivismo, e que era de fato o principal alvo da demarcação, não poderia simplesmente ser descartada (como de fato não o foi por Popper) por "não ser falseável". (Discorrerei especificamente sobre a Metafísica na seção 1.4.)

Tudo isso foi dito para enfatizar o cuidado que o professor e o divulgador devem ter para com seu público quando afirmam que tal ou qual ideia "não é científica". O cuidado é para que, com essa afirmação, não se pretenda dizer mais do que ela realmente diz: que tal ideia simplesmente foge do campo da Ciência Empírica, e deve ser estudada por outro tipo de profissional através de outros métodos que não o empírico. Afirmar para um grupo de estudantes ou de leigos interessados em Ciência que uma ideia "não científica" é uma ideia falsa, ou simplesmente sem sentido, é, no mínimo, uma demonstração de profunda ignorância - para não dizer desonestidade intelectual, com efeitos nocivos para a própria Ciência, uma vez que tal afirmação é um perfeito exemplo das distorções que venho indicando desde a introdução desta dissertação. Por outro lado, se uma ideia já foi repetidamente falseada por procedimentos empíricos, ela deveria ser considerada enfaticamente como falsa (ao menos no nível de precisão alcançado pelos experimentos realizados). A realidade (em específico, o estudo histórico) mostra, porém, que muitas ideias efetivamente falseadas continuam a ser defendidas, não só no âmbito da pseudociência como da própria Ciência, constituindo um dos principais pontos onde o Critério falha: ele depende de certos fatores estritamente humanos, psicológicos, tal como a aceitação honesta e humilde de que a ideia defendida até o momento estava equivocada. $O$ próprio Popper afirmou que tal objeção ao critério é séria (1993, p. 43, [ ] meus):

"Caberia afirmar que, admitida embora a assimetria [entre verificabilidade e falseabilidade], continua a ser impossível, por motivos diversos, que todo sistema teorético sempre possa ser conclusivamente falseado. Isto porque sempre é viável encontrar alguma forma de evitar a falsificação, introduzindo, por exemplo, uma hipótese auxiliar ad hoc ou alterando, ad hoc, uma definição. É mesmo possível, sem incoerência lógica, adotar a posição de simplesmente recusar o reconhecimento a qualquer experiência falseadora. Por certo, habitualmente, os cientistas não procedem dessa maneira [!], mas, do ponto de vista lógico, tal processo é possível e 
esse fato, poder-se-ia asseverar, torna dúbio o valor lógico do critério de demarcação por mim proposto, para dizer o mínimo."

O erro cometido por Popper foi a afirmação que assinalei com [!]: é exatamente assim, protegendo teorias contra falseamentos, que os cientistas atuam normalmente. A história da Ciência pode ser vista, sob determinada abordagem, como a história da resistência à mudança, em que ideias originais sempre tiveram dificuldades ao tentarem se inserir, e que as ideias já aceitas continuam a sê-lo mesmo depois de, supostamente, terem sido falseadas. Em outro trecho (ibid., p. 85), afirma Popper:

"Nós, e aqueles que partilham de nossa posição, esperamos efetuar descobertas novas e esperamos ser auxiliados, nesse trabalho, por um sistema científico que acaba de aparecer. Teremos, por isso, o maior interesse pelo experimento falseador. Saudá-lo-emos como um êxito, por ele ter aberto horizontes novos num mundo de experiências novas. Saudá-loemos ainda que essas novas experiências nos forneçam argumentos novos contra as nossas mais recentes teorias."

Considero admirável a atitude de honestidade intelectual de Popper e compartilho da mesma. Porém, a realidade da prática científica é outra. Como dito, o padrão é a defesa, e não o ataque de teorias. Esse é um dos pontos da argumentação de Kuhn ao criticar o Critério de Demarcação de Popper, conforme veremos a seguir.

\section{3 - Críticas de Kuhn ao Critério de Falseabilidade de Popper}

O Critério passou por diversas críticas ao longo do século XX. As mais contundentes provavelmente são provenientes dos argumentos que Kuhn apresentou n'A Estrutura, que serão a seguir analisados ${ }^{27}$. Mas, antes, é preciso fazer algumas considerações, as quais oferecerão um panorama mais claro do que é pretendido dizer.

Para início de discussão, concordemos com o fato de que, apesar da imensa dificuldade pela qual passaram os filósofos da Ciência desde Kant, a Ciência

${ }^{27}$ Existem também críticas de peso mais recentes, tal como a feita por Agassi (1991). Ver referências. 
desenvolveu-se majoritariamente à parte desses debates. Isso não quer dizer que os cientistas não tinham interesse pela questão. Muito pelo contrário: exemplos de cientistas-filósofos, como Galileu, Newton e Leibniz, abundam na história. O que quero dizer é que os cientistas do passado fizeram Ciência mesmo sem ter à disposição uma definição, uma demarcação nítida, definitiva e absoluta, entre o que é e o que não é Ciência. É como se a Ciência pudesse seguir seu rumo, desenvolvendo-se e progredindo, sem a necessidade de tal definição absoluta. E isso dá origem a uma série de questionamentos: (1) será que o "Problema de Kant" é de fato um problema? Ao menos para os cientistas praticantes, aparentemente não. Mas, então, (2) onde residiria o valor do Critério, se ele foi justamente proposto para resolver um problema que, aparentemente, não significou uma barreira para os cientistas do passado? Ou (3) será que, de fato, tal barreira existiu, quer os cientistas se importassem ou não com ela, e o Critério poderia ter permitido um avanço mais veloz na Ciência? E, agora que temos disponível o Critério, (4) estaria ele de fato sendo aplicado pelos cientistas e auxiliando, de alguma forma, no progresso da Ciência? O Critério, afinal, (5) é uma resposta satisfatória ao Problema, ou seria apenas a solução "menos pior" da qual temos disponibilidade no presente momento? Muitas dessas questões exigem um aprofundamento que foge do alcance do presente trabalho, mas algo pode certamente ser dito acerca delas. Vamos começar pela (1).

Como já parcialmente respondido, parece que determinar o que é Ciência, e o que não é, é uma preocupação que não faz parte do cotidiano do cientista. Em realidade, tal questionamento é essencial mais ao filósofo do que ao cientista. Este último sabe o que é Ciência pela prática e pela formação que obteve, e mesmo que tivesse dificuldade em expressar-se com exatidão acerca do que ela, a Ciência, de fato é, ele poderia responder através de suas ações, pertencentes à sua rotina diária de trabalho. Porém, por mais difícil que seja definir a Ciência, a tarefa precisa ser feita, visto que uma correta e eficiente divulgação e educação científica passa por apresentar essa resposta ao grande público, de forma tão compreensível e realista quanto possível. E, como já dito, a resposta não pode consistir em um falso consenso (como o falso consenso de que o Critério é a única, ou a melhor, forma de definir o que é Ciência).

Com relação ao ponto (2), o assunto fica mais delicado. Embora o Critério seja algumas vezes divulgado como definitivo e seguro, dados da história da Ciência, como 
demonstrou Kuhn, parecem sugerir o oposto. Em realidade, sob muitos aspectos, o Critério parece estéril, tratando-se mais de um ideal inatingível e não-compatível com a natureza humana da Ciência. Em casos ainda mais graves, tanto uma análise histórica quanto uma análise epistemológica parecem sugerir que, caso o Critério tivesse sido utilizado no passado, ou mesmo se fosse de fato utilizado no presente, toda a Ciência ruiria - o que já responde à pergunta (3): o Critério, na prática, não está sendo aplicado rigorosamente pelos cientistas e, por conseguinte, não está auxiliando — ou o está em baixo grau — o progresso da Ciência.

Vamos finalmente à análise que Kuhn faz da questão. A citação a seguir (2012, p. 80) servirá como bom ponto de partida:

"Para ser aceita como paradigma ${ }^{28}$, uma teoria deve parecer melhor que suas competidoras, mas não precisa (e de fato isso nunca acontece) explicar todos os fatos com os quais pode ser confrontada."

Até o ponto em que diz que "uma teoria deve parecer melhor que suas competidoras", Kuhn concorda quase integralmente com Popper (ver, por exemplo, Popper, 2013, p. 44), salvo pela palavra "parecer": para Popper, teorias poderiam ser analisadas objetivamente através da lógica, de forma que seria evidente qual delas seria a melhor (em suas palavras, a teoria de "maior conteúdo empírico" e, portanto, "a teoria falseável em maior grau" [ver Popper, 2013, capítulo VI, seção 35; e também capítulo X, seção 83]). Indo em direção oposta, ao escolher a palavra "parecer", Kuhn sugere sutilmente que a escolha entre teorias é, ao menos parcialmente, subjetiva. Popper poderia até não negar essa ideia completamente, pois afirma que é preferível, mas não absolutamente obrigatória, a escolha de uma teoria mais bem corroborada do que suas concorrentes (2013, p. 309), mas Kuhn vai mais além e não faz referência enfática a critérios objetivos e lógicos como tentado por Popper. Porém, o aspecto mais instigante da afirmação de Kuhn está na segunda parte. Afinal, se uma teoria nunca explica todos os fatos com as quais pode ser confrontada, ela estaria, já aí, falseada por esses mesmos fatos. É preciso tomar cuidado com a sutileza dos termos utilizados: não estamos falando aqui da trivialidade de uma teoria biológica não poder ser confrontada com fenômenos cosmológicos ou relativísticos. Uma teoria dessa espécie não tem a obrigação, e nem mesmo pretende, explicar fenômenos que não

${ }^{28} \mathrm{O}$ termo paradigma, consolidado e popularizado por Kuhn, bem conhecido de quem estuda Filosofia da Ciência, será visto em detalhes mais adiante. 
estão em seu território ${ }^{29}$. O que Kuhn está dizendo claramente é que uma teoria não é capaz sequer de explicar todos os fenômenos que, efetivamente, pretende explicar, e isso é radicalmente diferente! Isso também não diz respeito à incompletude de uma teoria; que uma teoria não possa explicar todos os fenômenos, é uma verdade trivial (e isso sem entrar no mérito dos Teoremas da Incompletude de Gödel).

O que está sendo ressaltado é a incapacidade de uma teoria explicar todos os fenômenos que ela mesma se propõe a explicar. Como ficará claro com posteriores argumentações, é justamente esse caráter deficiente de uma teoria que dá aos cientistas trabalho a ser feito (no caso, buscar por todos os meios adequar essas teorias aos fatos por ela ainda não explicados — ou, mais precisamente, "adequar os fatos às teorias" [ver referência à frente]), e o que, em última análise, confere a qualidade dinâmica à Ciência. Tal dinamismo é derivado da possibilidade de uma teoria, inerentemente incompleta por sua própria natureza, ser substituída por outra menos incompleta ou, minimamente, mais de acordo com as respostas que os cientistas estão buscando. Porém, nenhuma teoria nova surgiria se as antigas fossem absolutamente completas e livres de fatos que as contradigam. De fato, a análise de Kuhn demonstra que toda teoria, com sua inerente incompatibilidade com muitos fatos, já carrega a semente da sua própria refutação (mais uma vez, [e isso nem sempre é compreendido]: toda teoria já nasce, deste ponto de vista, falseada ${ }^{30}$ ).

${ }^{29}$ Apesar de óbvio, deixo registrada essa frase como precaução a possíveis mal entendidos com respeito ao que pretendo dizer.

${ }^{30}$ Apesar de essa afirmação de que "toda teoria já nasce falseada" poder ser desprendida da argumentação de Kuhn, ele não foi tão incisivo quanto estou sendo agora. Também desconheço outros autores que tenham abordado a questão de maneira tão franca. Confesso que, para mim, foi um verdadeiro choque encarar esse fato na primeira vez que me dei conta dele. Que cientista ou professor afirmaria que todas as nossas teorias já estão falseadas? De tanto meditar sobre o assunto, terminei por sintetizar um argumento que, talvez, ajude aqueles que estão buscando por compreender a ousada afirmação. $O$ argumento é o seguinte: toda teoria é perfeita ou é imperfeita. Se é perfeita, então todos e cada um de seus enunciados encontram uma perfeita correspondência com um fato da Natureza, de forma que a teoria explica de forma precisa tais fatos, e que não há nenhum fato que possa contrariá-la. Nesse caso, a teoria seria perfeitamente imune a qualquer falseamento, e poderíamos dizer que, de fato, chegamos a um conhecimento final acerca da Natureza. Porém, caso a teoria seja imperfeita, então necessariamente há pelo menos um fato da Natureza que contradiga falseie - ao menos um dos enunciados da teoria. E isso, é evidente, independe de já conhecermos ou não tal fato: se a teoria é imperfeita, é uma necessidade lógica que ao menos um de seus enunciados não encontrará corroboração na realidade, mas a sua negação. Ora, não há - ou há bem poucos - motivos para crermos que qualquer uma de nossas teorias seja perfeita. Somos, portanto, inclinados a assumir que todas as nossas teorias são imperfeitas, e que há, aqui e agora, pelo menos um fato natural que a falseie, independentemente de nós já termos encontrado ou não tal fato. $\mathrm{O}$ exemplo que dou nos 
Como exemplo histórico, podemos pensar na Teoria da Gravitação Universal de Newton: ela se propunha a explicar as órbitas dos planetas, mas desde o seu nascimento ela já fracassava em explicar a órbita anômala de Mercúrio (independentemente de se esse fato já era conhecido ou não quando a teoria foi proposta). Assim, tal teoria já nasceu falseada por um fenômeno que, desde o seu princípio, tinha como meta explicar. Apesar de ser um exemplo histórico pontual, ela chama a atenção por ser considerada uma das grandes epítomes da Ciência moderna (e não uma teoria qualquer que pudesse ser considerada "secundária"). E, por fim, exemplos análogos podem ser encontrados para cada teoria proposta em toda a história da Ciência.

Mas se, como dito, todas as teorias já estão falseadas pelos mesmos fatos que pretendem explicar, elas, de acordo com Popper, deveriam ser abandonadas - o que resultaria no colapso total da Ciência, o que obviamente não ocorre. Só podemos concluir disso que (a) o Critério não está de facto sendo rigorosamente aplicado e que, portanto, (b) não corresponde à realidade do trabalho científico. Como citado na seção anterior, Popper afirma que a "missão do cientista" é definida como a "de buscar leis que o habilitem a deduzir previsões" (2013, p. 270). Em contrapartida, sobre a tarefa do cientista, diz Kuhn (2012, pp. 88-9):

"A maioria dos cientistas, durante toda a sua carreira, ocupa-se com operações de acabamento. (...) esse empreendimento parece ser uma tentativa de forçar a natureza a encaixar-se dentro dos limites preestabelecidos e relativamente inflexíveis fornecidos pelos paradigmas. A ciência normal ${ }^{31}$ não tem como objetivo trazer à tona novas espécies de fenômenos; na verdade, aqueles que não se ajustam aos limites do paradigma frequentemente nem são vistos. Os cientistas também não estão constantemente procurando inventar novas teorias; frequentemente mostram-se intolerantes com aquelas inventadas por outros. Em vez disso, a pesquisa científica normal está dirigida para a articulação daqueles fenômenos e teorias já fornecidos pelo paradigma."

Certamente que "há cientistas que buscam leis que os habilitaram a deduzir previsões", mas essa não é a realidade da maioria dos cientistas em atividade. Os

parágrafos seguintes acerca da Gravitação Universal serve como modelo para o presente argumento. Mais à frente, também problematizo o conceito de "fato" e também o "fato" de que todo falseamento é apenas parcial.

31 Termo explicado mais adiante. 
que buscaram, e de fato encontraram (e, por isso mesmo, são os grandes nomes que figuram nas cronologias das "descobertas científicas"), o fizeram mais por obrigação imposta pela situação de dúvida vigente do que por um padrão de sua profissão. Quem lê um livro popular de História da Ciência (como "Uma Breve História da Ciência" de William Bynum ou "O Livro da Ciência" da Editora Globo) apenas vê uma cronologia dos "grandes nomes da Ciência", aqueles que "buscaram leis" e que foram bem-sucedidos em delas "deduzir previsões". Todo o trabalho árduo das centenas, milhares ou ainda mais cientistas contemporâneos a esses luminares é simplesmente ignorado, pois a sua ocupação era diferente: trata-se das operações de acabamento da citação de Kuhn acima referida.

O argumento de Kuhn, embasado em sua visão particular da história da Ciência ${ }^{32}$, nos leva a concluir que nenhum cientista buscará inventar novas teorias, a menos que a situação de "incapacidade de explicação" das teorias vigentes seja sumamente intolerável (tal como o foi, por exemplo, a "catástrofe do ultravioleta" para os físicos da virada do século XIX para o XX). Como tal "incapacidade de explicação" das teorias é permanente (ou seja, todas elas estão automaticamente falseadas), seguir o critério de Popper em conjunção com sua visão de "missão do cientista" resultaria em uma paralisia total do empreendimento científico: todos os cientistas estariam o tempo todo buscando criar novas teorias que explicassem as lacunas deixadas pelas teorias vigentes (ao invés de estarem buscando articular e encontrar aplicações relevantes dessas mesmas teorias); como essas novas teorias também teriam suas próprias lacunas, o processo seguiria ad infinitum, em uma permanente e inconclusiva crise científica ${ }^{33}$. É por isso que os cientistas comuns toleram a dita "incapacidade de explicação", com a plena esperança de conseguir resolver tais problemas em um futuro próximo (problemas que Kuhn chamava de "quebra-cabeças" [2012, capítulo 3]) e está de acordo com a visão de Laudan de Ciência como uma técnica de resolver problemas (Laudan, 1993). Alguns desses problemas serão de fato resolvidos, o que renderá bons artigos em revistas de divulgação e boas teses de doutorado, mas outros apenas o serão quando uma teoria completamente nova entrar em jogo em substituição à, agora ultrapassada, teoria anterior.

\footnotetext{
${ }^{32}$ Enfatizo que se trata de uma visão particular de Kuhn uma vez que outras "histórias da Ciência" são possíveis.

${ }^{33}$ O termo "crise" é fundamental para a compreensão de como a Ciência progride, e será visto em pormenores no Capítulo II.
} 
Um cientista não pode simplesmente abandonar uma teoria quando algum experimento "a falsear". O próprio Popper sabia disso, quando admite em seu artigo (ver Popper, 1997) que a Teoria da Evolução das Espécies, baseada exclusivamente na Seleção Natural, foi falseada pelos pavões que são selecionados não pela "seleção natural das condições ambientes e de competição pela sobrevivência", mas pela seleção sexual realizada pelas fêmeas dessa mesma espécie, quando escolhem os machos mais "belos" para acasalar. Esse falseamento não constitui motivo para se abandonar a Teoria da Evolução (causada exclusivamente por Seleção Natural); primeiro, porque seu poder explanatório continua vasto apesar de não abranger esse caso em particular e, segundo, por não haver teoria concorrente à altura, com maior poder explanatório e de predição, além de abrangência, precisão e universalidade.

Além disso, é conveniente agora lembrar o seguinte trecho (Popper, 2013, p. 52):

"Em verdade, jamais pode ser apresentada uma refutação conclusiva de certa teoria, pois sempre será possível afirmar que os resultados experimentais não são dignos de crédito ou que as discrepâncias que se afirma existirem entre os resultados experimentais e a teoria são apenas aparentes e desaparecerão com o avanço de nossa compreensão."

Isso nos leva de volta à questão da divulgação científica. Como veremos, os divulgadores costumam comunicar ao público a visão de que uma teoria falseada deve ser abandonada pelos cientistas. Mais grave ainda: dizem que realmente foi assim que a Ciência progrediu. Isso, conforme tudo o que foi argumentado, é impossível: cientistas não simplesmente abandonam teorias que tenham sido falseadas; e se resolvessem fazê-lo de forma rigorosa, seriam obrigados a abandonar absolutamente todas as teorias atualmente aceitas (e também nunca poderiam aceitar novas teorias, pois tanto as teorias atualmente aceitas como qualquer teoria que venha a ser elaborada no futuro já estão naturalmente falseadas pelos fenômenos que, mesmo pretendendo, não são capazes de explicar).

Popper estava ciente ainda de uma outra falha importante em seu Critério, uma que já apontei no último parágrafo da seção anterior. Trata-se da atitude, por ele considerada não-científica, de tentar blindar uma teoria qualquer contra o falseamento via adição de hipóteses ad hoc.

Não é possível falsear completamente nenhuma teoria. Todo falseamento é pontual. Nem mesmo a afirmação aristotélica de que "um corpo mais massivo cai mais 
velozmente que um corpo menos massivo" pode ser completamente falseado: a afirmação é verdadeira dependendo dos objetos escolhidos, das condições iniciais e das condições ambientes. É possível um sem-número de experimentos que corroborariam a afirmação aristotélica. Ao pegarmos duas folhas de papel idênticas, amassarmos uma delas em formato de bola, e soltarmos ambas ao mesmo tempo e da mesma altura em uma sala comum, observaremos que a bola cairá mais velozmente que a folha aberta. Isso falsearia a teoria ${ }^{34}$ de Aristóteles: as duas folhas deveriam cair ao mesmo tempo, uma vez que possuem a mesma massa. Porém, em realidade, isso apenas falseia um aspecto da teoria: a de que ela não é válida quando se há ar no ambiente, ou ainda que não é válida para conformações diferentes do objeto, dentre muitas outras abordagens possíveis. O ponto é que isso não seria motivo para abandonar toda a teoria, mas sim que ela necessita de uma revisão ou complemento nesse determinado aspecto. Mas não é preciso ir tão longe: soltar um livro e uma bola de papel, ao mesmo tempo e da mesma altura (se não for muito elevada e se o local estiver livre de ventos) resultará em uma queda de mesma duração e com mesma velocidade, ainda que haja uma grande diferença de massa entre eles. Um fenômeno tão simples como esse não pode ter passado despercebido pelos olhos de todos os sábios da antiguidade compreendidos entre Aristóteles e Galileu. Acontece que, até esse último, aparentemente ninguém sentiu a necessidade de abandonar toda uma explicação, certamente válida para muitos casos, por causa de uma observação referente a um caso em particular. Basta fazer uma pequena correção na teoria, ou adicionar uma hipótese ad hoc, e a teoria estaria a salvo. Efetivamente, não só o aristotelismo, mas toda teoria científica alguma vez adotada, já passou por correções, "salvamentos" e "blindagens ad hoc" dessa espécie (procedimentos, vale lembrar, condenados por Popper). E, embora usar esse tipo de argumentação possa parecer estranho à primeira vista, especialmente ao olhar cientificista ${ }^{35}$, é exatamente o que ocorre diariamente no mundo da Ciência.

Nenhuma teoria é dada simplesmente como "falseada", não importa o quanto as observações pareçam sugerir que, efetivamente, ela assim seja. Quando os astrônomos do século XIX detectaram a anomalia na precessão da órbita de Mercúrio,

\footnotetext{
${ }^{34}$ Alguns, equivocadamente, não chamariam tal ideia de "teoria". Argumentarei com relação a esse ponto em uma seção posterior.

${ }^{35}$ Em resumo, alguém que superestima a Ciência. Outros detalhes serão abordados mais adiante.
} 
foi sugerido que a massa de Vênus deveria ser maior do que o calculado na época. Uma hipótese alternativa era a da existência de outro planeta (que, inclusive, já tinha nome - Vulcano) que exercia influência gravitacional sobre Mercúrio. É notável que os cientistas sugeriram de tudo - desde a alteração da massa de um planeta [!] até a existência (no caso, quase a "criação") de um novo corpo celeste [!!!] — exceto considerar a teoria de Newton como falseada e, imediatamente, perseguir por uma substituta. Até Einstein se surpreendeu (Kuhn, 2012, p. 254) quando, no século seguinte, sua Teoria Geral da Relatividade explicou a precessão do referido planeta (explicação essa que prescindiu completamente das duas hipóteses anteriormente sugeridas), sendo que fornecer essa explicação nunca fora a motivação do cientista ao formular a sua inovadora teoria da gravitação!

Casos análogos podem ser encontrados em toda a história da Ciência, de forma quase inumerável. Quando Michelson e Morley não detectaram o "éter luminífero"36 naqueles famosos experimentos que levam os seus nomes, nenhuma teoria foi abandonada ou simplesmente dada como falsa, mas seguiu-se a esperança de que novos experimentos - ou, talvez, melhores experimentadores conseguiriam detectá-lo. Outros cientistas repetiram os experimentos, sempre com resultados negativos, e as tentativas poderiam continuar indefinidamente se não fosse o surgimento de uma nova teoria - a Relatividade Restrita - para substituir as antigas ideias mecânicas e eletrodinâmicas que baseavam-se nas supostas propriedades do éter. Valem as palavras de Kuhn (2012, p. 163): "O fracasso em alcançar uma solução desacredita somente o cientista e não a teoria".

Mais recentemente, ao longo de décadas, enquanto o bóson de Higgs e as

\footnotetext{
${ }^{36}$ Em realidade, eles não estavam "tentando detectar o éter". Infelizmente, é assim que é, erroneamente e frequentemente, ensinado. A existência do éter não estava em questão - ao contrário, assumir a sua existência era essencial para o experimento que visava detectar a velocidade da Terra com relação a essa substância. Nenhuma variação foi detectada, apesar de todas as acuradas medições realizadas. Einstein resolveu o problema, não derrubando a existência do éter, mas simplesmente explicando as observações sem recorrer a ele. Esse é outro grave erro cometido no ensino e na divulgação: ninguém provou que "o éter não existe", pois, simplesmente, é impossível provar que "algo qualquer não existe". Podemos, sim, fazer a decisão epistemológica (e, portanto, filosófica e não "empírica" - seja lá o que signifique uma "decisão empírica") de não recorrer a grandezas não observáveis ou não detectáveis para explicar fenômenos do mundo natural, que foi o que Einstein fez. Outras interpretações foram fornecidas para os resultados de Michelson e Morley (como a feita por Lorentz e Poincaré, que seguiam princípios epistemológicos diferentes). Nas palavras do prof. Roberto de Andrade Martins (1998, p. 267): "Na versão de Einstein, a teoria prevê os efeitos, mas não se preocupa em apresentar uma explicação causal dos fenômenos."
} 
ondas gravitacionais permaneceram igualmente não detectadas, os cientistas não abandonaram a Teoria Quântica do Modelo Padrão ou a Relatividade Geral, mas, sim, continuaram a sua busca bilionária com fé nas previsões de ambas as teorias. Se a Relatividade Geral estivesse equivocada em prever a existência de Ondas Gravitacionais, as tentativas de detecção continuariam e nunca teríamos certeza desse equívoco (os experimentos ou os cientistas seriam vistos como falhos, mas não a teoria), pois, como nunca é demais lembrar, não é possível, por via empírica, provar definitivamente que algo "não existe".

Continua sendo difícil demarcar o que é Ciência e o que não é. Sobre isso, diz Kuhn (2012, pp. 261-2, [ ] meus):

"Percebe-se imediatamente que parte da questão [da demarcação] é inteiramente semântica. $O$ termo ciência está reservado, em grande medida, para aquelas áreas que progridem de maneira óbvia. Mais do que em qualquer outro lugar, nota-se isso claramente nos debates recorrentes sobre a cientificidade de uma ou outra ciência social contemporânea. Tais debates apresentam paralelos com os períodos pré-paradigmáticos ${ }^{37} \mathrm{em}$ áreas que atualmente são rotuladas científicas sem hesitação. O objeto ostensivo dessas discussões consiste numa definição desse termo vexatório. Por exemplo, alguns argumentam que a psicologia é uma ciência porque possui tais e tais características. Outros, ao contrário, argumentam que tais características são desnecessárias ou não são suficientes para converter esse campo de estudos numa ciência. Muitas vezes investe-se grande quantidade de energia numa discussão desse gênero, despertam-se grandes paixões, sem que o observador externo saiba por quê. Uma definição de ciência possui tal importância? Pode uma definição indicar-nos se um homem é ou não um cientista? Se é assim, por que os artistas e os cientistas naturais não se preocupam com a definição do termo? Somos inevitavelmente levados a suspeitar de que está em jogo algo mais fundamental."

De fato, como dito anteriormente, todo campo científico progrediu sem a necessidade de uma definição realmente rígida do que é e do que não é Ciência. Popper propôs a sua resposta, provavelmente a melhor proposta até a época, mas a quem ela serve? Os cientistas parecem não levá-la realmente em conta em suas pesquisas. Kuhn afirma claramente que "cientistas naturais não se preocupam com a definição do termo". Eles sabem o que é Ciência pela prática e pelo treinamento. Então

${ }^{37}$ Mais detalhes sobre o termo no Capítulo II. 
por que o Critério continua sendo divulgado como uma maneira de "definição" de Ciência? Além disso, estariam os cientistas sendo prejudicados ao tomar essa atitude de não se importar com um rigor absoluto sobre o que é Ciência? A Ciência teria algo a ganhar adotando oficialmente o Critério de Popper? Quanto mais estudo e reflito sobre o assunto, mais sou levado a concluir negativamente acerca dessa questão.

Prossegue Kuhn em sua crítica (2012, p. 160):

"Nenhum processo descoberto até agora pelo estudo histórico do desenvolvimento científico assemelha-se ao estereótipo metodológico da falsificação por meio da comparação direta com a natureza. Essa observação não significa que os cientistas não rejeitem teorias científicas ou que a experiência e a experimentação não sejam essenciais ao processo de rejeição, mas que $-\mathrm{e}$ este será um ponto central -0 juízo que leva os cientistas a rejeitarem uma teoria previamente aceita baseia-se sempre em algo mais do que essa comparação da teoria com o mundo. Decidir rejeitar um paradigma é sempre decidir simultaneamente aceitar outro e o juízo que conduz a essa decisão envolve a comparação de ambos os paradigmas com a natureza, bem como sua comparação mútua."

Se usássemos apenas o Critério de Popper para determinar o que é e o que não é Ciência, não haveria Ciência. Isso pois, na comparação com a Natureza, não há uma única teoria que sobreviva a todos os confrontamentos conhecidos. É necessário enfatizar novamente esse ponto: toda teoria já nasce falseada. Mas não podemos abandonar as nossas teorias; fazer isso seria abandonar a própria Ciência, que é, afinal, teorética (tanto quanto, ou ainda mais, é empírica, conforme discutirei mais adiante). Se uma teoria não nos atende por um lado, outra teoria, ainda que considerada superior, não nos atenderá por outro. Precisamos, pois, comparar umas com as outras, afim de escolher qual nos atende melhor. Não podemos, dessa forma, aceitar o Critério como forma de definir o que é Ciência - levando-o até o limite, nos veríamos sem nada. Kuhn já previu que sua ideia não seria bem aceita pelos defensores do Critério, e por isso adiantou (2012, p. 160) que esses defensores "conceberão numerosas articulações e modificações ad hoc de sua teoria [!], a fim de eliminar qualquer conflito aparente. Muitas das modificações e especificações relevantes já estão presentes na literatura". Aqui, Kuhn deveria estar se referindo a 
Lakatos, um filósofo da Ciência contemporâneo e assumidamente popperiano ${ }^{38}$. De fato, o Critério de Popper é fruto de uma bela argumentação lógica, mas falha ao ser confrontado com a complexa realidade da história do progresso científico.

A mais contundente crítica de Kuhn acerca da abordagem de Popper pode ser encontrada no capítulo 11 d'A Estrutura. Kuhn enfatiza que "nenhuma teoria resolve todos os quebra-cabeças com os quais se defronta em um dado momento" (2012, p. 244). Esse é provavelmente o ponto mais importante de todos: todas as teorias atuais falham em algum ponto em que, por princípio, não deveriam falhar, o que nos levaria a considerá-las falseadas. Mas não podemos fazer isso, pois "é precisamente a adequação incompleta e imperfeita entre a teoria e os dados que define, em qualquer momento, muitos dos quebra-cabeças que caracterizam a ciência normal" (ibidem). Uma outra forma de dizer isso seria: "é precisamente a adequação incompleta e imperfeita entre a teoria e os dados que dá aos cientistas algo a fazer; uma tarefa, uma missão, um objetivo."

Outro ponto essencial é o fato de que Popper deu uma excessiva importância à falsificação, negando quase que por completo a verificação (podemos ver isso claramente nos quatro primeiros capítulos d'A Lógica). Mas é claro que não podemos aceitar uma Ciência inteiramente negativa, precisamos positivamente afirmar algo e poder verificar tal afirmação. Mesmo sendo altamente crítico ao positivismo lógico, Popper não pode deixar de defender a ideia de verificação sob um outro nome: corroboração (ver o capítulo X d'A Lógica). Kuhn não deixou de notar isso e deu maior importância a esse fato de uma maneira que Popper, aparentemente, não percebeu: o falseamento de uma teoria é uma verificação ou corroboração de uma teoria concorrente (esteja ela já formulada ou não) (Kuhn, 2012, p. 245). Acrescento eu que a Ciência é impossível sem a prévia adoção de uma teoria, de forma que cada experimento está sempre falseando uma ou mais teorias e, ao mesmo tempo, afirmando outra ou outras tantas teorias. Com isso, seremos obrigados a reconhecer que o verificacionismo, embora tão criticado por ser visto como uma característica positivista, não pode ser totalmente extirpado da epistemologia da Ciência moderna. Cada fenômeno, dado ou ocorrência que os cientistas se debruçam para tentar

\footnotetext{
${ }^{38}$ Como evidência desse palpite, lembro do fato de que o próprio Lakatos organizou, em Londres (1965), debates ao estilo "popperianos versus kuhnianos", estando ativamente em contato com as ideias de ambos os filósofos. Lembrando que A Estrutura das Revoluções Científicas data de 1962.
} 
explicar e que, obstinadamente, se recusam a encaixar na teoria vigente, estão, naquele mesmo momento, verificando - ainda que parcialmente - uma outra teoria, já formulada ou não, que efetivamente os explicariam. Dessa forma, vemos ser inviável (de fato, não é assim que ocorre) uma Ciência alicerçada exclusivamente no falseamento de suas teorias. Isso seria uma exagerada simplificação metodológica, demasiadamente estreita para se adequar à realidade prática do fazer científico.

Conclusão: se aceitarmos a análise de Kuhn acerca do Critério, sem tentar blindá-lo com hipóteses ad hoc, só nos resta igualmente aceitar uma resposta negativa à questão (5): o Critério não responde satisfatoriamente o Problema da Demarcação e nem é, ao menos no nível pretendido por Popper, "útil", merecendo, ao menos, sofrer severa revisão de princípios ${ }^{39}$. No mínimo, deveríamos nos abster de ensinar e divulgar o Critério como "a" definição de Ciência.

Contudo, há uma observação que é relevante de ser feita: aceitariam os popperianos a crítica de Kuhn? Provavelmente, não. Eles certamente terão contraargumentos sobre tais críticas. E contra esses contra-argumentos, os kuhnianos também teriam as suas objeções. Isso é típico do debate filosófico. A filosofia caminhou não na direção do consenso, mas da constante ramificação do pensamento ${ }^{40}$. Não surpreende que as mais importantes questões filosóficas ainda em debate datem da Grécia antiga. Assim sendo, qual é, afinal, o ponto em questão? A resposta é simples e já foi dada: quando ensinarmos e divulgarmos a Ciência, especialmente quando estivermos tratando da importante questão filosófica acerca de qual é a sua natureza, devemos ensinar as diferentes abordagens que foram propostas ao longo do tempo, e não uma única delas como sendo a definitiva. Isso é algo que, acredito, o próprio Popper levaria em conta, pois parece convergir com a sua afirmação de que a definição de Ciência é, e sempre será, uma questão de interpretação. A abordagem popperiana e a abordagem kuhniana são duas diferentes formas de interpretar o que é Ciência. Há outras ainda - por exemplo, o enfoque na resolução de problemas de Larry Laudan. Quais e quantas abordagens ensinaremos e divulgaremos, depende de múltiplos fatores: qual o nosso objetivo, qual o nosso público-alvo, qual meio estamos utilizando etc. Entretanto, espero que, após esta

\footnotetext{
${ }^{39}$ No apêndice desta dissertação, esboço brevemente uma visão alternativa do Critério de Popper. Acredito, sim, que o Critério é útil para a análise lógica de teorias, mas não como maneira de "definir" a Ciência.

40 Trato da relação entre Ciência e Filosofia com maior aprofundamento numa seção posterior.
} 
seção, o leitor possa concordar comigo que ensinar um consenso rígido como sendo o retrato da Ciência será sempre um equívoco.

\section{4 - Leis, Hipóteses e Teorias}

Poucos conceitos científicos são tão mal compreendidos, divulgados e ensinados como os conceitos de lei, hipótese e teoria ${ }^{41}$. Tanto em minha pesquisa quanto em experiência como professor, pude verificar que divulgadores e leigos dizem de tudo acerca desses conceitos; estabelecem supostos limites entre eles; validam ou invalidam algo apenas por ser (ou por não ser) uma "teoria"; mas poucos saberiam (se é que algum saberia) traçar a linha divisória entre eles ("aqui acaba a hipótese e aqui começa a teoria"), distinguindo-os claramente entre si, assim como poucos saberiam dizer com claridade o que significa ser "verdadeiro" ou "falso" em cada caso.

Por exemplo, é do senso comum considerar algo falso ou, no mínimo, com bem pouca validade, devido a esse algo ser apenas uma "teoria". Inversamente, já pude verificar entusiastas da Ciência, e até professores e divulgadores, afirmando que, na Ciência, o conceito de teoria é justamente o contrário do senso comum: significa uma ideia que foi comprovada "verdadeira"! Novamente, observa-se o mesmo padrão de subestimar ou superestimar a Ciência. Há ainda outras ideias, cujas distorções, ao meu ver, são ainda mais graves. Por exemplo, há a ideia de que uma hipótese é uma suposição, e que se for "comprovada cientificamente" se transforma em uma teoria ${ }^{42}$ Como quase todos os problemas que estão sendo levantados nesta dissertação, esses derivam da quase total ausência de conhecimento da História e da Filosofia da Ciência ${ }^{43}$. É verdade que um cientista em atividade conhece esses conceitos, assim como "o que é Ciência" (como abordei anteriormente), pelo uso que faz deles e pelo

${ }^{41}$ Encontramos em Teixeira et al. (2009) uma análise da falta de compreensão desses e de outros conceitos metateóricos. Os conceitos igualmente mal compreendidos de "fato", "observação" e "experimentação" serão abordados na próxima seção.

${ }^{42}$ Ver, no Capítulo III, um caso concreto.

${ }^{43}$ Deixo claro que não acredito que exista "uma" História e "uma" Filosofia da Ciência. O que existem são "Histórias" e "Filosofias", de forma que um bom conhecedor desses campos deve, necessariamente, conhecer as diferentes abordagens de cada um, desenvolvidas ao longo da jornada do pensamento humano. 
treinamento formativo que recebeu em sua graduação. Ainda assim, dificilmente eles poderiam definir tais conceitos com satisfatória precisão, tratando de um conhecimento mais tácito do que teórico. $\mathrm{O}$ interesse maior em definir tais conceitos, certamente, é do filósofo. Mas o divulgador e o educador necessitam deles tanto quanto (Köhnlein \& Peduzzi, 2005), uma vez que são eles os anfitriões para o ingresso dos leigos no mundo científico. E é justamente pelo déficit no que diz respeito ao ensino da Natureza da Ciência que podemos encontrar, na raiz das visões distorcidas de Ciência, um mau entendimento acerca do que são leis, hipóteses e teorias.

Uma definição possível para hipótese é a de que ela é uma proposição (ou um conjunto de proposições) mais ou menos universais acerca do mundo e nunca assumida como certeza, mas como possibilidade. As hipóteses científicas, em sua maioria, possuem também um potencial de predição ${ }^{44}$. Sob esse ponto de vista, não há diferença fundamental entre uma hipótese e uma lei, no sentido científico. Normalmente, considera-se como sendo lei científica uma afirmação de um "fato", uma "regularidade" da natureza. Mas esse fato ou regularidade (caracterizada por repetições de efeitos similares na presença de condições iniciais similares) é descrito por meio de uma proposição universal, podendo ou não fazer uso de uma relação matemática (como o faz a Segunda Lei de Newton em sua forma mais conhecida: $F$ = m.a). O intrínseco caráter hipotético de uma lei é exibido pelo fato de que, no "mundo real", não nos deparamos com "fatos universais", mas tão só com casos particulares. Dessa forma, toda hipótese (e toda lei, uma vez que são essencialmente a mesma coisa) transcende a experiência, e nunca poderá ser, definitivamente, "provada verdadeira" por via experimental e observacional (por via empírica, em resumo). Nisso, em síntese, constitui a crítica de Popper ao verificacionismo positivista, tal como argumentado n'A Lógica.

Já uma teoria costuma diferir de uma hipótese apenas em tamanho, pois geralmente reúne em si um grande conjunto de hipóteses e leis, assim como as deduções delas derivadas. Toda teoria possui, portanto, em essência, as mesmas qualidades básicas da hipótese (e, por conseguinte, das leis): uma afirmação universal de uma possibilidade. Vejamos um exemplo. A gravidade newtoniana é uma lei, uma hipótese ou uma teoria? A resposta é: todas as três coisas! Se considerarmos todos os axiomas, postulados e deduções que estão nela contidos, teremos, grosso modo,

${ }^{44}$ Falarei especificamente sobre as predições em uma seção posterior. 
uma teoria. Mas, devido à sua natureza universal e potencial de predição, ela possui o intrínseco caráter hipotético acima citado, sendo, portanto, uma hipótese. E dentre as deduções que foram realizadas, temos a famosa fórmula $F=-G . M \cdot m / r^{2}$, que normalmente é chamada de "Lei da Gravitação Universal de Newton", mas que é apenas uma das deduções integrantes de um corpo teórico maior que a envolve e the dá fundamento. Seguindo o caminho inverso, ao dizermos que "uma força de interação entre dois corpos decai com o quadrado da distância que os separam", estamos relatando uma "lei natural", uma regularidade, que é, como já dito, uma hipótese. Essa hipótese pode ser incorporada, junto com outras tantas hipóteses, axiomas e postulados ${ }^{45}$, a diversas teorias (como de fato o foi, na Teoria da Gravidade de Newton, na Eletrostática Clássica, dentre outras teorias fundamentais da Física).

Um dos aspectos mais difíceis de se compreender com relação às hipóteses (incluindo-se aqui as leis e teorias) é o fato de elas não serem propriamente descrições de experiências e observações, sendo em realidade anteriores a elas, inclusive as condicionando. Essa afirmação constitui quase um paradigma da Filosofia da Ciência atual, sendo um ponto de concordância não só entre Popper e Kuhn, mas também presente em Hanson, Feyerabend, Chalmers, Laudan e outros (Silveira \& Ostermann, 2002). Teorias são explicações inventadas para tentar descrever o que observamos. Mas o que podemos observar é muito pouco: são como peças isoladas de um quebracabeças, sendo que não sabemos quais as dimensões do mesmo, e nem sequer temos conhecimento de qual seria a imagem que ele representaria se estivesse completo. Estamos como os povos antigos que observaram os pontos brilhantes no céu, as estrelas, e imaginaram figuras que se formavam com linhas imaginárias, inventadas, para Ihes dar significado. Da mesma forma, uma teoria é uma invenção para conectar os pontos, os dados empíricos dos quais dispomos, para formar uma imagem que nos seja reconhecível - uma explicação racional para o mundo, ao mesmo tempo em que nos habilita a predizer a posição dos pontos dos quais não dispomos no momento (exatamente como Mendeleiev previu a existência dos elementos Germânio, Gálio e Escândio, e Einstein previu a existência das ondas gravitacionais $)^{46}$.

\footnotetext{
${ }^{45}$ Axiomas e postulados são sinônimos que dizem respeito a proposições iniciais que não necessitam de demonstração, servindo de ponto de partida para demonstrações posteriores. Exemplo: os famosos postulados geométricos de Euclides.

${ }^{46}$ Tratarei especificamente sobre esses casos na próxima seção.
} 
Mas para o mesmo conjunto de pontos, ou de peças de quebra-cabeças, é possível inventar inúmeras imagens que os completem (tal como os diferentes povos imaginaram diferentes desenhos para as suas constelações, ainda que dispondo exatamente dos mesmos pontos). Os antigos empiristas, cujo expoente máximo é Francis Bacon, acreditavam que havia apenas uma explicação possível para o mundo e que, dispondo do mesmo conjunto de dados empíricos/observacionais, qualquer cientista com a visão suficientemente "purificada" chegaria às mesmas conclusões: o sábio desvelaria a lei natural que rege os fenômenos descritos pelos próprios dados. ${ }^{47}$

Os filósofos da Ciência posteriores trataram de demonstrar que isso era um equívoco, ao menos no que diz respeito a como a nossa Ciência funciona na prática: a primazia pertence à hipótese e a afirmação de Bacon se mostra irreal até mesmo para o seu próprio tempo. Consideremos Galileu, um dos mais ilustres contemporâneos de Bacon, sobre o qual Hanson (1958) faz uma análise detalhada dos métodos de investigação por ele utilizados, demonstrando como a invenção de hipóteses prévias aos experimentos foram decisivos para condicionar suas conclusões. Até mesmo Comte chegou a perceber, sem no entanto afirmar, tal primazia quando diz (Curso de Filosofia Positiva, 1978, p. 4):

"Todos os bons espíritos repetem, desde Bacon, que somente são reais os conhecimentos que repousam sobre fatos observados. Essa máxima fundamental é evidentemente incontestável, se for aplicada, como convém, ao estado viril de nossa inteligência. Mas, reportando-se à formação de nossos conhecimentos, não é menos certo que o espírito humano, em seu estado primitivo, não podia nem devia pensar assim. Pois, se de um lado toda teoria positiva deve necessariamente fundar-se sobre observações, é igualmente perceptível, de outro, que, para entregar-se à observação, nosso espírito precisa duma teoria qualquer. Se, contemplando os fenômenos, não nos vinculássemos de imediato a algum princípio, não apenas nos seria impossível combinar essas observações isoladas e, por conseguinte, tirar daí

\footnotetext{
47 Embora, eventualmente, essa visão baconiana seja tratada como ingênua e radicalmente empirista, não assumo que assim o seja. Por exemplo, "Bacon reconhecia que é preciso um trabalho teórico de ordenação para se criar as teorias" (Henrique, 2011, p. 34), o que contrasta com a ideia de que "os fatos falam por si só". Creio apenas que a visão de Bacon é a da Ciência ideal; não o que ela é de fato, mas o que ela deveria ser (e, portanto, a meta que deveríamos estar nos esforçando por alcançar). Sob essa perspectiva, os filósofos posteriores que o criticaram estariam, movidos por tal ou qual motivo, apenas buscando uma maior aproximação com a tal Ciência "real".
} 
algum fruto, mas seríamos inteiramente incapazes de retê-los; no mais das vezes, os fatos passariam despercebidos aos nossos olhos."

Apesar do nítido empirismo indicado na primeira frase, Comte não deixa de reconhecer, logo em seguida, a influência absoluta da hipótese sobre as observações. Apesar de ele acreditar em uma Ciência fundamentada sobre "fatos observados", a realidade acena para a direção oposta: são os "fatos observados" que se fundamentam em nossa Ciência — leis, teorias e hipóteses.

Esse aspecto da observação notado por Comte já é completamente defendido por Popper e é, em geral, um consenso ${ }^{48}$ entre os filósofos da Ciência dos séculos XX e XXI. Surpreendi-me, porém, ao me deparar com essa mesma ideia já em Hegel, quando diz em sua Preleções sobre a História da Filosofia (Os Pré-Socráticos, col. Os Pensadores, 1996, p. 120, [ ] meus):

"Se os escutamos [aos cientistas], descobrimos que apenas observam, dizem apenas o que veem: mas isto não é verdadeiro; inconscientemente transformam imediatamente o que viram, através do conceito. $E$ o conflito não resulta da oposição entre observação e conceito absoluto [universal, como todos os nossos conceitos científicos], mas da oposição do conceito limitado e fixo [a tradução conceitual que fazemos de um fato empírico] contra o conceito absoluto [universal]."

Ou seja: os cientistas não confrontam "fatos" com "teorias" (algo que repetidamente é afirmado por divulgadores de Ciência), mas confrontam seus próprios conceitos imputados aos fenômenos com os conceitos que previamente havia assumido como pressupostos.

Após interessantes comentários sobre experimentos científicos de sua época (como os de Lavoisier sobre os elementos químicos), criticando as interpretações que os cientistas davam às suas constatações empíricas, Hegel completa dizendo que ( $p$. 121, [ ] meus):

"Esta é a experiência: mas eles [os cientistas] corrompem toda percepção das transformações por causa do conceito fixo; pois já trazem consigo, quando vão realizar a experiência, os conceitos fixos do todo e das

\footnotetext{
${ }^{48}$ Ainda que seja um caso raro, considero esse consenso como uma evidência do poder da Filosofia em esclarecer ideias poderosas, assim como evidência de que o pensamento puro (a Filosofia fundamental) pode progredir tanto quanto o pensamento auxiliado pela evidência empírica (a Ciência, em outras palavras).
} 
partes, da constituição de partes, do já-ter-estado-presente daquilo como tal, que se mostra surgindo."

Fascinantes trechos de Hegel. Não há observação que esteja livre de conceitos preconcebidos para ser interpretada. Sem tais conceitos, os fatos sequer seriam percebidos. Se, pela observação, dizemos que "a grama é verde", é porque temos conosco uma teoria, ainda que rudimentar, do que é uma grama e do que é uma cor, para só então podermos afirmar que a "grama" possui a "cor verde". Mas, novamente, essas teorias rudimentares necessariamente transcendem a experiência, pois "grama" e "verde" são conceitos universais, enquanto aquilo que temos à nossa frente é uma "grama verde" particular. A respeito disso, diz Popper (2013, p. 483):

"Quase todos os enunciados que emitimos transcendem a experiência. Não há linha divisória nítida entre uma 'linguagem empírica' e uma 'linguagem teorética': a todo instante estamos teorizando, mesmo quando emitimos os mais triviais dos enunciados."

Vale aqui um comparativo. Quando Popper se refere aos "mais triviais dos enunciados", ele tinha em mente exemplos como o da "grama verde" (ele utiliza como exemplo um enunciado tão trivial quanto: "há água dentro do copo"). É claro que ninguém pensa que "está teorizando" quando faz uma afirmação desse tipo, uma vez que tais trivialidades são tomadas como absolutamente óbvias. Mas, na linguagem comum, as pessoas costumam utilizar o termo "teorizar" quando, por exemplo, imaginam explicações para perguntas não respondidas em séries e filmes. Dispondo dos mesmos dados empíricos (as informações confirmadas pela própria narrativa), eles buscam completar as lacunas, inventando explicações que sejam racionais e harmoniosas com o que já está estabelecido na obra. Os espectadores acabam por chegar em explicações muito variadas e, no final das contas, contentam-se cada um com a sua preferida. Afinal, "não passam de teorias".

Alguém tomado pelo cientificismo, ao contrário, tende a crer que teorias científicas são, por si só, "mais válidas" do que essas teorias da vida comum — outra forma de dizer que a Ciência é a "forma de conhecimento superior" (Henrique, 2011; Haack, 2012). Mas em realidade, isso não pode ser assim de forma alguma! Podemos, talvez, dizer que sejam "mais empíricas", ou até mesmo "mais importantes", ou ainda "mais concretas", mas, sendo uma teoria de tipo qualquer, um enunciado jamais poderá ser "validado". Isso é algo que, apesar de já ter sido esclarecido por Popper 
n'A Lógica, permanece desconhecido por parte de nossos cientistas, professores e divulgadores. Em suas palavras (2013, p. 483):

"Não podemos demonstrar diretamente, nem mesmo quanto a um objeto físico, que, na ausência de forças, ele se desloca ao longo de uma linha reta; ou que atrai e é atraído por outro corpo físico, de acordo com a lei do inverso do quadrado. Todas essas teorias aludem ao que poderíamos chamar propriedades estruturais do mundo e todas elas transcendem qualquer experiência possível."

Dentro do contexto de uma série ou filme, o que já foi narrativamente mostrado é tratado como axioma, e é, portanto, uma "verdade" garantida, na qual as teorias dos fãs podem seguramente se basear. Já um cientista possui, para se basear, não "fatos" ou "verdades", mas as teorias anteriores das quais tem disposição, assim como os axiomas fundamentais dos quais não pode prescindir. Mas não podemos considerar que existem "fatos" em sentido puro, separado de ideias preconcebidas. Diz Popper (2013, p. 486, [ ] meus):

"(...) necessitamos de [leis transcendentais universais e/ou teorias] porque não há 'experiência pura', mas tão somente experiência interpretada à luz da expectativa, ou teorias que são 'transcendentes' e porque um teorizador é um homem que deseja explicar a experiência e porque a explicação envolve o uso de hipóteses explicativas que, para serem testadas de modo independente, hão de transcender aquilo que se espera explicar."

Darwin não chegou à Teoria da Evolução partindo da simples observação e comparação de espécimes e de seus habitats. Pelo contrário, já possuindo uma ideia rudimentar de Evolução, herdada em parte de seu avô, assim como de Lamarck e de outros evolucionistas que anteciparam boa parte de suas ideias, ele "viu" a evolução gradual das espécies por toda parte em que olhava. Suas observações estavam condicionadas pela teoria que já havia aceitado. Esse condicionamento o levou a prestar maior atenção, uma atenção devidamente instruída para "enxergar" determinados detalhes em circunstâncias antes ignoradas. Ele teve, então, que reinterpretar esses fatos à luz de sua teoria, ajustando-a quando fosse necessária uma acomodação mais adequada. Salvo que não necessitam mais inventar uma Teoria da Evolução, é o que os biólogos evolucionistas continuam fazendo até hoje: cada novo fóssil descoberto, cada nova estrutura biológica estudada, cada nova espécie viva identificada é interpretada à luz da evolução, dando a impressão de 
encaixar-se perfeitamente a ela, sugerindo que a Evolução é um fato da natureza. Isso se aplica a absolutamente todas as teorias das quais temos disposição: cada reação química é interpretada à luz da teoria atômica, cada emissão radioativa é interpretada à luz da teoria quântica etc.

E é também por esse mesmo motivo que o adepto da chamada Teoria do Design Inteligente (considerada como pseudociência, tal como discutirei mais adiante) verá uma estrutura inteligentemente desenhada em cada ser vivo com o qual se deparar, pois é exatamente isso que sua visão está condicionada a ver. Com efeito, qualquer ideia que tenhamos acerca do mundo, pela natureza teórica (e portanto explicativa/preditiva) dessa ideia, tenderá a se confirmar diante de nós (o chamado "viés de confirmação"). Os fatos que não se encaixam nesse viés comumente serão ignorados ou sequer serão percebidos (como disse Kuhn e até mesmo Comte em passagens anteriormente citadas nesse trabalho). Embora o viés de confirmação seja em muitos casos considerado um vício de nossa percepção, é o modo padrão de ação do Cientista, e não apenas do leigo. Popper percebeu essa dificuldade e a expressa da seguinte maneira (2013, pp. 114-5):

"Como explicar que tão frequentemente alcançamos êxito com as teorias por nós elaboradas - como explicar que existem 'leis naturais'? (...) as observações e, com mais forte razão, os enunciados de observação e enunciados que registram resultados experimentais, são sempre interpretações dos fatos observados - são interpretações à luz de teorias. Aí está um dos principais motivos pelos quais sempre se torna ilusoriamente fácil encontrar verificações de uma teoria e que explica por que devemos adotar uma atitude altamente crítica, em relação a nossas teorias, se não quisermos raciocinar em círculo - porque, em suma devemos adotar a atitude de refutação frente às teorias."

Compartilho do ideal de uma criticidade em mais alto grau referente a nossas teorias (o leitor desse trabalho perceberá, ao longo das páginas, muitas críticas a teorias hoje consideradas "inquestionáveis"), mas é preciso rendermo-nos ao fato de que a maioria dos cientistas não age assim; o padrão não é de ataque implacável contra as teorias, mas de sua obstinada defesa.

Existe também a ideia de que toda nova teoria deve ser harmoniosa com as suas antecessoras, sendo apenas uma generalização ou aumento de precisão delas. Niels Bohr formulou essa ideia, batizando-a de Princípio da Correspondência. Isso 
gera a visão acumulativa de Ciência, na qual ela cresce organicamente, a pequenos passos, que apenas adicionam mais conceitos e dados empíricos; conceitos e dados esses que nunca diferem radicalmente daqueles que já são aceitos. Demonstra Kuhn que tal ideia não se sustenta, e para tal demonstração desenvolveu o conceito de incomensurabilidade, o qual será abordado com maiores detalhes no Capítulo II.

Para resumir, uma teoria científica não é, de maneira alguma, uma "verdade" ou "algo comprovado" como pretendem os cientificistas. Mas tampouco é uma "mentira" ou "algo sem fundamento na realidade", como proclamam alguns leigos e os adeptos dos movimentos anticiência. E nesse último caso, é interessante notar que, para afirmar que algo "é só uma teoria" e portanto "não é verdade" ou "não condiz com a realidade", a pessoa está fazendo uso inconsciente de uma teoria! Ela precisa, para fazer tal afirmação, de uma teoria sobre "o que é uma teoria", e também sobre "o que é ser alguma coisa", para só então poder afirmar que algo "é só uma teoria".

Afirma Kuhn (2012, p. 61) que "teorias obsoletas não são em princípio acientíficas simplesmente porque foram descartadas". Completo dizendo que uma teoria é uma teoria por sua própria natureza, antes e independentemente de qualquer comprovação empírica (tal como o é, nesse exato momento, a Teoria das Cordas e as diversas teorias do surgimento da vida). A Teoria Evolucionista de Lamarck, o Teoria do Flogisto, do Calórico, do Fluido Elétrico, da Força Vital etc. foram, são e para sempre serão teorias - podem, sim, ser classificadas, ao bel prazer do classificador, como "antigas", "ultrapassadas", "sem sentido", "metafísicas", "pseudocientíficas" e inúmeros termos depreciativos mais; porém, ainda assim, jamais serão outra coisa que não teorias. E pur si muove!

Novamente, em termos extremamente simples, uma teoria é uma explicação inventada para um determinado conjunto de fenômenos. Para qualquer conjunto de fenômenos, inúmeras teorias (explicações) são possíveis. Kuhn analisa essa questão da multiplicidade de teorias possíveis com as seguintes palavras (2012, p. 63):

"Tendo sido instruído para examinar fenômenos elétricos ou químicos, o homem que desconhece essas áreas, mas sabe como proceder cientificamente, pode atingir de modo legítimo qualquer uma dentre muitas conclusões incompatíveis. Entre essas possibilidades legítimas, as conclusões particulares a que ele chegar serão provavelmente determinadas por sua experiência prévia em outras áreas, por acidentes de sua investigação e por sua própria formação individual." 
Mais adiante, na p. 158, afirma, de forma resumida:

"Os estudiosos da filosofia da ciência demonstraram repetidamente que mais de uma construção teórica pode ser aplicada a um conjunto de dados determinado, qualquer que seja o caso considerado."

O que leva à escolha entre teorias é um outro assunto, bastante complexo, e que será analisado em outra parte. O fato é que, independentemente da teoria escolhida, ela jamais poderá ser empiricamente "comprovada"49; e se adotarmos rigorosamente o Critério de Popper, ela de fato já está provada falsa por aquela parcela de fenômenos que pretende, sem sucesso, explicar. Ensinar os conceitos de hipóteses, leis e teorias sem levar em conta esses aspectos sutis, resultará, inevitavelmente, em distorção.

\section{5 - Predição, Observação, Experimentação e Descobertas}

Tendo esclarecido a natureza fundamental das leis, hipóteses e teorias, chegou o momento de analisar, em pormenor, a questão da predição e sua relação com as observações e experimentos científicos.

Ao aprofundar o estudo em História da Ciência, fica subentendida a existência, ao menos, de dois tipos possíveis de previsões derivadas de teorias. O conhecimento dos tipos de previsão é fundamental para o entendimento do grau de corroboração de uma teoria. Diz Popper (ver Popper, 2013, capítulo X) que o realmente importante não é o número de testes ou corroborações que uma teoria apresenta, mas o rigor e a qualidade de tais testes e corroborações. E a maneira, por excelência, de se corroborar uma teoria que se diga "científica" é através de suas previsões. Vejamos agora quais são as duas espécies de previsões que, em geral, encontramos na história da Ciência.

Existem, em primeiro lugar, as previsões de "existência de entidades" e de

\footnotetext{
${ }^{49}$ Novamente, só podemos obter, da experiência e da observação, informações de casos particulares. Essas informações, por mais numerosas que sejam, não podem nunca justificar logicamente um enunciado universal, tal como o são as teorias. Esse é o Problema da Indução em si mesmo.
} 
como essas entidades devam ser. Popper chamou esses enunciados de "enunciados há" (2013, capítulo III, seção 15). Como exemplo, temos os dois exemplos já citados na seção anterior: a previsão da Teoria da Periodicidade dos Elementos, que poderia ser expressa como \{"devem existir os elementos X e Y com as propriedades K e L"\} e a previsão da Teoria Geral da Relatividade, que tomo a liberdade de expressar como \{"deve existir o fenômeno de ondas gravitacionais, que se propagam com a velocidade da luz e possuem a intensidade $Z$ para as condições iniciais W" $\}$. Como exemplos extras, podemos adicionar a previsão da Teoria da Evolução, de que quanto mais antigos forem os fósseis, mais difícil será a diferenciação e a classificação dos mesmos em espécies e em gêneros (pois a evolução tende a ocorrer na direção de especializar as espécies), além da previsão da existência da antimatéria, do Bóson de Higgs etc. Esse é o tipo mais comum de previsão. Na literatura mais moderna, esse tipo de previsão é chamado de "acomodação" — são simplesmente dados que se encaixam em uma hipótese concebida em um momento anterior.

O segundo tipo é a previsão de eventos futuros, com alta precisão não só de tempo e lugar, mas também em quaisquer outros parâmetros envolvidos. Aqui se enquadram as célebres previsões de Halley - para o retorno do cometa que leva o seu nome no ano de 1758 - e a de Einstein - para a possibilidade de vermos determinada estrela, normalmente coberta pelo Sol, durante o eclipse solar de 1919.

Ao primeiro tipo, a "acomodação", darei o nome de previsão retroativa; enquanto que ao segundo, de previsão verdadeira. Para um "previsionista" (predictionist), tal como era o próprio Popper, esse último tipo, como o nome já indica, é de tipo superior. O debate para definir o que significa "ser superior" nesse caso, assim como se tal superioridade realmente existe, ocorre, ao menos, desde o século XIX. William Whewell (1794-1866), grande polímata conhecido por ter cunhado o termo "cientista", sustentava que as previsões verdadeiras davam grande peso às teorias, pois acertar um evento futuro com base num conhecimento presente não poderia se dar ao acaso (Whewell, 1968). Por outro lado, J. S. Mill (A System of Logic, 1843, vol. 2), que debateu diretamente com Whewell, e J. M. Keynes (em seu clássico A Treatise on Probability, de 1921) defenderam que tal impressão (a de que uma teoria tivesse mais valor ou peso caso suas previsões fossem confirmadas) era uma ilusão. Keynes chega mesmo a dizer que tais confirmações eram casos de "sorte". A base de tais críticas é, como já era de se esperar, o Problema da Indução: uma previsão 
"acertada" (que é sempre um caso particular) nunca pode verificar completamente nenhuma hipótese (que é sempre universal). Mesmo sabendo disso, Popper defendeu o "previsionismo50"; mas, como já vimos, não através da crença de que uma teoria é "verificada" por uma previsão acertada, e sim, que apenas sobreviveu a um teste contra falseabilidade. Mais do que isso, para ele, a própria capacidade de prever algo (e, portanto, de ser falseada) é o que eleva a categoria de uma teoria qualquer em "teoria científica". Nesse caso, Popper troca a palavra "verificada" por "corroborada", que possui uma nuance de significado um tanto diferente. Com relação a previsões, e para fins do presente trabalho, escolho estar ao lado de Popper, conforme argumentação feita a seguir.

As previsões retroativas fazem referência a entidades que já devem existir, estando, portanto, presentes desde antes da formulação da teoria. É, nesse sentido, uma referência ao passado (o exemplo da previsão de fósseis torna explícita essa característica temporal, embora isso também se aplique a todas as outras previsões desse tipo). A confirmação de uma previsão retroativa corrobora a teoria, porém em baixo grau. Isso ocorre por uma série de motivos que irei agora discutir. Um desses motivos é o fato de que "enunciados há" não são falseáveis (algo já comentado em uma seção anterior). Não se pode nunca demonstrar que "algo não existe", pois não é possível garantir que procuramos de fato em todos os lugares. Além disso, certos lugares são, de fato, completamente inacessíveis. (É por esse motivo que, possivelmente, jamais tenhamos um muito alto grau de certeza [corroboração] da constituição do núcleo de outros planetas, ou mesmo da própria Terra.) Isso quer dizer, em outras palavras, que o fato de essas entidades não serem encontradas, mesmo em buscas rigorosas e extensas, não será motivo para afirmar que a teoria que as predisse está falseada. Afinal, pode-se sempre argumentar que ainda venhamos a encontrar tal entidade no futuro.

Para esse caso, o exemplo das ondas gravitacionais é um dos mais dramáticos da história. $O$ intervalo entre a sua predição e a sua detecção foi nada menos do que

50 Existem vários tipos de previsionismo; por exemplo, o previsionismo "forte" defende que uma teoria capaz de fazer previsões verdadeiras é definitivamente mais forte de que outra que apenas pode fazer acomodações, enquanto o previsionismo "fraco" diz apenas que essa diferença favorece epistemologicamente a teoria que faz a previsão como sendo um fator a mais, e não necessariamente o mais importante ou decisivo na escolha entre elas. Aqui, adotarei uma posição intermédia, tendendo mais para o previsionismo "fraco". O previsionismo está intimamente relacionado ao realismo científico, o qual abordarei mais adiante. 
um século! Não conheço, e creio que realmente não houve, nenhum cientista que tenha abandonado a teoria da Gravitação Universal devido à previsão das ondas gravitacionais não ter sido confirmada. Isso, pois, consideraram que o fato de elas não terem sido detectadas não era motivo para tanto. Nenhum acusou a teoria de ter feito uma falsa previsão, mas direcionaram suas críticas às nossas próprias limitações e dificuldades em detectá-las. Mas aí cabe a pergunta: e se, de fato, tais ondas não existissem? Provavelmente continuaríamos a busca indefinidamente, por décadas e décadas (séculos e séculos?), sem nunca termos a certeza de que elas de fato não existem, mas com uma persistente esperança de que, sim, existem. A busca apenas seria interrompida quando uma teoria nova surgisse; uma que afirmasse enfaticamente que tais ondas não existem e que, portanto, deveríamos abandonar a busca por elas. Foi exatamente o que aconteceu com as tentativas de se detectar o éter: as buscas teriam continuado indefinidamente, não fosse Einstein e sua demonstração de que a ideia de éter era supérflua para os fins de interesse à época.

O exemplo da previsão de Mendeleiev acerca dos elementos faltantes em sua tabela também merece uma análise. Um dos elementos previstos pela sua classificação seria similar ao manganês. Esse elemento "precisava" existir, pois era um "buraco" bem no meio da tabela periódica clamando para ser preenchido. O tal elemento só foi "descoberto" em 1937, mais de meio século após a previsão de sua existência: tratava-se do tecnécio, ocupando a posição 43 em ordem de número atômico. Acontece que tal elemento de fato não existe na natureza: ele não foi realmente "descoberto", mas sintetizado por Carlo Perrier e Emilio Segré. Não é demais lembrar que Mendeleiev desconhecia por completo a nucleossíntese, uma vez que o primeiro núcleo foi sintetizado apenas em 1919, 12 anos após a sua morte, quando Rutherford produziu oxigênio a partir de nitrogênio bombardeado por partículas alfa. O tecnécio produzido em 1937, o primeiro elemento artificial (daí seu nome, "technetos"/artificial), é resultado da fusão nuclear, seguida de decaimento beta, de molibdênio com deutério.

Imaginemos por um instante que a nucleossíntese fosse um fenômeno impossível. Isso significaria que nunca poderíamos produzir tecnécio de forma alguma, resultando que tal elemento jamais seria detectado. A tabela periódica teria uma lacuna permanente e, muito provavelmente, os químicos persistiriam em sua busca pelo elemento faltante. Afinal, aquela lacuna dava todos os indícios de que 
deveria existir um elemento naquela posição. Mas é importante que fique claro que o fracasso em encontrar o dito elemento não anularia de forma alguma a Teoria da Periodicidade.

Trazendo a análise para o caso dos fósseis previstos pela teoria evolutiva, a situação seria mais notória. Sabemos, hoje, o quão difícil é a fossilização de um ser vivo. Estima-se que menos de $1 \%$ de tudo o que já viveu no planeta Terra tenha sido fossilizado. Portanto, na ausência de fósseis que corroborem as previsões retroativas da Evolução, seria muito simples argumentar que eles se perderam ao longo das Eras, não sendo motivo para considerá-la falsa. Esse argumento, aliás, é muito usado por Darwin n'A Origem das Espécies - algo que vejo como negativo, pois trata a ausência de evidência como algo de menor peso e que não deveria ameaçar gravemente a teoria. Se, por um lado, ausência de evidência não é evidência de ausência, ao menos deveria ser considerado um ponto contra uma teoria, mas nunca a favor, e nem sequer como neutro. Como alguns de tais fósseis foram de fato encontrados, consideramos que a teoria aumentou o seu grau de corroboração, porém em baixo nível. É preciso notar aqui que as previsões retroativas oferecem um menor grau de corroboração, caso se confirmem, justamente pelo fato de que, em caso de negação, também não possuem um grande poder de falsear a teoria. Dito de outra maneira, se uma previsão tem pouco poder de falsear uma teoria, igualmente terá pouco poder de corroborá-la; é uma espada de dois gumes.

Uma das atividades padrão de um cientista é testar previsões retroativas afim de aumentar o grau de corroboração de teorias. Devido ao baixo peso que tem essa corroboração, quando ela ocorre não há uma grande surpresa ou novidade envolvida: era exatamente o que era esperado da teoria que está sendo atualmente adotada como programa de pesquisa. Foi com relação a isso que Kuhn afirmou que (2012, p. 135) "... o sucesso de uma investigação [como descobrir um novo elemento da tabela periódica] era [é] motivo para congratulações, mas não para surpresas". Não que tais congratulações sejam desprezíveis; ao contrário, notáveis teses e muitos dos prêmios Nobel foram oferecidos a cientistas que realizaram descobertas desse tipo. O ponto levantado é que tais descobertas não produzem novidades na Ciência. E aqui somos levados à análise do outro tipo de previsão: a previsão verdadeira.

É claro que a palavra "verdadeira" invoca, por si, uma conotação de superioridade. Mas o ponto principal vem do significado gramatical de "previsão": 
"antevisão, presciência, análise, estudo ou cálculo feito com antecedência (de algo que deverá ocorrer no futuro)"51. O poder maior da Ciência, que dá ao ser humano a sensação (muitas vezes superestimada, é verdade) de controle sobre a natureza, vem de sua capacidade de prever eventos futuros. Prever o futuro é algo que podemos encontrar em toda mitologia e religião, na forma de profecias e oráculos, assim como é, conforme a história da Ciência parece demonstrar, o principal motivo da Astronomia ter sido a primeira ciência solidamente estabelecida. Embora não seja próprio da Ciência prever "como será o seu dia" ou quando (e se) você "vai encontrar o amor da sua vida", suas previsões sobre fenômenos naturais são do mais estimado valor. A nossa sobrevivência sempre dependeu de tais previsões. Os primeiros astrônomos debruçaram-se por desenvolver a capacidade de prever as estações do ano e a produzir calendários tão precisos quanto possível. Milênios depois, Halley e Einstein continuaram essa tradição milenar, fazendo previsões precisas envolvendo o futuro de corpos celestes.

Fazer uma previsão de um evento futuro é muito mais arriscado, seja para o cartomante, seja para o cientista. Vidas, reputações ou muitos bilhões de dólares podem estar envolvidos. Para um previsionista, acertar com precisão uma previsão de evento futuro é a mais potente corroboração que uma teoria científica pode receber (assim como seria a melhor prova dos supostos poderes paranormais dos videntes que vão até os veículos de mídia para relatar como "será o ano que se inicia" ou "se o Brasil vencerá a Copa"). Mas, sendo as previsões verdadeiras como espadas de dois gumes, uma falha nesse tipo de previsão é um indício fortíssimo de que a teoria em questão, ou os poderes do vidente, possuem uma falha grave. Esses são os melhores testes possíveis para uma teoria: a cada previsão verdadeira confirmada (ou, diria Popper, que tenha resistido ao falseamento), mais e mais corroborada podemos considerá-la, e isso em mais alto grau. Isso de forma alguma significa que a teoria foi "comprovada" e que ela é "correta" ou "verdadeira", mas certamente nos dá motivos de a considerarmos como digna, e digna em muitos aspectos: demonstra que a mente que elaborou a teoria teve algo mais do que "sorte" ao seu dispor (seguindo o argumento de Whewell, é difícil crer que um palpite completamente aleatório poderia gerar uma previsão tão precisa quanto o retorno de um cometa com dia e hora marcada); demonstra que essa teoria, ainda que venha a ser substituída no futuro por

51 http://www.aulete.com.br/previs\%C3\%A30; verbete consultado em 23/11/2019. 
outra melhor, teve o seu valor e foi útil ao seu tempo; e também demonstra que há algo nela que pode ser usado favoravelmente em um argumentação contra uma teoria rival que seja incapaz de fornecer uma previsão como essa. Se em tudo o mais duas teorias forem equivalentes, então a que puder fazer previsões e resistir aos testes a ela impostos deveria ter a preferência. Em resumo, como citei em uma nota anterior, isso se aproxima da visão de previsionismo "fraco". (Tratarei mais sobre a escolha entre teorias no Capítulo II.)

Nem todas as teorias são capazes de fazer previsões verdadeiras. Há muitas teorias que são elas mesmas retroativas, fazendo mais referência ao passado (frequentemente ao passado longínquo, na casa dos milhões ou bilhões de anos) do que ao futuro. Incluem-se aqui a Teoria da Evolução, a Teoria do Big Bang e a, genericamente falando, Teoria Geológica (no que diz respeito à formação do planeta Terra, deriva de continentes etc.). Embora sejam muito poderosas para reconstruir 0 passado da Vida, da Terra e do Universo, essas teorias têm pouca capacidade de antever eventos futuros empiricamente verificáveis. A Teoria da Evolução não pode prever aquilo no qual determinada espécie virá a se tornar (embora possa haver certos padrões e tendências que podemos considerar como mais prováveis do que outros); a Teoria do Big Bang não pode prever o futuro do Universo ${ }^{52}$ e a Teoria Geológica não pode prever o futuro do planeta Terra. É verdade que há estimativas, cálculos e conjecturas acerca de todos esses possíveis futuros, contudo o que mais devemos levar em conta não é a previsão em si, mas a nossa capacidade de pô-la à prova. Todas essas teorias, ainda que se arrisquem a prever algo com base no conhecimento do passado, e mesmo com a ajuda de teorias auxiliares (como a Teoria Genética auxiliando a Evolução e a Teoria da Relatividade Geral auxiliando o Big Bang), exigem milhares, milhões ou bilhões de anos para que suas previsões se concretizem, tornando a sua verificação empírica inviável. E esse é o principal motivo pelo qual essas teorias deveriam ser consideradas como possuidoras de um menor conteúdo empírico; consequentemente, essas teorias possuem um grau menor de corroboração do que teorias capazes de fazer previsões verdadeiras.

Um dos maiores e ainda não resolvidos problemas surgidos na Física do século XX foi a incompatibilidade entre a Teoria da Relatividade e a Teoria Quântica. Essa

52 É fato que há várias previsões já calculadas ou propostas, como a da "morte térmica" ou a do "Big Crunch", mas existe o incontornável problema que explico nas linhas seguintes do texto. 
incompatibilidade assume proporções cada vez mais aterradoras devido ao fato de que ambas as teorias possuem um grandíssimo conteúdo empírico. Ambas fazem previsões verdadeiras com os mais altos graus de precisão já alcançados por qualquer teoria proposta em nossa história, tendo acumulado corroborações mais e mais valiosas ano após ano. Como (e se) tal incompatibilidade será resolvida no futuro, teremos que aguardar pelas próximas décadas para saber. Os experimentos rigorosíssimos pelos quais tais teorias passaram não possuem qualquer paralelo na Evolução, no Big Bang e na Geologia. Esse, inclusive, é um grande desafio para os darwinistas, cosmólogos e geólogos deste século: elevar o conteúdo empírico de tais teorias, habilitando a possibilidade de experimentos corroborativos mais e mais rigorosos e permitindo previsões verdadeiras passíveis de teste. Uma única previsão verdadeira traz mais valor de corroboração para uma teoria do qualquer número de previsões retroativas. Se a Teoria da Evolução puder prever, em algum momento futuro, que "a espécie $X$, depois de $Y$ gerações e sob as condições ambientais $Z$ irá desenvolver a estrutura/capacidade W", e essa previsão se cumprir com rigorosa precisão, isso terá mais valor do que a soma de todas as corroborações já obtidas provenientes da anatomia comparada, da embriologia comparada, da análise genética e da análise e comparação de fósseis de todos os tipos, intermediários ou não; isso pois todas essas corroborações são, de fato, acomodações (na visão de um previsionista, vale relembrar).

Depois dessa discussão, acredito ter ficado claro o papel fundamental da experiência na Ciência: testar teorias; em particular, testar suas previsões preferencialmente as previsões verdadeiras, mas, na falta dessas, que sejam testadas as previsões retroativas. Existe ainda na literatura, no ensino e na divulgação uma visão empirista baconiana de que as teorias e as hipóteses emergem de experimentos (ou de observações, que, no fundo, são a mesma coisa). Comentei sobre isso no início desta seção. É aquela visão positivista de que o mesmo conjunto de dados empíricos, coletados via observação ou experimentação, fará qualquer cientista, com a visão suficientemente "purificada", chegar à exata mesma conclusão. Não nego que isso talvez fosse possível em um caso extremamente idealizado; a saber, se dispuséssemos de absolutamente todos os dados empíricos necessários para estabelecermos a teoria e se pudesse ser determinada com precisão o que seria (e como obter) essa visão "purificada" (uma visão apurada e completamente livre de 
ideias preconcebidas). Talvez não houvesse um único objetor da Teoria da Evolução se dispuséssemos de absolutamente todos os fósseis, de todas as gerações, de todos os seres que já viveram na Terra. Talvez todos os povos antigos tivessem chegado nas mesmas constelações caso as estrelas visíveis fossem tão numerosas e estivessem tão próximas que formassem linhas contínuas no céu (ainda assim, poderiam interpretar os desenhos de forma diferente - um sorriso para uns pode simplesmente ser uma banana ou um arco para outros). Infelizmente, um acesso ilimitado à informação empírica desse tipo, ou mesmo a existência dessa informação, é algo que não temos à disposição.

Persiste no imaginário popular (e também no imaginário de alguns especialistas...) aquela figura do cientista que observa tudo na natureza, ou que faz os mais diversos e espalhafatosos experimentos em seu laboratório, só para ver se "descobre alguma coisa". Esse é o absurdo que Mario Bunge chamou de "Credo do Físico Inocente" (Filosofia da Física, 1973). Silveira e Ortermann (2002), quase vinte anos atrás, já reforçavam um questionamento que ainda não foi respondido: como e por que tal visão tão ingênua continua tão inabalável na educação científica, mesmo tendo sido tantas e tantas vezes refutada na literatura? Posteriormente, trabalharei mais sobre essa pergunta. Sigo agora tentando fornecer mais um argumento, que visa se somar aos inúmeros outros já existentes, para tentar modificar essa visão.

Experimentos e observações são feitos para se testar hipóteses. Evidentemente, isso torna obrigatória a preexistência das hipóteses. Todo o aparato experimental será organizado para esse fim, com a clara intenção de excluir todas as variáveis irrelevantes para a investigação em questão. Não há tempo nem recursos materiais para que sejam feitos experimentos a esmo. Sem hipóteses, não há como determinar o que é importante, o que deve ser verificado e o que deve ser ignorado. Para se chegar à lei que leva o seu nome, Georg Ohm já tinha consigo a hipótese de que a tensão e a intensidade da corrente elétrica em um circuito poderiam estar relacionadas. Só partindo dessa hipótese, ele poderia ter elaborado os circuitos que o levaram a estabelecer que tal relação realmente existe e qual seria exatamente essa relação. O mesmo pode ser dito para Charles Coulomb e a sua famosa balança de torção. Ou para James Joule e seu experimento para estabelecer a equivalência mecânica do calor. Os exemplos seguem ad nauseam. Nas palavras de Popper (2013, p. 115), "a teoria domina o trabalho experimental, desde o seu planejamento inicial até 
os toques finais, no laboratório".

Poder-se-ia objetar, dizendo que um cientista só elabora uma hipótese após observar um fenômeno que não consegue explicar. Isso está de acordo com aquele antiquado modelo de "método científico", há décadas tão ensinado e divulgado aos leigos e jovens estudantes, onde a observação ocupa o primeiro lugar, a formulação de hipótese o segundo e o teste empírico o terceiro. Esse argumento é tentador e parece ser simplesmente uma descrição óbvia do fazer científico. No entanto, ele não se sustenta em uma análise mais profunda. Para começar, por que buscamos por respostas para certos fenômenos que observamos enquanto que para outros não? Estamos rodeados permanentemente de uma quantidade incalculável de fenômenos que não conseguimos explicar. Muitos deles ignoramos por completo. Da maioria, sequer nos damos conta de que não temos uma explicação. Não nos interessamos por esses problemas. Para bem poucos importa saber como o seu computador ou smartphone funciona; o que importa é que funciona. Um fenômeno apenas realmente nos chama atenção quando achamos que sabemos como ele funciona (ou como deveria funcionar). Ou seja: apenas quando ele contradiz alguma ideia prévia que tenhamos dele. Se não temos ideias prévias sobre um fenômeno, ele nos passa despercebido - não nos interessamos, não vemos como algo relevante a ser questionado e de ter nele o nosso tempo despendido.

O céu é azul. Alguém poderia aceitar a explicação de que ele é assim por possuir um pigmento azul, tal como as folhas são verdes por possuírem um pigmento verde. Essa é a nossa hipótese inicial, que explica, até certo ponto de modo satisfatório, a nossa dúvida. Se o céu permanecesse azul todo o tempo, tal como (quase) todo o tempo a folha permanece verde, provavelmente não teríamos muitos motivos para colocar em dúvida nossa hipótese inicial. Mas tão logo chega o pôr do sol, o céu fica amarelado, depois alaranjado, seguindo para um tom avermelhado, e então voltando a ser azul, mas agora em uma tonalidade mais escura, terminando em um preto profundo. Com o nascer do sol, vemos as mesmas mudanças de cores retornarem em ordem reversa: azul escuro, depois vermelho, laranja, amarelo e, por fim, o belo azul-celeste de todo dia livre de nuvens. Eventualmente, dia ou outro, surgem tons rosáceos ou violáceos em meio ao processo de transição "azul-amarelolaranja-vermelho-azul". Alguém que nunca se perguntou "por que o céu é azul" não teria formulado a primeira hipótese ("há um pigmento azul no céu"). Porém, para quem 
tivesse formulado tal hipótese, as mudanças diárias de cor constituem uma evidência fatal: não parece ser possível que a cor venha de um pigmento, mas parece estar relacionada com a presença e ausência do sol, assim como à sua posição ${ }^{53}$. E daí, com essa nova hipótese, esse alguém hipotético, claramente alguém dotado do espírito científico investigativo, prosseguirá observando e fazendo anotações a fim de testar sua nova hipótese. Mas notemos: a observação que o levou a formular uma hipótese apenas foi levada em conta porque ele já tinha uma hipótese prévia. Ele já tinha consigo um conceito, não só de que o céu é azul por tal ou qual motivo, mas tinha conceitos primordiais, axiomáticos (mesmo que ele não tivesse consciência disso), do que seria o "céu" e do que seria uma "cor", assim como possíveis motivos que levam uma coisa qualquer ter determinada cor.

Assim, cada observação de fenômeno que fazemos ao longo do dia poderá impactar ou não o nosso senso de dúvida ou de "segurança conceitual", dependendo, basicamente, de já possuirmos ou não uma hipótese para dar-lhe sentido, e apenas na medida em que tal hipótese parece contradita por aquilo que estamos empiricamente verificando. Não há, portanto, qualquer diferença entre observação (no sentido científico) e experimentação. Se uma pessoa observar o que quer que seja sem uma hipótese preconcebida, o resultado será que ela não verá nada de relevante, passando o fenômeno (ou melhor, a necessidade de explicá-lo) completamente despercebido do seu entendimento. Mas alguém que observa algo e vê ali uma pergunta a ser respondida, necessariamente já possui uma hipótese que, diante de sua percepção, acaba de ser golpeada.

Mas, de onde vem essa hipótese inicial? Será possível que a própria pessoa tenha formulado, ou ela a aprendeu ouvindo de alguém ou, talvez, lendo em algum lugar? Essa pergunta é instigante, e sua resposta não é tão simples como parece, mas não há espaço aqui para ir mais a fundo ${ }^{54}$. O ponto principal é que tal hipótese precisa existir para que uma observação científica tenha algum significado.

Isso mudaria fundamentalmente o modelo de "método científico" que nos ensinaram: em vez de "observação-hipótese-experimento", teríamos "hipóteseobservação/experimento". Em outras palavras, a primazia é da hipótese sobre a

\footnotetext{
${ }^{53}$ É possível que, se fosse um cientista atual, ele inventaria a hipótese ad hoc de que o pigmento celeste pode mudar suas características de acordo com a hora do dia...

${ }^{54}$ Uma excelente discussão a respeito pode ser encontrada em Conhecimento Humano de Bertrand Russell e também em $O$ Trivium de Miriam Joseph. Ver referências.
} 
experiência (ou, em termos mais filosóficos, do racionalismo sobre o empirismo), uma vez que é a hipótese que dita como o experimento deverá ser elaborado e como deverá ser interpretado. Experimento e observação são fundidos como sinônimos na prática científica: conclusões tiradas de observações servem para confrontar nossas hipóteses, de forma perfeitamente correspondente às conclusões que tiramos de um experimento qualquer. Em resumo: experimento e observação são equivalentes e sua função é testar previsões, sejam verdadeiras ou retroativas, testes esses que irão corroborar ou não a(s) hipótese(s) que deu (deram) origem a tais previsões.

Cabem agora algumas palavras acerca do significado de "descoberta" em Ciências. O termo vem recebendo variados tipos de críticas ao longo das últimas décadas e os filósofos da Ciência abordam-no de diversas formas. Genericamente falando, uma descoberta é uma observação de algo novo. Uma descoberta científica diz respeito à primeira observação de um ente (um novo ser vivo, um novo corpo celeste, um novo elemento químico) ou à primeira observação de um fenômeno. A história da Ciência nos permite identificar duas maneiras pelas quais uma descoberta pode ocorrer: podem ser descobertas previstas ou descobertas por acaso. Farei agora uma breve reflexão acerca desses dois tipos.

As descobertas previstas correspondem àquelas que são logicamente deduzidas de teorias já aceitas. Esse é o modo padrão da Ciência, tal como proposto por Popper (por ele chamado de método hipotético-dedutivo). O normal é que uma teoria inventada para explicar um fenômeno, quando articulada e levada aos seus limites de abrangência, derive de si uma série de consequências puramente lógicas e/ou matemáticas que dizem que este ou aquele ente ou fenômeno deve existir. Essas consequências correspondem, como o leitor já deve ter percebido, às predições retroativas: elas dizem respeito a entes ou fenômenos que necessariamente já devem existir, e que apenas não nos demos conta disso até o momento (seja por falta de capacidade técnica, seja por nunca termos dado atenção àquele aspecto particular da Natureza). Já foram dados muitos exemplos desse tipo. Vários elementos químicos, partículas subatômicas e fenômenos (ondas gravitacionais, buracos negros, aniquilação matéria-antimatéria, desvio da luz pela curvatura do espaço-tempo etc.) foram primeiro previstos por teorias, e só depois (algumas vezes, muito depois) foram detectados. Novas espécies vivas são mais difíceis de serem descobertas dessa maneira, pois não há como saber com alta precisão quantas espécies existem 
atualmente, muito menos a quantidade de espécies que viveram em passadas Eras geológicas. Podemos, porém, através da Teoria da Evolução, prever as características que devem estar presentes em fósseis antigos de linhagens específicas (por exemplo, prever como deverão se parecer os fósseis dos peixes ancestrais, ou dos dinossauros, ou das plantas etc.). Como já foi dito, esse é o tipo mais comum de descoberta (principalmente por ser o tipo mais comum de previsão).

Isso ocorre porque não temos condições (tempo, recursos, disposição) para procurar a esmo: precisamos de um mínimo de garantia, um mínimo de esperança, que encontraremos algo antes de empreendermos uma busca nos valendo de meios escassos. E não é demais lembrar que um fracasso em encontrar o ente previsto nunca pode ser utilizado como forma de refutação para uma teoria, uma vez que é impossível provar a inexistência do que quer que seja. Vale a máxima já citada: "Ausência de evidência não é evidência de ausência". É por isso, mais uma vez, que não há motivo para surpresas quando uma descoberta dessa ocorre: era exatamente o que esperávamos encontrar.

É justamente quando encontramos algo diferente do previsto que os problemas começam; nesse ponto, as teorias merecem passar, no mínimo, por uma revisão e, em casos mais graves, por uma substituição por uma teoria rival. Não consideramos, pura e simplesmente, a teoria antiga como refutada; tampouco abandonamo-la. Antes, é requisito que uma teoria rival já esteja disponível, pois abandonar a teoria, o paradigma atual, sem substituí-la por outra equivale a abandonar a própria Ciência (Kuhn, 2013). Tratarei mais a fundo sobre esse ponto no Capítulo II.

Por fim, temos as descobertas realizadas ao acaso. Várias delas podem ser vistas ao longo de toda a História da Ciência; mais do que normalmente é ensinado e mais do que alguns divulgadores, de tendência cientificista, gostariam de admitir. Entram aqui as famosas descobertas do oxigênio, da garrafa de Leiden, do planeta Urano, da penicilina, dos raios $X$, da radioatividade, da radiação cósmica de fundo, da fissão nuclear, entre outras ${ }^{55}$. A grande questão envolvida aqui é que análises mais profundas indicam que tais descobertas não foram tão devidas ao acaso como

\footnotetext{
55 Descobertas tradicionalmente atribuídas, respectivamente, a Priestley/Lavoisier, "eletricistas" holandeses, Herschel, Fleming, Roentgen, Becquerel/Curie, Penzias/Wilson, Meitner/Hahn. Vários desses casos foram estudados por Kuhn (2011 e 2013), problematizando tais eventos, argumentando que há "uma inadequação fundamental em nossa imagem de descoberta".
} 
algumas cronologias da história da Ciência costumam indicar. Normalmente, vemos o padrão: "O cientista $X$ estava estudando fenômeno $Y$ quando observou o fenômeno $Z$, este último inesperado e sem explicação. Em seguida, o cientista passou as próximas semanas estudando intensamente o fenômeno desconhecido até tirar alguma conclusão (normalmente, a conclusão de que realmente se trata de um fenômeno ainda não identificado, além de elaborar alguma explicação elementar inicial)". Essa descrição, anedótica e caricata, esconde as complexidades reais envolvidas em casos como esses. N'A Estrutura (2013, Capítulo 5), Kuhn analisa os casos da descoberta do oxigênio e dos raios $X$, mostrando alguns fatores que em geral são omitidos nos relatos comumente feitos. O caso da descoberta do oxigênio é um dos mais marcantes e é muito difícil definir quando e quem exatamente o "descobriu" (se Priestley ou Lavoisier).

O argumento principal é: as descobertas feitas "ao acaso" ocorrem apenas em situações propícias. Em todos os casos, os descobridores eram cientistas do mais alto calibre, muito bem versados nas teorias de que tinham disposição, além de excelentes observadores e experimentadores ${ }^{56}$. Em especial, a hipótese que orientava os observadores foi a responsável pela estranheza que sentiram ao se depararem com o inusitado. As mesmas observações devem ter sido feitas por outros experimentadores antes; mas sem uma hipótese que diga claramente: "há algo aqui que não deveria existir", certamente passaram despercebidas.

Fleming sabia (ou seja, aceitava a hipótese de) que fungos normalmente não inibem a ação de bactérias. Foi a anomalia nesse padrão previamente assumido que o levou a perceber que o seu saber estava, no mínimo, incompleto. A convicção que um cientista coloca nas hipóteses que o guiam é fundamental. Se ele não estivesse plenamente convicto, tomando como muito certo, de que "fungos não inibem bactérias", a verificação de um fenômeno oposto não teria causado o espanto necessário para merecer a sua atenção. Quantos experimentadores do início do século XIX deveriam ter bússolas próximas a circuitos elétricos? Quantos devem ter observado o fenômeno da deflexão da agulha da bússola com a passagem de corrente

${ }^{56}$ Em realidade, o processo de qualquer "descoberta" é muito mais complexo do que isso. Mais do que eventos pontuais, dados a cabo por uma única pessoa em um único lugar, tratase de uma construção coletiva que se dá ao longo de vários anos. Bagdonas, Zanetic e Gurgel (2017), num excelente artigo perscrutando a história da "descoberta" da expansão do Universo, concluem que "seria muito mais interessante apresentar a criação das teorias como um processo estendido por um período e que envolve vários colaboradores". 
elétrica nesse circuito? Por que foi Oersted, e não outro, a notar a importância desse fenômeno? O que chamou a sua atenção? O que ele tinha ou fazia de diferente quando comparado aos seus pares? Tudo indica que ele, simplesmente, estava devidamente preparado para ver o que viu. Estava pronto para identificar uma anomalia, que para tantos outros ou foi invisível ou foi insignificante, dando mais uma demonstração de que as mesmas observações empíricas não obrigatoriamente levam cientistas diferentes às mesmas conclusões. De fato, sequer se mostram como de igual interesse para todos eles e, principalmente, não fazem sentido sem que tenha sido previamente aceita uma teoria que Ihe atribua importância.

Com base em toda a pretérita argumentação, junto-me ao coro dos que defendem que o ensino do "método científico" tradicional está fundamentalmente equivocado e que deveria ser substituído por outro: um ensino baseado nas naturezas essenciais das hipóteses/teorias, das observações/experimentações e entre os dois tipos de previsão (retroativa e verdadeira), deixando explícito ao estudante ou ao público leigo o que cada um desses termos realmente significa, na teoria e na prática, para o cientista e para o filósofo da Ciência. É evidente que a argumentação não é definitiva e não proclama ser "a verdade", mas é uma das abordagens possíveis e certamente vai de encontro à visão de Ciência normalmente transmitida nos diversos veículos de divulgação e ensino. Apenas a menção de tal forma de ensino, em contrapartida à visão tradicional enraizada no empirismo e no positivismo, já poderia mudar sensivelmente a maneira como o público vê a Ciência, seus métodos e seus compromissos.

\section{6 - Ciência e Filosofia}

Em "O Grande Projeto", diz Stephen Hawking, um dos mais icônicos divulgadores da Ciência até o seu recente falecimento (em 2018), que "a filosofia está morta, tendo ela passado a 'tocha do conhecimento humano' para a Ciência" (2011, introdução). Ousada afirmação, que não só influenciou muitos dos professores e divulgadores posteriores, quanto ainda permanece no ideário de muitos deles. Não deixa de ser curioso o fato de que o livro em questão é, essencialmente, um livro de 
filosofia! Essa afirmação de Hawking parece, no mínimo, inadequada (o que soma a outros argumentos que utilizou ao longo da obra, que comentarei com mais detalhes no Capítulo III). Creio que a frase foi dita com o intuito de "radicalizar" e chamar a atenção, o que de fato foi conseguido, fazendo com o que o livro se tornasse um bestseller quase instantâneo. Infelizmente, esse tipo de atitude traz consequências não ditas que merecem ser explicitadas. Infelizmente, o caso envolvendo Hawking não foi isolado. Num excelente artigo analisando as ideias de Richard Feynman, afirmam Hoernig, Massoni e Lima (2020, p. 13) - e isso é algo que pude confirmar em minhas próprias investigações - que "existe uma parcela significativa de cientistas que considera que a filosofia da ciência não desempenha papel importante no desenvolvimento científico e por isso deve ser descartada".

"Paira no ar" o conceito de que a Ciência trata de conhecimentos "reais", "tangíveis", "comprováveis" e "comprovados", enquanto que a Filosofia trata unicamente de "especulações", "ideias vazias", "inúteis" e até mesmo de um "passatempo intelectual que não leva a nada"! Esse tipo de afirmação é compreensível quando parte de um leigo que até se interesse pelo saber científico, mas que possui pouca formação em geral - não só em Ciência como também na própria Filosofia. Mas é realmente notável que uma afirmação desse tipo parta justamente de um cientista considerado de primeira categoria, responsável por pesquisas de fronteira em Cosmologia, um dos mais avançados corpos teóricos da atualidade. Esse tipo de visão não é novo e pode ser sondado até suas primeiras manifestações notáveis com origens no positivismo (sim, novamente).

Para Comte, a Filosofia deveria ser uma mera subordinada das Ciências, resumindo sua atuação em classificá-las e ordená-las, devendo abandonar questões "irrelevantes", "desprovidas de sentido" e por pertencerem ao que ele chamava de os "estágios teológicos e metafísicos da civilização" (que, "obviamente", eram mais "atrasados" do que o "atual estágio científico"). Ele foi ainda mais além, ao dizer que a sua "filosofia positiva" deveria prevalecer e anular as filosofias "teológicas" e "metafísicas", pois é justamente a existência de diferentes filosofias (diferentes correntes filosóficas) a causa do "mal" e dos conflitos nas sociedades. Para ele, apenas a "filosofia positiva" deveria existir, por sua própria superioridade, e por ser o resultado natural da "evolução do entendimento humano" (ver primeira lição de seu Curso de Filosofia Positiva). Uma tese como essa foi, e ainda é, verdadeiramente 
subversiva no sentido pleno do termo: ela efetivamente subverte a relação que sempre existiu da Filosofia como origem e fonte da Ciência, sendo essa última a verdadeira subordinada da relação - uma concepção que remonta pelo menos a Aristóteles.

Diz o Estagirita em sua Metafísica (2002, Livro I, p. 13) que a Filosofia Primeira (a Metafísica), "de fato, entre todas [as ciências ${ }^{57}$ ], é a mais digna de honra" (ver discussão acerca da relação entre Ciência e Metafísica na próxima seção). Segue ele (Livro III, p. 95, [ ] meus):

"[...] se a ciência da substância [o que chamamos de "Física", "Química" etc.] é diferente da dos axiomas [a Filosofia], qual das duas será superior e anterior? Com efeito, os axiomas são o que de mais universal existe; e se não é tarefa do filósofo, de quem mais poderá ser a tarefa de indagar a verdade e a falsidade deles?"

São justamente esses axiomas que, nas Ciências, damos o nome de "Princípios". Os próprios conceitos basilares sobre os quais toda a Ciência se apoia são axiomas: não são empíricos de maneira alguma, ao mesmo tempo que, sem eles, a própria Ciência não existiria. Entram aqui inúmeros conceitos, sendo exemplos: o tempo, o espaço, a massa, a carga elétrica e até mesmo a vida. Somam-se a eles os Princípios mais universais a que Aristóteles se referia, como o Princípio da Causalidade e o que chamamos hoje de Princípio da Uniformidade (há ainda, em nossos dias, o Princípio Cosmológico, o Princípio Antrópico, o Princípio da Isotropia do espaço, e até o da Seleção Natural, como irei argumentar em uma seção posterior). Podemos incluir até mesmo certos compromissos de pesquisa, tais como o Naturalismo Científico. Esses conceitos são filosóficos em essência, metafísicos por excelência; é a própria Filosofia que Ihes confere valor e legitimidade, estabelecendo suas definições e seus limites. A Metafísica, conforme comentarei em detalhes mais à frente, não trata de assuntos "sobrenaturais", como leigos - letrados ou não costumam acreditar. Ela existe, sim, para investigar as causas mais profundas do mundo natural - ou seja, a busca pelas Causas Primeiras que dão origem à Física e às demais Ciências da Natureza em si mesmas. A Ciência sem a Filosofia é como um edifício sem o andar térreo ou uma árvore sem raiz.

Transmitir uma visão razoável sobre a relação existente entre Ciência e

57 No sentido de "campos de conhecimento". 
Filosofia não é fácil. Porém, um bom começo pode ser encontrado nas palavras de Bertrand Russell (História da Filosofia Ocidental, 1959, vol. 1, introdução):

"A filosofia, conforme entendo a palavra, é algo intermediário entre a teologia e a ciência. [...] entre a teologia e a ciência existe uma Terra de Ninguém, exposta aos ataques de ambos os campos: essa Terra de Ninguém é a filosofia. Quase todas as questões do máximo interesse para os espíritos especulativos são de tal índole que a ciência não as pode responder, e as respostas confiantes dos teólogos já não nos parecem tão convincentes como eram nos séculos passados. [...] O estudo de tais questões, mesmo que não se resolva esses problemas, constitui o empenho da filosofia. A ciência diznos o que podemos saber, mas o que podemos saber é muito pouco e, se esquecemos quanto nos é impossível saber, tornamo-nos insensíveis a muitas coisas sumamente importantes."

Os divulgadores de Ciência, seguindo a tradição de Carl Sagan ${ }^{58}$ de exaltação à Ciência, parecem se fascinar com os notáveis avanços e conquistas que ela nos proporcionou. Esse fascínio tende a nublar nossa visão com relação ao desconhecido; passamos a crer que sabemos muito; no último estágio, acabamos ignorando o alerta de Russell, esquecendo-nos do quanto nos é impossível saber. A insensibilidade que se segue nos afasta das questões importantes que a Ciência não alcança. É difícil ver algum ganho, mas é fácil ver muita perda, se tal insensibilidade continuar a ser propagada nos meios de divulgação.

A Ciência tem fornecido explicações magníficas acerca do mundo natural; mas, até o presente momento, a Filosofia ainda é superior para investigar as questões sociais e psicológicas que transformam o animal racional naquilo que denominamos de "humano". Mas não só isso: a Filosofia, sobretudo a Metafísica, continua sendo a fonte inesgotável de teorias candidatas a assumirem lugar no "panteão" das "teorias científicas". Por exemplo, estudiosos da Teoria da Evolução baseiam-se no princípio metafísico a priori de que não há "criador" e, portanto, não há um design direcionado (Sandino et. al, 2018, p. 74), enquanto que os defensores do Design Inteligente, tais como Dembsky, buscam fundamentar suas ideias em uma metafísica que assume um Criador Inteligente; os biólogos que, em geral, negam essa última metafísica acabam

\footnotetext{
${ }^{58}$ Falarei mais sobre a divulgação científica de Sagan no Capítulo III.
} 
por adotar a primeira ${ }^{59}$, e a pesquisa científica nessa área deve proceder como se a "ordem natural" fosse o mecanismo governante (ibid.). Esse é um claro exemplo em que a Metafísica assume protagonismo nas decisões de cunho metodológico e epistemológico da prática científica.

Por fim, é impossível fundamentar qualquer tipo de conhecimento sem uma epistemologia, sem uma Teoria do Conhecimento, que é, ao lado da Metafísica, o tema central da Filosofia, e não de qualquer outra disciplina.

Infortunadamente, existem inumeráveis exemplos de ataques abertos à Filosofia partindo de cientistas. Em entrevista à Folha de São Paulo (2018) ${ }^{60}$, o médico imunologista português António Coutinho, responsável por renovar e dar destaque ao Instituto Gulbenkian de Ciências (IGC), afirma que "Filosofia não é ciência e está fadada a desaparecer". Uma de suas falas é tão pitoresca quanto a afirmação de Hawking que abriu esta seção (os [ ] são meus):

"A ciência evolui no domínio das dúvidas, e não no domínio das verdades, da certeza absoluta, que é o domínio da religião. Como vamos excluindo as hipóteses que estão erradas, esta coisa avança, progride. Hoje sabemos mais do que há cem anos, há dez anos, do que no ano passado. Todo o resto da atividade humana não progride [?!]. Por isso a filosofia não é ciência, porque nunca progride [!!!]. Eu tenho o maior respeito pelos filósofos porque o objetivo da filosofia é o mesmo que o da ciência: explicar o mundo e a nós próprios. Agora, nós temos um bom processo e eles não têm, portanto estão fadados a desaparecer [?!]. O que é o objetivo da filosofia vai ser resolvido pela ciência, e a filosofia vai passar a história."

Essa entrevista é um retrato caricato, ainda mais do que O Grande Projeto, do cientificismo em si mesmo. É difícil não concluir que há algo de muito errado na maneira como nossos cientistas são formados (tema que abordarei no Capítulo III). Não é necessário comentar sobre a afirmação de que "todo o resto da atividade humana não progride", pois se trata de uma proposição vazia. Já afirmar que "filosofia não é ciência" pode ter muitos significados, mas certamente não é o (falso) fato de que "ela nunca progride" que determina isso. A Filosofia não só progride, como

\footnotetext{
59 Há ainda a posição mais conservadora do agnosticismo, que suspende o julgamento e guarda a dúvida sobre qual das duas metafísicas seria a correta, se é que uma delas seria. Ver o artigo citado, p. 74, onde essa posição é defendida como a mais adequada.

${ }^{60}$ Disponível em https://www1.folha.uol.com.br/ilustrissima/2018/06/filosofia-nao-e-ciencia-eesta-fadada-a-desaparecer-afirma-pesquisador.shtml, consultado em 30/12/2019.
} 
progrediu tanto que permitiu a existência da Ciência, e permanece até hoje sendo a origem do embasamento do conhecimento científico. Não existe Ciência sem Filosofia. O que existem são cientistas que ignoram ou desconhecem a epistemologia filosófica que faz com que suas teorias, e mesmo os testes empíricos, não sejam apenas um amontoado de entulho sem propósito. É a Teoria do Conhecimento, e somente ela, que faz com que o saber científico não seja um "trono de pó" ou um "castelo de cartas". Dizer que a Filosofia está fadada a desaparecer é uma profecia que só pode ser proclamada por alguém que não entende absolutamente coisa alguma de Filosofia. Que o objetivo da "Filosofia vai ser resolvido pela Ciência" é discutível, mas (1) é a Filosofia que fornece as ferramentas para que a Ciência possa talvez realizar tal proeza e (2) isso apenas liberará a Filosofia para dar ainda mais contribuições em campos antes desconhecidos e inacessíveis, estando sempre à frente, e não atrás, do avanço científico. No mais, acreditar que a Ciência pode vir a substituir uma outra área qualquer do conhecimento é cientificismo ${ }^{61}$ puro e simples (Haack, 2012, p. 92). Deveria ser claro que a Filosofia investiga os aspectos mais gerais e universais daquilo que chamamos de "realidade". É verdade também, como já dito, que a Filosofia não está limitada pela observação empírica, podendo ir mais a fundo e não investigar apenas o que "é" mas podendo indagar e até mesmo prever aquilo que "pode ser". E, de fato, aí reside um dos maiores méritos da Filosofia: em suas investigações do que "pode ser", ela acaba prevendo muito do que, efetivamente, mais tarde se mostra "ser de fato". E é nesse momento que aquele conhecimento abstrato, remoto, metafísico, que pertencia à Filosofia, acaba se estabelecendo como parte de uma Ciência específica, deixando apenas os seus resíduos para trás. Sobre essa característica residual da Filosofia, Russell brilhantemente sintetiza (Os Problemas da Filosofia, 2012, p. 173, [ ] meus):

"(...) um filósofo [irá] confessar, se for sincero, que a filosofia não alcançou resultados positivos como os que foram alcançados em outras ciências. É verdade que isso se explica, em parte, pelo fato de que, assim que se torna possível um conhecimento preciso naquilo que diz respeito a determinado assunto, este assunto deixa de ser chamado de filosofia e tornase uma ciência especial."

${ }^{61}$ Dedicarei ainda muito espaço para discutir essa questão do cientificismo mais adiante. 
Depois disso, a impressão que fica para aquele que começa a aprofundar os seus estudos em Filosofia (ou mesmo para alguém que possua apenas um conhecimento superficial dela) é de que ela jamais conseguiu resolver problema algum (ou mesmo que ela jamais tenha posto sobre a mesa algum problema que fosse realmente relevante). Essa tarefa ingrata, ao mesmo tempo que maravilhosa para os que se dedicam a ela, é traduzida sinteticamente por Popper no prefácio à $1^{\text {a }}$ edição (1934) d'A Lógica (1993, p. 23): "[O filósofo] não se coloca diante de uma estrutura organizada [como o faz o cientista], mas, antes, em face de algo que semelha um amontoado de ruínas (embora, talvez, haja tesouros ocultos)".

O próprio "sabor" de liberdade da Filosofia faz com que os seus praticantes possam, a cada nova geração, "demolir" o que a geração anterior construiu (originando o que Popper chamou de "amontoado de ruínas"). Aqui temos, portanto, mais uma demonstração do poder da Filosofia: ela abre os caminhos da Ciência, mostrando primeiramente todos os mundos possíveis, para que, posteriormente, o mundo "real" possa ser identificado dentre todas as possibilidades preditas. Foi esse fato que levou Russell a afirmar (2012, p. 166) que "(...) enquanto nosso conhecimento do que é tem se tornado menor do que inicialmente se imaginou, nosso conhecimento do que pode ser aumentou muito". E, por fim, a demolição realizada pelas novas gerações não é literal: as filosofias das gerações anteriores continuam sendo válidas em seus contextos, e estão sempre disponíveis para serem estudadas, podendo ter seus tesouros redescobertos e reinterpretados à luz dos modernos avanços da Ciência. Muitos dos conceitos filosóficos são atemporais e permanecem válidos milênios depois de formulados.

Muito significativa é a seguinte afirmação de Popper (2013, p. 535):

"Eu, entretanto, acredito que exista pelo menos um problema filosófico no qual todos os homens de cultura estão interessados. É o problema da Cosmologia: o problema de compreender o mundo - inclusive nós próprios e nosso conhecimento como parte do mundo. Segundo entendo, toda ciência é Cosmologia e, para mim, o interesse que tem a Filosofia, assim como o que tem a Ciência, reside apenas nas contribuições que elas trazem para a Cosmologia. Tanto a Filosofia como a Ciência perderiam, a meu ver, todo o atrativo, se abandonassem esse alvo." 
Frente a uma afirmação profunda como essa, vemos o grande equívoco que é "decretar a morte" da Filosofia. Popper ainda nos fornece um argumento a mais (2013, p. 548):

"[...] há um argumento em favor da Filosofia. Em suma, todas as pessoas têm a sua filosofia, saibam disso ou não. Dê-se de barato: não é grande coisa o que valem tais filosofias. Todavia, a influência que elas exercem sobre nosso pensamento e sobre nossos atos é, frequentemente, devastadora. Por esse motivo, torna-se preciso examinar nossa filosofia com olhar crítico. E esta é, justamente, a sua missão — e aí está sua defesa."

Mesmo contando apenas com a brevidade dessa análise e dessas escassas citações, já deveria ser simples reconhecer a ausência de fundamento na suposta "morte da filosofia" dada a cabo por Hawking. Infelizmente, o estrago já foi feito. Esse tipo de ideia não é exclusividade do falecido cientista, mas permeia muito da divulgação e da educação científica atual. É, como já dito, uma característica marcante do cientificismo, abordado em mais detalhes logo adiante. Lamentavelmente, tendo em vista o panorama brasileiro do ensino tanto de Ciências como de Filosofia nas escolas e até mesmo nos cursos universitários de formação científica, trabalhar para reverter esse quadro é uma tarefa sumamente difícil.

\section{7 - Ciência e Metafísica}

Metafísica é um conceito certamente mal compreendido por muitos. A sua real concepção vem da Filosofia, campo onde relativamente poucos se aventuram com seriedade e profundidade. Acaba predominando, neste caso, visões errôneas, verdadeiros espantalhos, usados tanto para defender as ideias mais infundadas quanto para desqualificar tudo o que se acredita estar debaixo de seus domínios. Há aqueles, como já dito anteriormente, que consideram mesmo que a Metafísica é "inútil" e "desprovida de sentido". É possível chegar a essa conclusão. Mas, ao meu ver, e nisto tenho o apoio de Popper, Kuhn e dos maiores filósofos da história, trata-se de uma conclusão equivocada motivada por (1) desconhecimento da real natureza da Metafísica, por (2) influência positivista, ou por uma combinação de ambos. 
Com relação à influência positivista, é um caso curioso que ela continue tendo tanta força fora do meio acadêmico, enquanto que academicamente é uma visão efetivamente refutada. Notável é o caso de um conhecido e influente divulgador de Ciência (comentado no Capítulo III) que disse ao próprio (e numeroso) público que "se considera positivista". Popper, Kuhn, Lakatos, Laudan... Todos esses filósofos da Ciência trataram de demonstrar que a ideia positivista é ingênua, além de lógica e epistemologicamente infundadas. Dizem Laudan e colaboradores (Laudan et al., 1993):

"No início dos anos 60, algumas novas teorias da ciência foram desenvolvidas como alternativas ao positivismo; trata-se dos trabalhos de N.R. Hanson, Paul Feyerabend, Stephen Toulmin e, acima de tudo, Thomas Kuhn. Essas contribuições, ainda que problemáticas em suas teses positivas, puseram termo efetivamente à hegemonia do positivismo ao revelarem que suas doutrinas centrais (tais como a cumulatividade da ciência, a redutibilidade da linguagem teórica à observacional) conflitam radicalmente com a prática real da ciência."

Existem ainda muitos outros argumentos lógicos e epistemológicos contra o positivismo, mas creio que a citação acima seja o suficiente para demonstrar que desconsiderar a Metafísica com base no positivismo é algo desprovido de fundamento. Já o desconhecimento da real natureza da Metafísica exige um maior aprofundamento.

Aristóteles definiu a Metafísica como a busca dos princípios primeiros ou axiomas (ver o livro IV de sua Metafísica). Esse é o norte que orientou todos os filósofos posteriores que desenvolveram sistemas metafísicos. Embora a Metafísica de cada um tivesse o seu "sabor" particular, tanto a Mente Universal de Berkeley, a Mônada de Leibniz, o Absoluto de Schelling, e tantos outros metafísicos, dos présocráticos aos neoplatônicos, de Descartes a Kant etc., eram apenas espécies de um mesmo gênero: a definição aristotélica da Metafísica. Portanto, a Metafísica, em seu bem empregado sentido filosófico, tem bem pouca dependência com questões "sobrenaturais", "misticismos quânticos" etc., sendo que essas seriam, no máximo, metafísicas especiais, conviventes com tantas outras, e não representantes definitivas do sentido original. Os Princípios Primeiros da Metafísica tratam mesmo do mundo natural. Aristóteles, em sua Metafísica, quis investigar as causas da substância e de seus acidentes (suas "características sensíveis", que são, no fundo, o objeto de estudo 
das Ciências da Natureza), além da propriedade da existência mesmo, do ser (ontologia), das substâncias, a origem da geração e da corrupção delas etc.

Diz Popper sobre a influência histórica da Metafísica na Ciência (2013, p. 540):

"É um fato que as ideias puramente metafísicas - e, portanto, as ideias filosóficas - têm-se revelado da maior importância para a Cosmologia62. De Tales a Einstein, do atomismo antigo às especulações de Descartes acerca da matéria, das considerações de Gilbert, Newton, Leibniz e Boscovic, a propósito das forças, às de Faraday e Einstein a respeito de campos de forças - a Metafísica sempre indicou rumos."

Ainda com relação a Popper, o mais notável é que ele propôs uma divisão entre Ciência Empírica e Metafísica com seu critério de falseabilidade, mas sem a intenção que tantos tiveram (e outros tantos ainda têm) de aniquilar a Metafísica. Diz ele (ibid., p. 346):

"Efetivamente, nosso critério de falseabilidade estabelece uma distinção suficientemente precisa entre os sistemas teóricos das ciências empíricas e os sistemas da Metafísica (e sistemas convencionais e tautológicos) sem, contudo, asseverar que a Metafísica é destituída de sentido (recordando que, sob uma perspectiva histórica, a Metafísica pode ser vista como a fonte de que brotam as teorias das ciências empíricas)."

Kuhn também não se posicionou contra a Metafísica quando relata diversos casos históricos de teorias científicas que foram aceitas muito antes de poderem ser empiricamente verificáveis (entre elas as Leis de Newton e o atomismo de Dalton).

Em realidade, toda a nossa Ciência atual é embasada por princípios metafísicos. Queiram os cientistas aceitar esse fato ou não, eles seguirão fazendo o uso do "Princípio da Causalidade" (a busca por regularidades e leis na natureza), do "Princípio da Uniformidade" (a consideração de que as leis da natureza permanecem as mesmas ao longo do tempo) e de tantos outros "Princípios" que são, por

${ }^{62}$ Como pode ser conferido nos parágrafos anteriores a esse n'A Lógica, Popper utilizou o termo Cosmologia não apenas para se referir ao estudo da origem e evolução do Universo, mas para todo o conhecimento científico e filosófico referente à natureza do mundo. Em resumo, refere-se ao conhecimento mais geral que a Ciência e a Filosofia podem nos proporcionar. 
excelência, metafísicos. Miriam Joseph, em O Trivium ${ }^{63}$, afirma que (2008, p. 257, [ ] meus):

"Este último princípio [da causalidade] é um axioma filosófico, cognoscível pela indução intuitiva. Axiomas filosóficos são verdades necessárias metafisicamente. Os postulados da ciência não o são, e, portanto, não têm um grau de certeza tão elevado."

Popper também faz essa distinção entre "verdades necessárias metafisicamente" como sendo aquelas que, sem a sua existência, não seria possível um mundo concebível. Com relação a elas serem "cognoscíveis pela indução intuitiva", isso é um ponto a se debater. Alguns considerariam que "indução intuitiva" é apenas outra forma de dizer "pura fé". No fundo, não faz diferença - o Princípio continua sendo o que é. Especialmente sobre o Princípio da Causalidade (o qual ressurgirá recorrentemente neste trabalho), disse Popper (1993, p. 271):

"O mundo é ou não regido por leis estritas? Entendo que essa questão tem cunho metafísico. As leis que estabelecemos são sempre hipóteses, querendo isso dizer que sempre podem ceder passo a outras e que podem ser deduzidas de estimativas de probabilidade. Não obstante, negar a causalidade equivaleria a tentar persuadir o teorizador a abandonar a investigação. Já se mostrou que uma tentativa dessa ordem não pode apoiarse em coisa alguma que se ponha como uma demonstração. O chamado "princípio causal", ou "lei causal", seja qual for a formulação que receba, tem caráter muito diferente do caráter de uma lei natural [...]."

Na página seguinte, Popper é categórico: "a crença na causalidade é metafísica". É isso que, ainda segundo Popper, faz o cientista não abandonar jamais a busca de leis. Afinal, se ele as abandonar, o que mais fará? Isso seria tão absurdo quanto o marceneiro abandonar a madeira, ou o remador abandonar o remo!

É impossível exterminar a Metafísica como sonhara Comte. Fazer isso significaria acabar com a própria Filosofia, com os conceitos transcendentais (o bom,

${ }^{63}$ Houve, no século XX, por parte do filósofo norte-americano Mortimer Adler (1902-2001) e de seus discípulos, a iniciativa de se revitalizar as Sete Artes Liberais Clássicas. Em especial, o trivium (gramática, lógica e retórica) recebeu um grande impulso com a publicação de $O$ Trivium (2002) por uma das alunas de Mortimer, a irmã Miriam Joseph (1898-1982). A publicação post mortem era o resultado de um curso de trivium que Joseph ministrou por vinte e cinco anos para ingressantes no curso de jornalismo e outras áreas no Saint Mary's College, uma instituição de ensino superior do estado de Indiana - EUA. A obra é essencialmente aristotélica e é uma grande e sólida iniciação ao mundo da Filosofia. Ver referências. 
o belo, o justo), com a principal fonte de novas teorias científicas e com a própria base sobre a qual estas se assentam.

Que os divulgadores e educadores de Ciências, assim como os jovens cientistas em treinamento não mais teçam argumentos injustos à Metafísica. ${ }^{64}$

\section{8 - Ciência e Fé}

Em meu trabalho como professor de Ciências no ensino médio, uma pergunta peculiar a mim é feita com frequência pelos alunos: "Professor, você acredita em Deus?". Evito responder tal pergunta (assim como não me ocuparei dela no presente trabalho), mas quero chamar atenção para as respostas que me dão esses mesmos alunos quando lhes questiono o porquê de estarem perguntando isso. As duas respostas mais comuns (com ligeiras variações) são: (1) "Porque você 'é da Ciência' [sic], né?" (querendo dizer que se alguém "é da Ciência", teria algum problema particular com a crença [ou não crença] em Deus) e (2) "Porque quem 'acredita' na Ciência não acredita em Deus!" (fazendo uma clara e falsa dicotomia entre Ciência e teísmo).

Dessa pequena, mas significativa, constatação, podemos ver presente um conceito comum, embora errôneo e distorcido, acerca dos domínios da Ciência e da fé. Esse tópico por si só renderia volumes inteiros. Por isso, irei apenas analisar brevemente os pontos centrais que se encontram dentro do escopo desta dissertação ${ }^{65}$.

\footnotetext{
${ }^{64}$ A presente dissertação é também uma contundente defesa da Metafísica e de seu papel indispensável na Ciência. Retornarei a esse tema muitas vezes, sempre ampliando e aprofundando o quão necessária ela é e o tanto que está presente em nossa Ciência atual.

65 Um tratamento específico da relação entre Ciência e Religião, assim como possíveis abordagens em sala de aula, pode ser encontrado na dissertação de mestrado do prof. Bagdonas (Henrique, 2011). No presente tópico, meu objetivo é tratar a discussão sob outro ângulo: dedico-me a explorar filosoficamente o conceito de fé, para então entender qual o seu papel na epistemologia e, por consequência, no fazer, no ensinar e no divulgar da Ciência (é por isso que o tópico foi chamado de "Ciência e Fé", e não "Ciência e Religião"). No entanto, deixo claro que estou alinhado com a visão do prof. Bagdonas, quando ele diz (op. cit., p. 144): "Acreditamos que os professores de ciência não devem evitar a discussão sobre as relações entre ciência e religião em sala de aula, uma vez que ela pode ser muito rica para
} 
Em primeiro lugar, o senso comum tende a associar automaticamente fé com o domínio religioso. Isso é verdadeiro não apenas para leigos, como também para cientistas que possuam a visão distorcida de que a Ciência está em um nível superior e, portanto, liberta das "amarras da fé" (aqui tratada pejorativamente, como se fosse uma espécie de obscurantismo). Uma frase famosa atribuída a Carl Sagan é "Eu não quero acreditar, eu quero conhecer". Esse tipo de pensamento se dá por, frequentemente, se ignorar o papel da fé em cada ação da vida diária, mesmo na menor e mais insignificante delas.

Fé, em uma primeira definição simples e longe do monopólio teológico, é tão somente aceitar algo sem tê-lo visto por nós mesmos ${ }^{66}$. Dessa forma, quando estudamos uma teoria científica em um livro, antes de termos verificado experimentalmente (ou deduzido matematicamente, ou como quer que seja a natureza do conhecimento em questão) temos fé de que aquele conhecimento é real, exatamente da mesma maneira como acreditamos em um relato dado por uma pessoa próxima que julgamos ser honesta e minimamente lúcida para não ter se equivocado. Kuhn afirma (2012, p. 163) que "(...) os estudantes de ciência aceitam as teorias por causa da autoridade do professor e dos textos e não devido às provas. Que alternativas, que competência possuem eles?".

Mesmo uma pessoa com sede apenas bebe água pela fé que tem no poder daquela água em saciar a sensação incômoda. Especialmente neste último exemplo, vê-se que a fé não é algo baseado em "nada" ou em "puro achismo", mas que necessita de um fundamento: de tantos copos d'água tomados na vida com o mesmo efeito "saciador", a pessoa tem fé absoluta (ao nível de "certeza absoluta") de que o próximo copo d'água irá saciá-la exatamente da mesma forma que os anteriores. Isso nos leva, novamente, ao Problema da Indução: é impossível deduzir logicamente essa conclusão, por maior que seja a sensação de certeza que tenhamos dela, e não importa quantas experiências de "beber água" tenhamos acumulado. E é aqui que começa a ser esboçada a presença da fé no campo científico, pois essa crença no efeito "saciador" da água, baseando-se no acúmulo de experiências passadas, é análoga ao já citado Princípio - integralmente adotado pela Ciência - da Uniformidade da Natureza: as leis naturais permanecem as mesmas, imutáveis, ao

expor melhor as visões dos alunos sobre a ciência, permitindo-lhes perceber as diferenças entre o conhecimento científico e outras formas de ver o mundo".

${ }^{66}$ Ao longo da seção, tal definição será problematizada. 
longo do tempo. Ora, mas essa é uma ideia Metafísica, impossível de ser comprovada empiricamente, forçando-nos a aceitá-la unicamente por fé!67 Mas não se trata, de forma alguma, de uma "fé cega", mas sim de uma fé em algo que nos transmita confiança, que pareça fazer sentido e que não contradiga flagrantemente nossas experiências pessoais. Tudo isso está de acordo, em grande parte, com nosso julgamento racional. Voltarei a esse ponto logo adiante.

Discorrendo acerca do grau de certeza de que o "sol nascerá amanhã" e que "velhos experimentos jamais conduzem a novos casos futuros" (Popper, 1912, p. 274), diz Popper (p. 277, [ ] meus):

"Pode-se admitir que seja concebível (ou logicamente possível) que tais regularidades venham a alterar-se; mas essa possibilidade é desconsiderada pela ciência empírica, e não the afeta os métodos. Pelo contrário, o método científico pressupõe a imutabilidade dos processos naturais, ou seja, pressupõe o 'princípio da uniformidade da natureza'. O argumento expressa fé metafísica [!] na existência de regularidades em nosso mundo (uma fé de que partilho [!!!] e sem a qual dificilmente se poderia conceber uma ação prática)."

Tal parágrafo popperiano é sozinho capaz de demolir todas as falas cientificistas que contrapõem fé e Ciência, falas essas que tanto abundam nos meios de divulgação e na mídia em geral. Mesmo a fala de Sagan é completamente esvaziada quando percebemos que o "conhecer" dele seria completamente impossível na ausência do "acreditar".

Porém, novamente, a fé neste caso está embasada em um longo histórico de observações empíricas. É verdade que o sol pode não nascer amanhã. Mas temos um sentimento psicológico de convicção tão grande de que ele irá, de fato, nascer (como o fez, no mínimo, ao longo de toda a história registrada), que nem levamos em consideração a possibilidade contrária. Mas existe algum tipo de fé que não possua base alguma? Creio que não68. Ao contrário: qualquer tipo de fé adotada por alguém, seja uma fé religiosa ou de qualquer outra procedência, está embasada, em

${ }^{67}$ E isso também está intimamente relacionado ao Problema da Indução e em por que Popper e outros antes dele tanto buscaram resolvê-lo: não há meio lógico para se inferir uma conclusão universal partindo de casos particulares. A conclusão universal de que "todo copo d'água irá saciar minha sede" só pode ser sustentada por fé, de acordo com o argumento que utilizei nesse parágrafo.

${ }^{68}$ Com exceção de pessoas que concretamente sofram de distúrbios mentais e cognitivos. 
significativa proporção, na razão. A isso, os estudiosos da lógica (incluso Popper) chamavam de "racionalidade da crença". Se a fé não possuísse nenhuma base racional, por que alguém acreditaria em um deus ou em um conjunto de deuses, ao invés de, por exemplo, crer no "coelhinho da páscoa", na "fada do dente" ou no "papai Noel"? É evidente que a pessoa analisa racionalmente as implicações de cada opção de crença que the é apresentada, decidindo por acreditar naquilo que faz mais sentido para si, o que certamente passa, em grande medida (mas não só, evidentemente), por um julgamento racional. Russell (1957, p. 151) sintetiza essa concepção ao dizer: "Devo acreditar naquilo em que creio devido a alguma razão me levar a isso".

Agora abordando a questão por outro lado, de uma forma que seja mais incisiva aos que creem em uma "Ciência liberta da fé", vejamos a seguinte citação de Kuhn (2012, p. 258, [ ] meus):

"O homem que adota um novo paradigma [uma nova teoria, como quando foram sugeridas a Evolução ou a Relatividade] nos estágios iniciais de seu desenvolvimento frequentemente adota-o desprezando a evidência fornecida pela resolução de problemas. Dito de outra forma, precisa ter fé na capacidade do novo paradigma para resolver os grandes problemas com que se defronta, sabendo apenas que o paradigma anterior fracassou em alguns deles. Uma decisão desse tipo só pode ser feita com base na fé."

Há ainda a questão de se crer que a Ciência é a responsável por trazer à tona a única explicação possível, correta e completa, acerca de qualquer questão. Para muitos dos que adotam essa crença, que podemos chamar de "realismo ingênuo", é mera questão de tempo para que a Ciência resolva qualquer enigma que o Universo nos apresente, mesmo os mais remotos, profundos e inimaginados. Sobre isso, diz lan Haking em seu Ensaio Introdutório à Estrutura (Kuhn, 2012, p. 43):

"O pensamento segundo o qual há uma e somente uma explicação verdadeiramente completa de tudo está profundamente enraizado na tradição ocidental. Ele descende daquilo que Comte, o fundador do positivismo, denominava 'o estágio teológico da investigação humana'. (...) Essa imagem é transportada para a física básica, na qual muitos dos profissionais, que se autodenominam orgulhosamente ateus, dão como certo haver, esperando para ser descoberta, uma explicação plena e completa da natureza." 
Até Comte rejeitava essa posição, mas muitos divulgadores e professores, mesmo aderindo em geral à visão positivista, seguem propagando tal ideia ${ }^{69}$. É claro que qualquer cientista, como qualquer indivíduo, deve ter a liberdade para pensar dessa maneira se assim Ihe aprouver. Há cientistas ateus, guiados por motivações puramente materialistas (afinal, eles têm a fé não admitida de que o mundo físico é tudo o que existe ${ }^{70}$ ), enquanto outros sustentam sua própria religião, por vezes deixando mesmo que ela tenha forte influência em sua atividade investigativa. $O$ erro está em atribuir essa decisão à Ciência, como se fosse uma característica intrínseca a ela, e como se a adoção dessa mesma linha de pensamento fosse um requisito para participar do meio científico. Essa concepção materialista foi defendida, de fato, por Mahner e Bunge (1996, p. 189), ao afirmarem que a Ciência não pode prescindir de tal posição. Em realidade, esse pensamento é apenas mais um tipo de fé, no qual, ao tentar fugir de todos os outros, o cientista-cientificista acaba atrelado como o está à própria sombra. Mais uma vez: Não há meio de justificar qualquer teoria científica/empírica que não por postulados metafísicos e epistemológicos aceitos como verdadeiros a priori por meio da fé.

Devo concordar com Poole (1996, p. 170) quando este afirma que não há incompatibilidade intrínseca entre Religião e Ciência. E isso por dois motivos essenciais: (I) nosso conhecimento total, seja de origem científica ou religiosa, é sempre muito pouco e é inexoravelmente dependente da fé, de forma que a natureza última de ambas as formas de conhecimento se sintetiza no mesmo princípio, e (II) é possível praticar ambas as modalidades sem permitir que os princípios de uma tentem se sobrepujar e anular os da outra, tal como efetivamente trabalham e trabalharam inúmeros cientistas religiosos do presente e do passado. É plenamente possível uma convivência harmoniosa, desde que não haja tentativas de interferência direta e autoritária.

Comte buscou exterminar a teologia e a metafísica, crendo ser possível excluí-

\footnotetext{
${ }^{69}$ Mais adiante, comentarei um caso específico de divulgação recente em que o divulgador afirma que, caso perdêssemos todo o nosso atual conhecimento científico, o reconstruiríamos exatamente da mesma forma como ele é hoje. É o mesmo que afirmar que existe apenas "uma explicação verdadeiramente completa de tudo". Sobre o quão presente é essa visão entre educadores de Ciência, pode-se ver Bisch (1998). Apesar de ser uma tese defendida há mais de vinte anos, pouca coisa mudou na crua realidade da sala de aula e dos livros didáticos.

$70 \mathrm{O}$ argumento é: eles assumem que o mundo físico é tudo o que existe, mas sem admitir — em alguns casos, sem nem ao menos perceber — que isso é apenas mais um tipo de fé.
} 
las completamente do meio científico ("positivo"). Tal empreendimento é impossível, como já demonstrado (ver, por exemplo, a citação de Popper acima sobre "fé metafísica"). O próprio Popper afirma, e isso é algo que busquei sustentar na seção anterior, que as tentativas de aniquilar a Metafísica levariam consigo toda a Ciência para o mesmo fim.

A teologia grega afirmava que seus deuses, especialmente os das primeiras gerações de acordo com Hesíodo em sua Teogonia, eram personificações das forças e dos elementos primordiais da natureza. Tirando o fato de que os gregos não estavam tão preocupados com verificações empíricas, vemos ainda os resíduos teológicos dessa antiga visão quando afirmamos que todas as "leis da natureza" são governadas por quatro (ou três, ou quantas sejam) "forças fundamentais", ou que toda a matéria é constituída de "partículas elementares", ou ainda de "massa e energia" etc. Tais conceitos primordiais, sobre os quais todo o edifício da Ciência é erguido, como já dito, têm caráter de axiomas: não são passíveis de demonstração. Ainda há, entre divulgadores e educadores, a ideia de que em Ciência tudo que é "científico" (com isso querendo dizer: tudo o que é "real") é observável e passível de demonstração.

Com relação ao que é observável, é tão somente um resíduo positivista que, em partes, já foi superado: muito do que a Ciência hoje aceita não é, por definição, observável (por exemplo, as partículas virtuais de interação na Mecânica Quântica). Com relação à demonstração, já na sua Metafísica, no livro IV, afirmou Aristóteles a impossibilidade de se encontrar demonstrações para tudo, sob pena de cair em uma indesejável regressão infinita. Então, sem o recurso da demonstração, que outro meio temos para aceitar princípios axiomáticos senão pela fé? Se cobrarmos uma demonstração definitiva para todas as coisas, seremos obrigados a abandonar os axiomas fundamentais da Ciência (que, por natureza e mais uma vez, estão além de toda demonstração) e, com isso, toda a Ciência viria abaixo. Isso é absurdo e, de fato, não acontece, a despeito de toda a depreciação que o cientificismo, muito ignorante nesse aspecto, demonstra pela fé.

Após essa breve exposição, creio [!] estar suficientemente clara a impossibilidade de "libertar-se" completamente da fé. Esse ideal embasa uma das principais distorções científicas responsáveis por afastar estudantes e leigos da Ciência - o já citado cientificismo. Em geral, é muito difícil para um ser humano 
(incluindo, é claro, o cientista ${ }^{71}$ ) suportar que suas crenças, sua fé, sejam atacadas frontalmente. E é justamente nesse ponto onde os maiores divulgadores da Ciência do século XX (Dawkins, Sagan, Hawking), e muitos professores, não tomam o devido cuidado em suas exposições. O resultado é uma visão falsa de "Ciência ateia"72, ou de "Ciência como superação definitiva de crenças", que apenas atrairá para o meio científico mais pessoas alinhadas ao cientificismo, e tenderá a afastar as visões mais amplas do que é a Ciência. O positivismo, apesar de lógica e racionalmente refutado, permanece firme no imaginário do leigo e do cientista, e não parece que tal realidade irá mudar tão cedo.

\section{9 - Sobre o Termo "Ciência Empírica"}

Durante todo o meu período de graduação, ouvi dos professores que a "Física é uma Ciência Experimental". Com isso, é evidente, queriam dizer que ela é uma Ciência Empírica ${ }^{73}$. Pois bem. Perguntemos: sendo a Física uma Ciência Experimental, por qual motivo a carga horária destinada a disciplinas puramente teóricas é esmagadoramente maior do que a destinada às disciplinas de laboratório? E por que todas as aulas de laboratório começam com uma exposição das bases teóricas que embasam o experimento que será realizado? Por que todo relatório científico começa com a exposição dessas mesmas bases teóricas?

Nunca me ocorreu de realizar esses questionamentos em sala de aula. Também nunca vi nenhum colega, seja da licenciatura ou do bacharelado, questionar esse ponto. Mas não seria de interesse maior aos próprios professores indagarem

\footnotetext{
${ }^{71}$ Repito isso devido à grande facilidade que há em se esquecer de que o cientista é humano! Se apenas esse fato nunca deixasse nossa consciência quando analisamos as questões que orbitam o meio científico, é possível que estivéssemos muito melhor protegidos contra as visões distorcidas de que tanto faço menção.

72 Sobre a relação entre Ciência e a fé religiosa, a posição mais segura para um verdadeiro cético é a de que a Ciência não deve ser utilizada nem para negar e nem para confirmar qualquer religião, sendo a escolha por uma religião ou outra (ou nenhuma) um julgamento de cada indivíduo (cientista ou não).

${ }^{73}$ O termo "experimental" é mais ambíguo do que o termo "empírico" (pensemos, por exemplo, quando dizemos sobre "arte experimental"), embora no caso relatado fique claro que aqui tratam-se de sinônimos.
} 
seus alunos acerca disso? Não deveria partir deles a iniciativa de levar seus alunos a questionar? Francamente falando, creio que grande parte dos professores também nunca fizeram essa pergunta. Alguns, de fato, não demonstravam saber muito mais do que resolver exercícios (ou, se sabiam, escondiam muito bem). Eles reproduziam em suas aulas aquilo que eles mesmos receberam como treinamento prévio: assumir conhecimentos, mas não indagar acerca da validade, ou mesmo da verdade, ou da realidade dos mesmos. Tentarei agora então responder àquelas perguntas iniciais, assim como demonstrar a importância dessa discussão.

Começo com um questionamento, confesso, estranho: seria a culinária uma "Ciência Empírica" ou "Experimental"? Respondo com outra pergunta: por que não seria? Há técnicas das mais sofisticadas para tentar desenvolver os melhores pratos, os sabores mais exóticos e refinados, todos obtidos através do esforço, da experimentação, da transmissão de saberes através das gerações etc. A culinária é essencialmente prática, baseada em testes empíricos: o aspecto geral do prato, a sua cor, suas texturas, seu aroma, sua temperatura... Tudo isso importa e tudo isso constitui informação empírica. Logo, voltando ao questionamento inicial, a culinária é uma Ciência Empírica? Muitos responderiam de imediato um "não", talvez por simplesmente a culinária "não parecer" com Física ou com Química. Mas, em que sentido não parece? Como mensurar isso? Outros poderiam responder dizendo que as Ciências Empíricas estudam a Natureza, enquanto que a culinária é uma artificialidade criada pelo ser humano (com isso querendo dizer que não seria "natural"). Mas o ser humano é alguma coisa que não um membro da Natureza? Existe algum utensílio utilizado em culinária que não tenha sido extraído e elaborado com substâncias da Natureza? É, por acaso, o alimento algo não-natural? Provavelmente, teríamos também aqueles que diriam que a culinária não pode ser uma Ciência Empírica, pois o principal objetivo dela é apenas agradar ao (paladar do) ser humano, enquanto que a Física e as demais Ciências da Natureza visam a ampliação do conhecimento e a melhoria de nossas condições materiais.

Devo discordar desse último ponto. As Ciências da Natureza visam, sim, agradar ao ser humano. Não me refiro ao domínio sobre o mundo natural e avanço tecnológico. Uma descoberta científica normalmente não gera nenhum avanço tecnológico de imediato (algumas, talvez, nunca gerarão - simplesmente não há como saber). Cientistas buscam conhecer pelo prazer intelectual e pela alegria de 
conhecer. Muitos cientistas, incluindo alguns ateus e agnósticos (Sagan, por exemplo), relatam o sentimento de maravilha e até de elevação espiritual ao contemplar, estudar e compreender o Universo. Alguns dos melhores professores e divulgadores são justamente aqueles que conseguem servir ao seu público com grandes doses desse sentimento de assombro e contemplação.

Nós, que buscamos a Ciência, compartilhamos, em maior ou menor grau, desse mesmo sentimento. Se riqueza ou fama fossem mais importantes para nós, certamente teríamos escolhido outro caminho. A satisfação, a experiência desse êxtase do saber, é o motor que guiou os grandes cientistas da história. Então, sim, a Ciência visa, antes de tudo, satisfazer ao ser humano, torná-lo mais feliz. Afinal, vencido o desafio da sobrevivência, não é a busca pela felicidade a mais natural, atemporal e universal inclinação de nossa natureza? Então, até nisso a culinária se assemelha às Ciências da Natureza! Por caminhos diferentes, ambas visam a felicidade humana. Alguns acreditam que a Ciência irá encontrar a "cura" para a tristeza ou para a doença da depressão. Eu acredito que o próprio estudo da Ciência pode, se não nos curar, ao menos nos insuflar de esperança e atenuar nossos pesares através da contemplação de algo que é maior do que nós mesmos: a Natureza, o Cosmo, o mistério da existência.

Assim sendo, após toda essa digressão, só resta por concluir que não é o fato de realizar testes empíricos o diferencial das Ciências Naturais. Outras tantas ciências ou artes dependem vitalmente do teste empírico. O grande diferencial das Ciências Naturais está em seu corpo teórico. Nas palavras de Krause (Tópicos em Ontologia Analítica, 2017, p. 183):

"Basta que reconheçamos que a atividade científica é uma atividade conceitual. O biólogo [...] utiliza noções (conceitos) como as de espécie, ambiente, $\mathrm{pH}$ da água, etc.; o físico que estuda buracos negros vale-se dos conceitos da relatividade geral, enquanto que o economista utiliza as noções como a de mercado e demanda, dentre outros."

As teorias, e não os testes experimentais, são o coração da Ciência. É muito simples o motivo pelo qual há mais disciplinas teóricas do que de laboratório, assim como pelo qual as aulas de laboratório começam com exposições teóricas: sem teorias, nenhum experimento faz sentido. Popper esclarece isso quando diz (2013, p. 113): 
"[...] a situação real difere muito da visualizada pelo empirista ingênuo ou pelo adepto da Lógica Indutiva. Acreditam eles que partimos da reunião e acomodação de nossas experiências e que dessa maneira ascendemos na escala da Ciência."

Lembremo-nos que "a teoria domina o trabalho experimental, desde o seu planejamento inicial até os toques finais, no laboratório" (ibid., p. 115).

Em toda a história da Ciência, especialmente após Galileu, tivemos fantásticos exemplos dos mais belos e impactantes experimentos que transformaram para sempre os rumos da Ciência: o prisma de Newton, a medição da velocidade da luz por Fizeau, o pêndulo de Foucault, o experimento do equivalente mecânico do calor de Joule, o bombardeamento da folha de ouro com partículas alfa de Rutherford, a medição do desvio da luz no eclipse de 1919 por Eddington, dentre tantos outros. Ainda assim, nenhum desses experimentos seria sequer cogitável sem as teorias elaboradas previamente que Ihes ditaram a direção. Foram as teorias que disseram o que deveria ser observado, de que maneira a observação deveria ser realizada e, posteriormente, interpretada. O prof. Martins é muito claro em seu artigo de 1993 (p. 8) que trata sobre o debate entre as ideias de vácuo e da existência de éter:

"[...] Não é preciso ir ao laboratório para se determinar se o vácuo existe ou não; nossa razão pode mostrar que o vácuo é impossível. Isso não quer dizer que a observação e a experimentação sejam sempre dispensáveis; mas quer dizer que um empirismo cego é pura perda de tempo, em certas questões fundamentais. Pascal fez muitos experimentos e defendeu a existência do vácuo. Descartes, sem se dedicar a experimentos semelhantes, mas aceitando os experimentos alheios como corretos, negou o vácuo e afirmou o éter. Por sua conclusão e pelo seu método 'científico', Pascal atrai imediatamente a simpatia de um pesquisador moderno, que é tentado a dizer: 'Coitado desse Descartes, só disse bobagens!'. Não vamos negar o valor do trabalho de Pascal; mas vamos procurar mostrar o 'outro lado'. Isso permitirá, esperamos, uma melhor compreensão do papel da razão na ciência."

Completo dizendo: o papel da razão na Ciência é o principal. E o artigo citado é um exemplo disso. Nele, em resumo, o prof. Martins utiliza um argumento simples mas contundente, capaz de demonstrar unicamente pela razão algo que nenhum teste empírico jamais conseguiria: a inexistência do vácuo absoluto (sem entrar nas modernas e complexas questões envolvendo o "vácuo quântico"). E isso pelo mesmo motivo que nenhum teste empírico pode demonstrar a inexistência do éter - 
"inexistência" é uma condição inalcançável pelo teste empírico; mas a razão pode demonstrá-la, se a dita possibilidade de existência se mostrar um absurdo. O argumento utilizado no artigo é, em síntese, o seguinte ${ }^{74}$ : sabemos que há algo no vácuo (p. ex. um raio de luz se propagando por ele). Mas esse algo que há ou é uma substância, ou é uma propriedade de uma substância ${ }^{75}$. Se é uma substância, então não estamos falando de vácuo, pois este é, segundo uma concepção de "espaço vazio", a ausência de substância. Mas se não é uma substância, então é uma propriedade que existe em uma substância, que necessariamente precisa estar no local para que a propriedade também esteja. Mas se ali existe uma substância que possui a propriedade empiricamente detectável, ainda que a substância mesma não o seja, então também não se trata de um vácuo, de um "espaço vazio". Logo, um vácuo é impossível logicamente (eu diria, com licença ao professor, ao qual muito respeito e admiro, que é metafisicamente impossível - como consequência, também será fisicamente impossível ${ }^{76}$ ). A conclusão do prof. Martins (p. 17) é que "o 'espaço

${ }^{74} \mathrm{O}$ artigo lista vários argumentos historicamente formulados por diversos filósofos. Aqui indico apenas o argumento mais sintético. Recomendo a leitura do artigo para maiores esclarecimentos.

${ }^{75}$ Essa é uma dicotomia derivada da Teoria de Substrato (que afirma que existe algo que dá base para as propriedades de tudo o que existe). É uma visão tipicamente aristotélica. Tal dicotomia não existe para quem adota uma Teoria de Pacotes (que afirma que esse tal "algo" não existe, e que tudo o que forma um objeto é o coletivo de suas propriedades). Essa é uma visão humana e essencialmente fenomenológica. Ambas as visões apresentam problemas. $O$ prof. Martins opta em sua argumentação por uma Teoria de Substrato, no qual concordo com ele, mas é preciso deixar claro que a tendência na Física atual é para a abordagem de Pacotes. Para uma discussão mais aprofundada, ver Krause, 2017, cap. 6, seção 4.

${ }^{76} \mathrm{O}$ prof. Martins, em seu artigo, se posiciona claramente contra o positivismo (p. 12). No entanto, ele também, ao que parece à primeira vista, não fala a favor da Metafísica (p. 11), dizendo que "hoje, em dia, seria difícil querer fundamentar a ciência pela metafísica". Não só hoje em dia, mas no passado e também no futuro, a Ciência sempre está fundamentada pela Metafísica. Em realidade, o artigo inteiro é uma grande argumentação metafísica, com implicações físicas autênticas, como toda boa e racionalmente conduzida especulação metafísica deve ser (especulações que divagam sobre planos sobrenaturais, mas sem nenhuma espécie de experiência direta e objetiva, ou que não tenham nenhuma consequência empírica, lógica, epistemológica ou metodológica para nós, mortais, aqui no mundo físico, não deveriam ser classificadas como Metafísica - pode ser Teologia, ou então especulação pura e simples etc.). Creio que a discrepância se dá pelo prof. Martins não estar utilizando a exata mesma definição que eu estou. Ele argumenta em prol da utilidade das entidades não-observáveis (ou seja, não passíveis de teste empírico, i.e., em minha concepção, metafísicos), mas considerando-as, assim mesmo, como sendo assunto da Ciência. Não nego que a Ciência utiliza esses conceitos; mas, da forma como interpreto, é apenas a simples constatação de que é impossível uma Ciência dotada unicamente de enunciados empíricos. Nego, inclusive, a existência desses últimos: não existe um único enunciado puramente empírico - ou eles são puramente metafísicos, ou eles são parcialmente metafísicos parcialmente empíricos. Uma consequência disso, que não tenho espaço aqui para demonstrar (ver apêndice), é que algo fisicamente possível deve 
vazio' dos físicos atuais é muito semelhante ao éter de Fresnel e de Lorentz, mas tem outro nome". Vemos que a razão pode nos levar muito longe. Com o apoio do conhecimento empírico, pode nos levar ainda mais longe, mas ela pode se sustentar por ela mesma, diferentemente do conhecimento empírico, que não tem significado sem o fundamento racional.

O conhecimento obtido através de observações empíricas, os dados da experiência dos sentidos, seja dos sentidos nus, seja dos sentidos equipados por aparatos tecnológicos, só pode ser entendido conceitualmente. Este é um ponto central no qual recorri ao longo desta dissertação (e que terei, inevitavelmente, de recorrer novamente mais adiante). No debate empirismo versus racionalismo, 0 racionalismo venceu, de jure e de facto, apesar de este último fato ser mascarado pela forma como a Ciência é ensinada e divulgada. É evidente que o teste empírico sempre terá um papel crucial nas Ciências. Mas a primazia é e sempre será da teoria. A coleta de dados empíricos existe em estado rudimentar até entre os animais selvagens. Mas o pensamento conceitual, a elaboração de hipóteses que organizam e nos permitem avançar no entendimento do mundo, é exclusivo dos seres racionais - até o momento, apenas o ser humano.

Alguém diria que a pele (ou as escamas, ou qualquer outro tipo de revestimento) é o que caracteriza um animal? É claro que o revestimento é essencial para a sobrevivência, mas seria ele mais importante, ou teria ele primazia, sobre a organização fisiológica interior? Alguém diria que, para o sedento, o copo é mais importante do que a água nele contida? Se a resposta for "não" (espero que seja), por que afirmar que o experimento é o mais importante, o diferencial da Ciência? Uma hipótese pode estar correta antes de ser testada, mas um experimento não possui

necessariamente ser metafisicamente possível. Mas algo metafisicamente impossível (no caso, a existência do vácuo), necessariamente será, também, fisicamente impossível - e é por isso que a razão pura, o nosso principal instrumento para lidar com a Metafísica, pode nos fornecer respostas inequívocas acerca do mundo natural, que seria, de acordo com a visão distorcida dos nossos dias, assunto exclusivo da Ciência e que a Metafísica nada teria a ver com isso. O estudo das entidades em si mesmas (Ontologia), assim como a de suas propriedades (ou acidentes) é o assunto essencial da Metafísica, e só o é da Física (e demais Ciências) por acidente - pelo fato de que algumas dessas propriedades (mas não as substâncias em si mesmas, "as coisas em si" de Kant) estão ao alcance de nossos testes empíricos. Inclusive, um dos argumentos utilizados pelo professor contra o vácuo foi extraído justamente d'Os Primeiros Princípios de Metafísica [!] da Natureza, de Kant. Creio que o prof. Martins, tão ilustrado quanto é, o qual, infelizmente, não conheço pessoalmente, concordaria comigo se pudesse ouvir todo o meu argumento. Espero um dia poder fazê-lo. 
qualquer significado sem uma teoria que Ihe embase. Diz Laudan (1993) (os itálicos são meus):

"A posição que a ciência desfruta em nossa cultura emerge diretamente das teorias científicas e do controle preditivo e manipulador que essas teorias conferem a quem as domina. Saber é poder e, no que diz respeito à ciência, o saber reside nas teorias que os cientistas desenvolveram. E não são apenas os filósofos que consideram as teorias como centrais à compreensão do empreendimento científico. Muitos sociólogos da ciência contemporâneos também consideram a formação de teoria, o teste de teoria e a substituição de teoria como as atividades centrais da ciência."

Todo o saber científico orbita em torno de suas teorias. Isso é exatamente o contrário do que normalmente se ensina nas escolas e nos cursos de graduação, assim como na divulgação científica em geral. Não que teorias não sejam valorizadas ou não sejam ensinadas: pelo contrário, como disse no início desta seção, elas são, na prática, muito mais valorizadas e ensinadas do que os aspectos experimentais. A questão toda está na contradição de, na prática, dar-se maior ênfase no aspecto teórico da Ciência, enquanto se afirma repetidamente que o caráter distintivo da Ciência provém dos testes empíricos. Mesmo sendo necessário embasar teoricamente qualquer experimento simples de laboratório de primeiro semestre de graduação, o que mais se ouve é que são as teorias que são embasadas pelos experimentos!

Um dos livros mais utilizados por estudantes brasileiros de Física é o premiado Curso de Física Básica do respeitável professor Herch Moysés Nussenzveig. Na Introdução do volume 1 (2002, p. 3), o prof. Nussenzveig diz que, no método científico, a observação e a experimentação...

"...são o ponto de partida e ao mesmo tempo o teste crucial na formulação das leis naturais. A física, como ciência natural, parte de dados experimentais. Por outro lado, o bom acordo com a experiência é o juiz supremo da validade de qualquer teoria científica. Assim, o diálogo Hegeliano: 'Só pode haver sete planetas. — Mas isso contradiz os fatos! Tanto pior para os fatos!' representa o oposto da atitude científica. A única autoridade reconhecida como árbitro decisivo da validade de uma teoria é a verificação experimental de suas consequências."

Completa, então, citando Poincaré: 
"Embora a ciência se construa com dados experimentais, da mesma forma que uma casa se constrói com tijolos, uma coleção de dados experimentais ainda não é ciência, da mesma forma que uma coleção de tijolos não é uma casa."

Se o leitor acompanhou minha argumentação até o momento, deve ter percebido duas coisas: (1) a reprodução do conceito equivocado de primazia do teste empírico como "ponto de partida" da ciência e (2) a contradição de se dizer que o teste empírico é o juiz para teorias. Afinal, se o teste empírico é o juiz para teorias, essas últimas devem existir antes do próprio teste! E se preexistem, é porque o ponto de partida são elas mesmas. Por exemplo, no diálogo hegeliano citado acima, quando ele diz que "só podem existir sete planetas", essa é a hipótese, o pressuposto teórico, que guiará a observação, que irá então julgar a sua validade.

Todo estudante e professor de Ciências, mesmo os que ministram aulas de laboratório, priorizam o estudo das teorias, despendendo muito mais tempo nelas do que com testes empíricos. Todos convivem em uma realidade de imersão em teorias. Ainda assim, por constantemente ouvirmos o oposto disso, seja com livros ou seja com professores, terminamos apenas repetindo a mesma tese empiricista, mesmo sendo contrária à nossa vivência real. A contradição é tão aguda que torna difícil evitála em nossa prática e em nosso discurso. O próprio prof. Nussenzveig acabou caindo na armadilha. Ainda na mesma página, ele diz:

"O primeiro passo no estudo de um fenômeno natural consiste em fazer abstração de grande número de fatores considerados inessenciais, concentrando a atenção apenas nos aspectos mais importantes. $O$ julgamento sobre o que é ou não importante já envolve a formulação de modelos e conceitos teóricos, que representam, segundo Einstein, uma 'livre criação da mente humana'."

Aqui o professor afirma que a Ciência começa com a formulação de modelos e conceitos teóricos; afinal, eles são absolutamente necessários para a abstração — o primeiro passo no estudo de um fenômeno natural. E o processo de conceituação, como disse Einstein e como o próprio prof. Nussenzveig concorda, é um processo de "livre criação da mente humana", e não um processo extraído ou emergido de dados empíricos. Sem esses conceitos teóricos, de acordo com a analogia de Poincaré, os dados são inúteis (de fato, são ininteligíveis). 
Por fim, convoco, novamente, as palavras do prof. Martins acerca do debate em questão (1993, p. 24, [ ] meus):

"Há até hoje uma visão ingênua do papel da experimentação na ciência, que ridiculariza o uso de raciocínios a priori. Um exemplo dessa visão é o famoso episódio introduzido por Brecht em sua peça teatral Galileo Galilei, em que os filósofos escolásticos se recusaram a olhar pelo telescópio de Galileo sem antes discutir a possibilidade teórica de ver aquilo que Galileo diz que pode ser visto através do instrumento. 'Recusar-se a olhar pelo telescópio de Galileo' tornou-se uma representação simbólica de um espírito anticientífico e preconceituoso. Suponhamos que alguém, hoje, dissesse: 'Venha, já que você não acredita, eu vou Ihe mostrar um vácuo'. Qual seria a atitude 'científica', nesse caso? Em minha opinião, a melhor atitude é algo muito parecido com a atitude atribuída por Brecht aos filósofos peripatéticos: 'Não vou perder tempo tentando ver algo que não pode ser mostrado'. A razão pode provar que não se pode mostrar um vácuo [conforme argumentação ao longo do artigo em questão]. E isso independe do progresso científico, dos aparelhos porventura inventados etc. A razão não é onipotente; mas o empirismo também não é. Nosso conhecimento científico é uma combinação de elementos vindos da experiência com elementos vindos da razão. Quando um desses instrumentos tenta invadir o campo do outro, nada de bom pode resultar."

Como exemplos de "quando um desses instrumentos tenta invadir o campo do outro", temos um experimento que tenta provar algo que a razão já demonstrou ser impossível (como a própria existência do vácuo absoluto, tema do artigo do prof. Martins), ou a razão fazer uso de uma lógica falsa, autocontraditória, falaciosa, para tentar impor conclusões sobre a realidade (algo comum de se ver em debates ideológicos e políticos).

Imaginem que um ser sobrenatural surja para punir a humanidade. Ele nos impõe um dilema: "O que vocês preferem: que eu apague de todas as memórias e de todos os registros as suas teorias científicas ou os seus dados empíricos coletados em toda a história da sua espécie?". Espero realmente que a decisão caiba a alguém de tendência racionalista! Se escolhêssemos permanecer com nossos dados empíricos, ao custo de perder todas as nossas teorias, ficaríamos sem nada de útil. Nenhuma informação, em nenhuma memória, livro ou computador, faria sentido. Poderíamos entrar em um laboratório, o templo supremo do empiricismo, e simplesmente não saberíamos o que fazer; não teríamos sequer a ideia de para que 
servem os equipamentos que ali estão. Poderíamos passar séculos e mais séculos analisando os dados, sem chegar a conclusão alguma sobre nada. Por outro lado, escolhendo manter nossas teorias, em pouco tempo poderíamos recuperar todas as informações empíricas perdidas. Já saberíamos o que, onde e como procurar pela informação. Iríamos direto ao ponto e a nossa Ciência voltaria ao seu estado atual em um tempo relativamente curto. Espero que, com esse exemplo imaginário, tenha ficado um pouco mais claro o quanto a Ciência é mais dependente da teoria do que do experimento, o que torna no mínimo questionável a caracterização da mesma como sendo essencialmente empírica.

Contudo, a tese empiricista (com raízes no positivismo lógico, naturalmente indutivista) predomina, de maneira injustificável. Voltarei a esse ponto mais adiante, no Capítulo III, quando tratarei do ensino e da divulgação científica.

\subsection{0 - Três tipos de distorções na visão acerca da Ciência}

\subsection{1 - Palavras iniciais}

Os diferentes tipos de distorções acerca de o que é Ciência e de como ela funciona podem ser sintetizados em três. Eles já foram, em parte, delineados nas seções anteriores, mas agora serão analisados em maiores detalhes. São eles: o cientificismo, a anticiência e a pseudociência. Podemos imaginar cada uma dessas três visões como estando em um vértice de um triângulo equilátero, enquanto a Ciência "concreta", "pura" por assim dizer, estaria localizada no centro.

Defendo que uma equilibrada visão da Ciência, tal como ela de fato progrediu e tal como ela é de fato praticada, é a mais bela e rica de todas. É evidente que esse centro, assim como essa "concretude" e "pureza", e também a maneira de determinar como "de fato" a Ciência é, são conceitos difíceis de delimitar, sendo essencialmente interpretações incapazes de angariar um amplo consenso. Apesar dessa dificuldade inescapável, a tarefa precisa ser feita, tão precisamente quanto possível. Isso, pois, essa é a "cara" que a Ciência deveria apresentar como cartão de visitas, através do professor e do divulgador, ao público leigo. Essa visão realista está mais de acordo 
com a plural e complexa natureza humana, ao mesmo tempo em que se porta como uma rigorosa (mas não dogmática) e altamente eficaz ferramenta para a obtenção de meios de melhoria de nosso conhecimento do mundo natural. Vejo como um dever do cientista, do filósofo da Ciência, assim como do professor e do divulgador, defender essa visão contra os três perigos - as três distorções acima citadas.

Ao longo dos próximos parágrafos, falarei por diversas vezes que "divulgadores, cientistas e professores dizem isso ou aquilo", e talvez o leitor sinta falta de exemplos. Três desses exemplos já foram dados: Stephen Hawking, o médico português que cedeu entrevista à Folha e Carl Sagan. Não coloquei mais exemplos aqui pelo simples fato de ter dedicado todo o Capítulo III para esse fim. Nele, trarei muitos e convincentes exemplos que sustentam boa correspondência com o que defendo na presente seção. Além deles, conforme já citado anteriormente, muitos outros casos já foram analisados na literatura acadêmica, como em Cardoso et al. (2015) e Porto e Schmiedecke (2015). Dito isso, começaremos com um estudo sobre o cientificismo.

\subsection{2 - Primeiro modo de distorção: Cientificismo}

Começando pelo cientificismo, é preciso deixar claro que não pretendo criar um rótulo de "cientificista" para ser atribuído a pessoas. O foco maior é em mostrar que ideias e comportamentos podem ser cientificistas, e que, como é evidente, os limites entre a Ciência e o cientificismo não são perfeitamente determinados. Existe um conjunto de ideias, equivocadas em minha visão, que são propagadas como sendo "a verdadeira Ciência", mas que derivam unicamente do desconhecimento (ou da falta de análise crítica) da história e da Filosofia da Ciência. Pesquisas como a de Gil-Pérez et al. (2001) e Lederman (2007) trataram extensamente dessas ideias distorcidas, ideias essas pelas quais muitas pessoas são apresentadas à Ciência. Oliveira (2011) também criticou tais exposições cientificistas, tais como as que ocorrem comumente em obras de ficção científica. O argumento gira em torno de não se "mistificar" a Ciência, atitude essa que tende a nos fazer submissos a ela, como se fosse ídolo de perfeição "que liberta e apraz", ignorando "que ela também aprisiona e oprime" (op. cit., p. 24). Temo que tais exposições distorcidas causem dois principais efeitos perniciosos: criam mais pessoas de tendência cientificista ou criam mais pessoas 
avessas à Ciência. Como procurarei deixar claro, isso ocorre devido à tendência ao extremismo de tais ideias; e ideias extremas induzem pessoas aos extremos, sendo que faço apologia de uma visão não-extremista, uma visão equilibrada.

Um artigo seminal que trata do tema cientificismo é o já citado Six Signs of Scientism, de Susan Haack (2012). Nele, como o título indica, a autora lista seis pontos que caracterizam o cientificismo. Buscando uma síntese, pude resumir os seis pontos em dois grandes aspectos gerais e complementares: o cientificismo age I exaltando a Ciência de forma presunçosa e acrítica, superestimando a extensão e a profundidade de suas capacidades, e II - taxando outros conhecimentos como inferiores ou até mesmo como desprovidos de sentido. Este último aspecto é especialmente pernicioso quando o conhecimento inferiorizado é a Filosofia. Podemos rastrear as origens desse fenômeno no passado, passando pelo Positivismo Lógico do Círculo de Viena, pelo Positivismo de August Comte (ambos, por exemplo, considerando como inferiores a Teologia e a Metafísica - ver Lacerda, 2009, pp. 3301), chegando no lluminismo e, possivelmente, ainda mais para trás na história. Embora explorar essas origens não seja o objetivo do presente trabalho, é importante reconhecer duas coisas: (1) muitos trabalhos de divulgação dos últimos anos seguem essa tendência (conforme darei exemplos notáveis mais adiante, além dos que já apresentei em seções anteriores) ao mesmo tempo em que (2) essa tendência é prejudicial, uma vez que, dentre outros fatores, filósofos frequentemente têm papéis centrais quando o assunto é defender a Ciência contra as investidas das pseudociências e similares (Hansson, 2011).

Procurarei agora expandir a argumentação acerca do cientificismo. Embora esteja longe de ser um debate conclusivo, creio que sua presença é essencial em uma formação científica adequada aos nossos dias. Vou concentrar a argumentação em cinco pontos, que foram os mais recorrentes dentre os encontrados em minha pesquisa:

(a) A ideia de que uma teoria científica é algo que foi "comprovado" e que deriva de "observações". (Uma variante dessa ideia é a de que uma hipótese "comprovada" transforma-se em uma teoria.) Isso é próximo da "visão empírico-indutivista" de GilPérez et al. (2001) e de Praia et al. (2002, p. 479).

(b) A ideia de que uma teoria que "não seja científica" é falsa (aqui há o pressuposto de ser simples e clara a divisão entre teorias "científicas" e "não- 
científicas" — ou mesmo que o título "teoria" deveria ser exclusivamente destinado a "teorias científicas"). Essa ideia está intimamente relacionada à concepção rígida de que há um único, fechado e bem definido "método científico". Isso é próximo da "visão rígida da Ciência" de Gil-Pérez et al. (2001).

(c) A ideia de que a Ciência nega a Filosofia (sobretudo a Metafísica), assim como as religiões particulares e a fé em geral. Isso inclui dizer que a Ciência está livre de concepções metafísicas e de crenças de qualquer tipo.

(d) A ideia de que as teorias científicas são "retratos" ou "representações" do mundo natural, sendo as únicas explicações possíveis ou aceitáveis para os fenômenos observados. É o já citado "realismo ingênuo".

(e) A ideia de que ao menos alguns de nossos resultados científicos atuais são tão certos e definitivos que é absurdo ou "sem sentido" questioná-los.

Começando por (a), muito já foi dito na seção 1.4, mas aproveitarei agora para realizar alguns adendos. Em primeiro lugar, uma teoria, científica ou não, jamais é comprovada. Portanto, aquela velha história de se defender tal ou qual ideia, concepção, política pública, produto, método etc. como sendo "cientificamente comprovado", que tanto vemos nas propagandas e nos debates, carece de sentido.

É preciso lembrar que, para ser uma teoria, é necessário que ela faça afirmações universais, não no sentido de serem válidas "no universo inteiro" embora, às vezes, seja isso mesmo o que se queira dizer - mas no sentido de fazer uso de termos universais. Por exemplo, se eu digo que "corpos caem em linha reta", os termos "corpo", "cair" e "linha reta" fazem referência a todos os corpos, a todas as quedas desses mesmos corpos e à forma da trajetória de todas as quedas desses mesmos corpos, no passado, no presente e no futuro, aqui e em qualquer outro lugar do espaço. Mas é evidente que, para comprovar uma afirmação como essa, seria necessário de facto testar a queda de todos os corpos existentes e verificar que de fato eles caem em linha reta. Isso é absolutamente impossível ${ }^{77}$.

Se temos uma informação empírica - a de que os corpos que já foram vistos

\footnotetext{
77 Isso constitui o Problema da Indução. Já abordei o problema desde o início deste trabalho, e por isso não coloco novas referências a respeito. Mas resulta muito interessante conhecer a origem da argumentação que colocou esse problema como central para a Teoria do Conhecimento. Para tal, a obra-chave a ser estudada é Investigações Sobre o Entendimento Humano de Hume. A própria Lógica de Popper aborda amplamente o tema, assim como Conhecimento Humano de Russell e inúmeros outros. É realmente uma pena que esse ponto continue não sendo bem abordado no ensino e na divulgação de Ciências. Ver referências.
} 
caindo o fizeram em linha reta, e queremos explicar tal fenômeno, obrigatoriamente precisamos de uma explicação de nível superior, que transcenda a experiência e a própria natureza empírica da experiência, extrapolando o que observamos para casos que ainda não foram (e que em sua maioria nunca serão) observados. Esse é um dos pontos mais importantes da argumentação de Popper n'A Lógica e não vejo como objetá-la.

Observar vários corpos diferentes caindo sempre da mesma forma que a teoria diz que eles devem cair corroboram a teoria, mas isso tão somente significa que nosso senso psicológico de convicção em tal teoria (podemos também chamar de "crença racional" na teoria) tende a aumentar com cada "confirmação", mas de forma alguma isso é uma "comprovação". O segundo erro de (a) é afirmar que teorias derivam das observações. Isso também já foi muito abordado no presente trabalho. Tal crença nada mais é do que a (quase) superada doutrina do empirismo baconiano, mas que continua sendo ensinada e divulgada como sendo "o método científico". Creem os empiristas que primeiro alguém observou dez, cem, mil ou mais corpos caindo em linha reta, e daí "induziram" que todos os corpos caem em linha reta. O grave erro que reside aqui já foi demonstrado até a exaustão pelos filósofos da Ciência, especialmente os de tendência racionalista como Popper: não existe observação independente de teorias previamente aceitas, nem se pode obter conclusões universais de enunciados particulares.

Os empiristas em geral creem que é possível fazer observações de forma "pura", não enviesada, sem conexão com teorias, de forma que quaisquer observadores independentes, suficientemente preparados, chegariam exatamente às mesmas conclusões se dispusessem exatamente dos mesmos dados empíricos. Isso é equivalente ao exemplo já citado: seria como se todas as civilizações do passado tivessem chegado nos mesmos desenhos de constelações, uma vez que dispunham das mesmas estrelas no céu 78 , algo que não ocorreu. Mesmo com a literatura contemporânea em Filosofia da Ciência considerando essa visão como sendo inadequada para caracterizar a Ciência e a produção científica, tal visão permanece assim mesmo sendo ensinada e divulgada (Praia et al., 2002).

78 Salvo questões concernentes a em qual hemisfério cada civilização estava - o que influenciaria na disponibilidade de estrelas de cada uma. Mas mesmo civilizações localizadas em latitudes próximas, como os gregos e os chineses, dispondo das mesmas estrelas, produziram diferentes constelações. 
O que torna essa visão errada é o simples fato de que um cientista precisa de uma teoria para se entregar às observações, algo que também já abordei nesse trabalho e é amplamente aceito entre os filósofos da Ciência, desde pelo menos Popper até os mais recentes. O mundo e os fenômenos são de tal forma complexos que é impossível encontrar ordem e tirar qualquer conclusão viável se levarmos tudo em conta ao mesmo tempo, ou se simplesmente começarmos a observar o nosso redor a esmo, na esperança de descobrir algo qualquer (mas sem ter a mínima ideia sobre o que seria esse algo). Pelo contrário: temos ideias preconcebidas, que nos direcionam a prestar atenção em certos aspectos do fenômeno pelo qual nos interessamos, tendendo a ignorar todo o resto. É evidente que isso limita a nossa visão, mas essa desvantagem é necessária, uma vez que é justamente essa limitação que faz o cientista olhar de forma concentrada para a resposta que ele está procurando.

Isso é importante: quando um cientista realiza um experimento ou observação, ele está em busca de uma resposta definida. Mas, para buscar uma resposta definida, ele precisa já ter formulado uma pergunta também definida, o que implica uma teoria, mesmo que seja rudimentar. Já dei muitos exemplos disso em seções anteriores, inclusive citando o exemplo que Popper (2013) usa de que "há água dentro do copo". Já no exemplo acima ilustrado, o cientista já havia formulado a teoria de que "corpos caem em linha reta", uma vez que ele jamais chegaria a essa conclusão partindo de observações sem previamente assumir teorias sobre "o que é um corpo", sobre "o que é cair" e sobre "o que é uma linha reta". Na experiência, não temos "corpos", nem "quedas", nem "linhas", mas apenas sensações, que geram perceptos em nossa mente através dos sentidos. Todos esses conceitos não procedem da experiência, mas são racionalmente, intuitivamente e imaginativamente concebidos (ou, sendo mais cru, são inventados).

Um "corpo caindo em linha reta" era, para Aristóteles, "um corpo movendo-se para o chão, para o fundo, para o seu lugar natural: o centro do Cosmo". Para Newton, "um corpo sendo atraído por uma força em direção ao centro de gravidade terrestre" e, para Einstein, "um corpo respondendo a uma distorção do espaço-tempo ocasionada pela presença da massa da Terra". A mesma observação empírica; três conclusões distintas; três ideias autenticamente teóricas e científicas; e um empirismo refutado. Teorias não derivam de observações; teorias são inventadas para dar 
sentido às observações mesmo antes de serem realizadas. E nunca é demais recordar: não há diferença fundamental entre teoria e hipótese - ambas são, em essência, a mesma coisa. Uma hipótese jamais se torna uma teoria quando é comprovada, e isso por pelo menos dois motivos: (1) toda hipótese já é, sob alguma perspectiva, uma teoria, não fazendo sentido transformar-se naquilo que já é, e (2) uma hipótese (e, portanto, uma teoria) jamais pode ser comprovada.

Dando prosseguimento, o ponto (b) é mais complicado. Isso porque, depois de Popper, os cientistas, divulgadores e professores que o estudaram, mas sem levar em conta as críticas que recebeu, sentem-se inclinados a afirmar que a divisão entre o que é científico e o que não é científico é muito bem delimitada. Não é. Popper, com seu critério de demarcação, propôs uma divisão dicotômica: "isto é Ciência", "isto é Metafísica". Para fazer isso, ele parece não ter levado em conta um fato que ele mesmo afirma e torna a afirmar em suas obras, mais ou menos explicitamente: não existe teoria científica que não se apoie em algum princípio metafísico. Ele expressa isso quando faz referência ao conteúdo empírico de uma teoria: algumas teorias são mais passíveis de teste falseador do que outras; as primeiras possuem um conteúdo empírico maior do que as últimas. Não é difícil depreender da sua explicação que o conteúdo empírico de uma teoria é inversamente proporcional ao "conteúdo metafísico" da mesma.

A conclusão que ele sugere, no entanto, é simplesmente classificar como científica (empírica) qualquer teoria que tenha um mínimo conteúdo empírico, conferindo o mesmo status epistemológico a qualquer teoria que seja falseável de alguma maneira: elas são científicas, enquanto que as teorias não falseáveis em absoluto serão metafísicas (ou pertencentes a um outro campo qualquer, que não a Ciência Empírica). Acontece que mesmo uma teoria de altíssimo conteúdo empírico como, por exemplo, a Terceira Lei de Newton, está fundamentada em conceitos metafísicos não falseáveis, tais como o espaço e o tempo absolutos ${ }^{79}$, a massa, o conceito de interação entre corpos e a própria concepção de corpo. Toda teoria possui um "comprometimento ontológico", usando as palavras de Quine. Portanto, toda teoria

${ }^{79}$ No primeiro volume de seu Curso de Física Básica (2002, p. 21), o prof. Moysés Nussenzveig evita elegantemente o termo "metafísica" quando se refere ao tempo absoluto de Newton, chamando-o, ao invés, de hipótese "não-física"! Parece que o termo "metafísica" não pode figurar em um livro de Física (apesar de a Metafísica estar lá de fato e por toda parte), a não ser, talvez, para ser depreciada como "inútil" ou "sem sentido". 
possui um comprometimento metafísico.

Isso quer dizer que não é possível falsear completamente uma teoria, mas apenas alguns de seus enunciados - aqueles que sejam passíveis de teste empírico. Podemos falsear que as forças aparecem sempre aos pares, possuindo o mesmo módulo e sentidos opostos, sendo aplicadas em corpos diferentes e sem nunca se equilibrar; mas jamais poderemos falsear as nossas concepções de força, de massa etc., que são ou definições elementares, ou termos sem definição, ou ainda axiomas metafísicos que são indispensáveis à construção teórica. É claro que, para os engenheiros, pragmáticos por natureza, e para boa parte dos cientistas, é de pouca importância investigar a pergunta: "o que é, de fato, a massa?". Essa questão é puramente metafísica, sem possibilidade (até o momento, pelo menos) de ser testada empiricamente, o que fez Comte condenar e considerar inútil a busca por uma resposta a ela.

O que essa concepção positivista ignora é ser sumamente impossível utilizar um conceito como "massa" sem possuir uma concepção, ainda que implícita, do mesmo. Não é por que o Físico abandonou o questionamento acerca "do que é massa" que ele não está, consciente ou inconscientemente, comprometido com uma ontologia, com uma metafísica, da massa.

Tal concepção ontológica transcende qualquer observação, experimentação ou empirismo. Ela tem de ser uma concepção metafísica. Em outras palavras, não é possível "se livrar" da Metafísica. Ela sempre estará lá. Se a vemos, concordamos ou aceitamo-la, é outra questão. O que se pode concluir é que não há uma divisão dicotômica entre o que pertence ao campo da Ciência empírica e o que é Metafísica: toda teoria faz mais ou menos uso de proposições empíricas e de proposições metafísicas, transformando, como proponho, a dicotomia em um continuum. Assim, é possível uma teoria que seja 50\% empírica e 50\% metafísica, que seja 5\% empírica e $95 \%$ metafísica ${ }^{80}$, ou quase qualquer outra combinação dos dois ingredientes. Digo

${ }^{80}$ A Teoria da Evolução encaixava-se em uma proporção como essa na época de Popper, o que foi um dos motivos que o levou a afirmar que se tratava não de uma "teoria científica", mas de um "programa metafísico de pesquisa". Mais tarde, ele voltou atrás e afirmou que se tratava, sim, de uma teoria científica. Se, ao invés de sua divisão dicotômica, ele tivesse considerado uma distribuição contínua de teorias, provavelmente não teria cometido esse "erro", mas teria apenas considerado a Evolução como uma "teoria científica com baixo conteúdo empírico", dependendo grandemente de asserções metafísicas - em especial, a da Seleção Natural. 
"quase" por haver aqui uma assimetria: é possível uma teoria puramente metafísica ( $0 \%$ empírica), por exemplo, "o espaço é absoluto"; mas é completamente impossível uma teoria puramente empírica (que tenha aniquilado completamente qualquer vestígio metafísico).

Indo agora ao ponto (b) (de que existe apenas um método científico, e o que não é científico é falso), há três conceitos cruciais que nunca podem ser esquecidos pelos divulgadores e pelos professores de Ciências.

Como já explicado na seção 1.4, (1) uma teoria científica é necessariamente incerta, e muitas ideias consideradas não científicas são necessariamente certas em mais alto grau ("choverá ou não choverá aqui amanhã"), (2) o Critério de Demarcação de Popper falha em delimitar precisamente uma teoria em científica ou metafísica simplesmente porque assume uma falsa dicotomia - defendo aqui a tese de que o que existe de facto é um continuum em que empirismo e metafísica complementamse formando o todo que denominamos "teoria científica" - e (3) não existe "o método científico". Sobre esse último ponto, Haack (2012, p. 13) diz que ainda estamos à espera de uma concordância acerca do que é esse método, sendo que o número de candidatos é enorme: temos diferentes tipos de indutivismos, de dedutivismos, além de outras abordagens mais complexas e até a proposição de que o melhor seria não haver método (Contra o Método, 1970, de Feyerabend é a obra clássica que trata desse aspecto).

Isso já adianta a argumentação referente ao ponto (c) (a ideia de que a Ciência nega a filosofia, ou as religiões, ou a fé em geral). Muito já foi dito em seções anteriores sobre a relação existente entre Ciência, Filosofia, Metafísica, fé e Religião. Em resumo: a Ciência (1) depende absolutamente da Filosofia, tendo dela sido derivada e permanecido como filha que se nutre de sua mãe-raiz, (2) possui ideias metafísicas em seus axiomas fundamentais, sendo impossível libertar-se deles, (3) só pode fazer previsões e ser realmente útil como ferramenta de descrição da natureza enquanto depende da fé que depositamos nesses mesmos axiomas e (4) não deveria ser utilizada para negar ou afirmar qualquer posição religiosa que seja. Sobre esse último ponto, claro está que um indivíduo pode usar sua convicção na Ciência para negar ou afirmar alguma posição religiosa, mas se assim o faz, o faz como posição individual — ele não pode atribuir essa posição à comunidade científica, com essa última sendo formada por indivíduos que adotam as mais variadas posições teológicas e religiosas. 
Nenhum cientista, nem o mais renomado, tem o direito de apelar à autoridade científica para negar ou afirmar, em nome da Ciência, uma posição teológica. Novamente, se ele o faz, o faz por si. Retornarei a esse ponto, com mais referências, em seções posteriores.

Adentrando o ponto (d) (sobre teorias científicas serem "retratos" ou "representações" do mundo natural), temos o clássico debate do realismo científico, central para a Filosofia da Ciência. Esse é um debate extenso, profundo, no qual não poderei ir além de primeiras considerações no presente trabalho.

Considerar uma teoria como retrato do que é a realidade seria o realismo ingênuo. $O$ extremo oposto a isso seria considerar que uma teoria não passa de uma construção puramente da mente humana, sem relação de "verdade" com o mundo exterior, e que, por isso, deveria ser vista no máximo como uma ferramenta útil. $\mathrm{O}$ mais equilibrado, e talvez mais indicado para fins pedagógicos, seria uma posição intermediária: nossas teorias bem fundamentadas possuem algo de real, embora seja difícil dizer o que é exatamente e qual a profundidade desse real. Como a atitude cientificista é caracterizada por uma aproximação, para não dizer completo compromisso, com o realismo ingênuo, será contra ele a minha seguinte argumentação.

O caso sobre a gravidade, acima citado, parece um bom exemplo a ser utilizado. A concepção aristotélica foi, por alguns e por algum tempo, considerada como um "retrato" da realidade. Muitos se decepcionaram ao perceber que o "retrato" não era nada mais do que uma concepção inventada por um homem que buscou uma explicação para o mistério do mundo. Newton mostrou que Aristóteles estava "errado", e agora oferecia o verdadeiro "retrato": massa atrai massa com uma força de longa distância que se propaga instantaneamente pelo espaço e pelo tempo absolutos! Muitos creram ser esse o verdadeiro "retrato", apesar de ninguém poder dizer nada de satisfatório ou que não fosse meramente arbitrário acerca do que, realmente, em essência, seriam "massas", "forças", "espaço e tempo absolutos" etc. Mas o que a história da Ciência parece nos dizer é que os cientistas acolheram a explicação de Newton de fato como um retrato; e é indubitável que muitos se chocaram quando Einstein propôs suas radicais ideias relativísticas, rejeitando a gravidade newtoniana em seus pontos mais fundamentais. Agora sim! Temos o nosso "retrato" da natureza! A massa (que ainda não sabemos o que é — ou talvez saibamos através de um dos 
mais recentes "retratos" obtidos pela Ciência: é uma "interação" mediada pelos "bósons de Higgs" entre as partículas que formam o corpo e o "Campo de Higgs"!) distorce o espaço e o tempo, que agora são relativos e, em síntese, uma coisa só, o espaço-tempo quadridimensional; e os demais corpos, mesmo os não dotados de massa (como os fótons), não sofrem força alguma, mas apenas "respondem" à tal distorção! É claro que agora, finalmente, depois de ao menos essas duas mudanças radicais, chegamos no nosso "retrato" da natureza, correto? Não mesmo! Não há, absolutamente, nenhum motivo para crermos nisso. E isso é válido para qualquer teoria. Se uma teoria fosse o retrato da natureza, ela seria definitiva: explicaria todos os fenômenos que propõe explicar, tirando qualquer possibilidade de ser negada, pois já estaria "comprovada" pelo seu perfeito ajuste à realidade natural. Cada geração acreditou possuir o "retrato" da natureza e, por algum motivo, foram contrariados. Por que apenas a nossa geração seria a privilegiada herdeira das teorias que representam a natureza tal como ela é? E por que seriam essas explicações dadas pela Ciência as únicas possíveis ou aceitáveis para os fenômenos observados? Definitivamente não é o caso, e a Ciência precisa ser ensinada e divulgada de outra maneira.

Por outro lado, é bem razoável aquela visão de realismo científico moderado que assume que algo de verdade deve estar contido em cada uma dessas teorias. $O$ argumento em defesa do realismo de Putnam (1975), conhecido como "Argumento do Milagre", embora contestado por antirrealistas, permanece muito poderoso e as tentativas de refutação que recebeu (como a de van Fraassen, citada logo adiante) não parecem suficientes para aniquilar a ideia completamente. Em resumo, Putnam afirma que seria um milagre que nossas teorias fossem tão bem-sucedidas, especialmente em suas previsões, caso não tivessem alguma correspondência com a realidade do mundo físico. Negar completamente que possa haver tal correspondência é cair no puro pragmatismo teórico, considerando teorias como meras ferramentas, e colocando a humanidade em um estado de eterna escuridão acerca do que crê saber acerca do mundo natural. Essa visão é chamada de instrumentalismo e foi defendida por Pierre Duhem (1954), além de ser muito próxima da visão de Ciência como resolução de problemas de Larry Laudan.

Como já adiantei anteriormente, não creio que essa posição extremada seja adequada para fins pedagógicos, embora o seu debate na academia seja extremamente relevante. Negar que a Ciência progrediu e nos permitiu (e ainda 
permite, diariamente) fazer previsões acertadas é absurdo. Daí para se aceitar que há algo de real nas teorias é um passo simples e, considero eu, necessário para um ensino equilibrado de Ciência.

Deve haver algo que se preserva, que se sustenta de modelo em modelo, e que mostra que as explicações científicas são mais do que ferramentas úteis. Essa posição é defendida por Psillos (1999, p. 108, tradução livre): "é suficiente mostrar que leis e mecanismos teoréticos que geraram os sucessos das teorias do passado foram retidos em nossa atual imagem científica". Nesse caso da gravitação, parece que o que há de comum às três concepções de gravitação é o fato de que grandes massas planetárias são as responsáveis por dar origem ao movimento de atração de corpos próximos a elas. As palavras aqui são escorregadias: usei termos como "massa", "movimento", "atração" e "corpos" com um certo sentido, mas o sentido que esses termos assumem em cada teoria varia. Se ficarmos presos à literalidade das palavras, ficará evidente que as teorias são incompatíveis e que não existe esse "fio condutor" que sobrevive de uma a outra (a chamada incomensurabilidade de Kuhn, a qual abordarei no Capítulo II). Mas é sensato dizer que há apenas um fenômeno acontecendo, independente da mente do observador (que é um dos pressupostos do realismo), e se uma teoria o chama de "queda de corpo" ou de "atração gravitacional" é uma mera questão de roupagem; o essencial permanece, ainda que não a sua interpretação. A interpretação (já impregnada de teoria) desse "essencial" é o que nós chamamos de "fatos"; a essência mesma do fenômeno, a qual um realista moderado assume existir, é inacessível a nós, uma vez que ao utilizarmos termos para descrevêla já estaremos interpretando-a dentro de concepções teóricas.

É preciso parar de se ensinar e divulgar teorias científicas como "fatos". Afinal, por que ocorreram mudanças tão agudas na Ciência, se os cientistas lidam com "fatos" desde sempre? É verdade que os microscópios e os telescópios permitiram apenas recentemente o acesso a determinados dados empíricos. Mas a queda de um corpo esteve acessível desde sempre! Como é possível que três homens, definitivamente esclarecidos e inteligentes, pudessem ter oferecido explicações tão diversas para o mesmo fenômeno? E é digno de nota que esse seja um fenômeno que poderia facilmente ser classificado como um dos mais simples existentes. É claro que tal simplicidade é apenas aparente. Ele não é realmente simples. Tanto não é que as explicações para ele aumentaram de maneira estonteante em complexidade: foram 
saltos magistrais de Aristóteles para Newton e, depois, de Newton para Einstein, cuja descrição ainda é incompleta.

Isso nos conduz à resposta da seguinte pergunta, pergunta essa que deveria ser feita com mais frequência: "Por que criamos teorias?". Bachelard, em A Formação do Espírito Científico (2007), afirmou que todo conhecimento (que aqui interpreto como a criação de uma teoria) é a resposta para uma questão. Em uma frase: criamos teorias para suprir lacunas de informação empírica não explicadas por teorias anteriores. Quanto maior a lacuna, mais transcendente com relação aos dados experimentais uma nova teoria precisará ser. Isso implica dizer que a teoria terá um menor conteúdo empírico, sendo, portanto, relativamente mais metafísica, e estando mais sujeita a ser considerada como equivocada quando novos dados empíricos vierem à tona. Para ilustrar, vejamos novamente o caso da invenção da Teoria da Periodicidade dos Elementos, tradicionalmente creditada a Mendeleiev no século XIX.

Por aquela época, conheciam-se cerca de 60 elementos, com várias de suas propriedades já determinadas. A mais importante era, em muitos contextos, o peso atômico. Químicos anteriores a Mendeleiev já haviam tentado uma organização periódica por ordem de pesos atômicos. O químico russo, porém, precisou, em certos casos, prescindir desse critério de organização, com o propósito de agrupar elementos de maior semelhança na mesma família. Esse foi um salto que podemos considerar ousado, pois abdicava de uma das mais sólidas fontes empíricas disponíveis de informação acerca dos elementos. Esse salto poderia facilmente estar errado mas, ao final, foi corroborado - verificou-se que Mendeleiev adiantou o critério de classificação que leva em conta algo desconhecido à sua época: o número atômico. Enfim, feita a organização, sobraram lacunas. Para preencher tais lacunas, Mendeleiev desenvolveu a teoria (ou hipótese, tanto faz) de que deveriam existir os elementos que se posicionariam nelas. Ele até mesmo utilizou a sua teoria para prever as propriedades de tais elementos. E ele estava certo: os elementos gálio e germânio foram assim descobertos. Esse caso chama a atenção por uma série de motivos que ilustram a natureza do empreendimento científico. Vejamos alguns deles.

Podemos começar nos perguntando o motivo de uma classificação periódica (ou qualquer outro tipo de classificação), que resultasse em previsões tão certeiras, não terem surgido séculos antes e tido o sucesso que teve a classificação de Mendeleiev. Imaginemos como seria classificar os elementos se apenas 30 deles 
fossem conhecidos. Seria muito mais difícil ver sentido e ordem neles, talvez com vários deles parecendo ser demasiadamente estranhos a todos os outros para serem colocados na mesma "família". Por exemplo, suponhamos que apenas um dos elementos que hoje denominamos de "gases nobres" estivesse entre os $30^{81}$. Devido ao excesso de lacunas e às suas propriedades muito peculiares, seria muito mais difícil para um químico analisá-lo e classificá-lo, por não ter outros elementos similares com os quais compará-lo. Vários químicos poderiam criar diversas hipóteses/teorias a fim de dar sentido aos dados empíricos dos 30 elementos, mas devido à escassez desses dados, essas teorias teriam que fazer saltos mais longínquos, mais ousados. Ao longo de toda a história da Ciência, vários saltos como esse foram dados: a Teoria da Evolução, o Big Bang, a Teoria da Relatividade, a Teoria Quântica, apenas para citar as mais impactantes, todas arrojadas por terem ido muito além do que os dados empíricos disponíveis permitiam afirmar com certa segurança. Tanto iam além que até nos dias de hoje são revelados mais e mais dados empíricos, muitos deles inusitados, que continuam acumulando corroborações a tais teorias.

Somos agora tentados a pensar que tais teorias foram propostas por serem as únicas explicações possíveis para os fenômenos que elas, efetivamente, se propõem a explicar. A história da Ciência, sob determinada interpretação, nega tal asserção. Essas teorias foram apenas as restantes na luta pela sobrevivência, ao estilo darwinista, dentre todas as formuladas pelos cientistas de cada época, cada qual buscando "a figura real e total" que as poucas peças de quebra-cabeças de que dispomos parecem indicar (essa analogia de teorias é defendida, por exemplo, por van Fraassen [1980], como uma contestação do realismo - uma teoria é aceita não por ter correspondência com a "verdade", mas simplesmente por vencer suas concorrentes).

Um químico dispondo da informação de 60 elementos tem muito mais base para propor uma teoria de classificação do que um químico dispondo de 30 . $\mathrm{O}$ exemplo é de interesse porque a tabela periódica atual realmente se parece com um quebra-cabeças de 118 peças. Se tivéssemos apenas 30 peças à nossa disposição, mas sem saber qual é a figura da qual elas são parte, estaríamos muito mais sujeitos

${ }^{81} \mathrm{Na}$ época de Mendeleiev, nenhum gás nobre era conhecido. O primeiro descoberto foi o Argônio, em 1894. Embora o Hélio já tivesse sido identificado na cromosfera solar em 1868, foi isolado e quimicamente analisado apenas em 1895. Três anos depois, em 1898, o terceiro gás nobre foi identificado - o Neônio. 
a errar em nossas tentativas de posicioná-las corretamente e também em nossas tentativas de prever essa mesma figura total. Não teríamos nem mesmo como saber com boa precisão quantas peças faltam (isso supondo que o número de elementos seja realmente finito, embora nenhuma lei pareça proibir que haja um número ilimitado deles, levando em conta a possibilidade de continuarmos sintetizando novos elementos).

Isso tudo nos leva a uma reflexão. A elaboração de uma teoria se assemelha muito mais a uma criação artística de que a uma dedução matemática ${ }^{82}$. Tal comparação exibe limitações, é claro, mas tem um valor didático importante. Enquanto esta última, a dedução matemática, parte de axiomas e deduz logicamente as suas consequências, a primeira é um ato criativo nascido de uma necessidade interna do indivíduo. É comum ouvir de artistas que criam porque têm necessidade de criar, porque sentem um impulso de se expressar, seja por meio de formas, movimentos, sons ou cores. De onde vem esse impulso e qual a sua natureza é assunto da psicologia, e não terei como desenvolver esse ponto agora, mas o que interessa é que ele existe ${ }^{83}$. Uma teoria científica não é deduzida de uma fonte de informação antecedente, embora necessite de axiomas prévios para ter algum valor (em realidade, a criação de uma teoria científica é, numa aproximação não muito rigorosa, a própria invenção desses mesmos axiomas - ou, como são mais comumente chamados, postulados). Teorias são criadas. Elas não derivam de observações, mas ainda que derivassem, essas últimas são representadas por enunciados singulares (exemplo: "Choveu hoje à noite no lugar $\mathrm{X}$, enquanto a temperatura era $\mathrm{Y}$ e a pressão atmosférica era Z") e não por axiomas. Um cientista inventa uma teoria para explicar o mistério permanente que é o mundo, o Cosmo, o Universo. Tal como o filósofo, ele quer respostas, ele anseia por elas, ele devota a sua vida em sua busca e investigação. Para conceber tal resposta, ele não utiliza apenas a razão, mas precisa de todos os demais recursos de que tem disposição: suas concepções prévias, os frutos que obteve da interação com outros estudiosos, sua imaginação, sua intuição, sua criatividade e, por fim, a razão. Sem todo esse aparato, seria impossível os saltos de entendimento que precisam realizar para completar teoricamente as lacunas de

\footnotetext{
${ }^{82}$ A Ciência vista como empreendimento criativo é um dos pontos característicos da Natureza da Ciência de acordo com a lista de Lederman et al. (2002).

${ }^{83}$ Acrescento aqui a minha própria experiência como compositor musical para afirmar que de fato assim é.
} 
informação empírica.

Talvez, se dispuséssemos de absolutamente todos os dados empíricos de que necessitamos, a criação de teorias fosse desnecessária, ou fosse tão somente a escolha de critérios de classificação. Por exemplo, dispondo de todos os 118 elementos de nossa tabela periódica, assim como todos os dados empíricos referente a eles, bastaria escolher um critério de classificação para ordená-los em um todo orgânico que fosse útil e fizesse sentido. Mas aí ressurge aquele tão discutido ponto incontornável: os dados empíricos coletados dependem todos de teorias prévias. Precisamos definir conceitos fundamentais, como densidade, ponto de fusão e de ebulição, potencial de ionização etc. antes de iniciarmos qualquer coleta - do contrário, sequer saberemos o que coletar. A primazia, como é necessário mais uma vez enfatizar, é sempre da teoria sobre o experimento - o oposto do que diz a doutrina empirista.

Voltando à semelhança entre a criação de uma teoria e a criação artística, embora sejam ambas nascidas da potência do indivíduo criador - o cientista ou o artista -, é verdade também que ambas são filhas de seu tempo: o indivíduo está imerso em um espírito característico de sua época e de seu povo, que influencia decisivamente as perguntas que mais the interessam e, por conseguinte, as respostas que mais anseia. E é isso que torna a Ciência parte fundamental da cultura humana, exatamente da mesma maneira que as Artes, a Filosofia e a Religião, algo defendido há décadas pelo respeitável professor João Zanetic (ver nas referências, por exemplo, seus trabalhos de 1991, 1997 e 2006).

Essa característica profundamente, marcadamente, indissociavelmente humana da Ciência exige mais cuidado por parte dos divulgadores e dos professores. O tratamento comum é o de que a Ciência é um "mundo à parte do mundo", que os cientistas são pessoas muito diferentes das demais, que o método científico nada tem a ver com Arte, Filosofia ou fé, pois só a Ciência lida com "fatos concretos", com "teorias comprovadas pelas experiências e pelas observações" etc. Em grande medida, essa é a "visão elitista de ciência", tal como abordado por Gil-Pérez et al. (2001). O cientificismo é justamente o conjunto de pensamentos aliados a essa última concepção distorcida de Ciência. Ele torna a Ciência algo exótico, pseudoesotérico, estranho, estéril.

Divulgadores afirmam que a Ciência, diferente da fé, "tem a humildade de 
reconhecer que não tem respostas"84, quando, ao mesmo tempo, chegam em suas palestras ou em gravações de documentários para "ensinar" o público sobre "como o Universo surgiu" ou como "a vida teve origem e evoluiu até os dias de hoje", ou sobre "saltos quânticos" e "distorções no espaço-tempo nas proximidades de buracos negros e buracos de minhoca". Dessa forma, ao público, a impressão mais forte é a de que a Ciência possui mais certezas do que dúvidas acerca da realidade, sugerindo que seus conhecimentos são certos e definitivos, invertendo completamente o estado das coisas. Nas palavras de Bagdonas, Zanetic e Gurgel (2014, introdução):

"Se o conhecimento presente em sala de aula é colocado como verdadeiro, independentemente das questões levantadas ou dos contextos situacionais, o exercício de um pensamento crítico por meio de problematizações, debates e reflexões não tem espaço."

Isso responde ao ponto (e): nenhum resultado que a ciência obteve até o momento, deveria ser considerado definitivo.

A maioria dos cientistas poderia considerar absurda a procura por uma máquina de movimento perpétuo, de uma partícula mais veloz do que a luz, de uma medida com precisão maior do que a permitida pelo Princípio da Incerteza de Heisenberg etc. Existem certos resultados que são de ordem metafísica e que realmente são impossíveis: nunca encontraremos um círculo quadrado, nem um ser que seja outro que não ele mesmo. Mas os resultados que impõem limitações físicas não possuem esse tipo de restrição fundamental: embora alguns considerem como limitações da natureza, são mais provavelmente limitações de nossa capacidade de compreender a Natureza. Se afirmamos que é a Natureza que impõe um limite de precisão ou um limite para velocidades, estamos dizendo, literalmente, que de fato desvendamos esse mistério da natureza, que chegamos a retratos finais da realidade. Isso é arrogante e presunçoso; portas para novas ideias e novas abordagens para antigos problemas são fechadas, a imagem da Ciência que transmitimos ao público torna-se irreal e, por fim, caímos no grave perigo da ilusão do conhecimento. Pensamos que sabemos, que atingimos aspectos da realidade última, quando atingimos, no máximo, o fundo de nossas capacidades cognitivas.

Esse tipo de visão acaba tomando uma forma extremada, e como geralmente ocorre em outras áreas, ações extremas geram reações extremas. No caso, o

${ }^{84}$ Um exemplo concreto foi analisado no Capítulo III. 
cientificismo deu origem ao seu polo oposto: os movimentos anticiência. Abordo agora esse segundo tipo de distorção ${ }^{85}$.

\subsection{3 - Segundo modo de distorção: Anticiência ${ }^{86}$}

Dentre as reações anticientíficas da atualidade podem ser citados os movimentos antivacina, o movimento da Terra Plana, os Criacionistas que negam que tenha ocorrido a evolução das espécies ou que negam a antiguidade do planeta Terra, e os que negam o aquecimento global. Há outros, inclusive surgidos recentemente com a crise da COVID-19, mas esses citados permanecem sendo os que mais angariam seguidores ${ }^{87}$. Esses movimentos são formados por pessoas descontentes com a intransigência cientificista (Gil-Pérez et al. [2001, p. 131] chega mesmo a falar em um discurso científico "dogmático"), geralmente tendo como aliados os fundamentalismos religiosos, que, a partir da interpretação literal de suas escrituras, acabam vendo nos "fatos científicos" a negação de sua fé (no caso, a fé prevalecente é a Cristã). Essa questão da interpretação literal é agravada quando os próprios cientistas ou divulgadores de viés cientificista ridicularizam as afirmações das escrituras, tachando de ignorante quem escreveu e quem acredita nelas.

Seguindo uma sequência interminável de ataques, deboches e até mesmo trâmites em tribunais (como os conhecidos casos envolvendo o ensino do Criacionismo nas escolas dos EUA), o resultado é um cenário que não é bom para ninguém: a Religião, que deveria tratar da dimensão espiritual da psicologia humana, acaba com o rótulo de obscurantismo e de atraso, ao mesmo tempo em que certos grupos mais radicais crescem em número e em fanatismo; a Ciência, que deveria tratar do nosso entendimento do mundo natural, se converte em instrumento de propagação da doutrina materialista e do ateísmo, sendo exaltada e superestimada pela visão cientificista, ao mesmo tempo que desprestigiada e desacreditada pelos

\footnotetext{
${ }^{85}$ Existe ainda mais uma característica importante do cientificismo, a saber: a de que a Ciência pode resolver problemas para além de seus domínios, trazendo para dentro de seu escopo, por exemplo, questões éticas. Considerei melhor explorar esse tópico em partes subsequentes.

${ }^{86}$ Em inglês, o termo equivalente parece ser "Science Denialism".

${ }^{87} \mathrm{Faz}$ alguns poucos anos desde a primeira vez em que ouvi falar sobre um movimento que defendia a ideia de que a Terra é plana. Se não me falha a memória, à época (por volta de 2016) a página oficial do movimento no Facebook possuía cerca de 10.000 seguidores. Atualmente (março/2020), a mesma página está para vencer a marca de 110.000 seguidores.
} 
leigos que subestimam os métodos e os resultados científicos. Não vejo como um cenário desses possa ser benéfico para qualquer um dos lados e para a sociedade em geral. Deveríamos estar dedicados a impedir essa escalada de extremismo.

Com relação à Religião, não é nosso papel, seja como educadores, cientistas ou filósofos, trabalhar para alterar dogmas de movimentos fundamentalistas específicos. Mas podemos, sim, demonstrar que o nosso conhecimento científico é incompatível com o religioso apenas enquanto este último é levado a uma interpretação literal. A Ciência não existe para combater a Religião. E a Religião não pode, nem deveria querer, negar dados científicos com base em dogmas. $O$ jogo da Ciência é jogado com as regras da Ciência. As regras da Religião são outras ${ }^{88}$. Uma pessoa pode escolher seguir um ou outro, ou talvez ambos os conjuntos de regras, como muitos cientistas escolhem seguir quando não abandonam sua religião. Diz o prof. Roberto de Andrade Martins (2001, p. 120):

"Algumas vezes, a ciência e a religião estiveram simplesmente isoladas, cada uma cuidando de seus interesses - como ocorreu na maior parte das vezes em áreas como a matemática. Outras vezes houve conflitos. Outras vezes houve integração entre ambos, e é inegável que muitos cientistas procuraram ancorar seu trabalho em fundamentos teológicos."

Os problemas começam a surgir quando se tenta aplicar um conjunto de regras aos assuntos próprios do outro território. E a maneira como isso foi feito ao longo do tempo, é algo que necessita de uma análise para cada caso. Comentarei sobre eles mais à frente. Antes, é preciso um comentário sobre um terceiro modo de distorção científica: a pseudociência.

\subsection{4 - Terceiro modo de distorção: Pseudociência}

É difícil definir a pseudociência com precisão, mas há um certo consenso de que se trata de todo conhecimento que é propagado como Ciência, mas que não segue os métodos tipicamente científicos (Hansson, 1996). Não refiro-me ao tradicional passo a passo, que normalmente é apresentado como o "Método Científico" - visão essa que deveria ser definitivamente abandonada, apesar de ainda

${ }^{88}$ Novamente, indico a dissertação de mestrado do prof. Bagdonas (Henrique, 2011), que trata com maior profundidade a relação entre Ciência e Religião. Aqui, faço apenas um breve comentário, para logo em seguida partir para o meu verdadeiro alvo. 
muito presente (Praia et al., 2002). Refiro-me ao conjunto de práticas dos quais os cientistas efetivamente fazem uso: coleta de dados empíricos, apresentação de resultados parciais em congressos, publicação de artigos com revisão de pares etc. Com todas as falhas e críticas que tais ações típicas do meio científico possam receber, são elas que temos ao nosso dispor. Uma roupagem científica, mas sem as citadas práticas comumente adotadas por cientistas, pode ser vista na astrologia, na ufologia, entre outros. Mais recentemente, vimos o surgir dos coachs quânticos. Comentarei especificamente sobre algumas dessas pseudociências mais à frente.

Não é correto classificar algo como pseudocientífico por "violar o Critério de Falseabilidade", como já ouvi ser dito em certos canais de comunicação. O filósofo Massimo Pigliucci, em um artigo ${ }^{89}$ defendendo o Critério de Falseabilidade contra as críticas de Laudan, diz que (op. cit., introdução, tradução livre) "Popper invocou a falseabilidade como critério que separa a Ciência da pseudociência". Esse argumento não procede. Pseudociência, da forma como a entendemos hoje, é um conceito que sequer existia na época de Popper e o termo não é citado nem uma única vez n' $A$ Lógica. O Critério serve para separar Ciência de Metafísica, o que é radicalmente diferente, a menos que uma tendência positivista induza um crítico a identificar a Metafísica com uma pseudociência, o que nada mais é do que ignorância filosófica. Popper cita, sim, casos como o dos cartomantes, mas não os chama de pseudocientistas, apenas critica o fato de ser uma prática difícil de se falsear. Ainda assim, uma previsão de cartomante pode ser falseável. A astrologia e muitas outras pseudociências também podem ser falseáveis ${ }^{90}$ : elas efetivamente podem fazer previsões testáveis. Não é isso que as tornam pseudociências. Mais amplamente, o Critério de Falseabilidade apenas estabelece uma dicotomia entre o que faz parte da Ciência Empírica e o que não faz, mas sem especificar, para além da Metafísica, o que entraria nesse conjunto de não-Ciência. Se chamarmos tudo o que não é falseável de pseudociência, então estaremos chamando a Religião, a Arte, a História, a Filosofia, especialmente a Metafísica, de pseudociências, ao mesmo tempo em que

89 PIGLIUCCI, M. The Demarcation Problem: a (belated) response to Laudan in Philosophy of Pseudo Science. University of Chicago Press, 2013.

90 A astrologia, por exemplo, foi já repetidamente testada por métodos empíricos (ver, por exemplo, Carlson [1985]). Ou seja, ela é perfeitamente falseável, o que a coloca dentro do campo da Ciência Empírica, de acordo com o Critério de Popper. Para as pseudociências que tratam de métodos de cura alternativos aos da medicina oficial, basta uma afirmação de que o método seja superior ao resultado de placebo, e em seguida submeter os pacientes a testes controlados e verificar se tal superioridade procede. 
estamos deixando a astrologia dentro da Ciência! Tal crítica ao Critério de Popper, que se soma à crítica feita por Kuhn, pode ser encontrada em Agassi (1991), Hansson (2006) e em Mahner (2007). Em outras palavras, é perfeitamente possível algo ser não-falseável e não ser uma pseudociência. Mahner (2007, p. 548) propõe o termo paraciência ("parascience") para estas últimas.

Com relação à Metafísica, é exatamente esse equívoco que Pigliucci faz em outras partes de seu artigo: para ele, Metafísica e pseudociência são sinônimos. Sua crítica reside no fato de que Laudan rejeitou completamente o critério de falseabilidade e até mesmo o uso do termo "pseudociência". De fato, talvez isso tenha sido um exagero por parte de Laudan. O Critério de Falseabilidade tem um uso na Ciência: apesar de não ser um determinante absoluto para abandonarmos teorias falhas (afinal, todas as teorias são falhas), ele permite, ao menos, compararmos teorias com relação ao seu conteúdo empírico.

O certo, porém, é que o Critério de Falseabilidade não é oficialmente um caracterizador, muito menos uma definição, do que é Ciência. A Ciência está repleta de afirmações não falseáveis. Ocorre que essas afirmações metafísicas normalmente não são colocadas em questão durante a pesquisa normal; debate-se e procura-se apenas por dados referentes à, digamos, parte empírica da Ciência. A grande questão é que as pseudociências realmente fazem afirmações empíricas (e, evidentemente, assim como a Ciência, adotam princípios metafísicos, ainda que mais vagos e sem consenso geral), mas não se preocupam em analisar e criticar essas mesmas afirmações.

E aqui vemos uma última característica das pseudociências: mesmo com inúmeros resultados desfavoráveis, os seguidores de alguma pseudociência tendem a continuar acreditando em sua veracidade. O modo padrão de agir das pessoas firmemente convictas é aquele de se escolher os fatos que pareçam suportar a ideia original, ao mesmo tempo em que se ignora os fatos que claramente são incompatíveis com ela. Krystal (1999, p. 8) trata amplamente sobre esse sentimento de "resistência aos fatos" presente na atitude geral dessas pessoas. Outra forma marcante de agir é o de afirmar a existência de controvérsias onde realmente elas não existem. Tais estratégias foram muito utilizadas na história da Ciência: desde a negação da Teoria da Relatividade na década de 1930 (Wazeck, 2009, pp. 268-9), passando pela negação dos efeitos negativos do tabaco - pesquisas essas 
patrocinadas pela própria indústria envolvida (Dunlap \& Jacques, 2013) - e chegando até os nossos dias com a negação do aquecimento global (Boykoff, 2008).

É verdade também que cientistas, e todo ser humano em geral, tendem a resistir à mudança e à refutação de suas ideias. Mas, um cientista que insiste em se recusar a aceitar que seus dados estão equivocados, tal como afirmava Kuhn (2012), no longo prazo normalmente será excluído do jogo da Ciência. Não existe qualquer tipo de paralelo desse tipo nas pseudociências: normalmente não são feitos testes de confronto pelos seus próprios praticantes; e quando os cientistas os fazem, os seus defensores tendem a ignorar os resultados.

Com relação à postura que poderia ser adotada frente à pseudociência, utilizarei como exemplo uma cena do filme Interstellar $(2014)^{91}$. Em uma das primeiras cenas, durante um café da manhã, a pequena Murph, que está tendo problemas com fenômenos estranhos em seu quarto, diz aos presentes sobre um "fantasma" que a incomoda. Seu irmão mais velho Tom zomba-lhe, dizendo não passar de bobagem. Seu pai, o engenheiro, cientista e ex-piloto da NASA Joseph Cooper, inicialmente diz simplesmente que "fantasmas não existem". Após a insistência de Murph, "Coop" lhe dá uma chance, dizendo para que seja como uma cientista e não pare na afirmação de que é um "fantasma", devendo observar e registrar todos os dados e informações que puder acerca dos fenômenos que tem presenciado e daí tirar conclusões. E foi o que a menina fez: realizou anotações, identificou padrões e forneceu uma base para que, mais adiante, a verdadeira natureza do "fantasma" pudesse ser conhecida.

Poderíamos simplesmente agir da mesma maneira com os astrólogos, coachs quânticos, ufólogos, terraplanistas, ozonioterapeutas etc. Se querem ser vistos como cientistas, que adotem os métodos que Ihes são próprios. Que investiguem, que coletem dados, que ofereçam meios de demonstração independente, que tirem conclusões reprodutíveis, que encontrem padrões que difiram grandemente dos "padrões de placebo" etc.

Essa sugestão indica o caminho do saber: o do confronto de ideias, o do confronto dialético. Ataques pessoais, ofensas e até mesmo censura são, ao meu ver, completamente incompatíveis com a postura científica. Há muitos que querem proibir ou calar à força as pseudociências. Melhor seria expor ao público a fragilidade de suas afirmações, e ao mesmo tempo encorajar seus próprios praticantes a adotarem a

${ }^{91}$ Relato sem spoilers. 
atitude investigativa que é tão própria da Ciência.

De forma geral, as pseudociências acima citadas são inofensivas; dificilmente alguém tomaria uma atitude drástica em sua vida utilizando-se das afirmações vagas do horóscopo que leu na tela do metrô enquanto ia para o trabalho em uma manhã de terça-feira. Crer em óvnis ou na Terra plana pode soar ridículo para muitos, mas, de forma geral, tais ideias são realmente inócuas e não deveriam parecer ameaçadoras a ninguém. Não há porque confrontar essas ideias com agressividade, da mesma forma como não o fazemos com crianças que insistem em acreditar numa fábula qualquer.

Relativamente poucos trocariam o tratamento medicinal padrão por um tratamento puramente alternativo ${ }^{92}$, e se o fizesse, seria por sua própria conta e risco, usando de sua própria liberdade. Até porque tais tratamentos, assim como a maioria das pseudociências, não é uma crença comum entre pessoas de baixa instrução93. Essas últimas, em sua maioria, sequer sabem o que é isso. Podemos e devemos alertar sobre os riscos de uma escolha como essa, mas forçar um adulto autônomo a adotar um tratamento médico qualquer parece violar o mais básico princípio ético de liberdade. Esse ponto, aliás, poderia render um excelente debate em sala de aula e retornarei a ele mais adiante.

\subsection{5 - Comentários sobre o Terraplanismo e o Movimento Antivacina}

O terraplanismo merece um comentário diferenciado, uma vez que se trata mais de um movimento anticiência do que uma pseudociência. Em geral, as pseudociências não negam as afirmações científicas, mas as distorcem ou extrapolam seus limites. Os astrólogos em geral não veem inconveniente algum em utilizar os dados e os avanços obtidos pelos astrônomos. O Movimento da Terra Plana ${ }^{94}$, por sua vez, nega alguns dos conceitos mais básicos da Astronomia e da Física, a

92 Não me refiro a tratamentos tradicionais simples, tais como os chás da cultura popular. Refiro-me a tratamentos surgidos recentemente, com viés científico, mas efetivamente se encontrando no campo da pseudociência, tal como a ozonioterapia.

${ }^{93}$ Esse dado vem da minha própria experiência com o público em questão, uma vez que desconheço alguma pesquisa oficial que confirme estatisticamente tal afirmação.

${ }_{94}$ Os que tiverem maior interesse em conhecer o que o movimento defende, podem saber mais em https://epoca.globo.com/sociedade/8-ideias-propagadas-pelos-palestrantes-daconvencao-nacional-da-terra-plana-24075213. 
começar pelos tamanhos do Sol e da Lua, assim como suas distâncias e posições (o terraplanismo adota uma espécie de geocentrismo); negam também a gravitação, tanto a de Newton quanto a de Einstein, embora exista uma leve tendência ao aristotelismo; além de toda a cosmologia envolvendo a existência e a natureza dos outros planetas, estrelas e galáxias. Tal cosmologia não tem qualquer lugar nessa teoria "alternativa".

O melhor caminho, mesmo em casos extremos como esses, continua sendo o da argumentação. Censurá-los ou hostilizá-los é um erro e nenhum cientista deveria descer a esse nível tão baixo. A vida do buscador do conhecimento é uma vida de reflexão, uma vida de serenidade. É verdade que a discordância faz parte do processo dialético ${ }^{95}$ que construiu a Ciência. Mas tais discordâncias foram sempre resolvidas em torno de mesas de debate, de lousas cheias de demonstrações e em laboratórios, jamais em tribunais, ou em duelos de ofensas, ou de espadas.

O movimento antivacina também é diferenciado e precisa ser analisado em separado ${ }^{96}$. As vacinas são atualmente impostas às pessoas, com pouca ou nenhuma informação acerca de sua composição, processos de fabricação, possíveis efeitos colaterais etc. Não deveria ser de se espantar que algumas pessoas se recusem a ser vacinadas (ou a vacinarem seus filhos). Ao contrário, vejo como espantoso o fato contrário: o de a esmagadora maioria das pessoas aceitarem ter um líquido completamente desconhecido injetado em seus corpos unicamente porque o Estado Ihes disse que assim deve ser. Numa pesquisa realizada por Massarani, Leal e Waltz" ${ }^{97}$, "com base na coleta dos 100 links mais compartilhados, curtidos e comentados entre maio de 2018 e maio de 2019, por meio da palavra-chave 'vacina'", notaram que a disposição pró-vacina correspondeu a $87,6 \%$ do material analisado. Novamente, para mim tal dado é espantoso. Quantas pessoas pró-vacina realmente a compreendem? Quantas aceitam as aplicações apenas por ser obrigatória, ou

\footnotetext{
${ }^{95}$ Até o simples uso da palavra "dialética" aqui poderá causar discordância!

${ }^{96}$ Deixo claro que a maior parte desse trecho acerca das vacinas foi redigido entre novembro e dezembro de 2019, um tanto antes da eclosão da "corona crise". Isso significa que não fui influenciado por nenhum lado político da patética "guerra das vacinas" que estamos vivendo no Brasil no final de 2020. Baseio minha argumentação unicamente nos meus conhecimentos científicos e filosóficos (em especial, no uso da Guilhotina de Hume e numa ética de respeito às liberdades individuais).

${ }^{97}$ MASSARANI, L.; LEAL, T.; WALTZ, I. O debate sobre vacinas em redes sociais: uma análise exploratória dos links com maior engajamento. Cad. Saúde Pública; 36 Sup 2:e00148319, 2020.
} 
simplesmente por terem ouvido falar que isso é bom?

Na prática, se as vacinas funcionam, é irrelevante a motivação de uma pessoa ao decidir tomá-la: ela estará imunizada de toda forma. O que aponto aqui é para como a autoridade científica ganhou a confiança de tantos leigos, a ponto de aceitarem, mesmo sem conhecimento, terem uma substância injetadas em seus corpos. Bagdonas, Zanetic e Gurgel (2014, p. 253) falam sobre a importância de se reconhecer "os perigos oriundos da confiança cega" na autoridade científica. Não só os leigos, mas mesmo cientistas, supondo que pertençam a uma área distante da biologia patológica, deveriam buscar se informar criteriosamente sobre tudo o que envolve a produção de vacinas, antes de defendê-las cega e unicamente porque a visão cientificista de nosso tempo nos coage a isso ${ }^{98}$.

A realidade é que a informação nessa área é demasiado "esotérica", e mesmo as explicações oferecidas pelos livros didáticos, professores e divulgadores costumam ser superficiais e duvidosas ao exame crítico $^{99}$. Como poucos fazem esse exame, resulta que a maioria da população apenas aceita que precisa da vacinação. 0 sentimento antivacina começa quando se dá mais um passo e começa-se a questionar a informação escassa que é disponibilizada acerca das vacinas. A única solução viável que vejo para esse problema é incentivar esses questionadores a também darem um passo a mais (ou seja: estudar mais sobre o assunto). Assim, as próprias estatísticas realizadas no campo das vacinas farão (ou, em tese, deveriam fazer) o trabalho de convencê-los.

O valor das vacinas como forma de combate a doenças, cujo volume de evidências empíricas apenas aumenta com o tempo, dificilmente pode ser posto em

${ }^{98}$ Sinto no ar também um certo temor de defender certas posições devido ao medo de ser associado a pessoas e a ideologias das quais discordamos, mas que por acaso também defendem tais posições específicas (ainda que, eventualmente, as defendam por motivos diferentes). Esse tipo de confusão, tão típica de nossos dias, em que posições ideológicas são vistas como grandes pacotes em que devemos ou aceitar tudo (se queremos fazer parte do time) ou negar tudo (se queremos fazer parte do time adversário), a mim parece mais como um tipo de loucura. Recuso-me veementemente a participar desse jogo.

${ }^{99}$ Peço ao leitor que reflita por um instante: Você é a favor das vacinas? Se você tiver escolha, você pretende se vacinar contra a COVID-19? Se sim, você sabe como as vacinas contra COVID-19 estão sendo feitas? Conhece os métodos de produção, as substâncias que as compõem, a origem dessas mesmas substâncias etc.? Você confia em todas as instituições, governos, agências de saúde, de divulgação, de logística etc. envolvidas no processo? Você saberia explicar, para alguém que lhe perguntasse, o motivo de tal vacina ter conseguido se desenvolver tão rapidamente (quando comparada a outras tantas vacinas que demoraram muitos anos, e outras que, mesmo com décadas de pesquisa, ainda não foram desenvolvidas)? 
dúvida. Ninguém realmente deseja que a varíola, a coqueluche e a rubéola voltem a assolar a humanidade, condenando-nos a uma morte prematura e perfeitamente evitável. Porém, em um mundo em que essas doenças foram total ou parcialmente erradicadas, parece que reações alérgicas pontuais de algum vacinado conhecido têm maior impacto no imaginário popular, causando desconfiança com relação às vacinas. Essa é apenas uma das possíveis causas para o aumento do sentimento antivacina; por exemplo, Massarani, Leal e Waltz (ibidem, pp. 2-3) também identificam como causas: (a) "a suposta correlação do preparo da vacina com males de causa pouco conhecida", (b) "minimização da gravidade das doenças infecciosas", (c) "insinuações sobre a presença de compostos mercuriais", (d) "defesa das liberdades civis em vista do caráter compulsório da vacinação" e (e) "apelo à resistência contra as lucrativas corporações farmacêuticas".

Todavia, completo eu, que não são apenas casos desse tipo que tornam pessoas avessas às vacinas. Há (f) pessoas que podem não querer ser vacinadas por questão de princípios filosóficos ou religiosos. Elas não necessariamente são pessoas contrárias à Ciência ou que duvidam de sua eficácia.

Com relação aos pontos acima citados, poderíamos combater os pontos (a), (b) e (c) com mais estudos, mais pesquisa, mais ensino e divulgação de qualidade, além de maior transparência com relação a tudo o que envolve a produção das vacinas. Entendo como sendo o principal terreno onde nós, como educadores de Ciências, podemos atuar.

O ponto (e) é curioso. Embora haja, sim, pessoas que neguem as vacinas por acreditarem que elas não passam de uma forma de grandes corporações lucrarem de forma exorbitante, é também muito fácil achar na rede pessoas que se identificam como "de esquerda", mas que parecem não estranhar que a vacinação em massa implica em tal lucro massivo para as farmacêuticas, algo que normalmente pessoas de tal espectro político considerariam imoral. Por fim, os pontos (d) e (f) são, ao meu ver, os mais delicados. Eles abrem margem para um debate ético da mais suma importância que, por mais difícil que seja o trato com o assunto, precisa ser abordado amplamente nas salas de aula e nos ambientes de divulgação: a questão da ética por trás da obrigatoriedade da vacinação.

O Estado ou outra pessoa (como os pais com relação aos seus filhos) deveria ter o poder de obrigar alguém a ingerir ou injetar qualquer substância em seu próprio 
corpo? Alguns argumentam que as pessoas não vacinadas são um perigo para toda a sociedade, pois elas farão as doenças que estão sendo combatidas retornarem. Um contra-argumento possível é: se tais doenças retornarem, apenas as pessoas não vacinadas serão afetadas (ou seja: as pessoas que escolheram voluntariamente não serem vacinadas). Por exemplo, está havendo um aumento na incidência do sarampo nos EUA, doença essa considerada controlada desde 2000 (Massarani, Leal \& Waltz, 2020, introdução). Isso coincide com um período de aumento de desconfiança dos americanos com relação às vacinas (de 19\% para 50\% entre 2000 e 2009) (ibidem). Os autores afirmam, na mesma página, que a não vacinação representa não apenas um risco pessoal; porém, daí não decorre a conclusão de que toda a sociedade estaria em risco - é, de fato, um risco coletivo, mas apenas para o coletivo dos "não vacinados". Se toda a população mundial estivesse contaminada com sarampo, exceto uma pessoa, no caso de ela se vacinar, em tese, tal pessoa deveria ser imune e não teria que se preocupar em ser infectada ${ }^{100}$.

Os citados pesquisadores mencionam, por exemplo, o medo e o ceticismo em relação às vacinas como fatores relevantes para se compreender a questão (ibidem). O medo é combatido com conhecimento. Já o ceticismo não deveria ser visto intrinsecamente como um problema. O ceticismo para com tudo é a atitude crítica mais poderosa a ser considerada como salvaguarda contra o erro, além de sempre ser exaltado por amantes da Ciência como uma de suas características fundamentais, uma verdadeira virtude do buscador do conhecimento. Isso de sermos agudamente céticos acerca de certos assuntos, enquanto aceitamos passivamente outros, tornando, assim, o ceticismo algo seletivo e arbitrário, não seria uma forma débil de ceticismo? Reflexões...

Alguns veem como erro grave utilizarmos a Ciência como justificativa para medidas estatais autoritárias, tais como a vacinação obrigatória. É fácil imaginar um cenário em que outras injeções, ingestões, implantes etc., dessa vez com intenções realmente duvidosas (para dizer o mínimo), tornam-se igualmente obrigatórios

\footnotetext{
100 Meu objetivo com tal argumentação é o de entender o pensamento de quem se posiciona contra as vacinas, tentando identificar a estrutura de seus argumentos, para que, então, seja possível traçar uma estratégia de convencimento de tais pessoas. Faço isso após presenciar tremendas intransigências para com elas, sendo frequentemente e de forma automática taxadas de "ignorantes", "obscurantistas", "fanáticas", o que apenas contribui para um aumento do sentimento antivacina, afastando-as ainda mais de querer estudar o assunto e, possivelmente, convencerem a si mesmas a se vacinarem. Enfatizo: defendo que as pessoas devam ser convencidas, e não obrigadas, a se vacinarem.
} 
seguindo os mesmos argumentos que embasam a vacinação obrigatória. Talvez, esse seja um poder grande demais para um Estado possuir, cujas atribuições, de acordo com essa perspectiva, não deveriam passar por cima das liberdades individuais. Lembremos da volatilidade da democracia: se hoje estiver no poder um governante qualquer, alinhado com nossa posição política (o que inclui, é claro, o uso político do conhecimento científico), amanhã poderá estar um governante de posição radicalmente oposta, mas tendo ao seu dispor todo o poder da máquina estatal conquistado nas gestões anteriores.

Constitui cientificismo utilizar-se da Ciência para se tomar decisões éticas. A Ciência pode demonstrar que fumar faz mal à saúde, mas isso não diz se deve-se ou não proibir que um adulto tenha a liberdade de fumar se assim ele quiser. Porém, vemos constantemente tentativas de se ignorar a Guilhotina de Hume e usar evidências científicas/empíricas para derivar e justificar legislações e decisões éticas, como quando estão em jogo certos assuntos controversos (aborto, eutanásia, testes em animais etc.). Uma boa discussão a respeito pode ser encontrada em Haack (2012, pp. 89-92).

Esse tipo de discussão ética é demasiadamente complicada para que eu me estenda mais nesse assunto no presente trabalho. Concluirei lembrando que esse debate precisa ser feito. O professor e o divulgador de Ciências possuem posição privilegiada nesse debate; é parte de sua função social transmitir o conhecimento que convencerá aqueles que precisam ser convencidos, sempre pela via argumentativa e com fundamento na realidade. Não podemos esperar, de braços cruzados, que nossos políticos, os quais em sua maioria não possuem conhecimento científico algum, tomem essas decisões por nós. Reforço que acredito apenas no caminho da informação, da educação e da argumentação, e nunca no caminho da imposição. Essa é uma precaução necessária para conter os avanços tanto da anticiência, quanto da pseudociência e dos movimentos que visam transformar a Ciência em dogma ou em fonte de justificativas para atos no mínimo questionáveis, quando não espúrios e condenáveis. 


\section{CAPÍTULO II - O PROGRESSO DA CIÊNCIA}

Após essa longa discussão acerca dos elementos constitutivos da Ciência, o próximo passo é abordar como a Ciência evolui. Esse é um ponto delicado e esconde complexidades geralmente ignoradas. Como veremos, muitos divulgadores ressaltam o caráter dinâmico da Ciência, exaltando o fato de que teorias podem ser substituídas por outras melhores e mais precisas. Ao mesmo tempo, falam sobre essas mesmas teorias, que atualmente são aceitas, como se elas tratassem de fatos consumados e indubitáveis (ou quase indubitáveis). Considero impressionante como um astrofísico consegue se dirigir a uma plateia de entusiastas e afirmar que o "Universo teve o seu início em uma enorme e súbita expansão há cerca de 13,8 bilhões de anos" com a exata mesma naturalidade com que diria que "a água mata a sede" ou "a comida mata a fome". Concordo que, com os meios que dispomos, temos modos razoáveis para crer que realmente assim foi. Mas, se realmente assim foi, onde fica o caráter dinâmico da Ciência? Que espaço há para uma visão diferente de Cosmo? Que espaço há para novidades? E, se há abertura para novas ideias contestarem as antigas, por que as afirmações atuais são feitas com tamanha veemência, em tom de certeza? Por que não são ressaltadas as fragilidades de nosso conhecimento, passando ao público a autêntica humildade que a Ciência proclama ter, em vez de superestimar a validade de suas teorias?

Oferecer alternativas a essa visão cientificista está no cerne dos desafios da educação científica da atualidade. Isso, em grande parte, já foi realizado no capítulo anterior, porém há algo importantíssimo que foi apenas pontualmente comentado, e que será o foco do presente capítulo - a já citada questão da mudança científica.

Ao menos desde Comte, os filósofos e historiadores da Ciência buscam entender como a Ciência progride. O historiador da Ciência George Sarton chegou a afirmar (1936) que o progresso é justamente a característica distintiva entre a Ciência e todas as demais áreas de conhecimento ${ }^{101}$. Mais tarde, outros filósofos questionaram tal exclusividade, e até mesmo o próprio conceito de progresso.

Um grande nome do século XX neste campo foi Thomas Kuhn. As perguntas

${ }^{101}$ Essa posição lembra a do médico português cuja entrevista foi citada anteriormente, que afirmou categoricamente que "só a Ciência progride". Conforme comentei naquela ocasião, considero essa uma afirmação vazia. 
centrais realizadas nessa área são: o que faz a Ciência evoluir? Ela está evoluindo em alguma direção específica? Se sim, será possível saber qual é essa direção? (Ou, visto de outro modo, é possível prever os próximos passos que a Ciência dará?) Acrescento aqui outra questão que, embora eventualmente abordada pelos filósofos da Ciência, ainda está longe de possuir resposta clara: existe uma atitude que possamos adotar ativa e conscientemente a fim de tornar o avanço da Ciência mais veloz? Buscarei esboçar uma resposta para esta última pergunta ao longo das seções que se seguem.

\section{1 - As fases da Ciência de acordo com Comte}

Na rara pérola chamada O Trivium, diz Miriam Joseph (p. 150):

"[...] devemos lembrar que a mente humana é feita para a verdade e que instintivamente busca a verdade; que a mente frequentemente aceita o erro por não distingui-lo do que vem com ele; que é raro a mente aceitar aquilo que é totalmente errado e nada daquilo que é verdadeiro; e que nunca aceita o erro exceto quando há má apreensão daquilo que é verdadeiro."

Uma pessoa dedicada ao saber, que elabora uma ideia filosófica ou científica, dificilmente estará errada em absoluto. Não há por que uma pessoa inteligente e que, de forma sincera, busca o conhecimento, se enganar totalmente e criar uma doutrina completamente descartável. Faço essa ressalva inicial, pois venho apontado as diversas críticas que o Positivismo de Comte recebeu desde que foi proposto. Contudo, sua classificação das Ciências, assim como a descrição de suas fases de desenvolvimento, se tomarmos as devidas ressalvas, podem ser usadas como ponto de partida para compreendermos como se deu o progresso da Ciência.

A visão de Comte é basicamente a de progresso acumulativo: a Ciência avança somando-se mais e mais "verdades comprovadas empiricamente" ao seu arsenal. Para ele ${ }^{102}$, o conhecimento humano passa por três fases, os chamados Estágios

${ }^{102}$ A referência que usei para escrever todo esse trecho foi o seu Curso de Filosofia Positiva. Ver referências. 
Teológico, Metafísico e Positivo. Ele expandiu essa ideia para além do progresso do conhecimento, atribuindo esses três estágios ao desenvolvimento da sociedade humana como um todo. Todavia, o foco aqui será no desenvolvimento da Ciência, especificamente.

Cada estágio é subdividido em fases; em prol da síntese, resumirei as principais características de cada um. No Estágio Teológico, predominam as explicações místicas para os fenômenos, atribuindo a seres sobrenaturais, deuses e demônios os efeitos visíveis no mundo. O Estágio Metafísico corresponde à investigação filosófica e racional desses mesmos fenômenos; mas Comte, devido à ênfase desse estágio em se buscar "as causas" (lembremo-nos das quatro causas metafísicas de Aristóteles), considerava a busca metafísica como inútil. Isso, pois, já se tinha como definido que seria impossível encontrar respostas definitivas para explicar tais causas. David Hume já havia demonstrado a dificuldade existente em se afirmar que um evento qualquer era causado por, ou era causa de, outro. O próprio Newton já havia desistido da busca por compreender as causas (ao menos, as causas mais profundas - em específico, as causas finais), focando sua atenção na descrição de seus efeitos. Dessa forma, o Estágio Metafísico era, para Comte, uma mera transição para o estágio final e atual, o Estágio Positivo. Nele, tendo abandonado toda crença mística e teológica, assim como a busca por causas primeiras, metafísicas, para os fenômenos, os cientistas estariam inteiramente dedicados a descrever os fenômenos da Natureza, para assim compreender a ordem no mundo e realizar previsões.

Assim, Comte objetivou aniquilar a Teologia e a Metafísica, reduzindo a religião a nada ${ }^{103}$ e a tarefa da Filosofia a uma mera classificação das Ciências, tal como a classificação que ele próprio fez na condição de filósofo. Como já comentado anteriormente, não há como aniquilar absolutamente a Metafísica da Ciência. Com relação à Teologia, ainda é possível ver seus traços em modernas teorias físicas. A teologia grega afirmava que seus deuses, especialmente os das primeiras gerações de acordo com Hesíodo, eram personificações das forças e dos elementos primordiais da natureza. Tirando o fato de que os gregos não estavam tão preocupados com verificações empíricas quanto estamos hoje, vemos ainda os resíduos teológicos dessa antiga visão quando afirmamos que todas as "leis da natureza" são governadas

${ }^{103}$ Exceto pelo importante detalhe que ele próprio fundou a sua própria: a Religião da Humanidade. 
por quatro (ou três, ou quantas sejam) "forças fundamentais", ou que toda a matéria é constituída de "partículas elementares", ou ainda quando falamos de "massa e energia" etc. Os métodos são profundamente diferentes, mas as ideias primeiras parecem apenas ter trocado de nome. Em outras palavras, o programa de Comte falhou em sua tentativa de "purificar" o saber humano. Infelizmente, a sua influência foi e continua sendo muito grande. Muitos cientistas, professores e divulgadores expressam abertamente os ideais positivistas, alguns sem saber que o estão fazendo. Identifico o positivismo como a fonte de onde se originou o cientificismo.

Poderia ter sido diferente a história do conhecimento humano caso Comte não tentasse eliminar a Teologia e a Metafísica, mas tivesse visto toda essa questão do ponto de vista do continuum que propus em uma seção anterior: as teorias não precisam ser classificadas de forma absoluta como "teológicas", "metafísicas" ou "científicas/empíricas/positivas". Podemos simplesmente imaginar um gradiente, com os extremos ocupados pela Teologia e pela Ciência, e o meio dominado pela Metafísica ${ }^{104}$. As teorias nascem como descrições de tal forma abstratas que podem ser classificadas como teológicas ${ }^{105}$; depois, tornam-se gradualmente metafísicas com a articulação racional de suas prováveis causas e de seus deduzidos efeitos; e, por fim, adquirem o caráter predominantemente científico/empírico, assim que ficam claros quais são os primeiros testes que devem ser realizados e quais dados devem ser coletados para corroborá-la ou falseá-la. Embora a Teologia possa ser encontrada somente como sutis traços nas teorias mais empiricamente corroboradas da atualidade $^{106}$, a Metafísica é encontrada em maior grau, comparativamente falando. Uma teoria pode ser vista, então, como uma onda ou um pulso centrado em um ponto do continuum, caminhando gradualmente da Teologia para a Ciência Empírica, passando pela Metafísica como intermediária.

Para Comte, porém, essa classificação não era assim, mas, como já dito,

\footnotetext{
${ }^{104}$ Considerando a descrição de Filosofia que Russell fez (ver a citação da página 68), como estando na "terra de ninguém" entre a Teologia e a Ciência, essa visão do continuum pareceme cada vez mais razoável. Massimo Pigliucci (2013) também propõe algo nessa direção.

105 À época em que escrevi essas linhas (novembro/dezembro de 2019), saiu a notícia da evidência de uma $5^{\text {a }}$ força da natureza. Não vejo diferença em chamá-la de "Força Fundamental", ou de "Nix", "Uranus", "Éris", "Gaia" etc. Esse conceito de "Força Fundamental", que seria responsável pela ordem visível no mundo, é em essência o mesmo para Homero e para o cientista moderno. O diferencial, novamente, está mais no método do que na natureza essencial do conceito.

${ }^{106}$ É claro que isso é, grandemente, uma questão de interpretação. Muitos discordarão com relação a isso.
} 
poderia ser bem determinada, com linhas demarcatórias mais definidas. Nesse ponto, Popper, mesmo sendo um grande crítico do positivismo, se aproxima de Comte, pois a sua divisão pelo Critério de Demarcação estabelece justamente esse tipo de linha fronteiriça - não entre ciências, mas entre Ciência e não-Ciência.

Comte estabeleceu que as diferentes ciências nasceram no Estágio Teológico, e foram ao longo do tempo passando para o Estágio Metafísico, e se convertendo, ao fim, ao Estágio Positivo, porém em tempos diferentes. A Astronomia, para ele, foi a primeira a fazê-lo, tendo iniciado no animismo e na astrologia da antiguidade, e tendo atingido o Estágio Positivo com a formulação da Lei da Gravitação Universal de Newton. Essa última fornecia a descrição da força que poderia ser utilizada para prever o estado futuro do movimento dos corpos celestes, sem a intenção de explicar a origem dessas forças ou por que ela funciona dessa forma e não de outra. O criador do Positivismo parece ter acreditado que a teoria de Newton estava livre da Metafísica, mas essa última esteve, no máximo, tão somente despreocupada com o debate metafísico que a envolve ${ }^{107}$. A Metafísica está lá, nos próprios conceitos de massa, de força, de movimento e de espaço e tempo absolutos (e na causalidade, na nãolocalidade da transmissão "instantânea" da força pelo espaço, e na... etc.). A teoria só parece ser inteiramente empírica se ignorarmos que esses termos não possuem definições triviais, e que só são úteis quando assumimos, por meio da Filosofia e da Metafísica, alguma concepção prévia, a nível de axioma e de ontologia, acerca deles. Esses conceitos só foram desafiados, a ponto de colapsarem, com Einstein, muito tempo depois, demonstrando que, necessariamente, a nova teoria também tinha raízes metafísicas - afinal, Einstein não poderia ter derrubado tais conceitos se não tivesse preparado substitutos, de mesmo tipo, para colocar no lugar.

De qualquer maneira, a Astronomia, devido à sua relativa simplicidade quando comparada a outras Ciências, acabou sendo a primeira a receber um corpo teórico sólido que nos habilitasse a realizar previsões verdadeiras acerca do mundo natural. As outras Ciências se desenvolveram, dessa maneira, com velocidade diretamente proporcional à sua simplicidade: A Astronomia, a mais simples, se desenvolveu primeiro, sendo seguida pela Física, pela Química, pela Biologia e pela Sociologia sendo essa última a mais complexa e, por isso, a mais lenta em seu desenvolvimento.

107 Não acredito nisso. Newton era bastante consciente da Metafísica envolvida em seu trabalho. 
É claro que o universo da Ciência é certamente muito mais complexo do que isso, e desde o surgimento do Positivismo no início do século XIX, notáveis avanços nos forçam a considerar alterações. Devemos levar em conta, por exemplo, que há grandes regiões onde as diferentes ciências se fundem; a Astrofísica, a FísicoQuímica e a Bioquímica são alguns exemplos. É preciso lembrar também que a Sociologia, até o momento, continua distante do nível de empirismo já atingido pelas demais (embora isso, de certa forma, encontre apoio na visão de Comte).

Certas áreas da Biologia, como a da Origem da Vida e, em estágio mais avançado, a Teoria da Evolução, estão aos poucos acumulando mais conteúdo empírico, que deverão levá-las até o grau que as principais teorias da Química e da Física já atingiram. $O$ incremento de conteúdo empírico está diretamente relacionado com o avanço tecnológico dos instrumentos de investigação: se no início dispúnhamos tão somente de nossos cinco sentidos, toda a gama de aparatos e instrumentos de medida que foram inventados ao longo da história permitiram com que nós pudéssemos coletar informações antes completamente inacessíveis. Sem esse avanço técnico, a Ciência Empírica jamais teria progredido da forma, com a velocidade e na direção em que progrediu. Comento mais sobre a relação entre desenvolvimento científico e desenvolvimento tecnológico na seção 2.5 .

Toda essa abordagem é apenas uma entre as possíveis e certamente não está livre de críticas. Laudan problematizou a postura de utilizar exemplos históricos como base para se confirmar visões filosóficas acerca do progresso da Ciência (Laudan et al., 1993):

"Fiéis a suas inclinações empiristas, esses teóricos da mudança científica salpicam à vontade seus escritos filosóficos com referências a exemplos históricos tendo em vista apoiar as afirmações que fazem. Mas a todos, exceto os discípulos mais engajados, esses exemplos frequentemente parecem desempenhar um papel mais decorativo ou ilustrativo do que probatório. De fato, do modo como normalmente se apresentam, tais exemplos são extremamente breves e derivados de material secundário para que possam desempenhar efetivamente o último papel. Casos científicos históricos ou contemporâneos são tipicamente aludidos apenas de passagem. Mesmo quando um caso é considerado em algum detalhe, raramente um autor compara a adequação de seu modelo favorito com a de seus rivais. Nenhum sério esforço de sofisticado planejamento empírico das situações de teste pode ser encontrado na maior parte dessas discussões. 
Em particular, e mais obviamente, é normalmente o inventor, e daí o advogado, de modelo que traz evidências para sustentá-lo, levantando questões de neutralidade e objetividade. Na melhor das hipóteses, os autores poderão dizer 'veja como minha teoria está bem adequada a esse punhado de casos'. Apesar dessa atuação perfunctória, a conclusão que normalmente se extrai é que a teoria em questão está 'apoiada' pelos relatos históricos."

Poderíamos concluir, a partir dessa citação, que os métodos utilizados pelos filósofos da Ciência estão contaminados pelo viés de confirmação, pois buscam em exemplos históricos evidências de suas ideias. Porém, ainda que sejam necessários aprofundamentos históricos para se testar essas abordagens filosóficas acerca da mudança científica, alguns fatores são muito claros e não podem ser desconsiderados. Não podemos ignorar que as teorias históricas de mudança científica fornecem, de fato, um quadro que nos permite compreender melhor essas mesmas mudanças. Elas perfuram o véu do senso comum, senso esse que ensina ser a mudança na Ciência um processo simples, honesto, de substituição de teorias inadequadas (ou "falsas" ou "não científicas") por teorias melhores, "mais de acordo com os fatos" etc. Mas, para além de proporcionar a superação dessa visão reducionista, é evidente que essas novas visões (hoje, nem tão novas: algo mais que meio século se passou desde as primeiras aparições dessas teorias) precisam ser testadas e o próprio Laudan e sua equipe ressaltam a importância da tarefa. De todo modo, Laudan afirma ser a contribuição de Kuhn a mais importante e é a abordagem que adotei para esta dissertação.

Dando prosseguimento, a análise que foi feita aqui, até o momento, nos dá importantes compreensões sobre o progresso da Ciência. A primeira delas é a ausência de limites bem definidos entre as diferentes ciências. A segunda, é o fato de que uma ciência progride através do tempo em direção ao aumento de conteúdo empírico ${ }^{108}$, reduzindo gradualmente as influências teológicas e metafísicas de suas concepções, porém sem jamais extirpá-las completamente. Muitos foram os filósofos que tentaram desvendar os rumos da Ciência. Comte acreditava realmente ter descoberto a lei que governava esse progresso, a ponto de estendê-la para toda a sociedade e criar a sua própria "religião científica". Ao que tudo indica, não há resposta

${ }^{108}$ Essa aparente linearidade será problematizada logo adiante. 
definitiva para essa questão, mas, sim, várias abordagens possíveis. A seguir, veremos a contribuição de Kuhn com relação a essa questão.

\section{2 - As fases da Ciência de acordo com Kuhn}

Depois de Comte, o filósofo que deu a contribuição mais relevante para o entendimento do progresso científico e da classificação das ciências foi Thomas Kuhn. A Estrutura das Revoluções Científicas, a base de referência para a escrita da presente seção, deu início a toda uma tradição de pesquisa em História e Filosofia da Ciência, em especial no que diz respeito ao progresso científico. Suas ideias, no entanto, são bem menos lembradas no ambiente científico brasileiro, tanto em ensino quanto em divulgação (tal como abordarei no Capítulo III), quando comparamos com as influências positivistas e até mesmo com o Critério de Popper. Espero que o presente trabalho indique uma maneira de mudar essa situação, que é a responsável por perpetuar erros que, há dois séculos, permanecem permeando o pensamento científico do praticante e do leigo.

O conceito chave para se entender a evolução da Ciência sob a ótica kuhniana é o paradigma. Paradigma, em uma palavra, é um consenso. Em particular, trata-se do consenso acerca das perguntas que o grupo deseja investigar, das premissas ou axiomas aceitos por aquela comunidade, e dos métodos considerados adequados para a investigação. Para Kuhn, uma ciência nasce quando o seu primeiro paradigma é estabelecido. Antes de isso ocorrer, tem-se a pré-história daquela ciência, ocasião em que diferentes grupos e escolas, praticando diferentes paradigmas, disputam a proeminência sobre os demais. É uma disputa pela sobrevivência ao estilo darwinista, visão que Popper também compartilhava à sua própria maneira. No momento em que alguma dessas escolas atinge tal patamar, as demais escolas tendem a desaparecer. Em alguns casos, como no da Astrologia, as escolas perdedoras seguem em paralelo às vencedoras até os dias de hoje, ainda que apartadas da comunidade científica ${ }^{109}$,

109 Lembro ao leitor que uso a palavra "ciência" com "c" minúsculo para designar campos específicos de conhecimento, mesmo que esses não sejam considerados como sendo parte das Ciências Empíricas. Refiro-me à Astrologia como ciência em clara oposição à Ciência 
digamos, principal. O prof. Martins (1993, p. 8), em seu excelente artigo sobre o debate entre as ideias de vácuo e de éter, é enfático:

"Na verdade, até hoje, há físicos que rejeitam a teoria da relatividade e defendem a existência de um éter. Mas estes são geralmente vistos pelos cientistas 'normais' como excêntricos e, às vezes, tratados como párias pelos seus colegas. São considerados como pertencentes ao mesmo grupo dos que defendem a teoria da Terra oca e outros absurdos semelhantes."

O próprio prof. Martins fornece uma argumentação fortíssima em seu artigo, defendendo ter sido uma má escolha da Ciência ter abandonado a ideia de éter. Ainda assim, se a comunidade em sua grande maioria rejeita uma ideia qualquer, independentemente de seu potencial, mas apenas por não fazer parte do paradigma aceito, quem a defender acabará se vendo apartado.

O quão vital é a aquisição de um paradigma à existência de uma determinada Ciência fica explícito nas palavras de Kuhn (2012, p. 106):

"[...] uma comunidade científica, ao adquirir um paradigma, adquire igualmente um critério para a escolha de problemas que, enquanto 0 paradigma for aceito podem ser considerados como dotados de uma solução possível. Numa larga medida, esses são os únicos problemas que a comunidade admitirá como científicos ou encorajará seus membros a resolver. Outros problemas, mesmo muitos dos que eram anteriormente aceitos, passam a ser rejeitados como metafísicos ou como parte de outra disciplina. Podem ainda ser rejeitados como demasiado problemáticos para mereceram o dispêndio de tempo."

E já que a Astrologia foi citada, cabe aqui um adendo com relação ao que chamamos de pseudociência. Como discutido no final do capítulo anterior, vários autores chamaram a atenção para algum aspecto que julgaram ser a maior diferença entre a Ciência e a pseudociência. Todos eles são válidos e correspondem, a seu modo, ao que é de fato. Mas, talvez, a característica que ressalta como termo comum a todos esses aspectos é que as pseudociências carecem de espírito investigativo. Sem esse espírito, que conduz inevitavelmente aos testes empíricos, é difícil discernir o paradigma que toda a comunidade deve seguir. Sem um paradigma unificador, resulta que aquele conhecimento converte-se permanentemente em uma pré-Ciência,

Empírica, ainda que ela seja normalmente denominada como pseudociência. Mera questão de nomenclatura. Ver próximo parágrafo. 
uma Ciência pré-histórica no sentido kuhniano, uma pseudociência no sentido moderno.

É forçoso estabelecer uma relação ou conciliação entre a classificação de Comte e a de Kuhn, dada a separação de tempo e de visão de mundo de ambas as propostas, mas é possível tentar. Parece-me que a passagem da pré-história para a história de uma ciência corresponde, em diversos aspectos, à passagem do Estágio Metafísico para o Estágio Positivo. É claro que, para essa última passagem, estou levando em conta não uma passagem brusca e determinada, mas uma mudança de predominância: considero a passagem a partir do momento em que o caráter empírico de uma teoria começa a se sobressair sobre o metafísico, mas sem a extinção dessa última, como sonhara Comte. Quando ocorre essa mudança de predominância, as diferentes escolas possuem ao menos um ponto de referência objetivo e testável de forma independente, no qual podem se basear e finalmente ter um parâmetro para decidir entre os diferentes paradigmas concorrentes. Aliás, a escolha entre paradigmas (ou entre teorias concorrentes) é o tema central quando o assunto é progresso científico.

Todo progresso na Ciência envolve trocas de princípios, de modelos, de hipóteses, de métodos, onde ideias antes consideradas adequadas são alteradas, limitadas, mutiladas ou completamente abandonadas. A mudança de teorias ou de paradigmas é um processo muito mais complexo do que o normalmente explicado pelos divulgadores ao público leigo. Tratarei em específico desse assunto na seção 2.4. O ponto principal a ser considerado aqui (e algo que é bem pouco abordado por divulgadores) é sobre como surgem novas ciências.

A astrobiologia e a teoria das cordas, por exemplo, ainda desprovidas de condições de verem suas afirmações empiricamente testadas, são fortes candidatas a serem incorporadas futuramente ao rol das teorias científicas mais bem consolidadas de nosso tempo. Isso ocorrerá assim que nossos meios técnicos e instrumentos de medição tornarem possível testar suas primeiras hipóteses. Também não é impossível que certas pseudociências, hoje muito desacreditadas, venham a ser classificadas como Ciências no futuro. Uma única nova descoberta pode abrir caminho para toda uma inédita gama de explicações para fenômenos antes atribuídos a supostas forças imponderáveis. Por esse motivo, reforço minha aposta de método de combate à pseudociência: não ridicularizando ou execrando, mas convidando a 
adotar as regras da Ciência, afim de se convencerem de seus equívocos, ou — quem sabe? - convencerem os cientistas dos equívocos deles.

A questão a ser examinada agora é saber qual é o trabalho científico padrão: o que a comunidade de uma Ciência faz em posse de seu paradigma. É necessário esclarecer esse ponto justamente pelas falsas concepções de como a Ciência é feita na prática, e como esse trabalho de rotina leva, em última instância, às crises que resultarão em mudanças de paradigma.

\section{3 - As tarefas científicas - O que um cientista faz?}

Até mesmo o leigo possui uma vaga ideia do que um cientista faz. É verdade que essa ideia normalmente é um tanto distante da realidade do trabalho científico, mas, segundo uma linha construtivista, é a partir dessa concepção original que os professores e divulgadores podem trabalhar e indicar o caminho para a correção. Para começar, vale relembrar uma citação mencionada na seção 1.3 desse trabalho (Kuhn, 2012, p. 89). Naquela citação, Kuhn revela uma crueza que normalmente vai de encontro ao senso comum do que se pensa ser um cientista. Ao contrário de alguém que constantemente está fazendo novas descobertas (ou, ao menos, em busca delas), a maioria dos cientistas está dedicado apenas a adequar as descobertas já realizadas até o momento às suas teorias previamente aceitas. Isso é o que Kuhn chamava de "ciência normal", onde a tarefa do cientista é resolver problemas (denominados por ele como quebra-cabeças), mas sem a intenção de gerar novidades. Laudan defende mesmo que a característica distintiva da Ciência é o seu empreendimento de resolver tais quebra-cabeças. O fato de isso ser tão pouco claro nos cursos de graduação, ou mesmo durante atividades de divulgação, constitui uma omissão de um aspecto fundamental do fazer científico. No Ensaio Introdutório d'A Estrutura, diz lan Haking com relação ao que é exposto no próprio livro (Kuhn, p. 20, 2012):

"Muitos leitores, cientistas atuantes, ficaram um tanto chocados, mas depois tiveram que admitir que é assim que as coisas ocorrem em boa parte 
de seu trabalho cotidiano. Problemas da pesquisa não visam a produzir efetivas novidades."

Lembremo-nos que nenhuma teoria é completa, nem mesmo na área em que supostamente deveria sê-lo. Nenhum paradigma dá conta de explicar todos os fenômenos que pretende explicar. Porém, a clareza nessa incompletude só se percebe no terreno do confronto com a realidade. É justamente essa incompletude que dá aos cientistas comuns uma tarefa a ser realizada: buscar, ao máximo, forçar os limites de aplicação de suas teorias. É como esticar um elástico. E da mesma forma como um elástico não pode ser forçado indefinidamente, uma teoria tampouco poderá. Cedo ou tarde, começarão a surgir as chamadas anomalias: fenômenos e dados que se recusam a enquadrarem-se aos estreitos limites da teoria.

Tomo como um exemplo uma descoberta feita durante a semana em que escrevo esse texto (Dezembro/2019): cientistas chineses descobriram em nossa galáxia um buraco negro gigante, com massa de aproximadamente 70 vezes a massa do sol ${ }^{110}$. Os modelos teóricos preveem valores próximos de 20 vezes a massa solar para esses misteriosos objetos cósmicos. Um objeto de 70 vezes a massa solar é certamente uma anomalia, um desvio de predição. Muitas das anomalias descobertas de maneira similar são facilmente resolvidas. A rigor, o Critério de Popper seria o suficiente para considerar uma descoberta dessa como uma falseadora da teoria. Mas o Critério não é aplicado dessa maneira. Como ressaltado por Kuhn, há uma resistência natural à mudança. Creio que essa resistência é, em parte, devido a um certo padrão psicológico humano fundamentado na busca por segurança. Kuhn fala sobre cientistas (Copérnico, Einstein, Pauli) que relataram sentimentos desesperadores em épocas de crises por conta de anomalias (Kuhn, 2012, p. 167). Mas isso não explica completamente a resistência; há algo mais.

A busca pelo saber envolve um apurado senso de ceticismo. Um resultado anômalo normalmente é atribuído a um erro de experimento ou de experimentador. Apenas depois de severos testes, com confirmações feitas por outros experimentos e experimentadores, é que se começa a duvidar da teoria. A própria descoberta do buraco negro supermassivo acima citada foi confirmada por observatórios

110 Disponível em: http://sciam.uol.com.br/buraco-negro-grande-demais-para-existir-edetectado-na-via-lactea. O link, consultado em dezembro de 2019, não está mais disponível. No seguinte link há um artigo relatando a mesma descoberta, publicada na revista Nature: https://www.fisicadiferencial.info/a-f\%C3\%ADsica-continua. 
independentes antes de se sugerir uma alteração na teoria. O ceticismo pode fazer com que cientistas relutem em aceitar novidades realmente promissoras. Alguns, de fato o fizeram: Priestley acreditou no flogisto até o fim de sua vida, mesmo tendo sido considerado um dos descobridores da substância que tornou a teoria flogística obsoleta (o oxigênio). O próprio Einstein duvidou da teoria quântica, também até o último de seus dias. Porém, apesar de um possível atraso que esses cientistas possam estar impondo ao próprio avanço da Ciência, esse mecanismo acaba servindo como freio para erros em potencial.

Existe na Ciência uma ideia que "paira no ar" de que o conhecimento pode e deve avançar, mas a pequenos e seguros passos. Nietzsche, expressando-se acerca da proposta ousada de Tales em identificar a água como origem de tudo, traz com sua poética marcante a seguinte ilustração (Os Pré-Socráticos, Col. Os Pensadores, 1996, pp. 55-6):

"E [é] notável a violência tirânica com que essa crença trata toda a empiria: exatamente em Tales se pode aprender como procedeu a filosofia, em todos os tempos, quando queria elevar-se a seu alvo magicamente atraente, transpondo as cercas da experiências. Sobre leves esteios, ela salta para diante: a esperança e o pressentimento põe asas em seus pés. Pesadamente, o entendimento calculador arqueja em seu encalço e busca esteios melhores para também alcançar aquele alvo sedutor, ao qual sua companheira mais divina já chegou. Dir-se-ia ver dois andarilhos diante de um regato selvagem, que corre rodopiando pedras; o primeiro, com pés ligeiros, salta por sobre ele, usando as pedras e apoiando-se nelas para lançar-se mais adiante, ainda que, atrás dele, afundem bruscamente nas profundezas. O outro, a todo instante, detém-se desamparado, precisa antes construir fundamentos que sustentem seu passo pesado e cauteloso; por vezes isso não dá resultado e, então, não há deus que possa auxiliá-lo a transpor o regato."

Esse último andarilho é claramente um cientista, cujo sentimento de desamparo e necessidade de construção de fundamentos como atitude de cautela contrasta com os saltos filosóficos. Lembremo-nos, por exemplo, dos saltos que deram Aristarco ao propor o heliocentrismo e Demócrito ao propor o atomismo; lembremo-nos em seguida que apenas após muitos séculos os cientistas estavam prontos para aceitar dar passos confiantes em direção a essas duas ideias até então fabulosas.

Esse acaba se revelando como um dos motivos que fazem com que não 
existam simples falseamentos na Ciência: qualquer possível falseamento, assim como o surgimento de qualquer nova hipótese que explique uma anomalia qualquer, tendem a ser sempre vistos com ceticismo, com prudência, com parcimônia. Sobre esse modo de agir da Ciência, disse Kuhn (2012, p. 65):

"A ciência normal, atividade na qual a maioria dos cientistas emprega inevitavelmente quase todo seu tempo, é baseada no pressuposto de que a comunidade científica sabe como é o mundo. Grande parte do sucesso do empreendimento deriva da disposição da comunidade para defender esse pressuposto - com custos consideráveis, se necessário. Por exemplo, a ciência normal com frequência suprime novidades fundamentais, porque estas subvertem necessariamente seus compromissos básicos."

Não podemos esperar que alguém simplesmente irá falsear a Relatividade, a Evolução ou o Big Bang. O mais provável é que as anomalias, que já devem estar entre nós, ainda que estejam sendo ignoradas, despercebidas, ou tendo suas resoluções postergadas, se acumulem através das próximas décadas, tornando-se cada vez mais evidente a todos os envolvidos na pesquisa que se trata de algo realmente digno de revisão. Até lá, qualquer incompatibilidade da teoria com a natureza, incompatibilidade essa percebida através da comparação proporcionada por observações empíricas, não será motivo para abandono da teoria anterior. Isso contrasta seriamente com o estereótipo propagado por divulgadores de que os cientistas substituem suas teorias devido ao falseamento das mesmas. Sobre isso, diz Kuhn (2012, p. 160) que "nenhum processo descoberto até agora pelo estudo histórico do desenvolvimento científico assemelha-se ao estereótipo metodológico da falsificação por meio da comparação direta com a natureza". O Critério de Popper fica, diante dessa análise, em posição realmente muito frágil, conforme já abordei com maiores detalhes no Capítulo I.

De acordo com a visão de Kuhn, cedo ou tarde, as anomalias tornar-se-ão insustentáveis. Os cientistas comuns, que em sua maioria dedicavam-se a aplicar um paradigma bem estabelecido, não tem mais a segurança necessária para continuar suas pesquisas. Há uma comoção, uma intensificação dos debates e começa a surgir uma profusão de novas teorias para explicar os fenômenos. Grupos se aliam em torno de cada teoria para defendê-la das críticas das demais. Está instalada a crise na Ciência, que resultará em uma Revolução e, finalmente, em uma mudança de paradigma. 
Antes de examinar a crise e suas consequências, é importante adiantar que, do ponto de vista científico, as crises são algo positivo sob muitos aspectos: é delas que surgem os grandes avanços, os grandes saltos conceituais em nosso entendimento, as grandes mudanças de visão de mundo. Isso não significa que devamos implementar uma crise que seja permanente: períodos de estabilidade, a chamada ciência normal, são necessários para se colher os frutos da crise precedente. Mas agora entra uma especulação que a mim é muito instigante: se essa colheita ocorrer de maneira rápida, se a ciência normal conseguir velozmente extrair do paradigma vigente todos os seus frutos e levá-lo até o limite de seus limites, então crises também podem ser produzidas mais rapidamente - o que levaria o progresso científico a ocorrer com maior rapidez. Quem, alinhado com o espírito de nosso tempo, iria se posicionar contra um avanço científico mais rápido? Pelo contrário, muitos desejamos saber qual será a nova descoberta, qual a novidade que irá revelar novos e impensados mistérios da Natureza, qual será o futuro do conhecimento humano.

Para comentar algo mais com relação a esse tema entusiasmante, reproduzo aqui as palavras do prof. Martins (1993, p. 18, [ ] meus):

"Sob o ponto de vista heurístico e metodológico, e não da realidade (ontologia) ou da utilidade explicativa, há certas concepções que são úteis ao progresso científico e outras que prejudicam ou inibem esse progresso. Por exemplo: o universo pode ser considerado como compreensível ou incompreensível. Não sabemos se ele de fato é compreensível ou não; mas supor que é compreensível estimula a pesquisa e a busca de causas e de leis; supor que não é, desestimula a pesquisa científica. Da mesma forma, poderíamos supor que as leis científicas atualmente aceitas são verdadeiras e finais ou que são falsas e temporárias. Não sabemos qual a verdade [nesse caso, acredito que sim, sabemos: nossas teorias atualmente aceitas não são nem verdadeiras, nem finais]. Mas é útil [mais do que útil: é o correto], sob o ponto de vista do progresso científico, supor que as leis atualmente aceitas são falsas ou imperfeitas e procurar outras leis ou exceções às leis conhecidas. Um exemplo mais restrito: pode-se supor que as chamadas 'partículas elementares' são de fato 'elementares' (isto é, sem partes, indecomponíveis) ou que é possível descobrir sua constituição. A primeira atitude é conservadora e limita a pesquisa àquilo que já é conhecido. $A$ segunda atitude é capaz de estimular a pesquisa do desconhecido e pode, portanto, levar mais facilmente ao progresso da ciência. Supor que nada existe no universo além do que já conhecemos, é uma crença que desestimula a pesquisa. Uma de suas formas é exatamente a negação do 
inobservável - e a negação do éter, em particular. Se supomos que existe o éter, abre-se um novo campo de indagações e de pesquisa; se supomos que, ao retirar tudo o que percebemos de um recipiente, lá não resta nada, não há o que investigar nesse local. Assim, como concepção diretriz para a pesquisa, é preferível supor a existência do éter do que negá-lo."

Se os professores e divulgadores adotassem postura semelhante, sempre propondo a possibilidade da existência de entidades mais além do conhecido, esse poderia ser um método tremendamente eficaz para se estimular o interesse dos jovens pela Ciência — ainda mais se for feito um convite direto do tipo: "Vocês também podem participar dessas investigações! Vocês também podem ir em busca do desconhecido! Talvez esteja entre vocês aquele(a) que irá fazer a nova grande descoberta!". Mas se, friamente, permanecemos negando a existência desses entes desconhecidos (lembrando sempre que inexistência é uma condição impossível de se comprovar empiricamente), poderemos estar perdendo, ou ao menos inibindo, sem saber, novos e originais pesquisadores que poderiam ser os próximos grandes contribuidores da Ciência. Existem, certamente, muitos fatores que incidem sobre a velocidade do progresso científico. Mas, de todos, provavelmente, essa maneira progressista de se abordar as entidades por serem descobertas é a mais imediatamente acessível e a de mais baixo custo. Talvez, essa simples atitude pudesse gerar algum efeito sobre a velocidade com que a ciência normal dá espaço a uma crise, e daí partiríamos com mais frequência, mas não permanentemente, para a próxima Revolução Científica.

\section{4 - Revoluções Científicas e Mudança de Paradigma}

De acordo com Kuhn, nem sempre a Ciência avança a pequenos passos. Isso geralmente se dá apenas no âmbito da Ciência normal, quando o paradigma em vigor não está ameaçado por graves anomalias. O quão grave será considerada uma anomalia depende de uma série de fatores. Normalmente, uma anomalia não é vista logo que surge. Algumas teorias são mais sensíveis a anomalias do que outras. Sobre isso, diz Kuhn (2012, p. 143): 
"Quanto maiores forem a precisão e o alcance de um paradigma, tanto mais sensível este será como indicador de anomalias e, consequentemente de uma ocasião para a mudança de paradigma. [...] Ao assegurar que o paradigma não será facilmente abandonado, a resistência garante que os cientistas não serão perturbados sem razão. Garante ainda que as anomalias que conduzem a uma mudança de paradigma afetarão profundamente os conhecimentos existentes."

É possível realizar vários comentários sobre essa citação. A precisão e o alcance de um paradigma podem ser interpretados, de acordo com a epistemologia de Popper, como o conteúdo empírico de uma teoria. Assim, teorias de mais alto conteúdo empírico são mais precisas e tem maior alcance, fazendo com que seja mais fácil de se notar qualquer desvio no comportamento esperado da Natureza. Isso sugere que teorias com maior conteúdo empírico também progridam mais rapidamente, uma vez que suas afirmações serão constantemente colocadas em cheque por novos dados empíricos que se tornam acessíveis. Isso explica em grande parte o porquê de a Física progredir, ao menos em certo sentido, mais rapidamente do que a Biologia: enquanto que as hipóteses dessa última estão confinadas essencialmente aos seres vivos, seus constituintes e seu ambiente circundante, a primeira tem literalmente o Universo inteiro como campo de investigação (além de fazer previsões matemáticas com uma precisão inalcançável por qualquer teoria biológica). Dessa maneira, teorias da Física são muito mais sensíveis e susceptíveis de falseamento, revisão, correção e substituição, se comparadas com teorias da Biologia.

Com relação à resistência natural que os cientistas sentem frente a novidades anômalas, temos que o ceticismo pode, e certamente fez em alguns casos, atrasar por algum tempo algum avanço iminente. Porém, ao mesmo tempo, trás consigo a vantagem de se evitar precipitações desnecessárias e garantir que as anomalias encontradas sejam realmente dignas de atenção.

No caso de uma anomalia se mostrar persistente, cada vez mais cientistas serão forçados a saírem da zona de conforto fornecido pelo já passado consenso paradigmático, para a seguir ingressar no mundo da criação de teorias. É neste momento, mais do que em qualquer outro, que percebe-se que as teorias não surgem dos dados empíricos, mas devem, sim, serem inventadas. Todos os cientistas que trabalham na área em crise dispõem dos mesmos dados empíricos para trabalhar (os 
dados que insistentemente recusaram-se a encaixar-se ao antigo paradigma). Porém, de forma alguma a teoria que explica esses dados é autoevidente. Teóricos, dotados de diversas perspectivas de ideais e de métodos, podem oferecer explicações completamente diferentes, absolutamente incompatíveis, todas com potencial para explicar o fenômeno em questão. De fato, tendo um conjunto de dados à disposição, a quantidade de explicações possíveis que harmonizem tais dados é virtualmente infinita (tal como é infinita a quantidade de funções que contêm uma quantidade finita e determinada de pontos em um plano cartesiano).

Aqui entra em jogo a complexa questão da escolha de teorias. Qual delas escolher? Como a história da Ciência pode nos ajudar a entender a forma como as teorias foram escolhidas ao longo do tempo? Vejamos.

Em geral, o principal erro cometido por divulgadores é transmitir a falsa impressão de que os cientistas estão completamente dispostos a abandonar teorias quando se deparam com os, assim chamados, falseamentos. Eles não estão. Esse é um ponto que já comentei anteriormente, mas que deve ser reforçado devido à frequência com que essa ideia errônea é divulgada. Vou retomar alguns dos conceitos normalmente esquecidos ou mal entendidos: se tomado em seu pleno rigor, o Critério de Falseabilidade faz com que todas as teorias já nasçam falseadas, pelo simples fato de serem incapazes de explicar todos os fenômenos que pretendem explicar. $E$ mesmo se desconsiderarmos esse fator de rigor, ainda resta o fato de que nenhuma teoria está apta a ser falseada completamente. Elas sempre são falseadas apenas pontualmente. Isso ocorre pois as teorias são sempre apenas parcialmente empíricas (ou seja: apenas alguns de seus enunciados são passíveis de teste e de falseamento), e também porque a quantidade de enunciados empíricos deriváveis de uma teoria qualquer é potencialmente infinita (tornando impossível o teste de todos eles) — isso é um incontornável fato lógico.

Os demais enunciados que compõe uma teoria são metafísicos, não passíveis de teste. É por isso que um falseamento permite que seja possível manter uma teoria, bastando apenas realizar pequenas modificações em seus enunciados, ou continuando a aceitar todos os enunciados que ainda não foram falseados como suficientes e satisfatórios. Como também já dito, é bastante comum o uso de hipóteses ad hoc para blindar teorias contra falseamentos. No Ensaio Introdutório d'A Estrutura, 
Ian Haking compara essa ideia popperiana com a proposta de Kuhn (Kuhn, 2012, p. 33):

"[...] Popper [...] convertera a refutação no cerne de sua filosofia. Kuhn esforçou-se especialmente em dizer que raramente existe algo como simples refutação. Nós temos a tendência de ver o que esperamos, mesmo quando a coisa não está lá. Amiúde leva muito tempo para que uma anomalia seja vista pelo que ela é: algo contrário à ordem estabelecida. Nem toda anomalia é levada a sério. [...] O reconhecimento de algo como sendo uma anomalia significante que deve ser explicada — mais do que uma discrepância que irá se resolver sozinha com o tempo - é, por sua vez, um evento histórico complexo, e não uma simples refutação."

Um exemplo histórico disso, comentado no mesmo texto, é o caso do movimento Browniano. Ele foi uma anomalia a princípio insignificante, algo que seria resolvido com o tempo, a ponto de não ser vista realmente como uma, apesar de se recusar a se encaixar em qualquer modelo mecânico conhecido até então. $E$ foi então que, justamente partindo dessa brecha, teve origem uma das corroborações mais contundentes da teoria atômica, quando Einstein explicou o fenômeno em dos artigos de seu "milagroso" ano de 1905. E acerca das crises, Kuhn ainda assevera (2012, p. 156, [ ] meus):

"O fracasso com um novo tipo de problema é muitas vezes decepcionante, mas nunca surpreendente. Em geral, nem os problemas nem os quebra-cabeças cedem ao primeiro ataque. Finalmente, esses exemplos [de crise] partilham outra característica que pode reforçar a importância do papel da crise: a solução para cada um deles foi antecipada, pelo menos parcialmente, em um período no qual a ciência correspondente não estava em crise. Tais antecipações foram ignoradas, precisamente por não haver crise."

O grande exemplo da antecipação do heliocentrismo por Aristarco de Samos torna difícil contestar essa afirmação de Kuhn. Que o sol se encontra no centro de nosso sistema solar, sendo orbitado pelos planetas, é considerado pela Ciência de hoje um conceito acima de qualquer dúvida. No entanto, muito se demorou para que tal conceito fosse aceito, tendo sido classificado pela maior parte dos sábios compreendidos entre Aristarco e Copérnico como algo absurdo. E então entra em cena a famosa frase: "Qual é o absurdo de hoje que será considerada a verdade de amanhã?". Quantas ideias, hoje consideradas "não científicas" ou "pseudocientíficas", 
farão parte de nossos próximos paradigmas firmemente aceitos no futuro?

Para completar, cientistas não podem simplesmente abandonar suas principais teorias apenas por terem sido parcialmente falseadas (e nem mesmo se fossem totalmente falseadas, caso fosse possível). Sobre isso, afirma Kuhn (2012, p. 101) que "abandonar o paradigma é deixar de praticar a ciência que ele define." Depois, completa dizendo que "tais deserções realmente ocorrem". E elas ocorrem justamente pela recusa de alguns dos envolvidos em acatar a ideia emergente.

É por isso que o abandono de uma teoria tem como requisito a pré-existência de uma substituta em potencial. Ainda sobre a antecipação de Aristarco, diz Kuhn (2012, p. 157):

"[...] não havia razões óbvias para levar as propostas de Aristarco a sério. Mesmo a versão mais elaborada de Copérnico não era nem mais simples nem mais acurada do que o sistema de Ptolomeu. As observações disponíveis, que serviam de testes, não forneciam base suficiente para uma escolha entre essas teorias. Em tais circunstâncias, um dos fatores que levou os astrônomos a Copérnico (e que não poderia tê-los conduzido a Aristarco) foi a crise característica que fora responsável pela inovação. A astronomia ptolomaica fracassara na resolução de seus problemas; chegara o momento de dar uma oportunidade a um competidor."

Dessa forma, não faz sentido afirmar que "Copérnico refutou Ptolomeu". Os astrônomos que foram gradualmente aceitando a teoria de Copérnico não o fizeram por esse ter "falseado" Ptolomeu. Em realidade, o modelo de Ptolomeu já nasceu falseado, pois nunca se encaixou perfeitamente às observações empíricas (assim como nenhuma de nossas teorias se encaixa - caso se encaixassem, o que estariam fazendo os cientistas em seus laboratórios?). Levando-se a sério o critério de Popper, o modelo ptolomaico nunca teria sido aceito, para começo de discussão. E, para piorar, o seu substituto (o modelo copernicano) igualmente já nasceu falseado: como afirma Kuhn, ele não era nem mais simples nem mais acurado do que o sistema de Ptolomeu. Ele não foi aceito por que os cientistas "honestamente assumiram que estavam errados com relação ao modelo geocêntrico, que fora falseado pelo heliocêntrico": em realidade, eles apenas estavam encurralados pela realidade — ou eles davam uma chance a um modelo novo, ou estariam condenados à insuficiência insuperável de um modelo que claramente já havia dado todos os seus frutos. 
Outro exemplo: a suposta refutação da Física de Aristóteles devido aos experimentos de Galileu. Diz o prof. Porto (2009, pp. 6-7):

"[...] não é correto afirmar, como bem salientou Paul Feyerabend, que a física de Aristóteles tenha sido abandonada em face de uma refutação experimental, apontada pelos adeptos da nova ciência, surgida do copernicanismo. A adoção vertiginosa da nova concepção de mundo se deveu antes à influência de elementos filosóficos, psicológicos e até mesmo estéticos, do que à necessidade de uma resposta a inconsistências irremediáveis do aristotelismo vigente à época. De fato, a vitória dos novos paradigmas sobre a ciência aristotélica não se obteve, desde o primeiro momento, através de um falseamento inquestionável do pensamento então vigente, mas através de uma reinterpretação dos elementos empíricos a partir de novos pressupostos. $O$ fato experimental de que uma pedra largada do alto de uma torre toca o solo em um ponto próximo à base dessa torre e não em um ponto afastado dela foi, durante algum tempo, utilizado pelos partidários do aristotelismo como prova da imobilidade da Terra. Galileu reinterpretou este fato empírico acrescentando à explicação do fenômeno um conceito de inércia dos corpos, que faria com que a pedra, após lançada, compartilhasse do movimento da torre, com a qual antes era solidária, de tal modo que esse movimento seria para ela imperceptível e assim, para ela, a torre se comportaria como se estivesse em repouso. Tínhamos, portanto, não a imposição de uma contradição insolúvel ao pensamento estabelecido e sim o confronto entre duas teorias alternativas."

Toda essa complexidade envolvendo a troca de paradigmas não é um caso isolado ou pouco representado na história da Ciência. Toda grande mudança passou por esse processo complexo e riquíssimo, que não pode ser reduzido a uma mera questão de que a teoria supostamente falseada foi abandonada em prol de uma que não fora.

Há ainda um outro aspecto que creio ser de fundamental importância para a compreensão da relação entre teorias novas e antigas: é comum que as novas teorias realizem sérias revisões não só no campo empírico, mas também no campo metafísico; os conceitos mais básicos e essenciais são totalmente reformulados, de forma que as duas teorias se tornam incomensuráveis. Esse último termo foi adotado por Kuhn e foi diversas vezes mal utilizado por outros autores ou mal entendidos pelo público e comentadores de sua obra, conforme alerta Laudan (1993, nota [2], [ ] meus): 
"Esse problema é muito sério. Por exemplo, alguns comentadores de Kuhn e Feyerabend [que também adotava o termo], certamente pouco familiarizados com o sentido técnico desses termos, entendem que teorias incomensuráveis são simplesmente aquelas que fazem diferentes asserções sobre o mundo, ou asserções entre as quais nenhuma clara escolha possa ser feita."

Essas noções ressaltadas por Laudan estão equivocadas e pode ser que ainda hoje, em 2019, novos equívocos nessa mesma direção estejam ocorrendo. De qualquer maneira, a interpretação que proponho aqui é a de que a incomensurabilidade é uma incompatibilidade metafísica entre teorias. Explico a seguir ${ }^{111}$.

Um exemplo claro disso é a substituição da gravitação newtoniana pela einsteiniana. Os conceitos metafísicos de espaço e tempo absolutos foram substituídos pelo de espaço-tempo, agora entendidos como uma única e mesma realidade, e uma realidade relativa. Ao considerarmos todas as demais modificações, tanto metafísicas quanto empíricas (a redefinição do conceito de massa e energia, o limite superior para a velocidade da luz, a gravidade não mais vista como uma força mas, sim, como uma distorção do espaço-tempo etc.), concluímos que a teoria de Einstein não é uma simples evolução com relação à teoria de Newton. Em realidade, elas são completamente incompatíveis. Dizer que a Relatividade se reduz à mecânica newtoniana para campos gravitacionais fracos e velocidades pequenas, é, no máximo, uma meia-verdade (ou seja: é uma mentira). Realmente, os valores numéricos se aproximam tanto quanto queiramos nas condições cotidianas, mas os significados essenciais, os conceitos que embasam esses valores, são tão diferentes que estão além de toda comparação. É isso o que significa a incomensurabilidade.

Refletindo na questão do porquê de teorias incomensuráveis tenderem aos mesmos valores numéricos, empiricamente testáveis e em condições limite, percebese que a incomensurabilidade é uma fator que faz referência àquela parte da teoria que é puramente metafísica. Como a nova teoria implica uma revisão total dos princípios metafísicos envolvidos, resulta que os novos princípios se tornarão

${ }^{111}$ Deixo um lembrete aqui de que assumo um realismo moderado, em que algo, por menor que seja, precisa ser preservado de teoria em teoria, ainda que seja difícil determinar o que. Muitos autores concordam com a importância de se assumir uma posição moderada, tal como podemos ver em El-Hani \& Bizzo (2002), Bagdonas \& Silva (2013) e Bagdonas, Zanetic \& Gurgel (2014). 
naturalmente incompatíveis com os antigos. É realmente notável que a parte empírica produza resultados similares quando certas condições são atendidas, mas se levarmos em conta que esses resultados, antigos e novos, são sempre aproximações (e nunca realmente iguais) e que a nova teoria costuma alcançar campos de aplicação no qual a teoria anterior falha completamente, a incomensurabilidade pode ser melhor entendida.

Nas palavras de Kuhn (2012, p. 66), "[...] uma nova teoria [...] nunca ou quase nunca é um mero incremento ao que já é conhecido". Mas se novas teorias não são simples acréscimo de conhecimento, isso é um forte motivo para aceitar que a Ciência não progride de maneira cumulativa e linear. Isso não significa que não há progresso, mas, sim, que esse mesmo progresso se dá de maneira muito mais complexa do que nossos livros e professores geralmente nos apresentam.

As Revoluções Científicas são realmente uma mudança radical no modo de se enxergar o mundo natural. Completa Kuhn (2012, p. 128):

"A assimilação de um novo tipo de fato exige mais do que um ajustamento aditivo da teoria. Até que tal ajustamento tenha sido completado - até que o cientista tenha aprendido a ver a natureza de um modo diferente — o novo fato não será considerado completamente científico."

É por isso que, independentemente do Critério de Popper, certos conhecimentos que poderiam ser encarados com maior seriedade e consideração são simplesmente descartados como metafísicos ou pseudocientíficos, quando em realidade o que ocorre é que eles simplesmente precisam de um paradigma que forneça a visão de mundo necessária para compreendê-los. É por isso que sugiro a busca por meios menos truculentos de se lidar com o que chamamos hoje de pseudociência. Uma ou outra pseudociência poderá revelar-se no futuro estar correta, apesar de ser atualmente totalmente desconsiderada. Da mesma maneira, teorias atuais, aceitas como plenamente científicas poderiam, em outros tempos, ser consideradas como metafísicas ou pseudocientíficas.

Existem casos realmente insólitos quando analisamos as grandes mudanças que ocorreram na história da Ciência. O caso das teorias da luz é um deles. No debate onda versus partícula, Newton se sobressaiu contra Huygens. A reviravolta foi impactante, quando Young e Fresnel demonstraram a natureza ondulatória da luz. Essa demonstração foi tão contundente e inequívoca que parecia completamente 
impossível um retorno da teoria corpuscular. Mas foi justamente o que aconteceu quando Einstein propôs o fóton como explicação do efeito fotoelétrico, resultando no que considero o maior plot twist da história da Física! A concepção adotada a seguir foi a da dualidade onda-partícula, completamente inimaginável antes da contribuição decisiva de Einstein. Isso nos leva a questionar: quantos conceitos mais, dentre os que foram abandonados, não poderão retornar no futuro, com uma nova interpretação? Seria por acaso ridícula a ideia de que o calórico ou o éter possam, um dia, voltar a fazer parte do arsenal de conceitos científicos considerados válidos? Pensemos na Matéria Escura: uma forma de matéria imponderável que preenche todo o espaço. Ora, não são essas as duas das principais características que eram atribuídas ao éter? E se a Matéria Escura não for simplesmente um retorno disfarçado do éter ${ }^{112}$ ? Cientistas do final do século XIX acreditaram ter enterrado o conceito de luz como partícula. Muitos se sentiram realmente defraudados com os conceitos radicais da Física nascente.

Isso tudo tem consequências normalmente subestimadas: absolutamente nada impede que os nossos conceitos atuais sejam substituídos por outros novos e totalmente incomensuráveis. Mesmo com respeito aos conceitos considerados os mais fundamentais, como os átomos, a força, os campos, a massa, a energia, a entropia, a evolução, dentre muitos outros, não podemos assegurar que não serão abandonados no futuro. A Ciência desenvolvida ao final do século XX seria totalmente incompreensível para os cientistas do século XIX. Como será a nossa Ciência daqui um ou dois séculos? Seria muito mais responsável por parte dos divulgadores assumirem, de uma vez por todas, que todos os resultados da Ciência são parciais e temporários. Não importa o quão bem estabelecida uma teoria está; o tempo irá, por fim, substitui-la. E isso leva a um outro ponto crucial quando nos referimos à mudança científica: a influência do "espírito do tempo", o chamado zeitgeist.

Ainda existem estudiosos da Ciência que afirmam estar ela rumando à Verdade. Sagan afirma e torna a afirmar no clássico O Mundo Assombrado Pelos Demônios (livro analisado no próximo capítulo) que a Ciência ruma assintoticamente à realidade. Essa ideia está associada à visão de Ciência que acabou de ser criticada: a da cumulatividade e linearidade do desenvolvimento científico. É contra essa visão

112 Sobre o possível retorno do éter, recomendo o excelente artigo do prof. Martins (1993): Em Busca do Nada: Considerações Sobre os Argumentos a Favor do Vácuo ou do Éter. Ver referências. 
que Kuhn afirma que a Ciência não avança em direção à Verdade, mas em direção ao que queremos saber. É claro que para o Realismo moderado (posição que defendo), um avanço científico que trás mais e melhores explicações, com previsões acertadas e incremento de precisão, não pode significar um afastamento da Verdade (entendida aqui simplesmente como o conhecimento da estrutura da Natureza). Porém, não é possível comprovar que o avanço de fato nos aproximou da Verdade. O que podemos dizer com segurança é que a nova teoria nos deu o conhecimento que buscávamos, e só. A fala de Kuhn por vezes foi interpretada como pessimista ou relativista, embora a vejo tão somente como uma constatação humildemente realista.

Nosso tempo nesse mundo é limitado. Ao mesmo tempo, as possibilidades que o Universo nos oferece são ilimitadas. Só nos resta uma opção: escolher o que queremos saber, escolher o que é prioritário, para só então nos lançarmos à busca por respostas.

$\mathrm{Na}$ escolha entre teorias concorrentes, ficamos diante de uma série de fatores difíceis de avaliar. Não se trata simplesmente de escolher "a melhor teoria", a "mais simples" ou "a que se adequa melhor aos fatos" pois, além de não ser fácil definir "melhor" ou "mais simples", ocorre que os fatores acima citados são independentes entre si. Isso quer dizer que uma teoria pode explicar melhor o fenômeno, mas ser menos abrangente do que outra que não explique tão satisfatoriamente. Podemos também ter uma teoria que explique bem o fenômeno, mas não se adeque tão bem a explicar os demais fenômenos já aceitos e explicados por teorias anteriores. Um exemplo dessa última, inclusive citada por Kuhn, foi a teoria da combustão baseada em oxigênio suplantando a teoria do flogisto. Essa última, há muito aceita e utilizada como paradigma pelos químicos da época, dava conta de explicar uma série de fenômenos que a nova teoria não era capaz. Isso gerou um sério dilema entre os químicos que se viram diante da escolha entre ambas as teorias: abandonar a teoria do flogisto, e com isso abandonar todas as explicações satisfatórias que ela fornecia, ou aceitar a nova teoria, forçando-os a buscar explicações novas para fenômenos que já eram bem compreendidos sob o olhar da teoria antiga. Laudan (1993) sintetiza essa visão de Kuhn, também compartilhada por outros filósofos da Ciência do século XX, que "um conjunto posterior de suposições diretivas [um novo paradigma] raramente acomoda todos os êxitos explicativos de seus predecessores. No processo de substituição, há tanto perdas como ganhos". 
Em uma passagem especialmente lúcida, lembrada por Kuhn n'A Revolução, Charles Darwin afirma n'A Origem das Espécies (2009, p. 414): "[...] deposito a minha confiança no futuro, nos jovens naturalistas em ascensão, que poderão analisar os dois lados da questão [evolução vs criação] com imparcialidade".

Essa influência da juventude na mudança científica reflete tanto o zeitgeist (pois cada geração cresce em um ambiente cultural e intelectual mais ou menos diverso da geração anterior) quanto a resistência dos antigos em deixar uma ideia que já foi aceita. Embora possa-se questionar se realmente os jovens "analisam os dois lados da questão com imparcialidade", esse ponto de vista ajuda a entender o porquê de os "pais" da Mecânica Quântica, de Einstein a Dirac, terem dado suas primeiras contribuições decisivas ainda em sua juventude (antes dos trinta anos de idade). Nenhuma teoria nova, especialmente as que questionam as bases fundamentais as bases metafísicas - das teorias anteriores, será aceita sem grande resistência. De acordo com Kuhn (2012, p. 175), a conversão de novos adeptos se dá aos poucos, e o papel da juventude também é ressaltado.

É preciso que o divulgador e o professor encarem de frente a questão; sem idealizações, mas como a história da Ciência, em suas diversas interpretações, indica ser o modo como as coisas ocorrem. Mudanças são sempre difíceis, em qualquer área que seja, e serão tão mais difíceis quanto mais radicais forem as suas propostas. Cientistas são humanos que devotam suas vidas à causa do saber. Mas pode ser que o amor por seu objeto de estudo - as teorias às quais dedicou toda uma carreira ultrapasse sua boa vontade em considerar uma ideia contrária que as anule. Cientistas tendem a ter "teorias de estimação", e estão dispostos a lutar para defendêlas contra ataques externos. Ensinar Ciência sem levar esse aspecto em consideração é distorcer a realidade. Devemos promover a Ciência, visando conquistar novos entusiastas, a partir do que ela é e não a partir de uma estéril e vazia caricatura.

\section{5 - Progresso Científico versus Progresso Tecnológico ${ }^{113}$}

\footnotetext{
${ }^{113}$ Esta é uma seção mais "ensaística" e menos referenciada. Os leitores mais interessados em referências bibliográficas podem, sem prejuízos, pular para a próxima parte.
} 
É comum a ideia de que o avanço tecnológico é fruto do avanço científico. Inclusive, esse é um dos argumentos mais utilizados em prol da pesquisa científica: a Ciência seria o grande motor que impulsiona a tecnologia. Sem querer gerar polêmica, parece-me que esse argumento é superestimado. Segue minha ponderação.

Quando pensamos nas grandes invenções do mundo antigo, e até da Idade Média, logo nos vem em mente os navios, os equipamentos de batalha, a agricultura e as enormes construções, apenas para citar alguns. Imaginemos, por exemplo, os aquedutos romanos, o Coliseu e as catedrais góticas medievais. Lembremo-nos que foi nesse mesmo mundo medieval das catedrais, tachado injustamente de "Idade das Trevas", que foram feitas descobertas cruciais, como a do aumento de produtividade agrícola através da rotatividade de gêneros cultivados. Quanto de Ciência, no sentido moderno, esses povos conheciam? Bem pouca, sabemos. Mas como foi possível construir, com tão pouca Ciência, os aquedutos romanos e as catedrais medievais? Tudo o que eles possuíam podia se resumir a aplicações de geometria, a ferramentas rudimentares e conhecimentos puramente tácitos. Sem Leis de Newton. Sem teorias de estática, de dinâmica ou de química dos materiais. Como foi possível desenvolver técnicas de melhoria de cultivo sem possuir nem mesmo uma boa teoria biológica de botânica? Houve também, desde muito antes, o desenvolvimento da seleção e melhoramento de espécies de animais e vegetais domesticados. Melhorias técnicas de metalurgia possibilitaram a construção de equipamentos militares e de ferramentas para os mais diversos trabalhos da época. Tudo isso com praticamente nenhum conhecimento teórico (novamente, no sentido moderno) consolidado. E a lista poderia facilmente ser grandemente estendida.

O ponto é que esses avanços prescindiram da Ciência para acontecer. Os engenheiros daquelas épocas eram muito mais técnicos e práticos dos que o são os engenheiros de hoje em dia, que precisam, necessária e obrigatoriamente, receber um profundo treinamento em teorias da Física, da Química e até da Biologia para poderem atuar. Os engenheiros de antes, do campo e da cidade, trabalhavam com o acúmulo de conhecimento tácito, com experiências de tentativa e erro registradas e transmitidas através das gerações. Eles sabiam que uma ou outra determinada estrutura deveria parar em pé baseando-se, em parte, na geometria. Digo em parte porque a geometria não inovou significativamente desde os tempos da Grécia antiga 
até, ao menos, o Renascimento (pode-se dizer que a primeira grande novidade da geometria depois de Euclides foi a invenção da geometria analítica realizada por Descartes). As técnicas de construção, por sua vez, avançaram muito durante aqueles séculos. Isso sugere que a maior parcela do conhecimento necessário para tal avanço deve ter tido origem no conhecimento técnico, prático, acumulado ao longo dos séculos e transmitido sistematicamente de mestres a aprendizes, e não em avanços teóricos.

Vemos que, sob vários aspectos, essas pessoas dedicadas ao avanço tecnológico pouco tinham a ver com os engenheiros de hoje. Estavam mais para técnicos, que possuem relativamente menos conhecimento teórico, mas se especializam nas habilidades práticas de sua atividade. É por isso que Comte classificou os engenheiros como estando situados a meio caminho entre os Cientistas e os Técnicos (ver segunda lição de seu Curso de Filosofia Positiva). Os primeiros buscam descrições teóricas detalhadas dos fenômenos da natureza. Os últimos, buscam melhorar o conhecimento concernente ao fazer e ao produzir, tendo foco maior em atingir eficácia do que em entender a fundo o fenômeno em questão. São pessoas práticas por natureza, que costumam estar mais preocupadas em saber como um aparelho funciona do que em saber o porquê de ele funcionar. Os engenheiros modernos recebem uma formação que costuma juntar o melhor dos dois mundos: recebem uma forte base teórica do conhecimento científico disponível, ao mesmo tempo em que aprendem as mais modernas aplicações técnicas desses mesmos conhecimentos.

O engenheiro aprende Ciência tal como o cientista, mas a lógica e o perfil do engenheiro são diferentes: ele está ocupado com a praticidade, com a utilidade e com a aplicação do saber. Assim, o engenheiro faz a ponte entre o cientista e o técnico, ao mesmo tempo em que livra esse último de ter que aprender tanta teoria, podendo o técnico então tornar-se um perito na parte mais prática do serviço: manejar ferramentas e maquinário, programar algoritmos, fazer a manutenção de dispositivos etc. O cientista, o engenheiro e o técnico, dessa forma, são aliados e tornaram-se todos essenciais para os grandes empreendimentos de avanço científico das últimas décadas ${ }^{114}$ : das sondas que exploram o nosso sistema solar, passando pelo projeto

\footnotetext{
${ }^{114} \mathrm{~A}$ relação existente entre cientista, engenheiro e técnico é similar à que existe, na música clássica, entre o compositor, o regente e os músicos da orquestra: todos são necessários e complementam suas funções para gerar um resultado final maior do que a soma das partes.
} 
Genoma e chegando até o famoso LHC.

Ainda assim, poderíamos nos questionar se o avanço tecnológico realmente se deu tendo o avanço científico como motor, ou se foi justamente o contrário: avanços tecnológicos possibilitam avanços científicos, uma vez que os mais avançados conhecimentos empíricos são obtidos por meio de instrumentos com tecnologia cada vez mais potente. Também é possível especular o que teria ocorrido com os avanços tecnológicos se o conhecimento científico não tivesse crescido na mesma proporção (ou se simplesmente a nossa civilização tivesse se desenvolvido de outra forma, sem interesse nos assuntos mais abstratos e próprios da Ciência, concentrando seus esforços unicamente nos avanços tecnológicos).

Essa especulação tem uma boa justificativa: há um argumento utilizado com certa frequência contra a pesquisa científica de base. Esse argumento baseia-se na ideia de que os investimentos em pesquisas que não dão retorno prático imediato são inúteis. É compreensível que muitos pensem assim. Afinal, a pesquisa de base é feita sobretudo com dinheiro público. E, a julgar pelos títulos de grande parte dos trabalhos científicos, altamente específicos e aparentemente sem conexão com "coisas importantes", a impressão deixada é que os cientistas não estão realmente fazendo valer o que neles é investido. Os programas espaciais são, talvez, um dos que mais chamam a atenção nesse sentido. Por terem grande divulgação em veículos de mídia, o público tem conhecimento deles de maneira mais direta. A missão JUNO, destinada a investigar Júpiter, custou 1,1 bilhão de dólares. "Para que enviar uma sonda para outro planeta, enquanto o nosso próprio está cheio de problemas?", clama o senso comum.

O que se ignora em casos como esses são os avanços tecnológicos resultantes desse tipo de missão. Não que os dados coletados pela JUNO sirvam de fato para melhorar alguma tecnologia terrestre. Aliás, é bem difícil (embora não impossível) que qualquer informação sobre a atmosfera de outro planeta seja útil para se aprimorar uma tecnologia qualquer. Mas não precisa mesmo ser. $\mathrm{O}$ avanço tecnológico que ocorreu com essa missão não veio como resultado dela, mas como requisito. $\mathrm{A}$ tecnologia não melhora a partir de avanços científicos, mas antes essas melhorias são necessárias para que a investigação científica torne-se possível.

Engenheiros dedicam-se a melhorar a tecnologia quando se tem em mente um propósito bem definido. A Ciência provê esse propósito: ela exige microscópios e 
telescópios cada vez mais potentes, temperaturas e pressões cada vez mais extremas, campos eletromagnéticos cada vez mais intensos, substâncias cada vez mais puras, e tudo o mais que as teorias requerem para que possam ser empiricamente testadas. Os engenheiros envolvidos nesses testes tratam então de desenvolver tecnologias originais para cumprir com as exigências dos teóricos. É verdade que muitos cientistas elaboraram seus próprios aparatos experimentais, como o experimento que Fizeau inventou para medir a velocidade da luz, mas esses aparatos são arranjos de dispositivos que já devem existir para que a elaboração seja factível. Por exemplo, o experimento de Fizeau exigia, dentre outros dispositivos, um espelho semitransparente. Caso esses dispositivos não existam, eles precisarão ser inventados. Aí entra em jogo ou um engenheiro ou o próprio cientista atuando como um, a fim de melhorar a tecnologia existente para que cumpra com o seu propósito experimental. Independentemente do resultado do experimento, se corroborará ou falseará a teoria, o saldo final é um avanço tecnológico que agora está disponível para as mais diversas aplicações práticas e industriais.

Galileu, ao melhorar o telescópio holandês, e Newton ao criar o telescópio refletor, não agiram propriamente como cientistas em sentido estrito, mas antes como engenheiros. Eles não estavam inventando ou testando teorias, mas apenas encontrando formas de combinar, engenhosamente, lentes e espelhos afim de obter resultados específicos previstos pelas teorias que já possuíam, ou resultados que ao menos não eram por elas negados. Assim, para atender a necessidades científicas, a tecnologia precisa evoluir; em um segundo momento, ela estará disponível em computadores, celulares, aviões, hospitais, alimentação e em todo lugar que possamos imaginar. A Ciência, portanto, fornece um dos mais promissores incentivos ao avanço tecnológico. É claro que, novamente, as teorias científicas jogam o papel mais importante: sem elas, quem saberia qual é o avanço tecnológico necessário para atender aos testes experimentais? Afinal, o avanço tecnológico pressupõe o experimento ao qual se destina, e esse último pressupõe uma teoria que o justifique.

Podemos concluir que a Ciência e a tecnologia avançam juntas, mas com uma relação um pouco diferente da imaginada pelo senso comum. Enquanto esse afirma que as descobertas científicas geram avanços tecnológicos, a realidade parece mostrar algo diferente. Podemos assumir que o papel da Ciência, ao criar teorias, é fornecer a motivação para o avanço tecnológico, e é, em realidade, esse último que 
possibilita os testes que decisivamente irão decidir pelo avanço da Ciência. Mas, na ausência desse tipo de motivação, sempre existiria a motivação prática: a tecnologia deveria avançar em prol de uma melhor qualidade de vida, de um aumento de produtividade artesanal e industrial, dentre tantas outras motivações possíveis. Talvez a tecnologia pudesse continuar evoluindo indefinidamente por um caminho independente da Ciência (tal como ocorreu, grosso modo, ao longo de toda a história anterior ao surgimento da Ciência moderna). Poderíamos ter uma tecnologia muito diferente, baseada em princípios totalmente diversos, não fossem os avanços científicos para dar interpretações aos fenômenos envolvidos. Esse último ponto é importante: as teorias científicas interpretam o mundo. Elas não alteram ou controlam o mundo. Isso tem sérias implicações na visão geral que temos de Ciência.

O primeiro a se considerar é que tomar um possível avanço tecnológico como principal motivo para investimentos em Ciência é, considero eu, equivocado. A tecnologia poderia ter se desenvolvido sem a Ciência, ainda que pudesse ter ido em outra direção. Além disso a Ciência deveria ser considerada com um bem e um fim em si mesma: a satisfação do saber supera a do progresso material, ao ponto de que muitos cientistas colocaram suas vidas e seus trabalhos acima de qualquer valor financeiro ou de fama. Dizer que devemos investir em Ciência para que a tecnologia avance é mais fazer uma apologia da engenharia, comumente vista como uma aplicação da Ciência, do que da Ciência pura (ou "dura"), que denominamos de Ciência de base e que não tem obrigação alguma de fornecer aplicações práticas imediatas.

E em segundo lugar, mas não menos importante, é a falsa ideia de que o sucesso do funcionamento de uma tecnologia qualquer é a prova de que nossas teorias científicas são verdadeiras. Não vou voltar ao ponto de que teorias nunca podem ser "provadas verdadeiras"; creio já ter escrito o suficiente sobre isso até o momento. Mas é preciso levar em conta que qualquer tecnologia, especialmente as mais avançadas, é muito mais complexa do que qualquer teoria individual que foi utilizada para a sua confecção. Um produto tecnológico é, na verdade, um amálgama mais ou menos coeso de um grande número de aplicações de teorias que, a princípio, são independentes entre si. Um computador é explicado por uma teoria de polímeros que permitiu a fabricação dos plásticos envolvidos, por uma teoria eletromagnética que, por exemplo, descreve as correntes elétricas e a gravação de dados em discos 
rígidos, pela teoria quântica que explica o funcionamento dos inúmeros transistores utilizados como componentes, por uma teoria da computação (nesse caso, não pertencente ao campo das Ciências Empíricas) que governa a lógica de funcionamento dos algoritmos, e tantas outras. Não há uma teoria unificadora que descreva o computador. $\mathrm{E}$ todas as teorias científicas envolvidas estão sujeitas a mudanças no futuro. E essas mudanças podem ser radicais, fornecendo interpretações completamente diferentes para os mesmos fenômenos. Se alguma mudança ocorrer em qualquer uma das teorias envolvidas, ou se qualquer uma delas for completamente substituída por outra que Ihe seja incomensurável, não devemos esperar, como é óbvio, que a tecnologia pare de funcionar. Ela continuará funcionando, pois é independente das teorias que a descrevem.

As teorias forneceram aos engenheiros-inventores guias para seus projetos e previsões. Mas uma teoria dessas é sempre parcial e temporária, e é sempre uma dentre as muitas possíveis interpretações do mundo. Um aparelho funcionar baseando-se em uma teoria não "prova" a "verdade" da teoria, mas apenas indica que a descrição que fornece é, de alguma maneira, útil a nós ${ }^{115}$. Mas o dispositivo tecnológico sempre estará sujeito a ter seu funcionamento reinterpretado, na medida que qualquer uma de suas teorias-guia forem revisadas ou substituídas. Como exemplo, temos o fenômeno da fluorescência e de uma de suas principais aplicações tecnológicas: a lâmpada fluorescente. Tanto o fenômeno quanto a lâmpada foram descobertos e estudados ainda no século XIX. Nikola Tesla, a quem a invenção da lâmpada fluorescente é atribuída, fez experimentos com bulbos fluorescentes já na década de 1890 (a lâmpada obteve viabilidade comercial em 1938). As explicações teóricas da época eram absolutamente incompatíveis com a ainda não existente Teoria Quântica, sendo que essa última é a grande responsável pela compreensão que hoje temos do fenômeno da fluorescência. As explicações que permitiram a criação da lâmpada na década de 1890 são facilmente classificadas como "erradas" quando comparadas com a nossa compreensão atual; no entanto, a lâmpada funcionava. E continuou funcionando quando a teoria mudou. Vemos então que não se sustenta o argumento de que a tecnologia atual comprova a veracidade de nossas

\footnotetext{
115 Parece que estou caindo aqui no puro instrumentalismo, mas não é assim. Sim, o fato de uma teoria funcionar para determinado fim não prova que é verdadeira. Mas, como um realista moderado, eu creio que há nela algo de real, algo de verdade, ainda que não disponhamos de "provas" maiores do que argumentos a priori.
} 
teorias.

Termino a seção fazendo um resumo dos principais pontos abordados, lembrando que o intento maior é fornecer alternativas aos divulgadores e professores para quando estiverem ensinando Ciência aos seus respectivos públicos:

(I) O progresso tecnológico e o científico possuem alguma interdependência, mas o estudo histórico parece sugerir que a Ciência depende mais da tecnologia do que o contrário.

(II) A Ciência deveria ser incentivada e apoiada por seus próprios méritos, sem a necessidade de apelo aos possíveis avanços tecnológicos que venha a dar origem.

(III) Como consequência de (II), é importante salientar, durante o ensino, se estamos falando de Ciência pura ou se estamos falando de suas aplicações tecnológicas na forma de engenharia. O objetivo disso é incentivar o gosto pela Ciência pelo que ela é em essência, de forma que o aluno possa saber se está realmente interessado nela ou se o está, em realidade, em engenharia.

Por fim, (IV) aplicações tecnológicas não podem ser utilizadas como critério de veracidade de teorias, a não ser, talvez, em uma visão instrumentalista radical, da qual muitos, incluindo a mim, discordamos. 


\section{CAPÍTULO III - ENSINO E DIVULGAÇÃO CIENTÍFICA}

Após a pregressa revisão geral dos elementos constitutivos da Ciência e de sua dinâmica, assim como dos equívocos mais comuns que, infelizmente, ainda insistem em se perpetuar, estamos em um momento oportuno para olhar mais de perto a questão do ensino e da divulgação científica. Há um esforço acadêmico incessante, não só no Brasil ${ }^{116}$ mas também ao redor do mundo, para se melhorar e selecionar os métodos, os meios e os conteúdos do ensino. Esse esforço, porém, demonstra estar um tanto longe de atingir a realidade de quem mais necessita dessas melhorias: os jovens estudantes do Ensino Básico e o público em geral que possua algum interesse em aprender Ciência. Aliás, como fazer com que mais pessoas se interessem pela Ciência é, ela mesma, uma questão fundamental de investigação e de dedicação por parte de um grande número de pesquisadores da área.

Afirma Fourez (2003) e confirmam Bagdonas, Zanetic e Gurgel (2014) que o ensino de Ciências vive em crise. É difícil discordar dessa afirmação. Os problemas sociais, incluindo a educação em geral e a educação científica em particular, parecem insolúveis, ainda que um gigantesco esforço a nível global seja investido em pesquisa e trabalho árduo para se tentar resolver tais problemas. Contudo, essa afirmação faz com que eu me questione: porventura houve um tempo em que a educação científica foi realmente boa? A resposta concreta demandaria uma intensa pesquisa histórica a respeito, mas acho bem pouco provável que ela seja "sim, houve". A situação atual é realmente bem ruim, mas o fato é que os recursos disponíveis para que uma mudança se desenvolva são mais numerosos do que nunca.

Há uma discussão em andamento, ainda sem um consenso nacional, em se diferenciar as maneiras de se divulgar Ciência (Langui \& Nardi, 2009, p. 1). O presente trabalho não visa entrar nessa discussão. Tomarei dos autores apenas suas definições, ainda provisórias (ibidem, pp. 2-3), de educação formal (quando estiver me referindo ao ensino de Ciências em ambiente escolar/universitário) e educação não formal (no qual se encaixam os materiais de divulgação que analisarei - livros e canais do YouTube).

\footnotetext{
${ }^{116}$ Vemos em trabalhos como o de Salém e Kawamura (1996) que, no Brasil, tal esforço acadêmico vem sistematicamente ocorrendo ao menos desde a década de 70 .
} 
Tradicionalmente, reconhece-se que o ensino e a divulgação científica ocorrem através da escola, de palestras, de revistas, de livros e de museus científicos. O posterior surgimento da televisão possibilitou também a criação de canais especializados em divulgação. Alguns canais abertos da televisão possuem ao menos uma atração regular voltada à divulgação científica. Todos esses meios, embora pareçam numerosos, ainda são muito falhos em quantidade e em qualidade. É claro que é melhor do que nada, mas não devemos nos surpreender quando o nível de "letramento científico" (termo utilizado pela BNCC) da população é praticamente nulo ${ }^{117}$. As condições de ensino na escola são aquelas velhas e limitadas já bem conhecidas, especialmente pelos professores em atuação. As palestras, revistas, livros e museus continuam, em geral, caros, com pouca ou nenhuma divulgação midiática, e, consequentemente, pouco procurados. Tem sido, aparentemente desde sempre, árdua e penosa a tarefa de implementar uma cultura de saber em nosso país. O hábito de leitura regular e de qualidade continua sendo muito raro e, certamente, os canais e atrações de divulgação científica estão entre os de menor audiência relativa. Em meio a esse cenário, ao longo das últimas duas décadas, e principalmente a partir da década de 2010, ergueu-se uma alternativa a isso tudo, mais acessível e com maior alcance do que jamais presenciamos: a internet.

Vou dar meu exemplo pessoal: sou professor em uma escola localizada em Heliópolis, a maior comunidade carente da cidade de São Paulo. Aqui, é quase impossível encontrar um aluno que não disponha de um smartphone (até o momento, após sete anos de trabalho e tendo passado por mais de mil alunos, não me recordo de um único que não tivesse). Muitos possuem conexão própria com a internet, mas os que não dispõe podem acessar o Wi-Fi gratuito disponibilizado pela prefeitura. A escola em que trabalho, especificamente falando, conta com vários laboratórios com computadores e acesso à internet, além de uma biblioteca com bom acervo de livros e revistas científicas e ainda mais computadores conectados à web. Há uma grande biblioteca pública vizinha, no CEU Heliópolis, que também conta com um bom acervo de livros e periódicos, além de acesso à internet via computadores. Na prática, as bibliotecas continuam não estando entre os ambientes mais populares,

117 Em 2018, nenhum aluno brasileiro, dentre os quase onze mil avaliados, atingiu o nível máximo (nível 6) em Ciências no exame internacional do Programa Internacional de Avaliação de Estudantes (PISA). Mais da metade dos alunos encontram-se apenas no nível 1. Ver mais em http://portal.inep.gov.br/web/guest/pisa. 
permanecendo vazias na maior parte do tempo. Entretanto, não podemos mais dizer que o material para a obtenção do conhecimento não está mais acessível: ele está se as pessoas o buscam ou não, é outra história. Não é exagero afirmar que, hoje, mesmo pessoas com baixo poder econômico têm acesso livre a uma quantidade de informação e conhecimento esmagadoramente maior do que os mais ricos tinham há um século, ou mesmo há meio século.

Muito já foi dito sobre essa nova avalanche de informação que nos está disponível, e sobre a grande dificuldade de discernir o que serve do que não serve (ver, por exemplo, a pesquisa bastante atualizada realizada no já citado artigo de Massarani, Leal \& Waltz [2020]). A anticiência e a pseudociência encontraram um terreno vasto e fértil para se propagarem com praticamente nenhuma restrição. $A$ divulgação científica, majoritariamente de viés cientificista, também teve o seu espaço e tem muita força no Brasil, conforme analisarei em breve. Apesar do notável esforço de muitos desses divulgadores, há ainda em seus discursos a reprodução de muitas das noções equivocadas que abordei até aqui.

No presente capítulo, pretendo tecer alguns comentários sobre como a Natureza da Ciência é ensinada e divulgada em dois dos principais meios disponíveis no Brasil - livros e internet. O intuito não é, de forma alguma, atacar ou ofender divulgadores, mas apenas contrapor, com base em argumentação racional, algumas das concepções que, junto com toda uma geração de pesquisadores, defendemos merecerem revisão. Com relação aos comentários sobre a BNCC e livros didáticos, a análise será breve, uma vez que essa tarefa já foi empreendida por outros. Pretendo utilizar mais espaço com a análise de livros clássicos de divulgação científica estrangeiros (autores como Dawkins, Sagan e Hawking) e também brasileiros (Marcelo Gleiser e os mais recentes "Pirula" e Reinaldo José Lopes). Termino com a análise de canais brasileiros de divulgação, comentando alguns vídeos no que diz respeito a alegações pertinentes ao tema desta dissertação.

\section{1 - Comentário sobre a BNCC e sobre os livros didáticos}


Como sabemos, o princípio norteador da BNCC é ser abrangente e flexível o suficiente para abarcar diferentes métodos e concepções de ensino. Mas, dentro dessa abrangência, alguns fatores recebem mais atenção do que outros. O principal fator ao qual me dediquei nesse trabalho se refere à Natureza da Ciência. Nesse aspecto, a BNCC definitivamente não despende muita atenção.

Com relação a uma visão equilibrada de Ciência, encontramos a seguinte frase (BNCC, p. 556): "Se por um lado é fundamental avaliar os limites da ciência, por outro é igualmente importante conhecer seu imenso potencial". Essa "avaliação de limites" é justamente o ponto que considero ser onde mais o ensino e a divulgação têm falhado (no que se refere especificamente à questão da Natureza da Ciência). O "imenso potencial" da Ciência dificilmente é colocado em dúvida por uma pessoa de nosso tempo. Mas o conhecimento dos limites da Ciência parece ser muito mais difícil de ser incorporado ao ensino em geral. O trato dos limites da Ciência é um assunto próprio da Filosofia, especificamente da epistemologia. Normalmente, os conteúdos ensinados em um ensino padrão são os das teorias, daí seguindo-se a exercícios de aplicação. Isso se repete, inclusive, nos cursos de formação de professores (assunto amplamente discutido por Gil-Pérez et. al., 2001, embora eu pudesse somar a isso a minha própria experiência durante a graduação). Para completar, ainda há um disseminado desprestígio da Filosofia por parte da visão cientificista, o que tende a afastar o interesse dos estudantes pela epistemologia. As questões mais fundamentais da Teoria do Conhecimento ("O que podemos saber?", "Como podemos saber?", "Qual a validade do que sabemos?", "Como o saber aumenta?"), são, como boa parte das perguntas filosóficas, pouco feitas em aulas de Ciência.

Honestamente, nunca havia me perguntado sobre isso antes de ter meu primeiro contato com o tema em uma disciplina filosófica da graduação com o respeitável prof. João Zanetic. Esses simples, porém profundos, questionamentos levaram-me a refletir sobre todo o conteúdo teórico que aprendia nas disciplinas de Física. Logo percebi a importância do assunto e que estudantes de Ciência em geral teriam muito a ganhar se ficassem diante destas questões com maior frequência.

Continuando, olhando algumas páginas antes da passada citação, encontramos o seguinte (BNCC, pp. 549-50):

"A contextualização social, histórica e cultural da ciência e da tecnologia é fundamental para que elas sejam compreendidas como empreendimentos humanos e sociais. $\mathrm{Na}$ BNCC, portanto, propõe-se 
também discutir o papel do conhecimento científico e tecnológico na organização social, nas questões ambientais, na saúde humana e na formação cultural, ou seja, analisar as relações entre ciência, tecnologia, sociedade e ambiente. [...] Ainda com relação à contextualização histórica, propõe-se, por exemplo, a comparação de distintas explicações científicas propostas em diferentes épocas e culturas e o reconhecimento dos limites explicativos das ciências, criando oportunidades para que os estudantes compreendam a dinâmica da construção do conhecimento científico."

Essa proposta acena na direção do estudo da Natureza da Ciência. Infelizmente, na prática, isso é algo muito difícil de se realizar. Cabe agora um comentário com relação aos livros didáticos. Há coleções mais recentes que contém algum conteúdo de "contextualização histórica" como sugere a BNCC, mas isso costuma ser feito de maneira muito limitada. A maioria dos livros contém pequenos quadros com minibiografias anedóticas dos, assim considerados, grandes cientistas. O foco todo dos capítulos está concentrado em continuar ensinando as teorias tal como sempre foram ensinadas. Alguns poucos livros, como o Química Cidadã de Gerson Mol e Wildson Santos, que, inclusive, utilizo em minhas aulas, dão uma atenção maior ao tema da Natureza da Ciência: possuem textos maiores e mais profundos, complementados por sugestões de pesquisas e também questões específicas sobre o assunto. Normalmente, os textos vão bem além de simples biografias, relacionando a influência mútua entre vários cientistas que dedicaram-se ao problema em questão, bem como a influência direta que o assunto teve da, e sobre a, sociedade. Contudo, o livro não deixa de cumprir com todos os conteúdos tradicionais do ensino de Química no Ensino Médio. O resultado é um grande volume de conteúdo, cujo tempo limitado obriga o professor a escolher o que será passado. E é normal esperarmos que a maioria opte por ensinar os conteúdos tradicionais, abdicando da investida histórica e social proposta pelo livro, uma vez que conteúdos tradicionais são tão somente reproduções simplificadas do que se aprende em cursos universitários (e, por conseguinte, é o que a maioria dos professores possui de mais familiar). Falarei mais sobre a formação universitária na próxima seção.

\section{2 - Sobre a formação científica universitária}


Existem diferentes maneiras de se abordar os métodos com os quais os cientistas e os professores de ciências são formados em nosso meio universitário. Meu objetivo é apenas fazer considerações gerais, pois uma análise mais pormenorizada necessitaria de todo um trabalho (ou mesmo uma série de trabalhos) a isso dedicados. Esses trabalhos de fato existem, pois há muita pesquisa acadêmica voltada especificamente a resolver esse problema. O que farei aqui é apenas levantar certas considerações não muito controversas, sendo algumas delas baseadas em minha experiência pessoal durante os anos de graduação no Instituto de Física da Universidade de São Paulo.

O treinamento dos cientistas em nosso meio universitário ocorre predominantemente de maneira tecnicista. O padrão é simples: exposição de conteúdo teórico, a seguir assimilado por meio séries de exercícios de aplicação. As avaliações são simplesmente mais exercícios, do exato mesmo tipo que os realizados anteriormente. Há um grande descaso para com o tema da Natureza da Ciência. São bem poucas as disciplinas especialmente voltadas para o assunto.

Nossos cientistas são formados na base do "cala a boca e calcula", orientados a não se questionarem sobre "o que é massa?" ou "o que é carga elétrica?", nem a questionar as interpretações-padrão da Relatividade ou da Mecânica Quântica etc.. É dito a eles que esses questionamentos "não fazem sentido", ou que é "impossível encontrar respostas para elas". A seguinte descrição de Russell parece cruamente atual (2018, p. 381):

"Na física matemática, o tempo é tratado como algo constituído de instantes, embora se assegure ao estudante perplexo que instantes são ficções matemáticas. Não se esboça nenhuma tentativa de the mostrar por que ficções são úteis, nem como elas se relacionam com aquilo que não é fictício. Ele descobre que, por meio desses contos de fadas, é possível calcular o que realmente acontece e, depois de um tempo, ele provavelmente deixa de se atormentar com os motivos de isto acontecer."

Sendo bastante sincero, parece que a situação atual da maneira como nossos cientistas são formados é ainda pior. Os professores nem se dão o trabalho de avisar aos alunos que "instantes" e tantos outros conceitos abstratos são, de fato, fições (pergunto-me quantos cientistas renomados da atualidade têm realmente consciência 
de que falam de ficções enquanto pensam estar falando de realidades...). Tais ficções são ensinadas como verdades autoevidentes da Natureza: fatos cujo questionamento é pura perda de tempo. Infelizmente, na formação científica, os fundamentos (zona onde se encontram os "contos de fada" de Russell) são sumamente ignorados e a acriticidade leva à formação de cientistas "antifilosóficos".

Não entendo como pode ser concebível uma formação científica sólida e consistente sem, no mínimo, um profundo estudo em Teoria do Conhecimento. Um aluno comum passa toda a sua graduação sem ser questionado acerca da validade do que se aprende. Qual o fundamento das teorias? Quão válidas são as leis? O que significa "validade", afinal? Quando li o seguinte comentário de Kuhn n'A Revolução (p. 270), e comparei com a minha própria formação, não pude menos do que concordar:

"A educação científica não possui algo equivalente ao museu de arte ou à biblioteca de clássicos. Daí decorre, em alguns casos, uma distorção drástica da percepção que o cientista possui do passado de sua disciplina. Mais do que os estudiosos de outras áreas criadores, o cientista vê esse passado como algo que se encaminha, em linha reta, para a perspectiva atual da disciplina. Em suma, vê o passado da disciplina como orientado para o progresso. Não terá outra alternativa enquanto permanecer ligado à atividade científica."

Nesse contexto, há uma série de assuntos que são tão distorcidamente abordados que é capaz de gerar a ideia exatamente inversa da realidade. Um exemplo é a abordagem feita com relação à física aristotélica. As poucas vezes em que o tema é abordado, o é de forma verdadeiramente irresponsável. Somando-se tudo o que ouvi sobre o assunto durante a graduação, época em que não estudei nada a respeito disso por mim mesmo, mas apenas conhecia a partir dos livros-padrão e de uma ou outra aula em que o tema fora mencionado, acreditava que Aristóteles foi um ingênuo, um tolo mesmo, que havia deixado a superstição e "achismos" dominar a sua razão e tirar conclusões absurdas acerca do mundo físico. E isso, de maneira alguma, foi uma especificidade minha: essa é simplesmente a imagem que é transmitida, explícita ou implicitamente, pelos livros, professores e também divulgadores.

Nas raras vezes em que a questão sobre o motivo das "ideias ingênuas" de Aristóteles terem prevalecido (prevaleceram mesmo?) por nada menos que 1900 anos na história do Ocidente, a resposta dada sempre fora a de que "a autoridade de 
Aristóteles não era questionada", ou então que "na Idade das Trevas" não havia preocupação com o "saber científico verdadeiro" pois "não se fazia verificações empíricas", o que levou a aceitação sem contestação de tais ideias ingênuas. Hoje vejo a grande falsidade que é essa concepção.

Como seria possível que entre Aristóteles e Galileu (ou mesmo Copérnico) nem uma única pessoa tivesse tido a ideia de questionar as concepções deixadas pelo primeiro? Será que, de fato, foi assim que ocorreu? É evidente que isso é completamente implausível, apesar de ser assim mesmo ensinado. Vejamos, primeiro, se as ideias aristotélicas eram tão absurdas tal como ensinadas ${ }^{118}$.

A realidade em que vivemos não apresenta situações de movimentos desprovidos de atrito, tornando a inércia um fenômeno muito bem oculto de nosso julgamento. O movimento orbital dos planetas não apresenta nenhuma relação trivial com a queda de corpos nas proximidades da Terra. Para todas as observações astronômicas das quais Aristóteles tinha conhecimento, a ideia de corpos celestes imutáveis (incorruptíveis, em seu próprio termo) era a única conclusão possível de acordo com o conjunto coeso de suas concepções metafísicas.

A física aristotélica, para muitos dos fins de interesse ocorridos entre 300 a.C. e 1600 d.C., era perfeitamente válida e continha muito de verdadeiro. O geocentrismo e as antigas leis que supostamente regiam os movimentos só passaram a ser vistos como problemas quando nossos interesses mudaram, quando a humanidade se viu diante, literalmente, de um Novo Mundo, quando houve condições intelectuais e materiais suficientes para que algo novo surgisse. Porém, essa concepção de uma "Revolução Científica" ocorrida pontualmente durante a época do Renascimento não se sustenta. A Ciência não parou de se desenvolver ao longo desse tempo. As ideias científicas de Aristóteles não foram aceitas em sua totalidade nem mesmo em sua própria época; nem mesmo em Atenas, a cidade onde viveu grande parte de sua vida e onde fundou sua escola, suas ideias possuíam monopólio ou predominância (Martins, 2001, p. 121).

Aristarco de Samos, pouco depois de Aristóteles, já havia colocado o Sol no centro do Universo e a Terra em movimento ao seu redor. Na mesma época, Epicuro assumia a existência do vácuo, um absurdo para o aristotelismo. A física aristotélica

$118 \mathrm{O}$ assunto é amplamente discutido no artigo "A física de Aristóteles: uma construção ingênua?" (Porto, 2009). Sobre o erro comum de dizer que toda a Idade Média foi dominada pelo pensamento de Aristóteles, ver Martins (2001). 
seguiu recebendo inúmeras outras críticas ao longo de toda a Idade Média: os sábios cristãos em geral, quando o conheciam, viam algumas de suas ideias como heréticas (como a ideia da mortalidade da alma ou da eternidade do Universo); questionou-se a concepção de movimento natural e movimento violento, assim como a existência do éter e dos demais elementos, incluindo suas propriedades; foi proposta, por Jean Buridan (1300-1358), a ideia do impetus (que antecipou o moderno conceito de momentum); também foi colocada em dúvida a velocidade supostamente constante na queda-livre dos corpos. E, é claro, não é demais lembrar que entre a morte de Aristóteles (em 322 a.C.) e a sua propagação pelas Universidades europeias (o que começou a ocorrer apenas por volta de 1200, ainda assim com sérias dificuldades ${ }^{119}$ ), suas ideias eram bem pouco conhecidas no Ocidente, uma vez que a reintrodução de seus trabalhos se deu principalmente através das traduções do árabe provenientes da península ibérica.

Durante a Idade Média tivemos figuras científicas de imensa envergadura, que poderiam, se tivessem o interesse em fazê-lo (e, muitos, como já dito, de fato fizeram), ter colocado em cheque a física aristotélica. Havia, sim, testes empíricos. Destacaramse muitos estudiosos nessa época; entre eles, temos Robert Grosseteste (1168-1253) e seu discípulo, o famoso Roger Bacon (1214-1294). Eles estudaram o método científico, tendo dado contribuições decisivas em Teoria do Conhecimento, além da ótica de lentes, da refração e do arco-íris, e os fenômenos das marés e das ondas. Entre os que se opuseram diretamente Aristóteles, temos Nicole d'Oresme (13231382), que antecipou várias ideias de Galileu e "criticou o argumento aristotélico a favor da concepção de que a Terra está em repouso no centro do universo" (Martins, 2001, p. 123) e o já citado Jean Buridan (1300-1358), que defendeu - "a partir de conhecimentos empíricos e experimentos - a teoria do ímpeto" (ibidem).

A ideia de que as ideias aristotélicas foram rejeitadas por completo durante o período chamado de "Revolução Científica" é igualmente falso: a Física de Aristóteles já estava sendo gradualmente contestada havia séculos, enquanto que nomes como Descartes e mesmo Galileu permaneceram adotando uma ou outra ideia aristotélica.

Enquanto o primeiro permaneceu defendendo a impossibilidade de um vácuo,

119 "Em 1210, e novamente em 1215, proibiu-se em Paris o ensino e até mesmo a leitura privada das obras de Aristóteles sobre filosofia natural. [...] Em 1272 foi promulgada a proibição de ensinar determinados artigos de Aristóteles, e em 1277 foram arroladas 219 proposições condenadas pela igreja". (Martins, 2001, p. 118) 
o segundo "manteve a crença na existência de movimentos naturais e violentos, por exemplo, o que levou a grandes problemas em sua própria física" (ibidem, p. 124). Com relação aos que seguiam a linha aristotélica (bem poucos, talvez nenhum de forma absoluta), o que é mais provável: que tenham sido tão "ingênuos" quanto supostamente o foi Aristóteles, crendo em "tolices" e "ideias sem fundamento", ou que tenham visto na física do Estagirita respostas satisfatórias para os fins que eram pertinentes em sua época? Diz o prof. Porto (2009, introdução):

"Pelo contrário, a física de Aristóteles foi uma construção teórica complexa, profundamente integrada a um pensamento filosófico extremamente abrangente e elaborada a partir dos elementos empíricos pela vivência humana mais imediata. A força intelectual desse pensamento, assentada sobretudo nessa abrangência e em um caráter fortemente orgânico, garantiu-Ihe a primazia como forma sistemática de conhecimento científico por cerca de dezoito séculos."

Ainda assim, essa última afirmação não é inteiramente verdadeira, como já adiantei. Os livros de divulgação e de história da Ciência para o público em geral costumam repetir essa ideia de que o pensamento científico aristotélico dominou por 18 séculos. Esse domínio não existiu na maior parte desse tempo. Mesmo pontualmente, é difícil identificar períodos em que de fato houve algum tipo de unanimidade em torno de Aristóteles. Ainda assim, é como predominantemente a história da Ciência é ensinada (e vemos no artigo do prof. Porto a reprodução desse tipo de ensino, mesmo quando suas intenções são justamente a de oferecer uma outra visão acerca da Física aristotélica).

O prof. Nussenzveig diz (2008, vol. 1, p. 35) que as ideias de Aristóteles, "baseadas em observações qualitativas, transformaram-se em dogma e predominaram durante cerca de 20 séculos!". Poderíamos buscar ter mais precisão com a história, da mesma forma como a exigimos na Física. Como acabamos de ver, as ideias de Aristóteles não predominaram durante cerca de 20 séculos (aliás, não eram 18 séculos? Ou serão 19?) — difícil é encontrar nomes que adotaram a visão da Física Aristotélica de forma absoluta. Mais difícil ainda é demonstrar que essas ideias se transformaram em "dogma". Mesmo que as ideias fossem adotadas como corretas, isso não as tornam dogmas automaticamente - caso se tornassem, muito da Ciência atual também deveria ser chamado de dogma. Houve críticos de Aristóteles em seu próprio tempo. Houve também largos períodos de tempo em que 
Aristóteles foi simplesmente ignorado ou relevado, com um ou outro pensador que, pontualmente, acataram as visões de Aristóteles. Na mesma página citada, o prof. Nussenzveig reproduz um trecho de Galileu com os famosos diálogos de "Salviati (que representava Galileu), Simplício (defensor de Aristóteles) e Sagredo (representando um observador imparcial inteligente)". Vemos que, possivelmente, é daí, do próprio Galileu, de onde surgiram as distorções acerca das "tolices aristotélicas". Mas há uma explicação. Diz o prof. Martins (1998, p. 119, [ ] meus):

"A visão dos aristotélicos tolos, teimosos, incapazes de ver seus erros, que se popularizou graças aos esforços retóricos do próprio Galileo, não descreve a realidade histórica da época. Pode ser que em Pádua, onde Galileo estudou, ele tivesse encontrado professores especialmente estúpidos - afinal de contas, foi lá que se refugiaram os averroistas radicais [esses sim, provavelmente os únicos aristotélicos em absoluto], quando tiveram que fugir de Paris."

Enfim, já é hora para o resultado da pesquisa acerca da história da Ciência, que desmascarou essa distorção ignara, passar às salas de aula e aos livros didáticos e de divulgação.

Ainda seguindo essa linha, diz Kuhn (2012, p. 319) que a gravitação de Einstein é mais próxima da concepção aristotélica do que a de Newton ${ }^{120}$. Onde está então a linearidade da evolução científica, daquela forma como a didática tradicional induznos a pensar? A teoria de Newton é mais próxima da realidade física do que a de Aristóteles? Se sim, como explicar um retorno a concepções aristotélicas, com uma roupagem renovada por Einstein? E se não é, porque trocamos a teoria de Aristóteles pela de Newton? E, pior, como pode ser concebível a formação de um cientista ou professor de Ciência que não passa por esses mesmos intensos debates e problematizações acerca de como o seu objeto de estudo se formou ao longo dos séculos?

Quando analisamos os currículos dos cursos de Filosofia e de Artes em geral,

120 Duas semelhanças que saltam à primeira vista são: (1) Tanto em Aristóteles quanto em Einstein, a ideia de ação à distância é completamente inexistente, enquanto esse é um conceito aceito (e, em grande parte, um calcanhar de Aquiles) da gravitação newtoniana e (2) o retorno de um "lugar natural" para onde os objetos tendem a se deslocar (o centro do Universo para Aristóteles e o "centro de distorção" do espaço-tempo para Einstein), sem o uso do conceito de força, mas com grande ênfase nos aspectos geométricos do problema. Bertrand Russell também notou isso (ver o capítulo 24 do primeiro volume da sua História da Filosofia Ocidental). 
não há um único curso acadêmico que não passe necessariamente por uma longa série de estudos envolvendo a história de sua disciplina. Não há a menor cogitação de se formar um filósofo, um pintor ou um compositor que não conheça tudo o que de mais valioso se produziu pela espécie humana, da antiguidade à modernidade, em sua área específica de estudo. Então por que há tanto descaso com relação a isso na formação de nossos cientistas e professores? Por que, em média, um compositor precisa de 5 anos para se graduar, enquanto um bacharel em Física precisa de 4 [!] e um professor da mesma disciplina, em certos cursos de graduação, precisa apenas de 3 [!!!]? A História mostra que os grandes cientistas tinham formação ampla e profunda, longe de serem meros "resolvedores de exercícios" ou "plotadores de gráficos". Sem isso, não podemos esperar feitos espetaculares de nossos cientistas, a não ser daqueles que, sedentos pelo saber, buscam independentemente daquilo que seus cursos de graduação Ihes oferecem. Sintetizam com grande clareza Bagdonas, Zanetic e Gurgel (2014, p. 253):

"[...] se pudermos nos dar ao luxo de permitir aos nossos cientistas terem um pouco mais de tempo para refletir criticamente sobre sua área de estudo; ou se quisermos formar cidadãos que possam analisar a ciência contemporânea de forma crítica, reconhecendo seu valor e os perigos oriundos da confiança cega em sua autoridade, então uma pluralidade de abordagens historiográficas e filosóficas Ihes devem ser apresentadas, desde a sua formação escolar."

Todas essas reflexões vim realizando desde o último ano de minha graduação, quando conheci, pela primeira vez, junto aos professores Zanetic e Gurgel, os filósofos da Ciência modernos, o que me lançou nesse caminho da Teoria do Conhecimento e da Filosofia em geral. Muito feliz fiquei ao ler as seguintes linhas de Carl Sagan ( $O$ Mundo Assombrado pelos Demônios, 1995, Prefácio):

"Na Universidade de Chicago também tive a sorte de me encontrar com um programa de educação geral desenhado por Robert M. Hutchins no que a ciência se apresentava como parte integral da maravilhosa tapeçaria do conhecimento humano. Considerava-se impensável que um aspirante a físico não conhecesse Platão, Aristóteles, Bach, Shakespeare, Gibbon, Malinowski e Freud... entre outros. Em uma aula de introdução à ciência, nos apresentou de modo tão irresistível o ponto de vista do Ptolomeu de que o Sol girava ao redor da Terra que muitos estudantes tiveram que repensar sua confiança em Copérnico." 
Não há como tomar conhecimento de relatos como esse sem pensar no tamanho ganho que obteríamos ao adotar semelhante programa de ensino. Não nego a necessidade de formar mais profissionais rapidamente, especialmente professores, cujo déficit em quantidade permanece bastante alto, mas não vejo como solução viável simplesmente continuarmos sacrificando a qualidade de nossos cursos em prol desse objetivo.

\section{3 - Breve análise de alguns livros clássicos de divulgação}

Nessa e na próxima seção farei uma breve análise sobre como alguns livros de divulgação abordam o tema da Natureza da Ciência. Dividi a análise em duas partes: a de livros clássicos e a de livros modernos. Como livros clássicos, considerei qualquer um que já tenha se consolidado como referência de divulgação, tendo sido premiado ou mesmo se tornado um best-seller. Entre os livros modernos, considerei aqueles que foram recentemente lançados e ainda não tiveram todas as oportunidades de mostrarem se serão ou não referências no futuro. Um ou outro tema, argumento ou citação desses livros também serão comentados, mesmo que não tenham relação direta com o tema Natureza da Ciência, mas que digam respeito especificamente a como a Ciência é divulgada em geral. Detalho mais adiante a metodologia utilizada para a análise. Aqui vale citar uma frase de Kuhn (2012, p. 83) que pareceu antever a realidade dos livros que serão analisados: "O cientista que escreve um livro tem mais probabilidades de ver sua reputação comprometida do que aumentada".

Sobre isso, o prof. Martins, em seu artigo (1998a) criticando uma conhecida obra de divulgação ( $A$ Dança do Universo, do físico brasileiro Marcelo Gleiser) disse:

"Os autores de livros de divulgação da ciência são muitas vezes mal vistos pela comunidade científica. Suas obras costumam ser acusadas de distorcer a ciência, na tentativa de apresentar algo compreensível a um público mais amplo. Muitas vezes isso ocorre realmente (e infelizmente). Por outro lado, deve o público ser privado de contato com o desenvolvimento científico? É claro que não. A cultura científica deve ser disseminada, e boas 
obras que a divulgue podem atrair novos talentos para a pesquisa. Atualmente, a comunidade está cobrando uma retribuição sociais dos cientistas, e a divulgação científica poderia ser uma das formas pelas quais o público receberia um retorno do investimento feito com o dinheiro dos impostos. O problema é encontrar quem possa fazer bons trabalhos de divulgação científica. $O$ ideal (difícil de atingir) é unir uma competência nessa área à capacidade de escrever de modo simples e interessante, mas não errôneo."

A crítica do prof. Martins se dirige especialmente a aspectos puramente conceituais da Ciência. Ou seja, diz respeito à divulgação da Ciência de uma maneira conceitualmente correta. Isso inclui, evidentemente, não apenas a explicação de teorias, mas também não cometer erros historiográficos ou interpretações errôneas dos próprios eventos da história da Ciência. Além da possibilidade de conter erros conceituais, muitos livros de divulgação são escritos sem o embasamento necessário em história da Ciência, o que gera muitos equívocos na maneira como os temas são apresentados. Porém, ainda há um outro ponto, ao meu ver, no mínimo tão importante quanto os anteriores: a divulgação correta da Natureza da Ciência. É claro que a história da Ciência integra vitalmente o conceito de Natureza da Ciência, mas a divulgação também precisa levar em consideração (e falar sobre o assunto com propriedade) a Filosofia da Ciência, especialmente no que diz respeito à epistemologia. Isso inclui abordar a questão do alcance e validade dos conhecimentos científicos, a natureza das leis e das hipóteses, o papel da Metafísica, da teorização, do experimento etc. Nesse ponto, como veremos logo adiante, a maioria dos livros de grande circulação comete erros graves. Um dos resultados da divulgação científica mal feita é uma divisão de dois mundos: de um lado, o mundo da Ciência real, tal como ela é praticada e tal como ela é fundamentada; do outro lado, o que o público em geral pensa ser a Ciência, baseados no que aprendem por meio dos veículos de divulgação. Nenhum resultado positivo pode sair dessa divisão: algumas pessoas vão se sentir atraídas pela Ciência pelos motivos errados (o que poderá acarretar em mais distorções, em reproduções e propagações destes mesmos erros, ou ainda em decepções etc.) enquanto que outras pessoas vão se sentir repelidas pela Ciência também pelos motivos errados (vendo a Ciência como algo estranho, que fala sobre coisas irreais, que "pensa saber" coisas que em realidade não sabe, que é intransigente e dogmática etc.). 
Com isso tudo, incluindo os comentários que se seguem, pretendo reafirmar o cuidado que é necessário existir na formação de nossos professores, divulgadores e pesquisadores no estudo da Natureza da Ciência.

\subsection{1 - Método de Análise}

A presente pesquisa se insere na área de pesquisas qualitativas, com uma análise semelhante às análises de conteúdo, que buscam identificar ideias expressas explicitamente por um sujeito. Anteriormente foram justificados os motivos pelos quais as obras foram selecionadas. Todos os livros foram lidos na íntegra e em suas versões digitais. Isso significa que pode haver algum conflito na numeração das páginas referenciadas, porém os textos foram reproduzidos fidedignamente. Ao longo da leitura, busquei por trechos que abordavam a temática da Natureza da Ciência. Assim, selecionei todo trecho que dizia respeito ao método científico, ao papel e a natureza das teorias, hipóteses e experimentos, a como a Ciência progride e a como a Ciência e os cientistas se relacionam com a sociedade. Também separei todos os trechos que diziam respeito, direta ou indiretamente, a pseudociências, anticiência ou cientificismo. Diferente de muitos trabalhos desse tipo, não estava interessado em contabilizar ou sistematizar essas citações, nem de criar gráficos ou tabelas com tais contabilizações. Meu objetivo foi o de articular o que foi desenvolvido nos dois primeiros capítulos desse trabalho, mostrando como os equívocos que explicitei estão presentes (ou não) em alguns dos mais importantes e difundidos trabalhos de divulgação. Para cada trecho selecionado, dedico mais ou menos linhas de comentários, confrontando o que foi dito pelo divulgador e o que dizem os referenciais teóricos explorados nesta dissertação. Comecemos, então, com as análises.

\subsection{2 - O Mundo Assombrado Pelos Demônios - Carl Sagan - 1995}

Dentre os principais divulgadores de Ciência do final do século XX (Hawking, Sagan, Dawkins etc.), a figura de Carl Sagan certamente se destaca. Seu carisma e didatismo lhe deram visibilidade através de palestras, de duas dezenas de livros escritos e da popular série Cosmos (1980), que recebeu um remake recente (2014) apresentado por um de seus continuadores, o também astrônomo e divulgador Neil 
deGrasse Tyson. Seu livro de 1995, O Mundo Assombrado Pelos Demônios, permanece sendo um dos mais importantes no campo da divulgação científica. Ele se encontra, atualmente, quase vinte e cinco anos após o seu lançamento, como o livro de divulgação científica mais vendido no site brasileiro da Amazon ${ }^{121}$. Nele, podemos encontrar as principais características que vemos nos divulgadores de hoje: tendência ao agnosticismo, forte oposição à pseudociência e à anticiência, um linguajar que transmite um sentimento de maravilha e encantamento para com o conhecimento científico, manutenção de posicionamentos de viés positivistas e uma crença quase ingênua na capacidade dos cientistas de assumirem seus erros e aceitarem novas ideias. Como se vê, é uma mistura de virtudes e defeitos; mais virtudes do que defeitos, é verdade, mas esses últimos não podem continuar sendo ignorados. Vejamos então alguns trechos comentados no livro.

Sagan diferencia-se de outros divulgadores, especialmente de Dawkins, ao manter uma posição menos radical contra as religiões. Ele não deixa de apontar, severamente, os erros cometidos em nome delas, mas também não nega que elas têm um papel fundamental na sociedade. Um exemplo desse posicionamento pode ser encontrado na p. 31, quando ele diz existir "a possibilidade de que a religião e a ciência forjem uma relação poderosa contra a pseudociência", completando ao afirmar que "por estranho que pareça", acredita que "logo se unirão para opor-se a pseudorreligião [sic]." Não fica muito o claro o que ele quis dizer com "pseudorreligião", mas é possível que se trate de pseudociências com ares de (falso) misticismo, ao estilo da cientologia. Sagan também diferencia espiritualidade de religião, afirmando que é possível possuir a primeira, inclusive de forma compatível com o pensamento cético e científico, mesmo não estando ligado com a segunda. Afirma ele (p. 39) que "a ideia de que a ciência e a espiritualidade se excluem mutuamente de algum modo faz um mal serviço a ambas".

Um ponto muito recorrente em todo o livro é o da falibilidade humana. Para Sagan, a Ciência "tem uma apreciação muito mais pormenorizada das imperfeições humanas e da [nossa] falibilidade". Repetidamente, ele diz que os muitos casos de aparições, abduções, milagres, visões etc. devem ter sido simplesmente enganos ou alucinações. Em contrapartida, a Ciência teria meios de autocorreção, sempre

${ }^{121}$ https://www.amazon.com.br/gp/bestsellers/books/7841886011/ref=pd zg hrsr books, Consultado em 11/07/2020. 
mantendo a humildade (literalmente, ele diz: "[...] mantenho que a ciência é parte integrante da humildade") para reconhecer que não tem respostas para todas as perguntas. É uma pena que o ceticismo continue sendo reafirmado como a marca distintiva da Ciência, quando é em realidade uma atitude muito anterior a ela, tendo sido estudado e adotado primeiro pela Filosofia e pelos filósofos, e só então transmitido "hereditariamente" à Ciência.

Devido à sua grande influência nos divulgadores dos dias de hoje, esse mesmo discurso de "humildade científica" pode ser visto frequentemente na divulgação científica atual. É fácil entender o que Sagan pretende dizer com isso, mas é difícil negar que tal visão acaba entrando em choque com o tipo de afirmações categóricas normalmente realizadas por cientistas. Ao mesmo tempo que proclamam essa humildade e afirmam saber que toda teoria é incompleta e passageira, afirmam, sem pestanejar, quando e como o Universo, a vida e a humanidade surgiram. Também afirmam, com uma incrível e pretensa precisão, quando o nosso Sol irá explodir, quando a galáxia de Andrômeda irá colidir com a Via Láctea e até quando todo o Universo deixará de existir. Dizem também sobre a constituição do núcleo dos outros planetas e até da atividade sísmica que ocorre em outras estrelas! O próprio Sagan, após proclamar a humildade científica, diz que:

"A ciência nos ensina os aspectos mais profundos de origens, naturezas e destinos: de nossa espécie, da vida, de nosso planeta, do universo. Pela primeira vez na história da humanidade, podemos garantir [!] uma compreensão real de alguns desses aspectos."

Será que a humildade proclamada por Sagan é um tipo peculiar de humildade, e não a que simplesmente nos diz para nos colocarmos em nosso lugar? Aliás, não seria, inclusive, uma contradição a Ciência (ou, mais precisamente, o cientista afinal, a Ciência não é um "ente" capaz de agir por si) autoproclamar-se humilde? A autoproclamação da humildade não é justamente a negação da humildade mesma? Concluo que deve realmente se tratar de um tipo de humildade diferente (ou seria uma humildade inexistente?). Talvez isso explicasse a compatibilidade (?) entre considerar-se humilde e, depois, afirmar que "podemos garantir uma compreensão real" (existe uma "compreensão" que não seja "real"?) dos "aspectos mais profundos" da Natureza.

É evidente que há inúmeros estudos acerca de todos esses assuntos mais 
profundos da Natureza, com evidências sendo encontradas e novos modelos sendo criados e aperfeiçoados a cada dia, mas ainda assim continuam a ser afirmações extraordinárias, baseadas em teorias que podem mudar a qualquer momento. Como afirmar essas coisas com tamanha segurança, típica dos professores e divulgadores, pode ser compatível com a dita humildade? Essa contradição distorce completamente a visão de Ciência que temos defendido, reforçando duplamente o cientificismo: primeiro, assegurando que a Ciência detém o poder necessário para realizar tais afirmações; segundo, dando à Ciência uma virtude que outras instituições (Filosofia, Religião, História, Artes etc.) supostamente não têm, de forma que a Ciência ganhe essa "aura" que une sabedoria e virtude num único corpo que supera qualquer outro empreendimento humano.

Vejo duas alternativas a isso, que os professores e divulgadores poderiam adotar a fim de evitar a contradição:

(1) Assumir a humildade de fato, tomando um extremo cuidado ao fazer afirmações extraordinárias do tipo citado acima. Dessa forma, sempre dizer que nosso conhecimento acerca desses assuntos é de "tal ou tal forma", mas que assim é "até o momento", e que "novos dados podem surgir a qualquer instante, mostrando que estávamos equivocados". Não adianta nada afirmar que a Ciência é humilde e que suas teorias podem mudar, e no momento seguinte afirmar que "o Universo teve seu início há 13,8 bilhões de anos", omitindo que esse é, ele mesmo, um exemplo desses conhecimentos que podem mudar e até mesmo ser considerado absurdo num futuro mais ou menos distante. Gama (2011) contribui com essa discussão ao problematizar a autoridade científica que sustenta tais teorias cosmológicas, argumentando que teorias alternativas devam ter o seu espaço no ensino. Não será essa atitude, autenticamente honesta, de se admitir que a questão está ainda em aberto que afastará as pessoas que realmente estão interessadas em Ciência. Pelo contrário, atrairemos as pessoas realmente mais humildes e sinceras com relação ao seu amor pelo saber, imunes àquela decepção que muitos estudantes, dentre os que confiaram plenamente nos resultados da Ciência, passam quando dão-se conta pela primeira vez da fragilidade de certos conhecimentos supostamente "comprovados".

(2) Também há a opção de abandonar de uma vez por todas essa ideia de humildade, e simplesmente assumir como muito seguros os conhecimentos científicos, mesmo estes mais extraordinários. Se alguém perguntar sobre algum 
detalhe ainda não compreendido pela Ciência, podemos simplesmente dizer que "não temos a resposta ainda, mas há intensas pesquisas ocorrendo nesse campo", sem a menor necessidade de invocar a virtude da humildade. $O$ resultado seria o de passar ao público o sentimento real que os cientistas possuem: a maioria deposita realmente sua confiança e fé nos modelos que aprende na graduação e que depois utilizam em suas pesquisas. Isso é necessário para que a própria pesquisa ocorra, no sentido kuhniano de Ciência Normal. A fragilidade do conhecimento científico é deixada de lado, esquecida ou simplesmente ignorada, enquanto se faz a pesquisa; normalmente, são os filósofos epistemologistas, e não os cientistas mesmos, que estão constantemente questionando a validade dos conhecimentos científicos. Apenas em época de crise que um grande número de cientistas de fato decidem rever conceitos basilares (alguns cientistas, no entanto, se recusarão e se aferrarão às velhas concepções até o fim da vida).

Tão necessário quanto ser humilde é ser honesto. E é igualmente necessário ser coerente. Dessa forma, a solução (1) mantém a humildade, e, para manter a coerência com essa virtude, é obrigada a ser honesta e expor onde o conhecimento científico é mais frágil. A solução (2) exclui a humildade, mas ao menos é honesta em assumir a confiança que tem nos conhecimentos científicos, além de manter a coerência com o sentimento real do cientista praticante (ainda que, do ponto de vista da Teoria do Conhecimento, seja uma posição frágil e, do ponto de vista do público em geral, pareça muito mais intransigente). Já a combinação atual entre pretensa humildade com afirmações teóricas categóricas não é nem verdadeiramente humilde, nem honesta e nem coerente. Não vejo ganho para a Ciência que a divulgação permaneça sendo realizada dessa maneira. O próprio Sagan abre o primeiro capítulo do seu livro com a seguinte citação de Einstein: "Toda nossa ciência, comparada com a realidade, é primitiva e infantil... é no entanto a coisa mais preciosa que temos". Os divulgadores normalmente dão ênfase excessiva à segunda parte da frase, omitindo completamente a primeira. Particularmente, não conheço um único divulgador que tenha caracterizado a Ciência como "primitiva e infantil" sob qualquer aspecto - o mesmo é válido para professores.

Sagan inicia o capítulo 9 (p. 152) com a seguinte citação de Arthur Conan Doyle em Sherlock Holmes: "É um engano capital teorizar antes de ter dados. Sem dar-se conta, a gente começa a deformar os fatos para que se adaptem às teorias, em lugar 
de adaptar as teorias aos fatos". É evidente que Sagan concorda absolutamente com a afirmação do detetive Holmes. No entanto, a afirmação está equivocada. Devido à insistência com que essa ideia é afirmada, propagando uma visão distorcida do que é Ciência, vejo-me mais uma vez ocupado na tarefa de esclarecer esse ponto aparentemente muito difícil de ser compreendido.

Sir Arthur Conan Doyle nasceu em 1859, dois anos após a morte de August Comte. Essa foi a época em que o positivismo floresceu, concomitantemente com o estabelecimento dos grandes ramos da Física Clássica (exceto gravitação e grande parte da mecânica, já bem estabelecidas), assim como da Química e da Biologia (podemos incluir também a Geologia e muitos outros ramos das Ciências). É claro que o escritor imerso nesse ambiente intelectual, em plena Era Vitoriana, não poderia ter colocado palavras mais precisas (no sentido de representar o pensamento vigente) na "boca" de seu personagem. Felizmente, o século XX trouxe novos ares, com grandes reviravoltas científicas e filosóficas. Como pôde Sagan, em 1995, ignorar todo esse desenvolvimento e acatar tal visão empiricista, já solenemente superada na Filosofia da Ciência? É um fenômeno que permaneceu, para mim, muito estranho. Mais estranho ainda é encontrar a mesma ideia em livros de Ciência e proclamada por divulgadores em pleno 2019. A resposta para esse enigma é, no entanto, relativamente simples e já foi adiantada: ausência ou grave déficit de formação filosófica, especialmente em Teoria do Conhecimento. Buscarei, tão brevemente quanto possível, atacar novamente o problema, argumentando diretamente com o perspicaz Sherlock Holmes. Será fácil para o leitor perceber que tudo o que direi acerca do trabalho do detetive é plenamente aplicável à realidade dos cientistas, que são, ao final das contas, detetives da Natureza. Vejamos.

Alguém, para ser um detetive (ou cientista) competente, deve, antes de mais nada, receber um treinamento adequado. $\mathrm{E}$ em que consiste esse treinamento? Estudo de princípios, de teorias acerca do assunto em questão (no caso, de Ciência Forense) e também estudos de caso. Isso tudo equipa o detetive para ver o que ele precisa ver, a prestar atenção no que merece atenção, a ignorar o que é certamente irrelevante para o assunto, a perceber anomalias, discrepâncias e contradições etc. Sem esse equipamento, não é possível coletar dados. Em realidade, não existem dados se não existirem antes conceitos, hipóteses e teorias, acerca do que eles são (ou do que pode ser considerado como "dado") e do que eles significam. Teorias não 
emergem de dados; dados emergem de teorias. Teorias precisam ser inventadas, em um ato criativo que transcende a racionalidade e a dedução lógica sem, no entanto, violá-las. As consequências da teoria são racional e logicamente deduzidas dela, mas ela em si, não. E são essas consequências que dizem o que é e o que não é um dado relevante para a pesquisa. Isso é uma inversão completa do que fora afirmado pelo detetive.

Ao observar uma cena de crime, o Sr. Holmes já possui consigo uma vastíssima coletânea de teorias e hipóteses acerca de como crimes acontecem. Ele já sabe pelo que procurar. Para qualquer formato ou tamanho de mancha vermelha/amarronzada que ele encontrar, ele já saberá dizer se o sangue foi respingado ou se foi escorrido, se é fruto de um ferimento agudo ou de uma grande área de sangramento, se ele está lá há pouco ou há muito tempo etc.

Note-se que mesmo eu não tendo nenhum contato real com cenas de crime ou similares, já estou carregado de teorias que absorvi ou desenvolvi ao longo da vida, aprendidas por outros meios (inclusive, pela leitura de histórias do próprio Sherlock Holmes). Se eu chegasse a uma cena de crime hoje, levaria comigo toda essa bagagem teórica, que determinaria todas as interpretações que eu poderia dar às pistas encontradas (inclusive determinaria o que eu iria considerar como sendo uma pista).

O detetive poderá combinar vários fatores de várias de suas teorias para interpretar os dados que está coletando. Ele não criará uma teoria nova, a não ser que o caso seja de tal maneira inusitado que se recuse resolutamente a se adequar a todas as suas teorias prévias. Sim, o detetive, assim como o cientista, busca adequar os dados à teoria, e não a teoria aos dados, como é afirmado por sir Conan Doyle através de seu personagem. E mesmo no caso de ter que criar uma nova teoria, ele não vai extrair essa teoria dos dados. Ele terá que criar a teoria da mesma forma como um compositor cria uma sinfonia. Depois de criada, ele verá se os dados se encaixam na teoria. Talvez ele precise reinterpretar os dados - em outras palavras, a teoria muda os dados. Talvez a teoria Ihe diga que outros fatores, antes ignorados, possam ter alguma relevância para a compreensão do caso.

Enfim, sem um equipamento inicial de teorias, o Sr. Holmes sequer saberia o que olhar ou em que prestar atenção. Se as teorias emergissem dos dados, o treinamento inicial do detetive seria completamente irrelevante: qualquer pessoa 
suficientemente inteligente poderia analisar a cena do crime e concluir logicamente pela resposta correta (também é possível que alguém simplesmente, por sorte, acerte a resposta correta partindo de premissas equivocadas, mas isso é outra questão).

Por que não encontramos crianças prodígio em Filosofia e Ciência, sendo elas abundantes na Música, no Xadrez e na Matemática? Mozart era compositor já aos cinco anos de idade ${ }^{122}$. Magnus Carlssen tornou-se mestre internacional de Xadrez aos treze anos e Gauss já demonstrava incríveis proezas matemáticas aos dez. Essas três, e mais outras áreas, têm algo em comum: elas dependem pouco de bagagem conceitual prévia. Conhecendo-se as regras do jogo, uma criança ou adolescente inteligente e criativo poderá disputar em pé de igualdade com qualquer adulto ${ }^{123}$. $\mathrm{O}$ pensamento conceitual, absolutamente dependente da linguagem, é bem pouco requisitado nessas áreas. $\mathrm{O}$ caso de Mozart ilustra bem isso, pois ele já havia iniciado suas primeiras composições antes mesmo de ser alfabetizado. Isso é simplesmente impossível em Filosofia e em Ciência: ninguém que não domine plenamente a linguagem, os extensos corpos conceituais, as profundas abstrações, a tremenda sutileza das analogias, conseguirá se destacar nessas áreas. E tudo isso está inacessível a crianças: é necessário muito preparo prévio, treinamentos específicos, adaptação ao mundo abstrato dos conceitos, das generalizações, dos termos universais, enfim, do domínio pleno da linguagem simbólica e conceitual. Não é à toa que uma criança ouve entendendo pouco, ou nada, quando adultos estão falando sobre assuntos bancários, seguros, contratos ou política, mas pode muito bem, se for talentosa, Ihes dar um xeque-mate pouco tempo após aprender as regras do Xadrez!

$122 \mathrm{O}$ exemplo talvez pareça exagerado, pois Mozart é considerado por muitos como tendo sido excepcionalmente talentoso, mesmo entre os excepcionais. Não vejo assim: ele era, de fato, muitíssimo talentoso, mas creio que outras crianças-prodígio na música também teriam sido capazes de aprender a compor com tão pouca idade (não seria surpresa alguma se isso de fato ocorreu - ou ocorre - atualmente), caso tivessem as múltiplas condições favoráveis que Mozart teve. De toda maneira, podemos considerar ao menos dois outros famosos casos de compositores-prodígio na tradição da Música Ocidental: Felix Mendelssohn compôs uma de suas obras-primas (a música incidental para Sonho de Uma Noite de Verão) aos 17 anos, mesma idade em que Franz Schubert já havia composto dezenas de obras, incluindo o lied, considerado uma obra-prima, Gretchen am Spinnrade. Não há na história da Filosofia ou da Ciência alguém que tenha produzido uma obra-prima ou dado uma contribuição profunda e contundente com tão pouca idade.

${ }^{123}$ É evidente que a maturidade irá influenciar na natureza do material produzido, mas não será determinante no nível de qualidade do resultado final - uma criança teria sérias dificuldades para compor uma ópera com enredo intrincado ou propor um teorema de cálculo avançado, uma vez que esse tipo específico de produção já é muito mais exigente, conceitualmente falando; mas isso não invalida o argumento. 
Mas, voltando ao assunto principal, nem mesmo Comte ignorava a importância de uma teoria prévia (vide a citação que utilizei na seção 1.4), embora não the atribuísse importância absoluta. A filosofia do século XX, destacando a de Popper e a de Kuhn, enterraram definitivamente esse frágil conceito empiricista. Torna-se, então, injustificável que ele continue sendo ensinado e divulgado como característica dominante da Ciência. Reparem os leitores o quão difícil é essa questão e o porquê de tantas páginas estarem sendo dispendidas para atacar o problema, sob os mais diversos ângulos. Os livros de divulgação continuam repetindo o erro. Professores reproduzem o erro em suas aulas e também nos livros-texto padrão utilizados no treinamento de jovens cientistas (lembremo-nos do próprio Curso de Física Básica do prof. Nussenzveig, já citado).

No capítulo 10, p. 170, Sagan faz uma observação um tanto quanto perigosa: "As afirmações que não podem provar-se, as asseverações imunes à refutação são verdadeiramente inúteis, por muito valor que possa ter para inspirar-nos ou excitar nosso sentido de maravilha".

Havia, naturalmente, um contexto para o qual essa afirmação era bastante verdadeira. Sagan se referia a um exemplo de asseveração de fato inútil para a Ciência: se alguém disser que há um dragão invisível, imponderável, que cospe um fogo que não queima, que não pode ser detectado nenhuma maneira, então essa é evidentemente uma afirmação não-empírica, metafísica. Porém, não é o fato de ser não-empírica ou metafísica que a torna inútil, como Sagan dá a entender. É, sim, em realidade, o fato de que a existência de uma entidade como essa não gera nenhuma consequência detectável, nem em nosso mundo da experiência (pois, nesse caso, seria uma afirmação empírica), nem em nossos paradigmas científicos (onde, de fato, afirmações metafísicas - não-empíricas - têm muito peso). Todo princípio metafísico é imune à prova e à refutação. Mas alguns não só são úteis, como inexoravelmente necessários à Ciência. Já citei muito o Princípio da Causalidade. Também já incluí até a própria Seleção Natural nesse conjunto. Ambos são princípios metafísicos, quase-tautológicos ${ }^{124}$, impossíveis de serem provados ou refutados, mas

124 Sobre o Princípio da Causalidade: todo fenômeno é causado por outro, chamado "causa". E o que é esse fenômeno chamado "causa"? É o fenômeno que causou o primeiro! Sobre a Seleção Natural: os indivíduos mais aptos sobrevivem. E quem são os indivíduos que sobrevivem? São os mais aptos! Apesar disso, chamei-os de quase-tautológicos, pois, ao contrário de uma verdadeira tautologia ("Essa mesa é uma mesa"), tais conceitos metafísicos ajudam a explicar muitos fenômenos empiricamente verificáveis. Ver Popper (1997). 
sem eles simplesmente não há Ciência. Há outros casos tantos de afirmações impossíveis de serem provadas, mas que seria absurdo chamá-las de "verdadeiramente inúteis". A testemunha ocular de um crime, que não teve a oportunidade de registrar o seu flagrante de nenhuma forma, simplesmente não tem como provar a sua acusação. É por isso uma ideia "verdadeiramente inútil"? O que pode "ser provado" é uma parcela mínima de tudo o que se há para saber e de tudo o que é possível se saber de fato. E até o que pode "ser provado" só o pode por estar apoiado sobre outras afirmações, ou princípios, que não podem eles mesmos serem provados, mas que justificam a afirmação habilitada a ser provada e a própria prova em si mesma, seja pela lógica, seja pela simples admissão a priori daqueles princípios.

Ainda dentro desse assunto, na p. 180, ele diz que "esse tipo de 'explicações' que podem explicar tudo, em realidade não explicam nada". De fato, mas isso não é necessariamente algo ruim da forma como, claramente, sugere Sagan. Novamente, há casos verdadeiramente inúteis, como o do dragão invisível. Mas os Princípios Metafísicos não são inúteis. Realmente, eles não explicam nada. Mas nunca foi a intenção que eles explicassem. Eles não servem para explicar. Eles justificam as explicações posteriores e, mais importante, a busca por elas. Alterando a configuração de um circuito, alguém percebe um aumento da temperatura nos fios. Isso poderia simplesmente ser ignorado. Mas o cientista está armado com o Princípio da Causalidade, o rei de todos os axiomas metafísicos: ele sabe que, se procurar, ele encontrará a causa do aumento da temperatura. Não há como provar que a causa realmente existe. Alguém poderá questioná-lo: "por que gastas tanto tempo e recursos procurando por uma resposta que tu não tens como saber que existe?". A única resposta que ele pode honestamente dar é que possui absoluta fé metafísica no Princípio da Causalidade - de que fenômenos não ocorrem aleatoriamente ${ }^{125}$ nem podem se produzir sem a preexistência de algo adequado que thes dê origem. Frente a essa fonte de esperança, motor de toda a Ciência, alguém diria que o Princípio da

\footnotetext{
125 Já fiz essa ressalva em outro lugar, mas não é demais reforçar: alguns autores dizem, erroneamente, que a Mecânica Quântica "refutou" o Princípio da Causalidade. A confusão aqui é clara: esses autores estão se referindo ao Determinismo, que de fato contraria a suposta indeterminação quântica intrínseca da Natureza. Mas os fenômenos quânticos continuam tendo suas devidas explicações (ou seja, possuem causas), com eles próprios explicando muitos outros fenômenos (são causas para outros fenômenos), e a fé metafísica no Princípio da Causalidade levará os cientistas a possivelmente descobrirem no futuro "as causas das causas" das leis do mundo quântico (ou, ao menos, os motivará a continuarem buscando indefinidamente).
} 
Causalidade é inútil?

O ponto principal nessa análise da afirmação do livro de Sagan consiste no que poderíamos denominar de "responsabilidade pedagógica". O grande nível de influência de professores e divulgadores sobre os estudantes e sobre o público leigo em geral é inegável. É claro que isso varia de público para público, assim como de professor/divulgador para professor/divulgador. Mas, no caso de Sagan, podemos dar como certa a sua marcante influência, admitida abertamente por muitos divulgadores e professores da atualidade (lembro-me agora de um professor de biologia do curso pré-vestibular onde estive matriculado, que foi quem me fez tomar conhecimento da figura de Sagan ao apresentar um episódio da série Cosmos em sala de aula). Dada tamanha influência, o cuidado que o professor e o divulgador devem ter em suas afirmações deve ser redobrado. Um erro ao apresentar um conceito pode se propagar por gerações e mais gerações, nos afastando de nosso objetivo primordial: a busca pela honestidade intelectual, a clareza conceitual e o amor à Ciência pelo que ela é.

Como último exemplo, segue uma afirmação muito séria feita por Sagan (p. 325, [ ] meus):

"Sustento que a ciência é uma ferramenta absolutamente essencial para toda sociedade que tenha a esperança de sobreviver até o próximo século com seus valores fundamentais [?!] intactos [...] Não só a ciência abordada por seus praticantes, mas também a ciência entendida e abraçada por toda a comunidade humana. E, se isso não o conseguirem os cientistas, quem o fará? [!!!]"

Pergunto: quais são os "valores fundamentais" da humanidade? E, mais sério ainda, o que tem a Ciência a ver com esses valores? A afirmação é tão genérica e ambígua que pode servir a múltiplas interpretações, algumas delas verdadeiramente perigosas. A Ciência investiga o mundo natural. Essa é a sua função. Mas Sagan parece propor algo além disso. Ele sugere que a Ciência seja a guardiã que venha a "preservar intactos os valores fundamentais da humanidade". Mas a Ciência não trata de valores ${ }^{126}$, assim como a Natureza não se comporta baseando-se em valores. Os

${ }^{126}$ É evidente que a Ciência está, ela mesma, carregada de valores - aqueles que a maior parte da comunidade científica compartilha e também os valores individuais, mas isso não significa que ela trata de valores. Os valores que ela carrega têm origem no simples fato de ela ser feita por humanos, mas o seu objetivo não é encontrar ou determinar esses valores; ao contrário, é partindo de valores previamente adotados pelos cientistas que a Ciência visa entender o mundo natural. Os valores preexistem frente à Ciência. 
valores humanos não podem ser definidos nem defendidos com base na Ciência. Há toda uma polêmica envolvendo a influência de nossos genes e da evolução biológica em nossos comportamentos. Mas é evidente que a decisão de quais valores devemos considerar fundamentais não podem estar baseados em genética (um bom ensaio sobre esse tema é realizado em O Gene Egoísta de Richard Dawkins, obra que será analisada a seguir). Os valores podem ser definidos por instituições tais como as religiões, ou pelo ramo da Filosofia que denominamos de Ética, ou pela política, incluindo inúmeras outras condições sociais e culturais que possam estar envolvidas. A Ciência pode palpitar com um ou outro argumento pertinente, mas isso é tudo. A Ciência não tem o papel de ser a guardiã de nada além de seu próprio depósito de conhecimentos. Ela não tem, nem pode ter, o papel de "salvar o mundo". Ela não é a solução para todos os nossos problemas. Qualquer coisa diferente disso é cientificismo, carregado de todas as suas más consequências.

O próprio Sagan, na introdução do livro em questão, relata sobre Feira Mundial de Nova York, ocorrida em 1939-40, em que a Ciência era apresentada como essa quase milagrosa solucionadora dos problemas, anunciando um futuro brilhante. Dali cinco anos, a humanidade presenciou a detonação da Little Boy e da Fat Man. O próprio Sagan comenta (p. 358) que...

"Certamente, as aplicações da ciência podem ser perigosas e, como tentei sublinhar, virtualmente todo avanço tecnológico importante na história da espécie humana - até a invenção das ferramentas de pedra e o controle do fogo - foi eticamente ambíguo. Esses avanços podem ser usados por pessoas ignorantes ou más com propósitos perigosos ou por pessoas sábias e boas para o benefício da espécie humana."

Ora, fica evidente que a questão dos valores transcende o que a Ciência é capaz de fornecer. É de uma irresponsabilidade tremenda colocar sobre os ombros da Ciência a tarefa de nos salvar de nós mesmos. E ainda não está clara de quais "valores fundamentais" Sagan se refere (sem nenhuma conotação pejorativa da minha parte): seria aos valores dos aborígenes australianos? Dos nômades da África subsaariana? Aos dos califados árabes? Aos do Partido Comunista Chinês? Aos do "homem branco" europeu e cristão? Ou, talvez aos do "homem branco" norteamericano e ateu/agnóstico, grupo ao qual ele próprio pertenceu?

Algo similar ocorre com os sistemas educacionais públicos do Brasil. Sobre a escola, recai similar responsabilidade de "salvadora da pátria" ou mesmo "salvadora 
da humanidade". A escola hoje não deve apenas ensinar as disciplinas tradicionais (as quais, concordo, não atendem às necessidades nem do jovem nem da sociedade como um todo), mas também deve ensinar valores morais e cívicos, deve lhes capacitar a uma profissão, deve alimentar e vestir seus alunos, Ihes dar uniforme e materiais escolares, devem abrigá-los pelo máximo de tempo possível, protegê-los, tratar de seus problemas psicológicos e também de seus problemas familiares, ensiná-los a seguir essa ou aquela ideologia, deve formar "cidadãos conscientes", que "saibam votar", que saibam fazer planejamento financeiro e familiar, ad nauseam.

Similarmente, as universidades não mais são instituições de ensino e de pesquisa de ponta e de excelência, mas são palco e meio para se resolver injustiças sociais, para realizar inclusão, para promover igualdade, para se fazer campanha política etc. Não nego que cada ponto desses é absolutamente importante e precisa ser necessariamente resolvido se queremos uma sociedade melhor. Mas é correto atribuir à escola e a universidade essas funções? São as instituições de educação, e a Ciência em geral, que irão resolver todos esses problemas e mazelas? Não deveriam existir instituições e áreas do saber específicas para isso? Não só deveriam, como de fato existem - mas parece ser muito mais fácil clamar por educação de forma genérica, esperando que ela realmente nos salve de todos os problemas.

Professores ensinam suas disciplinas específicas (inclusive professores de Ética, esses sim com boa oportunidade de auxiliar nesse aspecto), Cientistas investigam os fenômenos naturais, e cada uma das demais profissões realiza a sua tarefa particular. É correto atribuir a uma ou duas delas a exclusividade da função de "preservar intactos os valores humanos"? A pergunta final da afirmação de Sagan é crítica: "Se isso não o conseguirem os cientistas, quem o fará?". Aqui, claramente Sagan diz que é do cientista, e somente dele, a responsabilidade por essa preservação. Afinal, se não ele, "quem o fará"? Isso insinua que, fora os cientistas, ninguém mais tem a capacidade, ou a responsabilidade, de fazê-lo. Mesmo que o leitor discorde dos pontos que estou levantando aqui (sei que alguns desses pontos são polêmicos, devido ao consenso geral de que a escola e a universidade têm, sim, essas tarefas de "justiceiras sociais"), espero que ao menos concorde que a afirmação de Sagan é demasiado arriscada para ser feita da maneira como foi - em um livro para se divulgar a Ciência, dando a ela "superpoderes" e uma responsabilidade que a maioria dos cientistas, creio eu, não aceitaria assumir. 
O livro de Sagan é longo e há muito mais que poderia ser comentado, mas, para fins de brevidade, passarei ao próximo livro analisado. Concluo apenas reafirmando que a visão de Ciência abordada por Sagan continua sendo uma das mais influentes nos meios de divulgação atuais, tanto em seus pontos positivos quanto nos negativos. Entender a forma como a divulgação é feita hoje passa, inevitavelmente, pela obra e pelo legado de Carl Sagan; talvez esse trecho da presente dissertação inspire outros pesquisadores a investigarem em maiores pormenores a influência total que teve o premiado astrônomo norte-americano no ambiente de educação científica atual.

\subsection{3 - O Grande Projeto - Stephen Hawking e Leonard Mlodinow - 2011}

Lançado mais recentemente do que o anterior, este livro rapidamente se tornou um best-seller, algo que fora potencializado pela fama de seus autores. O físico Leonard Mlodinow é o autor de um outro livro popular que trata de estatística e aleatoriedade no nosso cotidiano, O Andar do Bêbado. É também autor do excelente A Janela de Euclides, que conta de forma acessível a história da geometria. Mas o nome que aparece escrito com letras garrafais na capa de $O$ Grande Projeto é o do famosíssimo Stephen Hawking, um dos rostos mais conhecidos da Ciência na virada do nosso século. É difícil dizer quais das ideias contidas no texto pertencem a cada autor (ou se todas são plenamente compartilhadas por ambos), mas como a figura de Hawking está mais associada à Ciência e à Física, para fins de análise considerarei que Hawking embasou e concordou com tudo o que está escrito sobre Ciência no livro.

Na presente dissertação, já comentei uma passagem do livro, a qual considero conveniente reproduzir explicitamente a seguir, que é uma das mais arriscadas (para dizer o mínimo) que poderiam ser ditos por alguém que busca o saber (p. 5, itálicos e [ ] meus):

"[...] as pessoas sempre fizeram muitas perguntas: Como podemos entender o mundo em que nos encontramos? Como o universo se comporta? Qual é a natureza da realidade? De onde veio tudo isso? O universo precisou de um criador? [...] Tradicionalmente, essas são questões para a filosofia, mas a filosofia está morta [!!!]. A filosofia não tem acompanhado a evolução da ciência moderna [?!], particularmente da física. Os cientistas se tornaram 
os portadores da tocha da descoberta, em nossa busca pelo conhecimento. A proposta deste livro é dar as respostas que são sugeridas por recentes descobertas e avanços teóricos."

Vê-se que (1) os autores não entendem em absoluto a natureza e a função da Filosofia ou (2) simplesmente ignoram essa mesma natureza e função para cumprir com seus propósitos (presumivelmente, polemizar). Se estivéssemos vivendo em uma época anterior ao positivismo, poderíamos concluir por (2) de imediato sem grande risco de erro, uma vez que dificilmente um cientista de renome seria um completo leigo em Filosofia. Infelizmente, nos dois últimos séculos vimos uma progressiva investida contra a Filosofia, sua perda de prestígio frente a um proporcional aumento do prestígio científico e, por fim, a sua redução ou mesmo eliminação dos programas de graduação científica. Dessa forma, não seria de se espantar se os autores não se deram conta que declararam a morte da Filosofia em um livro de Filosofia! Pois $O$ Grande Projeto não é outra coisa senão isso: o uso de "recentes descobertas e avanços teóricos" para justificar especulações filosóficas; em especial, especulações metafísicas.

Sobre a natureza da Filosofia, creio que o melhor expositor do passado século tenha sido Bertrand Russell — filósofo esse que é quase impossível não ser conhecido por Mlodinow e Hawking (Mlodinow certamente o conhecia, pois cita-o em seus livros). Lembremo-nos da citação de Bertrand Russell, presente seção 1.6, que situa a Filosofia no ponto intermediário entre a Teologia e a Ciência.

Os divulgadores de Ciência, seguindo a tradição de Carl Sagan de exaltação à Ciência, parecem se fascinar com os notáveis avanços e conquistas que ela nos proporcionou. Esse fascínio tende a nublar a nossa visão com relação ao desconhecido; passamos a crer que sabemos muito; no último estágio, acabamos ignorando o alerta de Russell, esquecendo-nos do quanto nos é impossível saber. A insensibilidade que se segue nos afasta das questões importantes que a Ciência não alcança. Não vejo ganho algum, mas muita perda, se tal insensibilidade continuar a ser propagada nos meios de divulgação.

E sobre a afirmação de que "a filosofia não tem acompanhado a evolução da ciência moderna", o erro fica evidente quando nos damos conta daquele caráter residual assumido pela Filosofia que comentei na seção 1.6, também apoiado em Russell: as teorias mais gerais, os axiomas fundamentais, os princípios primeiros utilizados pela Ciência surgem da Filosofia. Quando algumas dessas proposições fica 
ao alcance de nossos testes empíricos, elas deixam de serem consideradas como Filosofia e entram para o campo da Ciência específica a qual dizem respeito. $O$ resultado é essa falsa impressão de que a "ciência moderna" está à frente da Filosofia, "carregando a tocha da descoberta", sendo que a realidade é justamente a oposta: é a Filosofia que abre os caminhos, que se dá ao luxo de arriscar mais, de ser a "ponta de lança" da investigação, de especular mais em suas investidas em busca de tudo o que é possível, para só depois a Ciência revelar, dentre esses inumeráveis mundos possíveis, qual é o nosso mundo. Para completar, a Ciência não possui existência independente da Filosofia por ser absolutamente impossível aniquilar tudo o que de Metafísica permeia tanto as suas teorias quanto suas decisões de cunho metodológico e epistemológico. Os autores seguem na p. 8:

\footnotetext{
"Por que existe algo ao invés de nada? Por que existimos? Por que este conjunto específico de leis e não algum outro? Esta é a Questão Fundamental da Vida, do Universo e de Tudo."
}

Completo dizendo que são, por excelência, questões filosóficas. Os autores quiseram sepultar a Filosofia com o livro, mas fica evidente que não o conseguiram ao contrário, reafirmaram-na por estarem escrevendo, justamente, um livro de Filosofia.

Seguindo com os comentários, a quantidade de erros, e até mesmo de absurdos, que o livro contém é enorme, variando desde erros historiográficos até erros lógicos e epistemológicos. Na p. 13 os autores afirmam que Empédocles descobriu o ar. A afirmação é tão absurda que acreditei ser um erro de tradução ou edição, mas a versão original, que consultei a seguir, diz textualmente "he had discovered the material substance we call air". Seria interessante ouvir dos Sres. Hawking e Mlodinow o que eles acham (ou achavam) que os gregos acreditavam estar respirando. Eles citaram os experimentos feitos por Empédocles, que permitiriam, sim, estabelecer certas propriedades do ar, mas dizer que "a substância material que chamamos de ar" foi descoberta é fora de propósito. O erro provavelmente está baseado no relato muito similar feito por Russell em sua História da Filosofia Ocidental (1957, pp. 66-7),

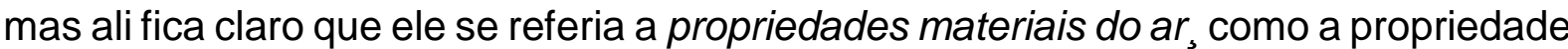
da impenetrabilidade, e não ao ar em si.

Na p. 14, afirmam que Tomás de Aquino (que viveu no século XIII depois de Cristo) foi um dos primeiros filósofos cristãos. Na versão em português que li, dizia 
literalmente que ele fora o primeiro - uma consulta à versão em inglês revelou que originalmente o texto dizia "the early Christian philosopher Thomas Aquinas". Creio que esse erro histórico derive daquela comum, e errônea, concepção de que a Idade Média foi dominada pelo aristotelismo e, sendo Tomás de Aquino o mais proeminente aristotélico cristão do período, uma possível (mas muito forçada e certamente falsa) visão sobre ele é que, de fato, se trata de um nos primeiros "filósofos cristãos". Os próprios autores "escorregam" nesse ponto, na p. 30, ao atribuírem a Santo Agostinho o mesmo termo ("early Christian philosopher") atribuído a Tomás de Aquino, ainda que Agostinho tendo vivido quase mil anos antes! Entre outros filósofos medievais pertencentes à cristandade, tivemos João Scoto, Anselmo, Abelardo e Alberto Magno, apenas para citar alguns.

No capítulo 7, os autores abordam o tema do Princípio Antrópico (em resumo, o princípio segundo o qual o Universo "é como é" devido a "nós sermos como somos"). Hawking explica o princípio em outro de seus bem vendidos livros Uma Breve História do Tempo (p. 180): "Vemos o universo tal como ele é porque, se fosse diferente, não estaríamos aqui para vê-lo". Em O Grande Projeto é dito que (p. 91) "embora possa soar como uma filosofia, o princípio antrópico fraco [existem outras versões] pode ser utilizado para fazer previsões científicas". Ora, o Princípio Antrópico não "soa como uma filosofia": ele é "uma filosofia".

Fica subentendido da citação que princípios filosóficos não servem para fazer previsões científicas (seja o que isso queira dizer), e, caso sirvam, não são mais filosóficos, mas são "científicos". Há aqui uma confusão de uma série de conceitos que seria facilmente evitável conhecendo-se apenas o básico sobre a natureza da Filosofia e até da própria Ciência, algo que seria esperado de cientistas como são os autores. Se com "previsões científicas" os autores estejam se referindo a previsões testáveis, empíricas, então não há impedimento algum para que certos princípios filosóficos atendam a esse critério. Tomemos o princípio filosófico da constante mudança de Heráclito. O princípio em si mesmo prevê que os entes que nos rodeiam, incluindo seres inanimados e animados e até a nós mesmos, estão sempre mudando suas características. Isso não é, porventura, algo perfeitamente verificável empiricamente?

Escolha um critério de mudança e as condições iniciais de observação de um ente qualquer; realize medições e conclua se houve ou não mudança. Isso é ou não 
é Ciência? Toda a Ciência adota o Princípio da Causalidade, que prevê que encontraremos causas adequadas para quaisquer fenômenos observados. Isso não é uma previsão empírica? Se a questão for ausência de grandezas quantificáveis, o ponto é ainda mais elementar. A ausência de grandezas quantitativas não invalida uma previsão: muitas previsões biológicas, e até químicas e físicas são puramente qualitativas, ou de existência de entes ou de ocorrência de eventos, sem que um único número esteja envolvido. Aqui fica evidente a dificuldade de se demarcar o que é Ciência e o que não é: mesmo uma de suas características mais notórias, a de ser capaz de fazer previsões empíricas, acaba se confundindo em determinados limites, criando uma zona intermediária, cinzenta, em que perdem o sentido, ou ao menos a precisão, as afirmações sobre o que deveria ser chamado de Ciência. Os autores poderiam ter evitado facilmente esse erro, mas eles queriam, ao máximo, dar a impressão que estavam falando de "Ciência pura" (é claro que essa impressão só seria acatada por um público muito desinformado). Afinal, estando eles escrevendo um livro de Filosofia, com muitas e muitas especulações puramente metafísicas, por que se preocupar em dizer, com outras palavras, que o Princípio Antrópico apenas "se parece filosofia, mas na verdade é Ciência"? Qual o sentido de alguém levar um copo d'água para tentar apagar um incêndio (incêndio esse, vale dizer, provocado pela própria pessoa)?

Na p. 44, os autores afirmam que "[...] as leis da natureza em nosso Universo surgiram do Big Bang". De fato, é o que afirmam os principais modelos aceitos atualmente. Porém, mais tarde, na p. 82, dizem que "flutuações quânticas levam à criação de pequenos universos a partir do nada". O problema aqui é de lógica mais elementar. Partindo dos próprios pressupostos dos autores, podemos nos perguntar: se há um "nada" prévio com relação aos universos "criados" por "flutuações quânticas", como poderiam essas mesmas "flutuações" existirem, se são frutos de "leis da natureza" que surgiram apenas depois "do Big Bang"? Nesse "nada" préUniverso ou pré-Big Bang não poderiam existir as leis da natureza que possibilitam as ditas flutuações quânticas. É verdade que algumas das descobertas mais recentes da Ciência desafiam, aparentemente, conceitos lógicos que acreditávamos ser dos mais básicos. Mas isso não significa que uma argumentação qualquer poderá simplesmente descartar um dos, também aparentemente, mais autoevidentes princípios filosóficos de todos os tempos: Ex nihil nihil fit - do nada, nada vem. 
A argumentação em $O$ Grande Projeto leva os autores a reafirmarem a sua posição quando dizem (p. 105): "Corpos tais como estrelas ou buracos negros não podem simplesmente aparecer do nada. Mas um universo inteiro pode". Mas um Universo não contém, por definição, tudo - se não em ato, ao menos em potência? Então, o nosso Universo sempre conteve, ao menos, os princípios (sejam forças, matéria, energia ou o que quer que seja) necessários para formar estrelas ou buracos negros. E se algo assim, tão completo e grandioso em si mesmo, pode surgir do nada através de flutuações quânticas, por que uma simples estrela e um buraco negro não poderiam? Esse tipo de afirmação conduziu-me a cogitar que os autores estavam somente interessados em criar polêmica e em fabricar um best-seller - o que, de fato, conseguiram, tornando o seu empreendimento, ao menos nesse sentido (possivelmente, apenas nesse sentido), altamente bem-sucedido.

A grande conclusão do livro é sintetizada pelos autores da seguinte maneira ( $p$. 105):

"Porque existe uma lei como a gravidade, o Universo pode e se criará a partir do nada [...]. A criação espontânea é a razão pela qual existe algo ao invés de nada, por que o Universo existe e por que nós existimos. Não é necessário invocar Deus para iluminar o papel de toque azul ${ }^{127}$ e colocar o Universo em movimento."

Concordo que pode não ser necessário, e certamente não é tarefa de um cientista, invocar Deus para encontrar explicações acerca do mundo natural, mas a argumentação toda simplesmente não faz sentido. Antes, foi dito que a criação espontânea era devida a "flutuações quânticas" (o argumento girava em torno da criação espontânea de partículas no vácuo quântico). Agora, a responsabilidade para a criação espontânea foi jogada sobre as costas da gravidade, justamente a única das forças fundamentais conhecidas que não possui um tratamento quântico adequado. É dada toda uma justificada baseando-se no fato de que a atração gravitacional produz uma energia potencial negativa, e que somado a outros efeitos poderia espontaneamente fazer surgir um (ou infinitos) Universo(s).

Para além do impasse entre decidir se a criação ex nihil do Universo tenha sido causado por flutuações quânticas ou pela gravidade, nesse último caso caímos em

127 "Light the blue touch paper" - expressão que significa fazer algo que provoque reações de raiva ou agressividade em outrem. 
um problema similar de causalidade: a gravidade, para existir, pressupõe, no mínimo e de acordo com o que sabemos até o momento, a existência de matéria e a existência do espaço-tempo. Não faz sentido falar em gravidade sem esses dois elementos. $O$ espaço-tempo sem matéria não possui gravidade. A gravidade é um fenômeno que está presente no espaço-tempo quando este abriga matéria, matéria essa que de alguma forma o distorce, dando origem aos diversos efeitos gravitacionais observáveis. Mas se o espaço-tempo e a matéria são entes ou fruto de leis da Natureza que, de acordo com os principais modelos e com os próprios autores, passaram a existir com o Big Bang, como poderiam eles terem gerado esse mesmo Big Bang? Talvez eles preexistissem antes do Big Bang. Mas, nesse caso, não seria uma criação a partir do nada: algo existia antes da grande expansão. A grande questão é: todas as leis da Natureza pressupõe a existência de entidades (até por serem, muitas delas, leis de interação entre essas mesmas entidades — interações que simplesmente não existiriam sem as entidades mesmas). Sem essas entidades, sequer faz sentido falar em leis. O que é a Lei da Gravidade em um não-espaço? O que é a Lei da Gravidade onde não há matéria de nenhuma espécie? Os cientistas podem tirar Deus da equação e não serem ridicularizados por isso (muitos podem até mesmo ser exaltados justamente por isso, como de fato alguns foram e são), mas jamais poderão tirar a lógica e não se verem severamente criticados por conta disso.

Após tudo o que se precedeu, infelizmente concluo que $O$ Grande Projeto reúne diversos exemplos de como não divulgar Ciência ${ }^{128}$ : imprecisões historiográficas, lógica duvidosa (para não dizer absurda), especulações filosóficas mascaradas com roupagem cientificista, ao mesmo tempo em que, levianamente, condena à morte a própria Filosofia. Quantos leitores leigos perderam qualquer interesse ou mesmo o respeito à Filosofia após ler esse livro? Quantos deixaram de estudar Filosofia unicamente porque o "genial Stephen Hawking disse que ela está morta"? Quantos foram atraídos para a Ciência carregando esses conceitos perniciosos, que levarão

${ }^{128}$ Sei que a crítica sintetizada nesse parágrafo é dura, mas note o leitor que ela é dirigida à obra e às ideias, e não às vidas pessoais e contribuições científicas dos autores. Além disso, não espero críticas menos duras à minha própria obra e minhas próprias ideias, venham essas críticas da academia ou de leigos. Sigo, por princípio, que o confronto dialético aberto é a forma mais rápida de se identificar e se corrigir erros, servindo como forte impulso para seguirmos progredindo na estrada do saber. 
adiante, talvez indefinidamente, em suas carreiras como cientistas? Creio que irresponsabilidade é a palavra que resume o assunto.

\subsection{4 - O Gene Egoísta - Richard Dawkins - 1976}

A sinopse desse livro já diz muito sobre o seu assunto e a sua importância:

"Um dos livros mais aclamados da história da divulgação cientifica, ele não só apresenta a biologia evolutiva de forma acessível, mas acrescenta uma interpretação metafórica que inspirou gerações de biólogos e simpatizantes: somos máquinas de sobrevivência a serviço dos genes. Desde a sua publicação, foi traduzido para mais de 25 idiomas e sucesso de vendas pelo mundo todo."

Este permanece sendo, até a atualidade, um dos livros de divulgação mais lidos e mais influentes de todos os tempos. Em 2017, em pesquisa realizada pela Royal Society, o livro foi escolhido como o mais influente ${ }^{129}$.

Em termos mais pessoais, é relevante mencionar que Dawkins tornou-se ainda mais famoso pela militância ateísta, indo para além da maioria dos divulgadores, que preferem adotar uma posição agnóstica ${ }^{130}$.

De todos os livros analisados, esse é o mais técnico e específico. Ele não é um livro sobre darwinismo - a Evolução é tratada como absolutamente verdadeira desde o início (o autor diz, na p. 8, que "hoje, a teoria da evolução está quase tão sujeita à dúvida quanto a teoria de que a Terra gira ao redor do Sol"). O livro trata de uma teoria específica, que é, sim, baseada na Evolução, mas é especificamente sobre Etologia (estudo do comportamento animal). Não focarei nos argumentos etológicos do autor; embora o assunto muito me interesse, não faz parte do escopo desse trabalho. Procurarei focar-me em aspectos pedagógicos e da Natureza da Ciência.

No capítulo 11, p. 147, há uma citação com especial valor para a presente dissertação:

$129 \mathrm{https}$ ://www.theguardian.com/books/booksblog/2017/jul/20/dawkins-sees-off-darwin-invote-for-most-influential-science-book, consultado em 12/07/2020.

${ }^{130}$ Com relação a isso, creio que o agnosticismo é a posição mais segura para alguém que prioriza o ceticismo em sua própria visão de mundo. Se alguém, dito cético, se posiciona como teísta ou como ateu, necessita, obrigatoriamente, de fatores extras para justificar sua posição. Pode, inclusive, ser motivada por conhecimento científico. O que é inadequado é dizer que a Ciência se posiciona dessa ou daquela forma. Isso seria distorcer sua natureza. 
"Há um sentido no qual a Ciência moderna realmente é melhor do que a Ciência antiga. Nossa compreensão do Universo não apenas muda com o passar dos séculos: ela melhora. Sem dúvida, a atual explosão de aperfeiçoamento data apenas do Renascimento, o qual foi precedido por um período sombrio de estagnação no qual a cultura científica europeia ficou congelada no nível atingido pelos gregos."

Como já pude abordar em outra parte, essa análise histórica, repetida até a exaustão, é falsa. Costuma-se associar o Renascimento e o período subsequente com uma suposta Revolução Científica, uma "explosão de aperfeiçoamento". Devido à recorrência do tema, cabe um adendo ao que já foi dito anteriormente. Diz o prof. Martins (2002, p. 125):

"Houve certamente importantes mudanças em várias das ciências durante os séculos XVI e XVII — aquilo que se costuma chamar de 'revolução científica'. Mas não houve nenhuma mudança brusca, bem definida, que tenha significado uma ruptura total com o passado, e é difícil descrever em que realmente consistiu a revolução científica, ou quais foram suas causas."

Em uma nota na mesma página, ele faz um interessantíssimo relato:

"Em 1990 participei de uma conferência promovida pela British Society for the History of Science, em Oxford, a respeito da revolução científica. Após três dias de apresentações de trabalhos e discussões, um ouvinte da plateia, meio desesperado, perguntou a um dos conferencistas: 'Mas afinal de contas, quando começou e quando terminou a revolução científica?' e a resposta foi: 'Ela começou na Antiguidade grega. E ainda não terminou'."

Entre 1976 e 1990 a pesquisa em historiografia da Ciência avançou notoriamente. Espero, sinceramente, que Dawkins tenha revisto essa posição que simplesmente não se sustenta nos acontecimentos históricos.

É certo que o Ocidente passou por um período especialmente sombrio durante os séculos de incursões bárbaras e dissolução do Império Romano, mas tal período é relativamente curto e o progresso foi retomado durante o restante da ldade Média (em particular, depois das iniciativas educacionais tomadas por Carlos Magno e Alcuíno). Diz o historiador Christopher Dawson, em A Criação do Ocidente (2016, pp. 24-5, [ ] meus):

"Somos, inapelavelmente, filhos do medievo. Os povos germânicos que invadiram e conquistaram o mundo romano a partir do século $V$, embora 
dominassem a metalurgia, encontravam-se, em termos culturais, sociais e econômicos, muito próximos às culturas neolíticas (sem escrita, sem vida urbana e sem Estado organizado). O retrocesso cultural foi simplesmente brutal, e é possível assegurar que a civilização quase desapareceu. Todavia, três séculos mais tarde, o Império Carolíngio era formado, o que propiciou um renascimento das letras e do conhecimento; mais quatro séculos e surgiram as grandes catedrais góticas, as universidades e o pleno desenvolvimento da vida urbana; mais três séculos e meio, navegação ultramarina, capitalismo e ciência [no sentido moderno, é evidente] aparecia, para fundar um novo mundo. Tendo como ponto de partida o quasi-neolítico germânico dos séculos $\mathrm{V}$ e VI e, como linha de chegada os Estados dinásticos do início da era moderna, no século XVI, contam-se aproximadamente mil anos. Do Neolítico à modernidade em mil anos! São muitos os historiadores que perceberam esse salto absolutamente impressionante."

Dawkins não era historiador, nem eu sou (embora tenha-me dedicado muito dos últimos anos ao estudo da história da Ciência); por isso mesmo podemos e devemos buscar embasamento nos historiadores para tirarmos nossas conclusões. 0 relato de Dawson, especialista na História Medieval do Ocidente, não se parece nada com o dito por Dawkins. É evidente que autoridade, quando o assunto é conhecimento, não significa nada ${ }^{131}$; contudo, de forma geral, a historiografia tem desmascarado essa visão de que o período medieval foi uma "Idade das Trevas" e já é hora de não mais reproduzirmos esse erro (esperemos que Dawkins não tenha continuado a fazê-lo).

Um último comentário sobre $O$ Gene Egoísta será feito acerca do seguinte dito de Dawkins (Capítulo 11, p. 152), onde afirma que "fé" significa "confiança cega, na ausência de evidência, ou mesmo diante dela". Esse é simplesmente o senso comum reproduzido até a exaustão por ateus, especialmente os de viés cientificista, como o é Dawkins. Creio ser impossível uma fé de fato cega em sentido absoluto, salvo casos de loucura diagnosticável. Reproduzindo uma citação de Russell (1957, p. 151): "Devo acreditar naquilo em que creio devido a alguma razão me levar a isso". Se a fé fosse realmente cega, não haveria nenhum motivo para acreditar em qualquer coisa em detrimento de outra. Poderia crer que Zeus iria me elevar ao Olimpo se eu Ihe

\footnotetext{
${ }^{131}$ Embora muitos se posicionem contra argumentos de autoridade, vemos que em diversos casos tais posicionamentos são insinceros: o caso curioso da completa submissão, tanto dos governos quanto por parte da população, às "autoridades científicas" nesse período de COVID-19 é um exemplo.
} 
rendesse culto, tanto quanto poderia crer que a louça da minha pia iria se lavar sozinha e em seguida me dar de presente a posse da Galáxia de Andrômeda.

Sejamos sinceros: se tivéssemos que escolher uma das duas crenças, qual delas pareceria mais plausível? Se pudermos escolher entre elas, é porque não é uma fé cega em absoluto: passou por nosso crivo racional. Escolhemos o que parece fazer mais sentido. E é exatamente por esse mesmo motivo que Dawkins possui fé não admitida na inexistência de divindades: por ser uma fé que lhe parece mais plausível que uma fé teísta qualquer. Muitos ateus argumentam que o ateísmo não é a "fé na inexistência de uma divindade", mas simplesmente "ausência de fé da existência dessa mesma divindade". É possível usar esse argumento.

Mas, (1) como nenhuma prova empírica é capaz de provar a inexistência do que quer que seja ("ausência de evidência não é evidência de ausência"), então essa "ausência de fé" precisa estar embasada em outro princípio que não ao da cultuada prova experimental. De fato, todos os princípios metafísicos de todas as nossas teorias empíricas estão mais além da prova experimental. Pergunto: que outro artifício, que não a fé, temos para aceitar tais princípios? Que outro artifício, que não a fé, temos para afirmar a inexistência do que quer que seja? Existem certas afirmações em absoluto que podemos fazer utilizando apenas a argumentação racional a priori: não preciso de fé para saber que, por mais que eu procure, não encontrarei um círculo quadrado; ou que, dentro de uma geometria euclidiana, possa existir um círculo cujo comprimento dividido pelo diâmetro não seja $\pi$. Também não preciso de fé para saber que todo ser é ele mesmo e não outro (Princípio da Não Contradição). Porém, obrigatoriamente necessitarei de fé para ser teísta. Ou para ser ateu. $E(2)$ isso não muda o fato de que as pessoas que têm fé a embasam em motivos, em julgamentos racionais, para escolher entre a sua fé e todas as demais "fés" concorrentes.

Dawkins fala sobre pessoas que mantém sua fé mesmo na ausência de evidência ou na presença delas. Imaginemos um caso extremo, como alguém que acredita ter sido abduzido por extraterrestres na noite anterior e é defrontado com uma gravação mostrando que ele não saiu de sua cama durante toda a noite. Imaginemos que, ainda assim, ele se recuse a acreditar que foi apenas um sonho. Se o questionarmos acerca do porquê de ele manter a sua posição mesmo diante de tal evidência, veremos que ele enumerará uma série de motivos: a experiência lhe pareceu real demais para ter sido apenas um sonho, a gravação pode ter sido forjada, 
dentre inúmeras outras possíveis. Se começarmos a desmascarar seus motivos, por exemplo mostrando que a gravação é autêntica, ainda assim ele poderá continuar a enumerar novos motivos para manter a sua crença. Mas notemos algo fundamental: se ele é capaz de enumerar motivos para manter a sua crença, é porque ele defrontou esses motivos contra as evidências mostradas, e julgou que tais motivos são mais dignos de sua crença do que as próprias evidências. Mas se houve julgamento, significa que não é uma escolha cega, como num sorteio aleatório. Ele avaliou a situação. Ele pode estar errando em sua avaliação, como todos nós frequentemente fazemos em situações menos extremas de nossa própria vida. Mas, se por um erro de avaliação, fazemos uma escolha que se mostra ruim ou falsa no futuro, não podemos atribuir isso a uma suposta fé cega: não somos loucos nem racionalmente cegos - teríamos escolhido o que mais fazia sentido na ocasião mesma de escolher, e só.

Afirmar que existe algo como uma confiança cega em algo, e denominar essa confiança de "fé" é ao mesmo tempo anticientífico (pois a Ciência não está, de maneira alguma, livre de elementos de fé) e antifilosófico (pois vai de encontro a uma argumentação lógica elementar baseada na Teoria do Conhecimento). É muito mais seguro, respeitoso e, certamente, mais verdadeiro (se é que, nesse caso, cabe dizer "mais verdadeiro"), falarmos sobre uma fé ou uma crença equivocada, uma crença que se mostrou não condizer com esta ou aquela observação, uma crença que não trás benefício ou que trás mesmo prejuízo, entre outros termos similares.

Enfatizo que essa última crítica e todas as precedentes tem apenas uma motivação: o quão grande pode ser a influência de um divulgador do porte dos avaliados. Essa influência pode ser fator determinante (há muitos motivos para acreditar que está sendo) nos rumos que a Ciência toma, e em como a sociedade se relaciona com esses rumos. Para o leigo simpatizante da Ciência, a palavra de um cientista de respeito é a verdade. Em meio a excelentes argumentos, outros não tão bem estruturados, ou efetivamente falsos, podem se infiltrar e serem indistinguíveis até mesmo por leitores mais críticos. Cabe então a estudiosos e pesquisadores, com fins de esclarecimento e não de conflito ou ataques pessoais, perscrutar esses argumentos, buscando expor as suas falhas. É claro que esses críticos e pesquisadores também podem se equivocar. $O$ que se espera deles, assumindo que 
sejam sinceros em sua busca pelo verdadeiro saber, é que estejam tão ou mais abertos a receber críticas e correções quanto estão dispostos a fazê-las.

\section{4 - Breve análise de alguns livros modernos de divulgação}

Nesta seção, além de um livro norte-americano, darei especial atenção um livro brasileiro lançado recentemente. Junto aos comentários dos livros, aproveitarei para falar um pouco acerca das demais atividades de seus autores.

\subsection{1 - Astrofísica para Apressados - Neil deGrasse Tyson - 2017}

Desde aproximadamente 2006, Neil deGrasse Tyson ganhou crescente fama como divulgador científico. Em 2014, foi responsável por apresentar o remake da série Cosmos (a versão original contava com Sagan), onde, no primeiro episódio, relata um encontro que teve quando jovem com Sagan e sua família. Fica evidente a continuidade existente entre ambos e o seu livro, Astrofísica para Apressados, possui muitas similaridades com os livros do falecido astrônomo.

Em linhas gerais, o livro é muito bom. É o mais curto dentre os analisados (cerca de 130 páginas). Os conceitos são apresentados de forma direta e com não mais detalhes do que o necessário. É claro que, eventualmente, leigos terão dificuldades de acompanhar o fluxo de informação, mas o próprio autor deixa claro que livro é uma espécie de aperitivo, e incentiva os leitores interessados a irem em busca de mais. Selecionei alguns trechos que considero pertinentes ao assunto desta dissertação, seguindo os critérios descritos na seção anterior. Os trechos serão comentados a seguir.

Na página 20, encontramos o seguinte ([ ] meus):

"Após 9 bilhões de anos de tal enriquecimento [dos processos do Big Bang], em uma parte banal do universo (a periferia do Superaglomerado de Virgem), em uma galáxia banal (a Via Láctea), em uma região banal (o Braço de Órion), uma estrela banal (o Sol) nasceu." 
Essa maneira de abordar o nosso lugar no Universo é típica da divulgação científica atual, algo em grande parte devido a Sagan e o seu famoso Pálido Ponto Azul. A visão de que a Terra (e, por conseguinte, a humanidade) estava no centro de um Universo relativamente pequeno começou a ser demolida a partir da Revolução Copernicana. Esse apelo à humildade de nos vermos como nada além de algo "banal" tem como base essa nova perspectiva da grandiosidade do Cosmo. O que esses divulgadores não percebem é que os exatos mesmos argumentos a favor dessa visão de "sermos banais" podem ser utilizados para recolocar a humanidade no centro das atenções. E o motivo é simples: apesar da grandiosidade do Universo, a Terra continua sendo o único lugar conhecido a abrigar vida. Criamos aqui coisas valiosas, entre Arte, Filosofia e Ciência, coisas essas que certamente são únicas e que nenhuma outra forma de vida, se existir, deve ter criado igual. Marcelo Gleiser, no livro A llha do Conhecimento (que será comentado a seguir), é um dos poucos divulgadores da atualidade (o único dentre os que comentei) que também aborda essa questão sob esse outro ponto de vista (Gleiser, 2014, p. 22, [ ] meus):

"Quatrocentos anos mais tarde [após a Revolução Copernicana], a busca por vida extraterrestre vem revelando a raridade de planetas como o nosso e, mais criticamente, a importância da vida humana. Consequentemente, o homem volta a ganhar relevância cósmica: importamos porque somos raros, agregados moleculares com a incrível habilidade de refletir sobre a nossa existência."

Cair no absurdo do antropocentrismo cósmico pré-copernicano é ridículo. Mas isso não significa que tenhamos que depreciar tanto assim a nossa existência, ignorando nossa raridade e o fato de que, até onde as nossas "vãs" ciências e filosofias conhecem, a nossa vida nesse planeta é tudo o que temos. Por fim, se nós, a Terra, e até a Via Láctea são todos banais, então a nossa Ciência, justamente o fator que nos levou a chegar a essa conclusão, é igualmente banal - então por que levar a conclusão a sério, para começo de debate?

Após refletir sobre o quão pouco sabemos sobre o que houve antes do início do Universo (ele toma como absolutamente certo que o Universo teve um início), Tyson diz que as ideias especulativas a esse respeito "nos lembram que a ignorância é o estado mental natural para um cientista de pesquisa" (p. 22). Essa ênfase em nossa ignorância é mais uma característica marcante da divulgação científica atual. Infelizmente, afirmá-la trata-se mais de um recurso retórico do que um verdadeiro 
sentimento presente no íntimo dos pesquisadores. Na prática, desconheço outra classe de estudiosos que esteja tão cheia de certezas quanto os cientistas estão. Esse é um ponto muito importante que já abordei em outras ocasiões e terei ainda que retornar a ele, inclusive quando comentar sobre os canais de divulgação científica na Internet.

Na página 39, Tyson diz que "os cosmólogos têm egos muito grandes". Afinal, "como não ter quando seu trabalho é deduzir o que fez o universo existir?". Parece difícil, para não dizer que é uma contradição completa, conciliar "egos muito grandes" com a suposta "humildade científica" da dúvida ${ }^{132}$. Este e todos os outros livros de divulgação, assim como os livros didáticos e as aulas proferidas por cientistas em geral, são coletâneas de dados absolutamente fabulosos, com precisão assombrosa, acerca de eventos em escalas inimagináveis e que ocorreram (ou ocorrerão) há (ou daqui) muitos bilhões de anos. E tudo isso é dito com suma segurança, como se não houvesse mais dúvida alguma sobre a veracidade de tal conhecimento, ainda que seja algo, por natureza, impossível de reproduzir e que apenas podemos inferir por meio da construção de modelos mais ou menos (in)adequados.

Diz Tyson (pp. 41-2):

"Enquanto as grandes galáxias contêm centenas de bilhões de estrelas, as galáxias anãs podem ter até mesmo 1 milhão, o que as torna 100 mil vezes mais difíceis de detectar. Não espanta que ainda estejam sendo descobertas debaixo dos nossos narizes."

Fica então a pergunta: quantas outras coisas mais serão descobertas "debaixo de nossos narizes"? A história da Ciência está repleta desses casos. Dos microrganismos, passando pela radiação eletromagnética não visível e chegando até a radioatividade, cada uma dessas descobertas mudou completamente os paradigmas vigentes. Teorias precisaram ser reformuladas praticamente do zero, e todo o conhecimento tido como certo até então perdeu grande parte, senão tudo, do seu valor. A qualquer momento novas descobertas desse tipo podem reduzir o nosso suposto conhecimento a um amontoado de escombros. O ensino e a divulgação da Ciência precisa de uma abordagem que enfatize essa possibilidade. Uma forma de

132 Sobre o mesmo "ego", Tyson diz na página 125: "abra as cortinas dos conflitos raciais, étnicos, religiosos, nacionais e culturais da sociedade e você encontrará o ego humano girando os botões e puxando as alavancas". O que poderíamos concluir disso, levando em conta o "ego muito grande" dos cosmólogos e da maioria dos cientistas em geral? 
fazer isso é, ao ensinar qualquer teoria, mas em especial as que estão na fronteira do nosso conhecimento (origem do Universo, origem da vida etc.), que deixe-se claro que tal conhecimento assim o é até o momento, de acordo com nossos melhores modelos atuais, e que ainda estamos buscando por mais evidências, e que tais evidências podem muito bem mostrar que estávamos fundamentalmente errados. Infelizmente, não é assim que é feito, nem por Tyson, nem por quase nenhum professor ou divulgador.

A seguinte citação de Tyson oferece excelente material para discussão (pp. 556, itálicos e [ ] meus):

"Céticos convictos podem comparar a matéria escura de agora com o hipotético e hoje finado 'éter' surgido no século XIX como o meio sem peso e transparente que permeava o vácuo espacial pelo qual a luz se movia. [...] Diferentemente das ondas sonoras, que consistem de vibrações do ar, as ondas luminosas se revelaram pacotes de energia autopropagados, não demandando qualquer ajuda. A ignorância sobre a matéria escura difere fundamentalmente da ignorância sobre o éter. O éter preenchia uma lacuna em nossa compreensão incompleta, ao passo que a existência da matéria escura não deriva de uma mera suposição [?], mas dos efeitos observados de sua gravidade sobre a matéria visível. Não estamos inventando a matéria escura do nada [!], em vez disso, deduzimos sua existência a partir de observações [!!!]. A matéria escura é tão real quanto os muitos exoplanetas descobertos em órbita de estrelas que não o Sol, descobertos apenas por intermédio de sua influência gravitacional sobre as estrelas anfitriões, e não de medições diretas de sua luz."

Para começar, embora modelos mais completos e matematizados para o éter tenham surgido apenas no século XIX, a ideia de uma substância-suporte para a propagação da luz foi proposta por Huygens ainda no século XVII, tornando a primeira afirmação de Tyson no mínimo imprecisa (e isso sem entrar no mérito do éter dos antigos gregos). O éter não era, e ainda não é, uma ideia tola. Ele não simplesmente "preenchia uma lacuna em nossa compreensão incompleta", mas era uma necessidade não só metafísica como também física; é a ideia de uma onda "autopropagada" que tenta eliminar o problema como Alexandre o Nó Górdio. Uma ondulação não é uma substância' ${ }^{133}$ : é um atributo de uma substância, necessitando dessa última para existir, tal como não existe "temperatura" ou "carga elétrica"

${ }^{133}$ Ver nota 71 da seção 1.9. 
separada de uma substância qualquer. Então ficamos com um dilema: ou os campos eletromagnéticos ondulantes são uma substância, ou são atributos de outra substância. Mas tudo indica que tais campos são meros conceitos físicos matematizados, como os vetores que representam forças ou os eixos de coordenadas cartesianas que representam o espaço, que nos auxiliam a responder perguntas, mas que não possuem existência física própria. Ficamos então inclinados a aceitar que os campos eletromagnéticos devem ser considerados como atributos de outra substância, aquela que é o sujeito do predicado "ondular" (Martins, 1993), quer chamemo-la de éter ou de qualquer outro nome.

Por incapacidade de detectar tal substância, que de fato deve ser muito diferente de tudo o que é conhecido (exatamente da mesma forma que a matéria escura o é), optamos por aceitar a tal da "autopropagação" de um atributo independente de uma substância, ideias que são inadmissíveis do ponto de vista lógico, ontológico e metafísico de uma Teoria de Substrato (e, por consequência, ainda que em geral os cientistas não concordem, é também fisicamente inadmissível). Somos doutrinados a aceitar isso nos cursos de graduação, assim como a ver o éter como uma ideia ridícula, sem nunca recebermos a explicação verdadeira, a não ser por professores realmente esclarecidos, de que o éter foi eliminado da Física por uma escolha epistemológica: a de não aceitar entidades não detectáveis em suas teorias. Essa decisão pode nos permitir avançar rapidamente em certo sentido, como de fato aconteceu, ao ignorarmos um problema que esteja fora de nosso alcance resolver. Mas isso não faz com que o problema desapareça. A questão da ontologia da luz continua muito mal explicada. Lembrando o que diziam Kuhn e Laudan, vemos que a Teoria da Relatividade é um perfeito exemplo de que o avanço da Ciência trás consigo não apenas ganhos para o conhecimento, mas também perdas: ao eliminar o éter, pudemos avançar muito na compreensão dos efeitos relativísticos, mas perdemos parte essencial da resposta acerca do que é a luz. Além disso, muito do que era indetectável no passado é perfeitamente detectável hoje. E muito do que é indetectável hoje poderá ser detectável amanhã. Dessa forma, é fora de propósito ridicularizar o éter enquanto se assume como muito certa a matéria escura.

De acordo com Tyson, a matéria escura "não foi inventada do nada" (o éter também não foi, como ele claramente sugere) mas é "deduzida [sic] a partir de 
observações" (o éter também é "deduzido [sic] de observações"134 de que toda onda observável precisa de um meio material de propagação), referindo-se às anomalias gravitacionais observadas em grandes escalas. Esse é, na realidade, um dos mais perfeitos exemplos do modus operandi verdadeiro dos cientistas; a matéria escura é uma hipótese ad hoc por excelência. Se a única propriedade da matéria escura que pode ser detectada é a sua suposta influência gravitacional, então a existência da matéria escura é indistinguível de um erro na Teoria da Relatividade Geral: temos tanta razão para afirmar uma coisa quanto temos para afirmar a outra. A anomalia gravitacional, em tese, deveria ter falseado a Relatividade Geral. Isso é o que os popperianos radicais e honestos diriam. Mas a realidade é outra: aceitar uma teoria como falseada sempre foi, e pelo visto sempre será, a última alternativa para o cientista. Da mesma forma como a anomalia observada na órbita de Mercúrio foi atribuída à existência de outro hipotético planeta ad hoc, as atuais anomalias são atribuídas à hipotética matéria escura. A matéria escura pode ser real ${ }^{135}$ ? Pode (Tyson afirma enfaticamente que ela é real), assim como Vulcano também podia ter sido, e tal como o éter ainda pode ser. Aliás, não me surpreenderia se em um futuro próximo a matéria escura fosse realmente detectada por outros meios, e que fosse descoberto que a ondulação dos campos eletromagnéticos ocorrem, justamente, na matéria escura. Bem cabe agora a seguinte citação do prof. Martins (2001, p. 125):

"De um modo geral, um cientista atual gosta de pensar que ele próprio é muito superior aos 'antigos', e por isso ele acredita com facilidade em quem Ihe diz que os pensadores que foram ultrapassados eram tolos, não tinham bons argumentos, não sabiam fazer ciência, e suas ideias apenas foram aceitas porque recebiam o apoio de religiosos estúpidos."

Em um aparente lapso, em que Tyson realmente parece vislumbrar o grande "oceano que ignoramos" da famosa citação de Newton, diz ele (p. 72):

"Daí meu pesadelo recorrente: será que nós também estamos perdendo algumas peças básicas do universo que antes existiam? Quais

\footnotetext{
134 O termo "deduzido de observações" é intrinsecamente equivocado: uma dedução é o ato racional de se inferir logicamente uma conclusão partindo de premissas válidas. Quando tiramos alguma conclusão de uma observação, o termo "dedução" não se aplica; neste caso, seria melhor falar em "indução".

${ }^{135}$ A afirmação de Tyson de que "a matéria escura é tão real quanto os muitos exoplanetas" e tudo o que se segue é um ótimo exemplo que pode ser utilizado, por exemplo, em sala de aula para se debater acerca do realismo ingênuo que impregna o imaginário dos cientistas e divulgadores de nosso tempo.
} 
partes de nossa história cósmica foram marcadas como 'acesso negado'? O que permanece ausente de nossas teorias e equações que deveria estar lá, fazendo com que busquemos respostas que talvez nunca vamos encontrar?"

Justamente. Mas isso não precisa ser um pesadelo: é apenas a crua realidade da validade de nosso conhecimento. Isso não é algo necessariamente ruim, mas simplesmente é como é. O nosso conhecimento, por mais limitado que seja, ainda tem nos servido, em termos materiais, melhor do que qualquer outra coisa já produzida. Não é depreciar a Ciência admitir que nosso conhecimento pode estar, e muito provavelmente está, errado. Isso porque o erro, assim como o acerto, não é total: segundo um realismo moderado, as teorias abandonadas tinham algo de real, algo que permanece nas teorias atuais, implícita ou explicitamente. Se uma teoria não fizesse nenhuma afirmação dotada de um mínimo fator de realidade, então ela não poderia descrever absolutamente nada do mundo. Porém, descrever determinado fenômeno é uma coisa (a chamada acomodação). Prever novos fenômenos é algo mais difícil. Dizer que "explicamos" o fenômeno ou que realmente sabemos do que estamos falando já é extrapolar a realidade do nosso real conhecimento. Recriar a origem da vida ou do Cosmo é algo muito mais delicado e é praticamente impossível discernir o que há de real, se é que há, nas afirmações que dizem respeito a esses temas. Ainda assim, não devemos cair no extremo de dizer que nossas teorias são absolutamente vazias de realidade e puramente uma ilusão da mente humana tentando decifrar o Cosmo. Por que, afinal, seria impossível para a mente humana decifrar uma ínfima parcela do Cosmo que seja, sendo a mente, ela mesma, parte do próprio Cosmo? A natureza da mente que decifra necessariamente possui uma intersecção com a natureza do Cosmo que é decifrado ${ }^{136}$. Isso já pode nos dar alguma mínima segurança quanto a nossa capacidade de conhecer alguma coisa. Mas é completamente ingênuo crer que qualquer uma de nossas teorias é mais do que essa dita ínfima parcela do mistério total; deveríamos nos abster de afirmar que realmente sabemos algo, acima de toda dúvida, acerca desse mistério. É difícil encontrar esse tipo de equilíbrio, tanto no ensino quanto na divulgação científica. Felizmente, encontrei algo assim no próximo livro que será comentado.

${ }^{136}$ Edgar Morin em seu O Método 3: O Conhecimento do Conhecimento (2005) oferece-nos um valioso ensaio a esse respeito. 


\subsection{2 - A Ilha do Conhecimento - Marcelo Gleiser - 2014}

Até o momento da escrita desta seção da dissertação (dez/2019), desconhecia por completo o trabalho de Marcelo Gleiser. Sabia que era Físico, brasileiro, atuante no exterior e que havia tido alguma participação na TV, mas nunca havia lido nada de sua autoria nem assistido nenhum programa em que ele aparecesse. O meu primeiro contato com a sua obra não foi, de certo, o mais favorável a ele: conheci-o através dos três severos artigos do prof. Martins em que um dos livros de Gleiser, o premiado A Dança do Universo (1997), é duramente criticado por certas passagens equivocadas ${ }^{137}$. Como primeira leitura, decidi optar por um trabalho mais recente. Lançado em 2014, quase duas décadas depois de A Dança, A llha do Conhecimento certamente deveria transmitir um avanço em maturidade por parte do autor. De fato, alguns dos erros apontados pelo prof. Martins do livro de 1997 foram aqui corrigidos. Outros foram apenas atenuados. Mas, sem dúvida, o que mais me chamou a atenção foi ter visto algumas das ideias que defendi nesse trabalho antecipadas por Gleiser em seu livro. A palavra que melhor define a posição de Gleiser, e que é uma concepção que também valorizo, é equilíbrio. O objetivo maior do livro é mostrar os limites do conhecimento científico. Embora seja um tema citado por outros autores, o normal é que isso seja feito de forma displicente: normalmente, afirmam que o conhecimento científico é limitado, para em seguida assegurar ao público de que suas teorias favoritas estão corretas e "comprovadas". Um dos motivos para isso, creio eu, é a crença de que uma excessiva ênfase nos limites da Ciência possa trazer algum demérito a ela (ou à profissão do cientista). Sobre isso, diz Gleiser (2014, p. 14):

"É importante deixar claro que expor os limites da ciência não implica, de forma alguma, apoiar o obscurantismo. Pelo contrário, esboço aqui uma autocrítica da ciência que, a meu ver, se faz extremamente necessária em uma época em que a arrogância e a especulação científica são propagadas sem qualquer controle. Ao descrever os limites das explicações científicas, minha intenção é proteger a ciência de ataques à sua integridade intelectual. Busco, também, mostrar como a ignorância, e não o conhecimento, é a mola propulsora da criatividade científica."

${ }^{137}$ Os três artigos foram utilizados como referência bibliográfica na presente dissertação, e são os dois de 1998 e o de 2000. 
Vê-se que o autor não atenua a questão dos limites do conhecimento, ao mesmo tempo em que deixa claro que tais limites não tiram o mérito da Ciência. Quanto a "proteger a ciência de ataques à sua integridade intelectual", entendo da seguinte forma: para o público em geral, e com muita razão (embora não toda a razão), a Ciência parece não realizar autocrítica. Fato: há consensos demais e debates de menos $^{138}$. Parecemos viver em uma época em que todos os cientistas concordam sobre todas as teorias ( $\mathrm{e}$, de fato, a esmagadora maioria dos cientistas realmente concorda totalmente sobre elas ${ }^{139}$ ). Se aqueles envolvidos mais intimamente com a Ciência, com o ensino e com a divulgação se ocupassem dos debates, da autocrítica, da contraposição de argumentos etc., as críticas vindas do público leigo alinhado com a anticiência seriam obsoletas. Todos os argumentos utilizados pelos movimentos anticiência já teriam sido expostos antes ao público leigo, e pelos próprios profissionais especializados. É de se esperar que, se os cientistas não criticarem suas teorias, alguém vai. E se esse alguém estiver mais afinado com o público por um meio qualquer, é a esse alguém que o público tenderá a dar ouvidos.

Como professor, procuro encarar de forma bastante crítica as teorias científicas, tanto em meus estudos pessoais quanto em minhas aulas. Mas, diferente daqueles que criticam para desmoralizar a Ciência, busco criticar com o objetivo descrito acima: em busca da realidade com relação à validade dos conhecimentos; em busca de tornar obsoleta qualquer crítica provinda de desinformados; em busca de remover algo da intransigência científica e aproximá-la de nossa inexorável natureza humana. Por exemplo, numa aula sobre gravitação, posso eu mesmo já expor todos os argumentos utilizados pelos terraplanistas que tentam descreditar o consenso científico. Posso mostrar aos alunos as motivações por trás dos argumentos, onde eles falham, como que os cientistas, ao longo dos séculos, foram superando tais concepções, quem foram os protagonistas envolvidos em tais debates etc. Tudo isso servirá de "vacina" contra os proponentes do terraplanismo: quando algum de meus alunos se deparar com alguém defendendo a Terra plana, devido ao

\footnotetext{
138 Deixo claro aqui que não me refiro à prática científica de fato, onde certamente existem muitas questões em debate, mas a como ela é exposta ao público.

139 Uma pesquisa realizada por Anderegg et. al. (2010) mostra que entre 97\% e 98\% dos especialistas estão de acordo com relação ao aquecimento global. Taxas similares são encontradas para praticamente todas as teorias modernas, da Relatividade à Evolução biológica.
} 
seu contato antecipado com todos os argumentos normalmente utilizados, ele próprio será capaz de identificar os erros e saberá diferenciar o fazer científico do fazer anticientífico. Será muito mais difícil um terraplanista convencer uma pessoa assim capacitada do que convencer alguém que apenas teve experiências intransigentes e acríticas com a Ciência.

Com relação à "arrogância e a especulação científica" que estão sendo "propagadas sem qualquer controle", imediatamente me veio em mente a figura de Stephen Hawking. De fato, apesar de Gleiser não citá-lo diretamente, é difícil não concluir que era sobre o livro $O$ Grande Projeto, do falecido cientista inglês, que ele se referia na seguinte passagem (p. 29):

"Mesmo que muitos cientistas argumentem que a física moderna - em particular a mecânica quântica - possa explicar a origem cósmica, o fato é que explicar a origem do Universo apenas através da ciência é um enorme desafio conceitual. Promulgar publicamente que a ciência hoje pode fazê-lo não só é incorreto e irresponsável como demonstra uma ignorância alarmante do que a ciência pode ou não fazer ou sobre como ela funciona."

Completa ele mais à frente (p. 44):

"[...] o desenvolvimento da cosmologia e da física quântica durante os séculos XX e XXI força muitos cientistas - ao menos aqueles com interesses em uma temática de caráter mais fundamental - a confrontar questões de natureza metafísica que ameaçam comprometer a 'confortável' separação entre ciência e filosofia. Infelizmente, a maioria dos cientistas que se manifesta publicamente sobre suas especulações metafísicas o fazem de forma superficial e muitas vezes incoerente, criando mais confusão e sensacionalismo do que conhecimento. Quando cosmólogos famosos pronunciam que 'a filosofia é inútil' ou que 'a cosmologia quântica prova que Deus não é necessário', apenas ajudam a piorar as coisas ${ }^{140 . "}$

Justamente. Acrescento a isso a defesa de que a tal "confortável" separação entre Ciência e Filosofia não existe realmente; a Ciência nasceu da Filosofia e ainda permanece como sendo um de seus ramos. Reconheço o quão polêmica é uma afirmação como essa e muitos protestariam prontamente frente a ela. Como argumentei ao longo desse trabalho, todas as teorias Científicas baseiam-se em princípios metafísicos (que são princípios filosóficos) e toda validade que tais teorias

140 Tais pronunciamentos são exatamente os que foram feitos em O Grande Projeto. 
presumam possuir é proveniente da Teoria do Conhecimento (ou seja, provém dos resultados obtidos pelos filósofos que trabalharam nessa área). Podemos encontrar uma defesa alternativa feita por Edgar Morin em seu O Método III (2015, p. 28):

"Pode-se e deve-se definir filosofia e ciência em função de dois polos opostos do pensamento: a reflexão e a especulação para a filosofia; a observação e a experiência para a ciência. Mas seria uma loucura crer que não há reflexão nem especulação na atividade científica, ou que a filosofia desdenha por princípio a observação e a experimentação. As características dominantes numa são dominadas na outra e vice-versa. Por isso, não há fronteira 'natural' entre elas. De resto, o século de ouro do desabrochar de uma e do nascimento da outra foi o século dos filósofos-cientistas (Galileu, Descartes, Pascal, Leibniz). De fato, como bem observou Popper, por mais separadas que estejam hoje, ciência e filosofia fazem parte da mesma tradição crítica, cuja perpetuação é indispensável à vida de ambas. Mesmo depois da disjunção entre ciência e filosofia, a comunicação nunca foi totalmente cortada, mas somente encurtada. Sempre houve reflexão filosófica sobre a ciência, renovada a cada geração de modo original (a filosofia analítica anglo-saxã sendo a mais recente expressão disso); sempre houve entre os filósofos o desejo de que a filosofia se torne 'saber do saber científico, a sua consciência de si'. Melhor ainda, as ciências mais duras suscitaram desde dentro um verdadeiro florescimento filosófico."

Por fim, diz Russell (Conhecimento Humano, 2018, p. 489):

"Tudo o que acreditamos conhecer sobre o mundo físico depende inteiramente da suposição de que existem leis causais. [...] A questão da justificação de nossa crença na causalidade pertence à teoria do conhecimento [...]."

Mas, se assim é, então a Ciência é impossível sem a Filosofia: a Ciência depende da causalidade, que por sua vez é assunto da Teoria do Conhecimento, que é, por excelência, uma nos núcleos do saber filosófico.

Os cientistas atuais podem escolher não estudar explicitamente Filosofia, embora estejam-na estudando, sem saberem, quando se debruçam sobre as teorias científicas. Como já dito anteriormente, nossos cientistas são formados na base do "cala a boca e calcula", orientados a não se questionarem sobre "o que é massa?" ou "o que é carga elétrica?", nem a questionar as interpretações-padrão da Relatividade ou da Mecânica Quântica. É dito a eles que essas questões "não fazem sentido", ou que é "impossível encontrar respostas para elas". Ignora-se que, até pouco tempo 
atrás, todos os maiores cientistas eram também filósofos.

O próprio Gleiser acaba incorrendo nessa visão de mundo quando afirma que (p. 63) "[...] no mundo quântico, querer ir além dos limites impostos pela incerteza não faz qualquer sentido". A visão predominante da atualidade é que o Princípio da Incerteza é mais do que um conceito teórico: é o reflexo de um aspecto fundamental e incontornável da Natureza. Se assumirmos que isso é verdade, então quer dizer que a humanidade foi de fato capaz de descobrir um conhecimento profundo e final acerca desse assunto. Ora, mas o próprio Gleiser, assim como muitos outros cientistas e filósofos afirmam que qualquer conhecimento não pode ser final: ele necessariamente é, no máximo, uma aproximação e uma simplificação da realidade última — esta considerada, por praticamente todos, incognoscível. A contradição é evidente: se aceitarmos a Incerteza Quântica como a última palavra no assunto, então estamos dizendo que a Ciência é de fato capaz de revelar os grandes mistérios da Natureza. Mas para sermos coerentes com a posição de que nenhum conhecimento é final, teremos que ser como Einstein e negar que tal abordagem seja a dita última palavra.

Os fenômenos quânticos se encontram por trás da realidade "clássica" de nosso cotidiano. Quem pode dizer que não há, e que não faz sentido procurar, uma outra gama de fenômenos que esteja por trás dos fenômenos quânticos? Afirmar que "não faz sentido" é fechar as portas para a pesquisa de toda uma grande área de potenciais descobrimentos. Procurar por uma partícula mais rápida do que a luz, por uma máquina de movimento perpétuo ou por uma resolução para a Incerteza Quântica parece uma completa tolice frente às teorias atuais. Mas há dois pontos a serem considerados a esse respeito: primeiro, se assumirmos que de fato essas buscas são tolices, então não podemos afirmar jamais que outros tantos mistérios não serão resolvidos no futuro, já que fomos capazes de resolver esses; segundo, isso quer dizer que a Ciência não está aberta a mudanças em certos aspectos de seus fundamentos. Essa segunda consequência é particularmente nociva: pode ser que, agora mesmo, estejamos atrasando o nosso progresso unicamente por considerarmos certas pesquisas como "destituídas de sentido". Não é demais citar o fato de que uma pesquisa pode trazer resultados inusitados, completamente imprevistos, mesmo que o objetivo inicial não tenha sido atingido. Sobre todo esse assunto, o prof. Martins expôs com grande clareza da seguinte maneira (1993, p. 18, [ ] meus): 
"Pode-se supor que as chamadas 'partículas elementares' são de fato 'elementares' (isto é, sem partes, indecomponíveis) ou que é possível descobrir sua constituição. A primeira atitude é conservadora e limita a pesquisa àquilo que já é conhecido. A segunda atitude é capaz de estimular a pesquisa do desconhecido e pode, portanto, levar mais facilmente ao progresso da ciência. Supor que nada existe no universo além do que já conhecemos, é uma crença que desestimula a pesquisa. Uma dessas formas é exatamente a negação do inobservável - e a negação do éter, em particular [ou a de um comportamento quântico limitado pelo Princípio da Incerteza etc.]. Se supomos que existe o éter, abre-se um novo campo de indagações e de pesquisa; se supomos que, ao retirar tudo o que percebemos de um recipiente, lá não resta nada, não há o que investigar nesse local. Assim, como concepção diretriz para a pesquisa, é preferível supor a existência do éter [ou a de que o Princípio da Incerteza pode ser superado etc.] do que negá-lo."

Com relação a isso, o próprio Popper demonstra n'A Lógica (capítulo IX) que "a existência de limites de precisão atingível, asseverada por Heisenberg [não é] uma consequência lógica, deduzível a partir de fórmulas da teoria", mas antes "um pressuposto distinto ou adicional". Completa dizendo que "medidas mais precisas não apenas são compatíveis com a teoria quântica, mas é até mesmo possível descrever experimentos imaginários que demonstram a procedência de medidas exatas". É claro que a palavra de Popper não é a última, mas de nossos atuais cientistas e filósofos também não são. Se alguns cientistas creem que tal ou qual campo de pesquisa não faz sentido ser explorado, então eles deveriam tão somente optar por outros campos, abstendo-se de fechar as portas, literalmente ou moralmente, da pesquisa aos demais interessados.

De toda forma, voltando aos comentários acerca do livro de Marcelo Gleiser, em diversos momentos ele aponta para aspectos comumente ignorados do progresso científico. Ele diz, por exemplo (p. 91), que "quando uma ideia atraente começa a falhar, hipóteses cada vez mais estranhas e excêntricas são pospostas para salvá-las [as ditas hipóteses ad hoc]". Esse continua sendo um ponto delicado: é muito fácil nos inclinarmos contra o uso das hipóteses ad hoc e, de fato, é um procedimento um tanto quanto insatisfatório, uma vez que não acrescenta ao nosso conhecimento real da Natureza. Por outro lado, parece ser esse o procedimento padrão dos cientistas: 
buscar salvar, a todo custo, suas teorias preferidas ${ }^{141}$. Isso revela mais sobre o caráter humano do que sobre a Natureza em si. Gleiser nota isso quando afirma que (p. 92) "cientistas criam hipóteses que defendem arduamente" e que "assim deve ser, já que, quanto mais promissora uma ideia, mais paixão incita". Ignorar que esse impulso presente em toda atividade humana esteja também presente no cientista enquanto este faz ciência é, no mínimo, insensato. Settle (1971) afirma que é quase uma falácia de divisão (quando atribuímos às partes as características do todo) crer que cada cientista, individualmente falando, age com uma mente puramente crítica, uma vez que a presumida racionalidade e atitude crítica são mais características da Ciência como instituição, como atividade coletiva, do que características das partes elementares envolvidas (os cientistas).

Um outro comentário interessante ressalta um erro comum de muitos dos cientistas, divulgadores e professores: acreditar que a correspondência com os dados empíricos é uma prova de que a teoria é "correta", ou ainda que ela, de fato, descreve "a Natureza tal como ela é". Diz Gleiser (p. 92):

"Uma explicação pode até descrever os dados satisfatoriamente [...] mesmo sem ter qualquer ligação com a realidade. Os epiciclos, por exemplo, descrevem bem os movimentos celestes, mesmo se completamente artificiais; o flogisto e, mais ainda, o calórico descreviam bem a combustão e o fluxo de calor, mesmo se inexistentes."

O que nos leva ao questionamento: quantas outras grandezas e entidades são atualmente medidas e tratadas como se existissem realmente acabarão, por fim, consideradas como obsoletas e até inexistentes?

Por fim, como último comentário ${ }^{142}$, na p. 117, Gleiser aponta o fato de que os conceitos de "instantâneo" e "eterno", tão presentes em descrições físicas, são e sempre serão metafísicos. Afinal, não podemos dizer, por meio de teste empírico, que um evento qualquer não durou qualquer intervalo de tempo (como a absorção de um fóton por um elétron), devido ao fato de que qualquer instrumento de medida, por

${ }^{141}$ Laudan, por exemplo, no capítulo 3 de seu livro O Progresso e Seus Problemas (Ed. Unesp, 2011), originalmente publicado em 1977, faz uma defesa aberta das hipóteses ad hoc, afirmando que, se elas forem úteis para resolver problemas com os quais os cientistas se deparam, então não há nada de intrinsecamente ruim em sua adoção.

142 O livro é longo e bastante informativo. Infelizmente, não há mais muito espaço para tratar de seus interessantes pontos no presente trabalho, mas recomendo a leitura. Dentre todos os livros analisados, foi o de leitura mais proveitosa. 
melhor que seja, sempre possui um intervalo-limite mínimo de medição. Com relação ao que é eterno (por exemplo, o movimento retilíneo e uniforme de uma partícula devido à sua inércia), mesmo que fosse possível isolar tal partícula completamente de todas as forças externas (ou mantê-la sempre com força resultante nula), nunca teríamos espaço e nem tempo eternos disponíveis para testar se a partícula realmente não terá seu estado de movimento alterado (toda medição empírica, necessariamente, ocorre dentro de um intervalo de tempo e uma região determinada do espaço). Assim, Gleiser fornece mais exemplos, além de tantos outros que dei ao longo desta dissertação, da onipresença da Metafísica em meio a conceitos considerados físicos e supostamente "emancipados" da Filosofia.

\section{5 - Sobre a divulgação científica na Era da Internet}

A partir do momento em que a internet começou a se expandir e a se tornar mais acessível, as principais formas de obtenção de informação eram textuais: sites de revistas e jornais, fóruns e blogs. Mas sendo o hábito de leitura algo naturalmente restrito a uma relativamente pequena parcela da população, parece razoável a suposição de que a maioria dos "leitores de internet" já eram leitores antes dela. Assim, nesse primeiro período, a internet não foi um grande impulsionador da divulgação científica. Isso começou a mudar com o advento do streaming. Surgiu então a oportunidade de se obter informação de uma maneira mais simples, mais agradável para a maioria, através de vídeos. Surgiram plataformas de grande popularidade, como a Netflix e, principalmente, o YouTube. No primeiro, podemos encontrar diversos documentários científicos, alguns que já eram exibidos em canais pagos da televisão (com um preço muito mais elevado do que o cobrado pela Netflix), e alguns originais da própria plataforma. Embora não seja o principal foco da plataforma (e, em geral, nem de seus assinantes), o volume de conteúdo disponível pelo relativamente baixo custo é algo realmente notável. No caso do YouTube, a situação foi ainda mais impactante. Nessa plataforma, estão atualmente disponibilizadas muitas centenas, talvez milhares, de documentários científicos gratuitos, provenientes da própria plataforma, ou de canais televisivos que têm seus 
programas postados no YouTube, ou ainda de produtores independentes que possuem seus próprios canais. Esse último caso é o mais importante para o propósito desta dissertação.

Com a possibilidade de qualquer pessoa com uma câmera e acesso à internet produzirem conteúdo, surgiu todo tipo de canal, abordando todo tipo de assunto e das mais diversas maneiras. Embora com uma participação menor do que o ramo do entretenimento, os canais de educação possuem um volume de conteúdo enorme. Há inúmeros canais de videoaulas que cobrem totalmente, e gratuitamente, o conteúdo do Ensino Médio. $O$ aluno pode assistir quando quiser, e quantas vezes precisar, todas as aulas em que tiver interesse. Muitos dos professores que têm seus canais também dão suporte com resolução de dúvidas. Mesmo outras pessoas que acompanham aquele conteúdo podem auxiliar a resolver dúvidas através das seções de comentários que quase todos os vídeos disponibilizam. O meu foco, entretanto, estará nos canais especificamente voltados à divulgação científica em si, e não em aulas. Em particular, comentarei alguns pontos de vídeos dos quatro maiores canais de divulgação do Brasil: Nerdologia, Ciência Todo Dia, Canal do Schwarza e Canal do Pirula.

Deixo o aviso de que os comentários que farei dizem respeito única e exclusivamente aos vídeos que de fato assisti, e que podem não ser válidos aos demais vídeos, os quais, em sua maioria, não assisti. Também não tenho a intenção de ofender ou atacar ninguém, mas tão somente fazer apontamentos de ordem pedagógica, epistemológica e conceitual. Todos os números e dados estatísticos foram retirados do site socialblade.com, onde tais informações se encontram públicas. As consultas dos números foram realizadas nos meses de dezembro de 2019 e janeiro de 2020, época em que esta seção foi escrita. Será dada, para cada canal, uma visão geral e, em seguida, farei breves (espero) comentários acerca de um ou dois vídeos de cada um. Salvo exceções, os comentários são sobre trechos em que o divulgador enfatiza os elementos de Filosofia da Ciência abordados nos dois primeiros capítulos desta dissertação. Será, no final das contas, algo muito similar ao que foi realizado com os livros de divulgação.

\subsection{1 - Canal Nerdologia}


Este é o maior canal de divulgação científica do Brasil, tendo sua origem em 2010 e contando atualmente com mais de 2,6 milhões de inscrições. Só no mês de dezembro de 2019, o canal obteve mais de 4 milhões de visualizações, sendo o canal de Ciência em língua portuguesa mais assistido do mundo. Seu apresentador principal é o biólogo e colunista Atila lamarino, doutor pela Universidade de São Paulo; depois, o canal incorporou o historiador Filipe Figueiredo, apresentando episódios com temas históricos. Um dos conceitos centrais do canal era o de tentar explicar cientificamente fenômenos encontrados na ficção (tais como os poderes dos super-heróis). Ao longo do tempo, foram surgindo e se tornando cada vez mais comuns vídeos com temas exclusivamente científicos. Poucos deles tratam do tema específico da Natureza da Ciência, estando mais centrados em divulgar conceitos básicos e descobertas recentes nos diversos ramos da Ciência e da tecnologia.

Os vídeos contam com uma sofisticada produção gráfica, contando com desenhos, animações, cenas recortadas de filmes e séries, dentre outros recursos. Livros e artigos são frequentemente citados e recomendados, além de serem respondidas, ao final de cada vídeo, diversas questões deixadas por espectadores na seção de comentários dos vídeos anteriores. Felizmente, encontrei um vídeo em que a Natureza da Ciência é abordada de maneira contundente, e foi ele o escolhido para a análise. O número de visualizações também foi fator crucial para a escolha: centenas de milhares de pessoas receberam o conteúdo do vídeo, sendo diretamente impactadas pela visão de Ciência ali exposta. Tamanho número e impacto não podem ser menosprezados. Esse vídeo servirá de exemplo concreto sobre como a Ciência tem sido apresentada ao grande público por meio da internet. É importante ressaltar que não se tratam de casos isolados: são, em realidade, exemplos que representam muito da divulgação científica atual. Segue comentários acerca do vídeo selecionado.

Uma questão de fé - dur.: 9min55s - publicado em 13 de jul. de 2017 e atualmente (dez/2019) acumula mais de 630 mil de visualizações.

O apresentador diz, logo no início aos 15s de vídeo, que "hoje veremos até onde acreditar na Ciência é uma questão de fé". Vejo como um tema muito importante, tendo em vista afirmações corriqueiras de que Ciência e fé são completamente incompatíveis (não me refiro somente à fé religiosa, como expliquei anteriormente). Aos 25s, Atila diz que... 
"Quando falamos de relatividade, matéria escura ou mesmo evolução, é comum ouvir que para cientistas acreditarem nessas coisas precisam ter muita fé. E precisamos mesmo! Mas não é bem do tipo que você está pensando. Religiosidade e fé são uma parte importante de como interagimos com o mundo e podem ser fundamentais para a sociedade humana. Sem falar dos benefícios pessoais, já que pessoas religiosas são menos ansiosas e mais felizes, mesmo em situações estressantes."

Aqui vemos um diferencial importante quando comparamos com outros meios de divulgação que resolvem falar de religião: o autor trata com respeito a religiosidade alheia, dizendo que a fé religiosa não é do mesmo tipo que a fé que os cientistas depositam em suas teorias, mas que não necessariamente se opõem.

Em 2m11s, o apresentador cita o autor Yuval Noah Harari, que em seu livro best-seller Sapiens, afirma que "o que difere a ciência de outras formas de conhecimento é a habilidade de admitir ignorância". Segundos depois, tentando explicar essa afirmação, o apresentador diz que...

"Quando falamos do Big Bang, estamos dizendo que a nossa melhor explicação para a origem do Universo é que ele surgiu e vem se expandindo há quase 14 bilhões de anos e que não fazemos ideia do porquê, ou do que havia antes, se é que havia um antes."

Ao dizer que "não fazemos ideia" e tudo o que se segue, Atila reforça essa noção de "habilidade de admitir a ignorância". Com a citação de Harari, o apresentador confirma o que diz Zamboni (2001) e também Moura (2001): estas últimas pesquisadoras notam o quão comum, na divulgação científica, é o uso de citações de autoridades para embasar posições impactantes; infelizmente, nesse caso, a citação impacta por sua presunção.

Em primeiro lugar, não há nada que indique ser a Ciência a única detentora da "habilidade de admitir a ignorância". Ao fazermos perguntas sobre os mais diversos temas, não necessariamente científicos, para uma pessoa qualquer, sempre será possível encontrar uma pergunta para qual a pessoa terá que admitir não saber a resposta. Em particular, a Filosofia não afirma saber tudo (muito pelo contrário, é da Filosofia o mérito da descoberta dos limites de conhecimento, e não da Ciência). Como comentei anteriormente, parece que nenhum outro grupo de estudiosos está mais cheio de certezas do que os cientistas. $O$ curioso é que, no exato momento em que afirma isso, o vídeo em questão faz uma referência em forma de trocadilho com 
o filósofo Sócrates, colocando a imagem do ex-jogador Sócrates e um balão com a fala "Só sei que nada sei"! Um filósofo! Mesmo afirmando que não sabemos muitas das coisas importantes referentes ao Big Bang, a própria afirmação, realizada de maneira categórica, de que o Universo "surgiu e vem se expandindo há quase 14 bilhões de anos" (o vídeo mostra o número mais preciso "13,8"), acaba soando estranha e não parece refletir a suposta "humildade" científica citada.

Em 3m12s, há um erro de edição, onde surge a imagem da fórmula da Gravitação Universal de Newton descrita como "Fórmula do Movimento", enquanto que as verdadeiras fórmulas do movimento são descritas como sendo da Gravitação Universal. Esse erro foi notado por alguns espectadores, que alertaram sobre isso na seção de comentários do vídeo.

A fé característica da Ciência, anunciada no título e no início do vídeo, é explicada em $4 \mathrm{~m} 12$, quando é dito que os cientistas de hoje, muito especializados em uma determinada área, precisam acreditar que "o que já foi feito antes [e também em outras áreas] era sólido". Mais tarde, em $5 \mathrm{m05s}$, inclui também a fé na "competência [dos pares] e no procedimento", assim como nos "métodos de análise". De fato é assim. Mas também é necessário incluir na "lista de artigos de fé científicos" uma enorme gama de pressupostos dos quais não é possível ter prova empírica de nenhuma espécie, mas apenas serem assumidos como verdadeiros a priorit43. E são eles os axiomas fundamentais, desde os princípios metafísicos primeiros (Causalidade, Uniformidade), passando por princípios metafísicos de menor nível (como o da Seleção Natural), e chegando até os postulados específicos de cada teoria. Como último exemplo, sem entrar em detalhes, já muito explorados em todo o texto da dissertação, para a pesquisa Científica acontecer é requisito indispensável ter fé de que encontraremos as respostas que buscamos. Conforme passagem já citada anteriormente, lembremo-nos de Popper (2013, p. 277) afirmando aberta e honestamente que compartilha da fé metafísica no princípio da Uniformidade da Natureza.

Mas, deve-se notar, a fé neste caso em particular está embasada em um longo

${ }^{143}$ É evidente que essa é apenas uma das concepções possíveis, e que há filósofos críticos sobre se realmente existe algo que possa ser assumido a priori. Mas, se nada pode ser assumido a priori, a situação é ainda mais difícil para aqueles que creem na validade do conhecimento científico, pois solapa uma das fontes de conhecimento que, se fosse legítima, nos concederia conhecimentos de base realmente verdadeiros e indubitáveis. Sem algo aceito a priori, a Ciência seria impossível. 
histórico de observações empíricas, tal como já era defendido por Hume. É verdade que o sol pode não nascer amanhã. Mas temos um sentimento psicológico de convicção tão grande de que ele irá, de fato, nascer (como o fez, no mínimo, ao longo de toda a história registrada), que nem levamos em consideração a possibilidade contrária. Mas é essa mesma fé, em linhas gerais, que está presente nos intentos dos cientistas em busca das respostas que, afinal, não temos como ter certeza de que realmente existem.

Continuando com o vídeo, por volta de $5 \mathrm{~m} 50 \mathrm{~s}$, é dada uma importante ênfase sobre a possibilidade de fraude científica, relatando um caso real, e na importância de se reproduzir os resultados em Ciência. Porém, em 6m22s, após a supracitada afirmação de que a Ciência é o nosso "primeiro conhecimento universal", diz o apresentador:

"Como só afirmações testáveis e testadas são incorporadas no conhecimento científico, as mesmas revelações por Newton ou Darwin podiam ser feitas por outras pessoas, e foram [!]. Em um desastre, como o da Biblioteca de Alexandria, poesias e obras de ficção são perdidas para sempre, já que ninguém consegue recriar o que os autores fizeram. Mas no caso da Ciência, mesmo que perdêssemos tudo o que aprendemos até hoje, redescobriríamos as mesmas fórmulas do movimento e a mesma data para a origem do Universo [!!!]."

Esse trecho é tão problemático que custaria muito espaço para que todos os pontos fossem devidamente comentados aqui. Farei alguns comentários referentes ao trecho anterior ao sinal [!]. Para começar, não só afirmações testáveis e testadas são incorporadas ao conhecimento científico, e isso é um dos pontos mais elementares da Teoria do Conhecimento. O conhecimento científico é fundamentalmente teórico. Toda teoria tem sua origem em axiomas que, por definição, não são "testáveis" e, portanto, nunca poderiam ter sido "testados". São desses axiomas não-testáveis que derivamos os enunciados ou proposições empíricas, esses sim testáveis, mas que podem ou não terem sido testados antes de sua incorporação ao conhecimento científico. Muitas teorias foram aceitas muito antes de seus enunciados empíricos terem sido testados (e, certamente, antes de terem seus axiomas testados, uma vez que tais testes são impossíveis). A própria Segunda Lei de Newton é um exemplo disso: o seu primeiro teste empírico decisivo veio apenas com a Máquina de Atwood (Kuhn, 2012, p. 92), quase um século depois da formulação 
publicada nos Principia.

Sobre outras pessoas que descobriram "o mesmo" que Darwin e Newton, suponho que ele se referia, respectivamente, a Wallace (cuja teoria evolutiva é divulgada como quase idêntica a de Darwin ${ }^{144}$ ) e Hooke, Wren e Halley (que haviam descoberto independentemente a "Lei do Inverso Quadrado" da Gravitação Universal ${ }^{145}$ ). De qualquer forma, em ambos os casos, é perigoso e forçoso dizer que "chegaram às mesmas revelações". É perigoso por que dá a entender que existe uma única possível interpretação do mundo, apenas esperando que o próximo gênio a descubra e a revele para a humanidade; e se existe apenas uma interpretação, a qual todos os cientistas tendem a convergir, quer dizer então que esses cientistas que de fato convergiram chegaram até a última palavra referente ao assunto — onde fica então a "humildade" da dúvida e a aceitação de que teorias podem mudar com o tempo? A contradição é evidente: se existe apenas uma explicação correta para um fenômeno, ao ser descoberta ela se tornaria eternamente fixada e jamais mudaria, implodindo por completo a ideia de uma Ciência dinâmica.

Além disso, o dito é forçoso porque esconde várias informações que, se levadas em conta, não autoriza a conclusão obtida: havia, sim, divergências entre Wallace e Darwin (ver Kutschera, 2003), e onde eles chegaram às mesmas conclusões é devido ao fato de terem partido das mesmas premissas ${ }^{146}$ (como a teoria de Malthus sobre o limite do crescimento populacional), e até das mesmas análises (Wallace inclusive utilizou muitos dados que obtinha de suas correspondências com

\footnotetext{
${ }^{144} \mathrm{O}$ erro baseia-se em afirmações feitas pelo próprio Darwin e por ambos os trabalhos terem sido apresentados simultaneamente, com a ajuda de outros respeitáveis cientistas, como Charles Lyell. A leitura pormenorizada de ambas as publicações, no entanto, revela que havia pontos de divergência importantes o suficiente para não permitir a afirmação de que ambos chegaram à mesma teoria (considerada como um todo). O maior prejudicado com essa afirmação é o legado do próprio Wallace, que normalmente é relegado ao segundo plano sem ter o devido reconhecimento por suas ideias originais que Darwin precisou incorporar em sua própria teoria. Ver referência à frente.

145 Ver Martins, 1998a, p. 254.

${ }^{146} \mathrm{O}$ estudo da história da Teoria da Evolução revela que havia um grande número de explicações alternativas para os mesmos dados disponíveis aos naturalistas da época. O próprio Darwin comenta sobre algumas dessas diversas visões n'A Origem das Espécies. Esse fato não permite sustentar a ideia de que a Evolução estava ali, apenas esperando para ser descoberta, e que os cientistas iriam convergir a ela mais cedo ou mais tarde. Darwin e Wallace convergiram em certos aspectos justamente pela aceitação prévia das mesmas premissas; mas outros cientistas, partindo de premissas diferentes, chegariam (e chegaram, e possivelmente chegarão) a outras conclusões que, naturalmente, poderiam (e poderão) ser igualmente válidas.
} 
Darwin); da mesma forma, Hooke, Wren e Halley apenas chegaram na "Lei do Inverso Quadrado", e não em muitas outras conclusões que foram originais do próprio Newton. Mas, nesse último caso, a questão é ainda mais elementar: a "Lei do Inverso Quadrado" é matematicamente deduzida das Leis de Kepler — ou seja, eles não poderiam ter chegado a nenhuma outra conclusão, não por terem revelado "a verdade" da natureza, mas por uma simples regra básica de lógica (que, como sabemos, é uma disciplina desconhecida da maioria dos cientistas de hoje): de uma conjunção de premissas tomadas como verdadeiras, existe apenas um conjunto deduzível de conclusões verdadeiras. O desafio maior foi cumprido por Kepler, que foi quem formulou as premissas — as suas Leis; partindo delas, não existe outro conjunto deduzível de conclusões verdadeiras. Se Kepler tivesse errado e suas premissas fossem falsas, mas tomadas como verdadeiras pelos cientistas citados, todos também teriam chegado às mesmas conclusões - no caso, conclusões falsas.

Da mesma maneira, partindo dos mesmos axiomas geométricos de Euclides, tomados como verdadeiros a priori, qualquer matemático inteligente seria capaz de deduzir exatamente as mesmas conclusões que definem a geometria euclidiana. Devido a esse unidirecionamento de conclusões possíveis, deduções matemáticas são a parte menor do trabalho científico; a parte principal é a junção original de conceitos, com a criação de proposições inusitadas, altamente improváveis e que, no entanto, sobrevivem aos testes, ao mesmo tempo em que respondem as questões cujas respostas são de nosso mais alto interesse. Conclusão: sendo as grandes contribuições científicas de Newton justamente essas suas proposições originais, e não as deduções que qualquer matemático, na posse das Leis de Kepler, poderia ter produzido, não podemos afirmar que outros chegaram (ou chegariam) às mesmas proposições originais que ele chegou, similarmente como não podemos dizer que, não fosse Beethoven, outros teriam composto suas sinfonias. Aliás, Einstein chegou a uma explicação totalmente diferente (de fato, incomensurável) da explicação de Newton para a gravidade. Como isso é possível, se a Ciência supostamente deveria revelar uma "explicação única" para a Natureza, de forma que todos os pesquisadores convergiriam, cedo ou tarde, para tal explicação? Não vejo como como contornar esse argumento.

Esse tipo de discussão costuma estar muito além do alcance de um vídeo comum de divulgação, ou mesmo de aulas presenciais mais sofisticadas no Ensino 
Médio. Mas pode-se notar a imensa falta que faz uma formação mais filosófica quando notamos a grande defasagem de entendimento que o público em geral, ou mesmo cientistas e professores, possuem sobre a Natureza da Ciência.

\subsection{2 - Canal Ciência Todo Dia}

Este é um canal de divulgação que pertence e é apresentado por Pedro Loos e conta com aproximadamente 1,52 milhões de inscritos. Durante o ano de 2019 (o canal existe desde 2012), foi o canal de divulgação científica brasileiro que mais cresceu, ganhando cerca de 480 mil inscritos durante o período, e tornando-se o segundo maior canal de divulgação científica do país. No mês de dezembro de 2019, o canal obteve mais de 2,3 milhões de visualizações em seus vídeos. Esses números revelam um grande alcance, senão também uma grande influência ao público que o acompanha.

O apresentador é bacharel em Física formado pela UFSC. Possui grande carisma e notável didática, de acordo com muitos dos comentários públicos deixados em seus vídeos. Seus vídeos contam com produções gráficas (animações) que, em geral (mas nem sempre, como veremos), são boas e ajudam a explicar o conteúdo abordado. O canal evita temas polêmicos e conteúdo de opinião, focando em explicar conceitos científicos, especialmente da Física. O tema Natureza da Ciência é tratado rara e pontualmente, não sendo o objetivo do canal uma maior exploração nesse terreno. Segue comentários acerca dos dois vídeos selecionados.

A História da Velocidade da Luz - dur.: 13min22s - publicado em 2 de fev. de 2019 e atualmente (dez/2019) acumula mais de 1,1 milhões de visualizações.

A grande popularidade e o fato de tratar diretamente de história da Ciência foi o principal motivo da escolha desse vídeo. Em geral, o vídeo é bom e oferece explicações relativamente simples de se compreender (Física bem explicada quase nunca é realmente simples de se compreender), porém com alguns erros que devem ser levados em conta. Esses erros revelam uma dificuldade comum em divulgação científica: a excessiva simplificação, às vezes, leva a equívocos conceituais e, consequentemente, conduzem o público a uma compreensão errônea.

No tempo de $8 \min 15$, o apresentador comete um dos erros mais comuns quando o tema é história da Eletrodinâmica e da Relatividade, afirmando que "foi na 
tentativa de provar que o éter existia que dois físicos, Michelson e Morley, fizeram uma das descobertas mais importantes e interessantes da Física: o éter não existe". Esse tema já foi abordado em uma seção anterior, justamente por se tratar de um erro comum. Em resumo, há pelo menos dois pontos equivocados na afirmação. Um deles é historiográfico: Michelson e Morley não estavam tentando "provar que o éter existia"147. A existência do éter era dada como certa e não estava em questão (sem aceitar a existência do éter, a própria configuração experimental não faria sentido e não teria sido proposta). O que eles estavam tentando medir era a velocidade da Terra com relação ao éter e, para tal, utilizaram a luz - que se propagaria no éter com a velocidade " $c$ ", já muito bem conhecida. A partir da diferença na velocidade da luz encontrada em posições (e, evidentemente, momentos) diferentes da órbita da Terra ao redor do Sol, eles calculariam via simples relatividade galileana a velocidade da Terra com relação ao éter. Nenhuma diferença foi encontrada, o que poderia, e de fato pôde, conduzir a uma série de conclusões das mais diversas, muitas ainda compatíveis com o éter. E é aqui que entra o segundo erro da afirmação, que é um erro epistemológico: nenhum experimento é capaz de provar que algo não existe. $\mathrm{A}$ solução proposta por Einstein e aceita pela comunidade científica foi tão somente a de não levar em consideração o éter, uma substância inobservável, considerando-o como desnecessário para explicar os fenômenos eletrodinâmicos (e, logo depois, relativísticos) observáveis. Em resumo, foi uma decisão epistemológica de abandonar o interesse pela causa e focar unicamente em seus efeitos.

Compreendo os prováveis motivos que levaram o apresentador a se expressar dessa maneira. Normalmente, é assim que a história da Relatividade é contada. O éter é normalmente visto como uma ideia tola e a decisão de Einstein é vista como uma ideia genial. Para não entrar em pormenores, é então dito simplória e falsamente que, através do experimento de Michelson e Morley e também da Teoria da Relatividade, "foi provado que o éter não existe". Mas, como já explicado, a concepção é errônea e foi, somente nesse vídeo, propagada para mais de 1 milhão de espectadores (supondo, razoavelmente, que cada um tenha assistido o vídeo uma única vez).

No tempo de 10min44s, outro equívoco é cometido: é dito que Einstein "postulou que a velocidade da luz não depende da velocidade da fonte". A mecânica

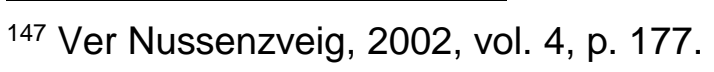


ondulatória clássica já estabelecia que a velocidade de uma onda não depende da velocidade da fonte, mas da velocidade do observador externo com relação à onda em si. O vídeo em questão ainda erra colocando uma animação de um automóvel lançando uma bolinha para frente, de forma que a velocidade da bolinha com relação ao solo será a soma da velocidade do carro com relação ao solo mais a velocidade da bolinha com relação ao automóvel. Isso está correto e corresponde à relatividade galileana clássica. O erro está no fato de que uma onda não se comporta como a bolinha: como já dito, sua velocidade de propagação independe da velocidade da fonte.

Um exemplo concreto é que, caso a velocidade da onda dependesse da fonte, não existiria a "quebra da barreira do som" por jatos devidamente denominados de supersônicos. Suponhamos que um jato como esse esteja viajando com velocidade $v$ com relação ao solo (tomado como nosso referencial). Um som qualquer emitido por ele viaja com velocidade $v_{s}$ que independe totalmente de $v$. Se assim não fosse, e o som se comportasse como a bolinha da animação, a velocidade do som emitido seria sempre $v+v_{s}$ (para um observador em repouso nesse referencial). Ou seja, seria tão mais veloz quanto mais veloz estivesse o jato. $O$ jato, portanto, jamais poderia ultrapassar a velocidade do som, que seria absolutamente inalcançável. É justamente por $v$ e $v_{s}$ serem independentes que eventualmente $v$ pode se igualar e até mesmo superar $v_{s}$, chegando a valores supersônicos. O erro cometido no vídeo, pela fala e também pela animação mostrada, foi um descuido que poderia ter sido evitado.

O que Einstein postulou é que a velocidade da luz será sempre medida com o mesmo valor por um medidor qualquer. Não é exato dizer que Einstein postulou algo que já era conhecido e facilmente demonstrado pelas teorias ondulatórias clássicas. O grande avanço da Teoria da Relatividade foi fixar o mesmo resultado para qualquer observador - um conceito não tão simples de ser explicado, mas que não podemos abrir mão de tentar explicar, caso queiramos expor corretamente a Relatividade Restrita e como se deu a evolução conceitual da Física ${ }^{148}$. O apresentador acaba expandindo a explicação até chegar a esse ponto, mas isso não anula o erro contido na frase supracitada, e nem na animação, que podem influenciar negativamente na compreensão do público acerca do assunto.

${ }_{148}$ Para mais, ver Martins, 1998b, pp. 266-8. 
Como ímãs funcionam? (Ímãs Explicados) — dur.: 8min27s - publicado em 28 de dez. de 2019 e atualmente (dez/2019) acumula mais de 150 mil visualizações.

Esse é o mais recente vídeo publicado pelo canal no momento em que escrevo esta dissertação, e por isso foi escolhido para análise. Ele faz parte de uma série denominada "Explicados" em que o autor escolhe temas notáveis (ímãs, as leis de Newton, o Big Bang etc.) e dedica o vídeo a explicá-los. Nesse vídeo em particular, há uma série de erros conceituais que tratarei de expor a seguir.

Ao tempo de $2 \mathrm{~min} 43 \mathrm{~s}$, ao tentar explicar o magnetismo atômico, o apresentador diz que "pela lei fundamental que acabamos de ver [Lei de Ampère], os elétrons se movendo ao redor do núcleo [do átomo] têm que gerar um campo magnético. Isso equivale a dizer que todo átomo deve interagir com campos magnéticos; ou seja, todo átomo é um 'mini-ímã' com um polo norte e um polo sul". A frase é acompanhada de uma animação de um átomo feito inspirado no modelo de Bohr, onde dois elétrons orbitam circularmente um núcleo contendo dois nêutrons ${ }^{149} \mathrm{e}$ dois prótons.

Os erros deveriam ser claros para quem conhece a Física básica (incluindo noções de Mecânica Quântica). Em primeiro lugar, elétrons não se movem ao redor do núcleo da forma como é mostrada: sabemos, desde pelo menos Heisenberg, que as órbitas definidas são incompatíveis com o Princípio da Incerteza. O campo magnético atômico não tem origem em movimentos de nenhuma espécie, mas são propriedades intrínsecas de suas partículas constituintes, tendo, em realidade, origem no spin, não só dos elétrons como também dos núcleons. Dizer algo diferente disso é simplesmente errar. A interpretação clássica da origem do campo magnético como sendo o movimento de cargas elétricas não pode ser utilizada para explicar campos magnéticos intrinsecamente atômicos. Mas ainda há um segundo erro. Vamos supor que, apenas para "não complicar", queiramos explicar o magnetismo atômico utilizando somente conceitos clássicos (o que estaria errado de toda forma, mas talvez alguém [espero que não] considere justificável do ponto de vista pedagógico). Nesse caso, o erro está na animação que é mostrada no vídeo. Sabemos que uma espira

\footnotetext{
149 No modelo de Bohr, proposto em 1913, os nêutrons não eram considerados, pois ainda não haviam sido descobertos (isso ocorreu apenas em 1932). Não vou considerar isso como um erro do vídeo, uma vez que ele não cita o modelo de Bohr explicitamente, mas esse é um erro comum em materiais didáticos de química: ao apresentarem o modelo de Bohr já contendo nêutrons no núcleo, além de distorcer o modelo em si mesmo, cometem um erro historiográfico facilmente evitável.
} 
circular gera um campo magnético que é perpendicular ao plano da espira, de acordo com a Lei de Ampère e as regras de produto vetorial. A animação, porém, mostra um campo magnético que ocorre no mesmo plano que a suposta órbita circular dos elétrons. Esse não é um mero detalhe, mas é fundamental para o entendimento conceitual envolvido; com efeito, constitui uma das mais comuns dificuldades do ensino do eletromagnetismo clássico, especialmente no contexto do ensino médio, mas também, em alguma medida, do ensino superior.

Divulgar Ciência não é simples. Exige muito preparo, muito cuidado, boa didática e, acima de tudo, muito senso de responsabilidade. É preciso ter sempre em mente que o público leigo em geral não tem condições de reconhecer erros - sua atitude, ao contrário, é a de aceitar como certo tudo o que vê e ouve. Se ensinamos errado, o falso é aceito passivamente como sendo verdadeiro, e estamos fazendo um desserviço à educação científica em particular e à toda educação em geral.

\subsection{3 - Canal do Schwarza}

Esse canal, que conta com mais de 950 mil inscrições, superou, em 2019, o quarto colocado e tornou-se o terceiro maior canal de divulgação científica do Brasil. Apenas no ano citado, recebeu mais de 120 mil novas inscrições. O apresentador, conhecido como Schwarza, trabalha ativamente com a divulgação científica em diversas mídias, especialmente na área de astronomia. Em 2018, lançou o livro de divulgação "Do Átomo ao Buraco Negro - para descomplicar a astronomia", o qual tomei conhecimento através de uma aluna que o estava lendo. O seu canal no YouTube possui majoritariamente vídeos relacionados a temas científicos, mas eventualmente são abordados outros assuntos e artigos de opinião. Por já ter analisado vídeos conceituais do canal Ciência Todo Dia, busquei por dois vídeos do Canal do Schwarza com uma abordagem diferente. Segue comentários acerca dos dois vídeos selecionados.

"Coach Quântico" - Essa Parada de Coach Foi Longe Demais! - dur.: 13min24s - publicado em 26 de abr. de 2019 e atualmente (jan/2020) acumula mais de 85 mil visualizações.

O vídeo trata do fenômeno de pseudociência chamado de "coaching quântico", que pretende fazer uso de conceitos da Física Quântica para auxiliar física e 
psicologicamente seus praticantes. Em 1m24s, o apresentador lê uma definição do termo "coach":

"O coaching é um processo que visa elevar a performance de um indivíduo, grupo ou empresa aumentando os resultados positivos por meio de metodologias, ferramentas e técnicas cientificamente validadas [neste momento, o apresentador dá ênfase e repete a afirmação "cientificamente validadas"], aplicadas por um profissional habilitado que é o coach e em parceria com o cliente, que é o coaching."

Logo a seguir, ao ler novamente a afirmação de que o coaching é "cientificamente validado", o apresentador diz, em 2m08s, para o público perceber que o "'cientificamente' é uma coisa muito valorizada no discurso do coaching". Surge então uma boa oportunidade para tratar com o público o importante tema das pseudociências. O apresentador deixa claro que não quer generalizar seus comentários, pois sabe que existem coachs que realizam seriamente os seus trabalhos, mas direciona suas críticas especialmente ao caso do "coaching quântico". Por volta de $4 \mathrm{m05s}$, ele relata ter visto casos sobre "como emagrecer usando física quântica" ou como "vencer a depressão", também com física quântica. A abordagem é bem equilibrada, com objetivos didáticos e sem comentários demasiadamente ásperos. Ele explica ao público que a Teoria Quântica é diferente das teorias da chamada Física Clássica.

Em 4m52s, há um equívoco quando diz que as partículas subatômicas "não obedecem a gravidade". Provavelmente, ele quis dizer que não existe ainda uma teoria de gravitação quântica estabelecida, mas dizer que, literalmente, as partículas subatômicas "não obedecem a gravidade" é um equívoco: os corpos macroscópicos estão sujeitos à gravidade, mas os corpos macroscópicos são formados por aquelas mesmas partículas citadas, de maneira que seria impossível o corpo estar sujeito à gravidade sem que suas partículas também estivessem. Afinal, quando um corpo cai sob efeito gravitacional, o que está ocorrendo a nível atômico é a queda conjunta de todos as partículas que formam o próprio corpo! O que é o corpo senão a soma de suas partículas mais as interações existentes entre elas?

Em 5m23s, o apresentador ressalta que a Teoria Quântica é um estudo relativamente recente, e que, portanto, possui muitas lacunas. Ele diz que é preciso [os itálicos são meus] "mais observações e mais testes, [ou seja], toda a metodologia científica de praxe para tentar chegar a algumas conclusões [...] dentro desse ramo 
da Física teórica".

É verdade que mais observações e mais testes sempre serão necessários e é imprescindível que a Ciência obtenha tanta informação empírica quanto possível. Mas é notável a forma como o apresentador aborda o tema, enfatizando a observação e o teste, mas ao final chamando o ramo de Física teórica. Não era o tema em foco no vídeo, mas essa foi uma boa oportunidade para se ter abordado a Natureza da Ciência. Uma opção seria ressaltar que as observações visam suprir as ditas "lacunas", mas também é preciso entender que certas "lacunas" apenas poderão ser resolvidas por via teórica, uma vez que toda teoria é incompleta e "aguarda" o momento de ser revisada, corrigida ou substituída. Também poderia ser dito algo acerca da importante questão do "empirismo versus racionalismo", que já abordei em outra seção.

Aos 6 minutos, é dito que algumas pessoas utilizam-se dessas lacunas como oportunidades para atrair público. Ele descreve pseudociência como...

"Algo que se apresenta como se fosse científico, usa termos científicos, fala de uma maneira técnica, mas para um entendedor do que a pessoa está falando, para um físico, quando ele escuta essa pessoa falando um monte de 'baboseira' que se disfarça de algo técnico, ele percebe que é 'lorota': ou a pessoa não sabe o que está falando ou é desonesto."

Agora caberia, talvez, um comentário ao público: quem usa artifícios pseudocientíficos poderiam talvez serem levados mais a sério se publicassem artigos, desenvolvessem pesquisa seriamente, com metodologias claras e com possibilidade de revisão por pares etc. O apresentador chega a comentar algo sobre a ausência desse tipo de trabalho por parte deles. Sobre o "coaching quântico", ele lê, em 7m13s, uma definição:

"É uma vertente [de coaching] ainda pouco abordada, mas que tem como seu objetivo maior o alinhamento energético, influenciado pela Física Quântica desenvolvida pelo físico Albert Einstein [o apresentador abre um parêntesis e diz que 'Albert Einstein não foi o criador da Física Quântica' - a pessoa não sabe o que está falando]. Esse método prega que tudo é energia e que a forma como gerenciamos essa força diz muito sobre o nosso comportamento [o apresentador faz aqui uma 'piada' irrelevante]. Emoções, crenças e resultados também trazem influências para os métodos da 'cura quântica', desenvolvido pelo médico indiano Deepak Chopra." 
É claro que a pessoa que deu essa "definição" procurou utilizar-se do nome de Albert Einstein para ganhar alguma credibilidade, especialmente por ser um nome mais conhecido do público do que "Planck" ou "Heisenberg", mas também não é exato afirmar que "Albert Einstein não foi o criador da Física Quântica". Ele não foi o único, é óbvio, mas a sua adoção do quantum de Planck para interpretar a luz e explicar o efeito fotoelétrico foi, e ainda é, parte importante da Física Quântica. Ainda que Einstein divergisse da direção que a Física Quântica tomou nas décadas seguintes, ele próprio havia dado uma contribuição fundamental para os inícios do desenvolvimento da Teoria.

O apresentador diz, em 8m04s que, apesar de cético, ele deu o "benefício da dúvida" e foi pesquisar por publicações científicas produzidas por esses grupos de pseudociência, as quais não encontrou. Ele ainda recomenda ao público que também façam isso, para evitar acreditar em algo sem embasamento. Enfim, de forma geral e como já dito, o vídeo trata o tema de forma equilibrada e parece cumprir com o seu propósito informativo.

Adeus Big Bang? - Nova teoria Para a Origem do Universo - dur.: 5min55s publicado em 9 de jun. de 2017 e atualmente (jan/2020) acumula mais de 650 mil visualizações.

O vídeo aborda o tema das perguntas fundamentais: de onde viemos? Qual a origem de tudo? Em 1m10s, ele diz que "filósofos, religiosos e cientistas 'debruçaram' noites a fio tentando encontrar pistas para o nascimento do Universo. No caso da Ciência, conseguimos, ao longo dos anos, captar pequenos rastros do que pode ter ocorrido". Confesso que muito me surpreendi com a forma em que as questões foram colocadas. Talvez esse seja um dos melhores exemplos da tão proclamada "humildade científica": ele não fala de explicações conclusivas, mas de "captar pequenos rastros", não do que ocorreu, mas do que "pode ter ocorrido". É importante notar que isso não é maldizer ou menosprezar a Ciência: esses "pequenos rastros" que servem de pista para o que "pode" ter ocorrido continua tendo o seu valor preciosíssimo; continua sendo praticamente tudo o que temos de acessível acerca da origem do Universo. Ao mesmo tempo, admite que é muito pouco quando comparado a tudo o que ainda não sabemos, deixando a questão em aberto para futuras novas (e melhores) explicações. Novamente, de nada adianta dizer que a Ciência é "humilde e reconhece que não tem respostas para tudo", e ao mesmo tempo fazer, 
categoricamente, afirmações firmes e seguras acerca de assuntos tão distantes como a origem do Universo, não dizendo que são "pistas", mas que são "comprovações" de nossas teorias. O efeito observado costuma ser o oposto do supostamente pretendido: o surgimento de uma arrogância cientificista.

O apresentador segue contando um breve histórico das observações e dos cientistas que deram origem à Teoria do Big Bang. Em 2m09s, ele diz:

"Como a Ciência não é feita de convicções, a Teoria sempre esteve aberta a reavaliações e, recentemente, foi proposto que o Universo poderia ter nascido depois que uma estrela de quatro dimensões se colapsou em um buraco negro e expulsou detritos. Absurdo? Talvez, mas uma das limitações da teoria do Big Bang é nos dizer o que havia antes da grande expansão. A verdade é que o Big Bang deixa muitas questões. Por exemplo, como ele teria produzido o Universo com uma temperatura tão uniforme em tão pouco tempo? Apesar dele ter 13,8 bilhões de anos [de acordo com a Teoria], o Universo teria que ter se expandido mais rápido do que a luz para que a temperatura que encontramos nele fosse possível. E, mesmo assim, ainda restariam muitas questões a serem respondidas."

Compare o leitor essa forma de abordagem com aquela exposta no vídeo que analisei do Canal Nerdologia. Embora o vídeo daquele canal cite as perguntas não respondidas, é também afirmado que realmente o Universo tem 13,8 bilhões de anos (ao invés de dizer que esse é o fruto de um cálculo de um modelo teórico atual, sujeito a revisão) e, o que é mais grave, que as pesquisas científicas nos levariam inevitavelmente a esse valor para a idade do Universo.

O apresentador segue explicando a nova teoria da explosão da "estrela de quatro dimensões", dizendo que esse modelo explica a questão da temperatura uniforme presente em nosso Universo. Em 3m58s, temos a sua fala final:

"Como eu disse, esse é um modelo. Um modelo que diz que o Universo surgiu de um buraco negro. Como esse ainda não foi publicado, ele ainda não tem o aval da comunidade científica. O modelo convencional do Big Bang ainda é o mais aceito. Talvez, a complexidade do início nunca seja decifrada por completo pela nossa raça. Continuamos captando os cacos do que o Universo foi um dia para saber exatamente o que é esse 'foi'; colamos seus fragmentos na tentativa de descobrir como era seu formato original. Vez ou outra, podemos colar pedaços de maneira errada, e acreditar por um tempo, que aquilo é o correto, até surgir uma peça que se encaixa melhor. E colocar a última peça desse quebra-cabeça não é garantia que iremos entender a 
imagem que se formou. Mas isso não tira a emoção que foi encaixar cada peça em seu lugar."

Novamente, tomo esse como um exemplo de como a divulgação científica pode ser feita. Estamos falando de um dos temas mais profundos e complexos, que é a origem de tudo. Ainda assim, é possível abordar o assunto de forma agradável e interessante, sem tantas minúcias técnicas (mas também sem erros conceituais), e sem ter que fazer um apelo ao humor ou a piadas irrelevantes. Para completar, o assunto é abordado com cautela, com parcimônia, sem afirmações que pareçam indicar um grande grau de certeza (que, certamente, não existe - a não ser no entendimento dos defensores do cientificismo), e, portanto, sem distorcer a Natureza da Ciência. Ao mesmo tempo, valoriza o conhecimento em si mesmo, mostrando que a própria jornada, a busca pelo saber, ainda que não nos dê grandes garantias, é valiosa e gratificante por si só. Por fim, há aqui algo muito interessante de ser notado, e pode inclusive ser um ponto de partida para pesquisas futuras: sob vários dos critérios adotados, a divulgação científica realizada por esse canal foi de qualidade superior a dos demais; justamente o canal de um apresentador que não possui formação científica oficial/acadêmica, mas é alguém que pura e simplesmente ama a Ciência. Talvez a divulgação científica possa estar realmente em melhores mãos se os divulgadores não tiverem passado pela nossa deformante formação científica universitária...

\subsection{4 - Canal do Pirulla}

Apesar de ser apenas o quarto maior canal de divulgação científica brasileiro, tendo acompanhado a sua história posso concluir sem grande margem de erro que ele foi o mais influente. Para começar, é o mais antigo dentre os quatro analisados, tendo sido criado ainda em 2006. Os vídeos lançados pelo apresentador, Pirula (pseudônimo de Paulo Miranda Nascimento), começaram a ser lançados em série a partir de 2009, época em que havia bem poucos canais no YouTube e um muito menor número de usuários. Naquela época, outros canais de divulgação científica tinham algum espaço, mas com o decorrer do tempo, o Canal do Pirulla foi o único a sobreviver. Ele acabou sendo um grande influenciador para outros canais similares, como os três outros presentes nesta seção. Atualmente, o canal conta com mais de 
850 mil inscrições.

O apresentador trata principalmente de Ciência em seus vídeos, mas trás também temas outros, como política e religião (ele pode, ou ao menos podia, ser considerado um ativista do ateísmo). Em 2019, lançou o livro Darwin Sem Frescura, o qual teci comentários na seção anterior. Com relação aos seus vídeos, devido ao grande número disponível, escolhi um que trata especificamente do tema da presente dissertação.

Falseabilidade (ou por que não conto como virei ateu) - dur.: 13min17s publicado em 9 de ago. de 2012 e atualmente (jan/2020) acumula mais de 175 mil visualizações.

Dentre todos os vídeos em português com contém "falseabilidade" ou "Karl Popper" no título, esse é o de maior número de visualizações. A miniatura do vídeo trás, inclusive, uma foto do filósofo e de cisnes brancos, aludindo ao seu clássico exemplo para ilustrar o Critério de Falseabilidade. Para fins de comparação, o vídeo com mais visualizações que contém "Thomas Kuhn" em seu título possui 67 mil visualizações (foi lançado em 2016, mas a sua taxa de crescimento parece ter estagnado). Digo isso para ilustrar um fato curioso da divulgação científica brasileira na internet: Karl Popper e seu Critério, que ocuparam boa parte do presente trabalho, parecem ser os únicos (ou uns dos únicos) filósofos da Ciência (ou conceitos de Filosofia da Ciência) conhecidos. Curiosamente, o termo "Mudança de Paradigma" aparece em muitos outros vídeos com centenas de milhares de visualizações, mas sem terem relação com Ciência!

No vídeo, o autor pretende explicar o motivo de não contar por que virou ateu, e isso tem relação, segundo ele, com o Critério de Falseabilidade, o qual decide explicar primeiro. No tempo de 50s, ele diz que a Falseabilidade é "mais ou menos como a Ciência funciona hoje: apesar de não ser uma regra pétrea, ela [a Falseabilidade] funciona de uma maneira muito interessante e é ótima para o mecanismo científico". Em seguida, ele explica brevemente o Problema da Indução (sem citar a palavra "indução" neste momento), que, segundo ele, era o motivo da Ciência dos séculos anteriores apresentar problemas (pergunto: a atual não apresenta?). Em 1m28 ele diz que "você olhar quarenta e sete mil vezes um fato não prova que ele é universal" - o que é verdade: é o Problema da Indução. Por volta de $1 \mathrm{~m} 50$, ele cita a solução de Popper para o problema do método indutivo (agora sim, 
citando o termo "indutivo"), sugerindo o método hipotético-dedutivo. Ele segue explicando brevemente como o Critério funciona, e, em $2 \mathrm{~m} 54$, diz que "para termos uma frase científica", devemos ter "um ponto de falseabilidade".

Aqui encontramos o primeiro problema: existem inúmeras proposições na Ciência (ou "frases científicas", em suas palavras) que não são falseáveis. Já comentei muitas delas ao longo desta dissertação.

A seguir, ele explica o que é a falseabilidade. Em 3m42, o apresentador diz que "[devemos ir atrás] do ponto de falseabilidade, porque é ele que vai reforçar a minha teoria; a minha hipótese no caso - ela vai virar uma teoria se ela for mostrada verdadeira: a teoria é o máximo grau de comprovação de uma ideia científica". Essa frase resume grande partes dos conceitos equivocados que busquei elucidar nesta dissertação. Para começar, a ideia de que hipóteses viram teorias "se ela for mostrada verdadeira". Expliquei em detalhes esse ponto anteriormente: hipótese e teorias são essencialmente a mesma coisa, e isso não possui relação nenhuma com seu grau de "veracidade" - uma proposição (ou conjunto de proposições) é verdadeira ou falsa independentemente se é chamada de hipótese/teoria ou não. Uma teoria não deixa de ser uma teoria se for "provada falsa", assim como uma ideia considerada verdadeira (como o Teorema de Pitágoras) não se torna uma teoria por ser verdadeira (nesse exemplo, é justamente um teorema e não uma teoria!). Podemos, para fins didáticos ou elucidativos, classificar uma hipótese como sendo uma proposição ou pequeno grupo de proposições, enquanto uma teoria seria um grande grupo ou sistema de proposições, mas o caráter permanecerá o mesmo: ambas possuem caráter hipotético, e, portanto, não há divisão real, nem transformação de uma em outra. Esse erro é comum e já o vi replicado em outros lugares.

O segundo problema da frase de Pirula é quando diz que a hipótese pode ser provada verdadeira (caso falhe o teste que possivelmente iria falseá-la). Ora, se "quarenta e sete mil fato observados" não confirmam a universalidade do fato (por via indutiva), um experimento que falha em falsear o fato também não (por via hipotéticodedutiva). O Critério de Falseabilidade em momento algum foi proposto como meio de provar a veracidade de hipóteses (ver Popper, 2013, pp. 300-2).

Além disso, dizer que uma "teoria é o máximo grau de comprovação de uma ideia científica" é completamente absurdo. Teoria não é nome ou título de um "grau de comprovação"; uma teoria possui um determinado grau de corroboração, que pode 
variar de zero até muito alto, sem que isso altere em absolutamente nada o seu título de "teoria". A Teoria do Flogisto ou da Força Viva, ou o Geocentrismo, ou dos Quatro Elementos, são, sempre foram e sempre serão teorias científicas, não importando se são consideradas falseadas, não corroboradas, ou o que quer que seja. Normalmente, reluta-se chamar essas ideias antigas de "teorias científicas" pois, para a visão cientificista equivocada defendida na atualidade, uma "teoria científica" é algo "verdadeiro" ou algo que possui "alto grau de comprovação". É uma confusão de categoria: "teoria" é uma "substância conceitual", no sentido de ser um ente autônomo, enquanto que "grau de comprovação (corroboração seria o termo mais adequado)" é um acidente (especificamente, uma quantidade) associada àquele ente denominado teoria. Pertencendo a categorias diferentes, jamais poderiam "ser a mesma coisa" (como um martelo não pode ser uma cor, ou uma árvore não pode ser um sistema político).

Em 8m13s, o apresentador diz que "tem uma mente muito científica", que "pensa de uma forma científica", e que "tenta falsear" as suas "hipóteses pessoais". Aqui vemos que, para ele, o pensamento científico é equivalente, ou se confunde, com o Critério de Falseabilidade. Já havia comentado isso em outra seção: há quem utilize o Critério de Popper como "definição de Ciência" ou do que é "Científico", reduzindo todo o complexo mundo científico, que inclui um número gigantesco de fatores das mais diversas naturezas, a uma simples regra metodológica-epistemológica que, como já foi demonstrado, apresenta sérios problemas para a própria prática científica. Esse tipo de visão, assim como as falsas concepções da natureza das teorias, é bastante comum, como já dito e claramente demonstrado nesse exemplo, nos meios de divulgação brasileiros. O resultado é apenas um: distorções cientificistas disseminadas com o rótulo de "Ciência".

Ao tempo de $8 \mathrm{~m} 50 \mathrm{~s}$, finalmente o apresentador explica o porquê de não contar como virou ateu. Irei resumir seu argumento: (1) se ele contar como virou ateu, a informação se tornará pública; (2) se ele encontrar alguém que se diz "vidente", essa pessoa poderá dizer a ele que "sabe como ele virou ateu" por meio de seus "poderes sobrenaturais"; (3) como ele não tem como saber se o vidente realmente obteve a resposta através de poderes sobrenaturais ou porque assistiu ao vídeo, é melhor então não contar como virou ateu, pois isso preserva o seu "ponto de falseabilidade": se o vidente demonstrar realmente saber sobre esse relato não contado publicamente, 
então essa seria uma evidência de que seus poderes sobrenaturais (aos quais o apresentador é cético) são reais. Entendo o que o apresentador quis dizer, mas o argumento parece não ter sentido: bastaria solicitar que o vidente relatasse qualquer outro evento da vida pessoal de Pirula (qualquer outra informação não pública, que só ele mesmo poderia saber - é quase certo que o "modo como virou ateu" não é a sua única informação nunca compartilhada). Acertando o vidente o seu relato, estaria Pirula falseado (que é o que ele pretende manter como possibilidade, de acordo com sua "maneira científica de pensar" [?]).

Enfim, sem entrar no mérito de suas convicções pessoais, o fato é que o vídeo contém visões distorcidas acerca da Natureza da Ciência: o Critério de Popper é superestimado, a relação existente entre hipótese e teoria é completamente falsa, assim como a relação entre teoria e grau de corroboração. Como dito, esse é um dos canais científicos mais influentes - se considerarmos sua influência indireta através dos outros três canais já comentados, então o Canal do Pirulla é, ou ao menos foi durante um longo tempo, de fato o canal científico mais influente de todos os canais brasileiros. Tem muito peso um vídeo desse tipo, com mais de 185 mil visualizações, e apresentado por alguém que transmite bastante credibilidade no que fala. 


\section{CONSIDERAÇÕES FINAIS}

Ao longo do presente trabalho, busquei esclarecer tão abrangentemente quanto possível os elementos constituintes da Natureza da Ciência. O grande objetivo era encontrar meios que pudessem ser úteis para uma melhoria da forma como a Ciência é entendida, ensinada e divulgada, assim como entender a maneira de atuação das distorções pseudocientíficas, anticientíficas e cientificistas que abundam por toda parte.

No primeiro capítulo, fiz uma singela revisão histórica acerca do problema da demarcação e definição do que a Ciência é. Apresentei a solução de Popper, suas consequências e as críticas que recebeu, especialmente de Kuhn. Explorei muitos dos conceitos fundamentais para se compreender Ciência, tais como a questão do empirismo, da relação existente entre teorias, leis e hipóteses, assim como a relação entre a Ciência, a fé e, sobretudo, a Filosofia. O capítulo foi finalizado com o tratamento do assunto que foi o principal alvo de toda a dissertação: as distorções pseudocientíficas, anticientíficas e cientificistas. Nos parágrafos seguintes, direi algumas considerações finais acerca delas.

No segundo capítulo, foi abordado o problema do progresso científico. O tema poderia ter sido incorporado como um tópico extra no primeiro capítulo, mas a sua importância e a profundidade com quis abordá-lo me levaram a dedicar-lhe um capítulo exclusivo. Após contrapor as ideias de Kuhn com a maneira que tal tema é normalmente exposto, termino com um curto ensaio relacionando o progresso científico com o tecnológico.

Após a revisão teórica dos dois primeiros capítulos - um recorte, evidentemente, de tudo o que poderia ter sido abordado — somei, no terceiro capítulo, análises de materiais de divulgação modernos e de amplo alcance. Lembro aqui o que já havia adiantado na introdução do trabalho: os capítulos primeiro e segundo tinham o principal propósito de servir ao terceiro - ele é o coração do trabalho. Nele, o leitor pôde ver, por si mesmo, que os erros comuns que vim anunciando nos primeiros capítulos eram reais e estão de fato presentes nas falas dos principais divulgadores das últimas décadas. A lista de ideias distorcidas encontrada nessas análises é imensa: de cientistas pregando a "morte" da filosofia a cientistas dizendo que ideias hoje abandonadas eram "suposições tiradas do nada", enquanto as ideias atuais "são 
baseadas em evidências"; divulgadores fazendo "mágica" com a história e com a epistemologia ao afirmar que "fulanos fizeram tal experimento para 'provar' que tal coisa não existe"; divulgadores dizendo que a Ciência é a "mãe" do ceticismo, além de ser "o nosso primeiro conhecimento universal" e, pasmemos, o nosso admirável bastião de humildade! (Desde que não nos esqueçamos — nem questionemos - que o Universo surgiu de uma colossal expansão há 13,8 bilhões de anos, que a vida surgiu espontaneamente numa sopa primordial, ou ainda que o núcleo do planeta Urano é feito de silicatos e rochas de Ferro-Níquel!) Também vimos divulgadores afirmando que nossas teorias refletem "a realidade", de tal forma que qualquer um chegaria às mesmas conclusões ao investigar os mesmos fenômenos; divulgadores que afirmaram que "pensar cientificamente" é "pensar em termos de falseabilidade" (ainda que a Ciência só exista em dependência de afirmações completamente nãofalseáveis! - mas isso parece não ser do conhecimento de quem fez a afirmação); divulgadores defendendo a falseabilidade de Popper, mas ignorando sumariamente a atitude agudamente crítica do filósofo, adotando, ao invés disso, a postura da defesa ferrenha de teorias, com direito a blindagens ad hoc vendidas como "fatos da Natureza". Tivemos até mesmo divulgadores defendendo ser a Ciência a "guardiã dos valores da nossa civilização", e que "se os cientistas não assumirem essa responsabilidade de guardiões, quem o fará?"! Notemos que a lista de superpoderes da Ciência parece não encontrar qualquer limite para seu potencialmente imparável crescimento. A lista segue, e certamente poderia ser muito maior, se levarmos em conta que a minha análise foi apenas e tão somente um pequeno recorte. Tal resultado se acumula ao de tantos outros pesquisadores, alguns citados nesta dissertação, que também puderam verificar tais problemas em outros materiais de divulgação, inclusive em outras mídias, como revistas e programas televisivos.

O trabalho foi extenuante, mas, ainda assim, não foi exaustivo: cada um dos tópicos teóricos abordados pode ser muito mais aprofundado, e a pesquisa de fronteira em História e Filosofia da Ciência, tanto no contexto "duro" quanto no contexto educacional, prossegue a todo vapor.

Estou plenamente consciente de que adotei posições bastante controversas nesse trabalho. Propus que a Ciência é filha e inteiramente dependente da Metafísica e da Teoria do Conhecimento, não tendo valor próprio caso fosse separada dessas últimas; propus que leis, hipóteses e teorias são essencialmente a mesma coisa; 
propus que a fé, sobretudo a fé metafísica, é imprescindível para o empreendimento científico; defendi realmente, e não só de aparência, que nenhum conhecimento científico é final, o que levou-me a questionar os fundamentos de tão queridas teorias quanto a Relatividade e a Evolução; defendi um retorno aos objetivos mais puristas da Ciência, como a busca sincera pelo conhecimento do mundo natural, tornando a Ciência um fim em si mesma, e não apenas um degrau para o domínio tirânico, via tecnologia ou argumentos de autoridade científica, da natureza, dos corpos e das almas. Isso, é evidente, não significa que eu acredite que a Ciência é, ou pode realmente ser, perfeitamente neutra; isso tão somente significa que, frente aos abusos dos quais a Ciência vem sofrendo, é urgente a necessidade de pessoas realizando salvaguardas dessa espécie, afim de preservá-la de ser um instrumento de tirania nas mãos dos poderosos - incluindo aqui não apenas governantes ou grandes empresários, mas também as ditas autoridades científicas ${ }^{150}$.

Todos esses pontos, alguns mais do que outros, podem causar incômodo ou mesmo ferir susceptibilidades. Sei disso. Como também já dito mais de uma vez, não espero críticas menos duras às minhas próprias ideias do que aquelas que fiz às ideias dos outros; nesse ponto, alinho-me a Popper e estou realmente disposto a rever incessantemente cada um dos meus argumentos, destruindo-os se necessário, apenas para novamente reconstruí-los de forma ainda mais precisa, rigorosa e sólida. Não tenho "ideias de estimação", e repudio o desejo de querer estar "certo" a todo custo, mas busco tão somente encontrar a maneira mais clara e lúcida de pensar e de compreender a realidade e o Cosmo onde vivemos, nos movemos e somos.

O ano de 2020, especialmente devido à "corona crise", foi muito frutífero para

150 Hoje, dia 14/01/2021, preciso dizer o quão decepcionante foi tomar conhecimento da nova
publicação na coluna do divulgador Atila lamarino (um dos divulgadores analisados nessa
dissertação), no jornal Folha de São Paulo. O título da coluna é: "Autoritarismo necessário-
Ou será preciso calar as vozes antivacina ou tornar a vacina compulsória". O divulgador
defende aqui, abertamente, que as "autoridades detentoras do conhecimento" têm o direito
de praticarem uma espécie de "autoritarismo do bem", silenciando à força o debate público
acerca das vacinas. Não consigo imaginar nada mais elitista, cientificista e tecnocrata do que
isso. O choque é ainda maior quando tal discurso autoritário vem de alguém que se proclama
"antifascista". Lembrando que a "corona crise" teve como primeiros capítulos justamente o
autoritarismo e censura do Partido Comunista Chinês para com seus próprios médicos e
jornalistas, os quais foram calados à força (alguns foram presos e outros, de fato, estão
desaparecidos), escondendo do mundo o cataclismo que daí se seguiria. Por fim, lembremo-
nos que todos os "autoritarismos" da história, do passado e do presente, foram praticados
supostamente em nome do "bem" do povo, e sempre com uma casta de "iluminados" para
justificar intelectualmente o abuso do poder e o uso da força bruta. Link para a coluna:
https://www1.folha.uol.com.br./colunas/atila-iamarino/2021/01/autoritarismo-necessario.shtml 
fins dos tópicos aqui abordados: nós, que buscamos compreender e contribuir para com a Ciência, tivemos inúmeras oportunidades de confrontar diretamente nossas próprias convicções com as realidades impostas pela condição adversa surgida em Wuhan. Pude testemunhar tantos casos de pessoas esclarecidas, dedicadas a analisar criticamente o fazer científico, esquecendo-se dos pontos mais elementares que a pesquisa acadêmica tem enfatizado, tal como a ausência da já citada autêntica neutralidade científica - ou seja, a inexistência de uma Ciência "apartidária" e "livre de ideologias". Também vi, lamentavelmente, muitos se esquecendo do mais sagrado princípio da honestidade intelectual: o princípio de que ideias e argumentações precisam sustentar-se por si mesmos, e não por meio do prestígio ou autoridade de quem o profere. Com isso, mesmo alguns dos que efetivamente se colocavam contra o cientificismo se viram abraçando essa distorção. Talvez tenha sido disparado na psique de tais pessoas o mecanismo primitivo de defesa, que nos faz buscar por segurança a todo custo frente a uma ameaça externa iminente, passando por cima de nossas considerações mais frias e racionais, e levando-nos a abrirmos mão dessas mesmas considerações. Para esses, deixo a famosa frase de Benjamin Franklin: "Aqueles que abrem mão da liberdade essencial por um pouco de segurança temporária não merecem nem liberdade nem segurança".

Somemos a isso o ataque dos movimentos anticientíficos, e o que temos é uma guerra ideológica que "brinca" com nossos bens mais preciosos: nossa vida e nossa liberdade. O resultado final é que certamente houve, durante esse período, um agigantamento tanto de uma posição quanto da outra. Chegamos ao extremo de vermos autoridades defendendo tratamentos bizarros utilizando ozônio (felizmente, o nível de absurdidade foi tão elevado que o caso acabou tornando-se apenas uma piada inofensiva) e outros medicamentos exaustivamente atestados como ineficazes, enquanto, do outro lado, vimos princípios normalmente considerados invioláveis sendo sumamente obliterados "em nome da Ciência". "Isso não é questão de 'direita' ou de 'esquerda'! Isso é uma questão de Ciência! Vamos ouvir a Ciência! Vamos obedecer as autoridades científicas!", dizem eles. Nada poderia ser mais lamentável, e nada poderia deixar a nós, educadores e estudiosos da Ciência, mais alertas acerca do nosso papel nessa infeliz contenda.

Chamei de "distorções" as posições citadas. Sinto-me hoje inclinado a mudar o termo: são verdadeiras corrupções da Ciência. Amar a Ciência significa também 
querer protegê-la de ser corrompida, o que implica combater o inimigo interno do cientificismo, e os inimigos externos das pseudociências e dos movimentos anticiência. As armas para tal combate são o conhecimento e a virtude de bem transmiti-lo. Infelizmente, o problema é demasiadamente complexo, e todo esforço feito até o momento parece ainda muito pouco. Que o presente trabalho tenha servido para contribuir com mais munição aos que lutam nos mais diversos fronts dessa cruzada.

Lembremo-nos da frase de Lord Acton: "O poder tende a corromper, e o poder absoluto corrompe absolutamente, de modo que os grandes homens são quase sempre homens maus". Ora, e o que é o cientificismo senão dar grandes poderes à Ciência? Ora, e não é a Ciência feita de homens e mulheres? Não é o poder deles e delas que será aumentado com o fortalecimento do cientificismo em nosso universo cultural? O que será de nós quando cientistas, corrompidos pelo poder que lhes demos, ditarem, com interesses ocultos e obscuros, os rumos que nossa sociedade deverá seguir? O que será de nós quando os cientistas se aliarem a políticos para elaborarem ao seu bel prazer esses mesmos rumos? Estaríamos rumando para um distópico futuro tecnocrata? Em dezembro de 2019, quando a maior parte do presente trabalho foi redigida, esses temores pareciam distantes, frutos da imaginação frutífera de algum autor de ficção científica, e sem configurarem ameaças realmente tangíveis. Atualmente, em dezembro de 2020, eles subitamente parecem ter tomado forma, corpo, substância e realidade. Basta ver, por exemplo, livros como COVID-19: The Great Reset (2020, ver referências), escrito por autoridades acadêmicas mundiais, amplamente amparadas pela comunidade científica, descrevendo esse mesmo futuro tecnocrata distópico, não numa obra de ficção, mas numa obra com aval das grandes potências mundiais e sob a tutela da ONU e do Fórum Econômico Mundial.

Mas será que toda essa crítica ao cientificismo significa estar do lado dos movimentos anticientíficos? De forma alguma! Nunca! Jamais! Amamos a Ciência, e por isso mesmo, novamente, tão somente queremos protegê-la de ser corrompida. A Ciência não precisa de "poder": a Ciência precisa apenas de espaço para fazer aquilo que é a sua função primordial - a ampliação do conhecimento da humanidade com relação ao mundo natural. Esse é o propósito de Ser da Ciência. Ela é um fim em si mesma, e não um degrau para a satisfação de uma ambição desmedida da qual, tragicamente, estamos todos sujeitos a padecer precisamente devido à nossa 
natureza humana, demasiadamente humana. Usar a Ciência como mero instrumento de poder para oprimir, para tiranizar, para enganar, para censurar, para calar, para subverter a ética, a vida e a liberdade, é o maior sacrilégio que poderíamos estar cometendo para com ela. Tal subversão da Ciência começa com a subversão dos próprios conceitos que perfazem a sua Natureza.

Muitos autores trataram das "concepções ingênuas" da Ciência. Denominei-as de "distorções". Mas, como já dito, o problema parece ter evoluído, tal como um câncer de implacável agressividade, e, digo uma vez mais, as "distorções" já poderiam ser tratadas como autênticas e venenosas corrupções. No primeiro capítulo do clássico $O$ Mundo Assombrado Pelos Demônios, de Carl Sagan, há uma citação de um dos mais belos insights de Einstein acerca da Ciência: "Toda a nossa ciência, comparada com a realidade, é primitiva e infantil... e no entanto a coisa mais preciosa que temos". Infelizmente, o cientificismo tende a ignorar a primeira parte desse enunciado, enquanto os movimentos anticiência fecham os olhos para a última. $E$ nesse inútil e infeliz cabo de guerra, quem perde somos todos nós.

A Ciência possui as suas regras, seu território, seus objetivos. Outras áreas do saber, como a História ou a Religião, essa última vista normalmente como a motivação por trás da negação da Ciência, também têm suas regras, seus territórios, seus objetivos. Líderes fundamentalistas dos movimentos anticiência, tolos e desinformados, utilizam de motivações religiosas ou até mesmo supersticiosas para negar a Ciência. Cientistas e divulgadores, igualmente tolos, usam a Ciência para negar as bases da fé religiosa, a Filosofia, ou qualquer outra área do saber que não desfrute dos atributos da entronada Ciência. É verdade que todos, enquanto indivíduos, têm o direito de usar os conceitos que quiserem para justificar seus pontos de vista. Os problemas começam quando isso é feito em nome "da Ciência" ou "da Religião". Cada um é livre para escolher qual dos dois conjuntos de regras quer conhecer e seguir, ou mesmo escolher a ambos, desde que sejam aplicados cada um de forma consciente, coerente e construtiva, em seu próprio território, sem a intenção de anular os demais campos do saber. O conhecimento dessas regras é a vacina e o antídoto para o cientificismo, para os movimentos anticiência e para a pseudociência.

É preciso, do lado cientificista, abandonar ideias intransigentes, como a falsa dicotomia entre Metafísica/Filosofia e a Ciência (vista como a "forma superior do conhecimento", instaurada pelos positivistas e seus simpatizantes - visão essa que 
insiste como erva daninha no imaginário cientificista); a falsa noção de que as teorias científicas são retratos da realidade que a Ciência revela "comprovadamente pela experiência"; a falsa crença de que qualquer uma de nossas teorias, as atuais e as que virão no futuro, são definitivas; a falsa crença de que o conhecimento científico pode e deve ditar o destino da humanidade. Do lado da anticiência, contra as inúmeras evidências empíricas que suportam nossas atuais teorias, não faz sentido negá-las através de dogmas: que aceitem tais dogmas apenas como dogmas, abandonando de vez qualquer tentativa de fazer uso deles para interferir no jogo da Ciência, ou que optem por uma interpretação não-literal, em busca de uma conciliação de sua fé com o conhecimento empírico - conciliação essa plenamente possível de ser realizada, como atestam os muitos cientistas religiosos de notável lucidez do presente e do passado. As pseudociências são combatidas com estudo e informação. No mais, tendem a ser inofensivas, a não ser aos próprios adeptos, quando suas consequências são comparadas ao dos outros dois tipos de corrupção.

A Filosofia precisa ser revalorizada nos meios científicos. É ultrajante vermos cientistas, divulgadores e professores subestimando o conhecimento filosófico, supondo de forma vã que existiria Ciência fora e independente dos domínios da Filosofia. Sobretudo a Metafísica e a Teoria do Conhecimento, ao meu ver, as duas mais profundas e pertinentes áreas da Filosofia, sempre tiveram e continuarão tendo influência e participação decisiva na Ciência, mesmo que alguns cientistas continuem preferindo ignorar esse fato irrebatível.

Que o presente trabalho sirva como uma síntese aos professores e divulgadores de Ciência, para que possam rever suas abordagens em sala de aula e em materiais de divulgação. A internet tornou-se o meio mais veloz para aquisição de informação, tendo ultrapassado em muito o alcance e a eficiência dos sistemas educacionais tradicionais. Podemos utilizar esse potencial para ensinar o amor à Ciência, sem mascarar suas limitações, mas vendo-a, sim, como o nosso precioso tesouro do conhecimento humano acerca do mundo natural. Ou podemos tratar a Ciência como uma falsa religião, como um ídolo a ser idolatrado, com intransigência, ou com qualquer visão que tenda a nos afastar do espírito de sabedoria e de contemplação que uma vida culta e consciente necessita - o que apenas ajudaria a pavimentar o já bastante adiantado caminho para o distópico futuro tecnocrata que se anuncia no horizonte. Adoto, convicta e firmemente, a primeira posição. 


\section{REFERÊNCIAS}

AGASSI, J. Popper's demarcation of science refuted. Methodology and Science, 24, pp. 1-7. 1991.

ALDRICH, H. E. et al. In defence of generalized Darwinism. Journal of Evolutionary Economics, v. 18, n. 5, pp. 577-96, 2008.

ANDEREGG, W. R. L. et al. Expert credibility in climate change. PNAS, July 6, vol. 107 (27), pp. 12107-9. 2010. Disponível em: www.pnas.org/content/107/27/12107

ARISTÓTELES. A Metafísica. São Paulo: Edições Loyola, 2002.

BACHELARD, G. A Formação do Espírito Científico. Rio de Janeiro: Contraponto, 2007.

BAGDONAS, A. Controvérsias envolvendo a natureza da ciência em sequências didáticas sobre cosmologia. Tese (Doutorado em Ensino de Física) - Ensino de Ciências (Física, Química e Biologia), Universidade de São Paulo. São Paulo, 2015.

BAGDONAS, A., SILVA, C. C. Controvérsias sobre a natureza da ciência na educação científica. In: Aprendendo ciência e sobre sua natureza: abordagens históricas e filosóficas. $1^{\text {a }}$ ed. São Carlos: Tipografia, pp. 209-18, 2013.

BAGDONAS, A.; ZANETIC, J.; GURGEL, I. Controvérsias sobre a natureza da ciência como enfoque curricular para o ensino da física: o ensino de história da cosmologia por meio de um jogo didático. Revista Brasileira de História da Ciência, Rio de Janeiro, v. 7, n. 2, pp. 242-60, jul | dez, 2014.

BAGDONAS, A.; ZANETIC, J.; GURGEL, I. Quem descobriu a expansão do universo? Disputas de prioridade como forma de ensinar cosmologia com uso da história e filosofia da ciência. Rev. Bras. Ensino Física, vol. 39, no. 2. São Paulo, 2017.

$\mathrm{BISCH}$, S. Astronomia no $1^{\circ}$ grau: natureza e conteúdo do conhecimento de estudantes e professores. Tese (Doutorado em Educação) - Faculdade de Educação, Universidade de São Paulo. São Paulo, 1998.

BUNGE, M. Filosofia da Física. Lisboa: Edições 70, 1973.

BOYKOFF, M. T. Lost in translation? United States television news coverage of anthropogenic climate change, 1995-2004, Climatic Change, vol. 86, pp. 1-11, 2008.

CARDOSO, D. et al. Texto Jornalístico sobre Ciência: Uma Análise do Discurso sobre a Natureza da Ciência. ALEXANDRIA Revista de Educação em Ciência e Tecnologia, v.8, n.3, pp. 229-51, novembro 2015.

CARLSON, S. A Double Blind Test of Astrology. Nature, n. 318, pp. 419-25, 1985.

COMTE, A. Curso de Filosofia Positiva. São Paulo: Abril Cultural, 1978 (Coleção Os Pensadores).

SCHWAB, K; MALLERET, T. Covid-19: The Great Reset. $1^{\text {a }}$ ed. World Economic Forum, Cologny/Geneva: Forum Publishing, 2020.

DARWIN, C. A Origem das Espécies. Tradução da $6^{a}$ Ed. Leça da Palmeira: Planeta Vivo, 2009 (Coleção Planeta Darwin). 
DAWKINS, R. O Gene Egoísta. São Paulo: Cia. Das Letras, 2007.

DAWSON, C. A Criação do Ocidente. São Paulo: É Realizações, 2016.

DRIVER, R., ASOKO, H., LEACH, J., SCOTT, P., \& MORTIMER, E. (1994). Constructing Scientific Knowledge in the Classroom. Educational Researcher, 23 (7), pp. 5-12. 1994. Disponível em: https://doi.org/10.3102/0013189X023007005

DUHEM, P. The Aim and Structure of Physical Theory. Princeton: Princeton University Press, 1954.

DUNLAP, R. E.; JACQUES, P. J. Climate change denial books and conservative think tanks: exploring the connection, American Behavioral Scientist, 57(6): 699-731, 2013.

EL-HANI, C. N.; BIZZO, N. Formas de construtivismo: mudança conceitual e construtivismo contextual. Ensaio: Pesquisa em Educação em Ciências 4: 1-25, 2002.

FEYERABEND, P. K. Against Method. London: New Left Books, 1970.

FOUREZ, G. Crise no Ensino de Ciências. Investigações em Ensino de Ciências, v. 8, n. 2, pp. 109-23, 2003.

GLEISER, M. A Ilha do Conhecimento. 1ª Ed. Rio de Janeiro: Record, 2014.

GAMA, L. D. Autoridade da ciência e educação: abrindo caixas pretas com a problematização de discursos da mídia e temas da física. Dissertação (Mestrado) Instituto de Física, Instituto de Química, Instituto de Biociências, Faculdade de Educação - Programa Interunidades em Ensino de Ciências, Universidade de São Paulo. São Paulo, 2011.

GIL-PÉREZ, D. et al. Para uma imagem não deformada do trabalho científico.

Ciência \& Educação, v.7, n.2, pp.125-53, 2001.

HAACK, S. Six Signs of Scientism. Logos and Episteme, n. 3 (1), pp. 75-95. 2012. Disponível em https://doi.org/10.5840/logos-episteme20123151.

HANSSON, S. O. Defining Pseudoscience. Philosophia Naturalis, n. 33, pp. 169-76. 1996.

HANSSON, S. O. Falsificationism Falsified, Foudations of Science, n. 11, pp. 275-303. Stockholm: Tiden, 2006.

HANSSON, S. O. Philosophy in the Defence of Science, Theoria, n. 77, pp. 101-103. Stockholm: Tiden, 2011.

HAWKING, S.; MLODINOW, L. O Grande Projeto. Rio de Janeiro: Nova Fronteira, 2011.

HAWKING, S. Uma Breve História do Tempo, do Big Bang aos Buracos Negros. $3^{a}$ Ed. Lisboa: Gradiva, 1994.

HENRIQUE, A. B. Discutindo a natureza da ciência a partir de episódios da história da cosmologia. Dissertação de Mestrado em Ensino de Ciências, Universidade de São Paulo. São Paulo, 2011.

HOERNIG, A. F.; MASSONI, N. T.; LIMA, N. W. As visões sobre a ciência e sobre a realidade nos enunciados de Richard P. Feynman: Uma análise metalinguística de 
alguns de seus textos didáticos e de divulgação científica. Revista Brasileira de Ensino de Física, vol. 42, e20200019, 2020.

HUME, D. Investigação sobre o Entendimento Humano e sobre os Princípios da Moral. São Paulo: UNESP, 2004.

JOSEPH, M. O Trivium: As Artes Liberais da Lógica, da Gramática e da Retórica. São Paulo: É Realizações, 2008.

KEYNES, J. M. A Treatise on Probability. London: Macmillan, 1921.

KINOCHITA et al. Utilization of a Cyclic Dimer and Linear Oligomers of $\mathcal{E}$-Aminocaproic Acid by Achromobacter guttatus KI 72. Agricultural and Biological Chemistry, n. 39 (6), pp. 1219-23. Osaka, 1975.

KÖHNLEIN, J. F. K., PEDUZZI, L. O. Q. Uma discussão sobre a natureza da ciência no ensino médio: um exemplo com a teoria da relatividade restrita. Caderno Brasileiro de Ensino de Física, v. 22, n. 1, pp. 36-70, abril, 2002.

KRAUSE, D. Tópicos em ontologia analítica. $1^{\text {a }}$ Ed. São Paulo: Editora Unesp, 2017.

KRYSTAL, A. At Large and at Small: What do you Know?. American Scholar, 68(2), pp. 7-13, 1999.

KUHN, T. A Estrutura das Revoluções Científicas. $12^{\mathrm{a}}$ Ed. São Paulo: Perspectiva, 2013.

KUHN, T. A Tensão Essencial: Estudos relacionados sobre tradição e mudança científica. $1^{\text {a }}$ Ed. São Paulo: Editora Unesp, 2011.

KUTSCHERA, U. A comparative analysis of the Darwin-Wallace papers and the developmente of the concept os Natural Selection. Theory Bioscience, 122. 2003.

LANGUI, R.; NARDI, R. Ensino da astronomia no Brasil: educação formal, informal, não formal e divulgação científica. Revista Brasileira de Ensino de Física, v. 31, n. 4, 4402. 2009.

LAUDAN, L. et al. Mudança Científica: modelos filosóficos e pesquisa histórica. Ensaio. Estud. Av. vol. 7, no.19. São Paulo. Set./Dec. 1993.

LAUDAN, L. O Progresso e seus Problemas. $1^{\text {a }}$ Ed. São Paulo: Editora Unesp, 2010.

LEDERMAN, N. Nature of science: past, present and future. In: ABELL, S.K. e LEDERMAN, N.G. (eds), Handbook of Research on Science Education, pp. 831-80. Mahwah, New Jersey: Lawrence Erlbaum Associates, 2007.

LEDERMAN, N. G.; ABD-EL-KHALICK, F.; BELL, R. L.; SCHWARTZ, R. S. Views of nature of science questionnaire: towards valid and meaningful assessment of learners' conceptions of the nature of science. Journal of Research in Science Teaching, v. 39, pp. 497-521. 2002.

MAHNER, M. Demarcating Science from Non-Science. Pp. 515-75 in Theo Kuipers (ed.) Handbook of the Philosophy of Science: General Philosophy of Science - Focal Issues. Amsterdam: Elsevier, 2007.

MAHNER, M.; BUNGE. M. The incompatibility of science and religion sustained: a reply to our critics. Science \& Education, v. 5, pp. 189-99. 1996. 
MARTINS, R. de A. Em busca do nada: considerações sobre os argumentos a favor do vácuo ou do éter. Trans/Form/Ação, vol. 16, pp. 7-17. São Paulo, 1993.

MARTINS, R. de A. Como distorcer a física: considerações sobre um exemplo de divulgação científica - 1- Física clássica. Caderno Catarinense de Ensino de Física, vol. 15, no. 3, pp. 243-64. Florianópolis, 1998a.

MARTINS, R. de A. Como distorcer a física: considerações sobre um exemplo de divulgação científica - 2- Física moderna. Caderno Catarinense de Ensino de Física, vol. 15, no. 3, pp. 265-300. Florianópolis, 1998b.

MARTINS, R. de A. Que tipo de História da Ciência esperamos ter nas próximas décadas? Revista Episteme, no. 10, pp. 39-56. Porto Alegre, 2000.

MARTINS, R. de A. Como Não Escrever Sobre História da Física - um Manifesto Historiográfico. Revista Brasileira de Ensino de Física, vol. 23, no. 1, pp. 113-29. São Paulo, 2001.

MASSARANI, L.; LEAL, T.; WALTZ, I. O debate sobre vacinas em redes sociais: uma análise exploratória dos links com maior engajamento. Cad. Saúde Pública; 36 Sup 2:e00148319, 2020.

McCOMAS, W. F. The principal elements of the nature of science: Dispelling the myths of science. In: McCOMAS, W. F. (ed.) The Nature of Science in Science Education: Rationales and Strategies. Dordrecht: Kluwer Academic Publishers, pp. 5370. 1998.

McCOMAS, W.; ALMAZROA, H.; CLOUGH, M. P. The nature of science in science education: an introduction. Science \& Education, v. 7, pp. 511-32. 1998.

MILL, J. S. A System of Logic, Ratiocinative and Inductive: Being a Connected View of the Principles of Evidence and the Methods of Scientific Investigation, vol. 2. London: John W. Parker, 1843.

MORIN, E. O Método III: o Conhecimento do Conhecimento. $5^{\mathrm{a}}$ Ed. Porto Alegre: Sulina, 2015.

MOURA, D. O. Do campo científico ao jornalismo científico: o discurso sobre o valor da Floresta Amazônica. Tese (Doutorado em Ciências da Informação) — Universidade de Brasília. Brasília, 2001.

NAVAS, A. L. G. P. et al. Divulgação científica como forma de compartilhar conhecimento. CoDAS, São Paulo, v. 32, n. 2, e20190044, 2020. Disponível em: https://doi.org/10.1590/2317-1782/20192019044

NORONHA, A. Interpretando a Relatividade Especial: Discutindo o Debate Realismo e Antirrealismo Científicos no Ensino de Ciências. Dissertação de Mestrado, Universidade de São Paulo. São Paulo, 2014.

NUSSEnZVEIG, H. M. Curso de Física Básica: 4ª Ed. Vol. 1 e 4. São Paulo: Edgard Blucher, 2002.

OLIVEIRA, A. Física e ficção científica: desvelando mitos culturais em uma educação para a liberdade. Dissertação (Mestrado) - Instituto de Física, Instituto de Química, Instituto de Biociências, Faculdade de Educação - Programa Interunidades em Ensino de Ciências, Universidade de São Paulo. São Paulo, 2011. 
PIGLIUCCI, M. The Demarcation Problem: a (belated) response to Laudan in Philosophy of Pseudo Science. University of Chigaco Press, 2013.

PIRULA; LOPES, R. J. Darwin Sem Frescura. São Paulo: Harper Colins, 2019.

POOLE, M. W. For more and better religious education. Science \& Education, v. 5, pp. 165-74, 1996.

POPPER, K. A Lógica da Pesquisa Científica: $1^{\text {a }}$ Ed. São Paulo: Cultrix, 2013.

POPPER, K. Natural Selection and the Emergence of Mind. Cambridge, 1997.

PORTO, P. A.; SCHMIEDECKE, W. G. A história da ciência e a divulgação científica na TV: subsídios teóricos para uma abordagem crítica dessa aproximação no ensino de ciências. Revista Brasileira de Pesquisa em Educação em Ciências, vol. 15, no. 3. 2015.

PORTO, C. M. A Física de Aristóteles: uma construção ingênua? Revista Brasileira de Ensino de Física, vol. 31, no. 4. São Paulo, 2009.

PRAIA, J., CACHAPUZ, A., CARRASCOSA, J., GIL, D., FERNANDÉZ, I. Visiones deformadas de la ciência transmitidas por la enseñanza. Rev. Enseñanza de las ciencias, v. 20, n. 3, pp. 477-88, Universitat Autònoma de Barcelona. 2002.

PRAIA, J.; GIL-PÉREZ, D.; VILCHES, A. O papel da natureza da ciência na educação para a cidadania. Ciência \& Educação, v. 13, n. 2, pp. 141-56. 2007.

PRIJAMBADA et al. Emergence of Nylon Oligomer Degradation Enzymes in Pseudomonas aeruginosa PAO through Experimental Evolution. Applied and Environmental Microbiology. American Society for Microbiology, pp. 2020-2. Osaka, 1975.

PSILLOS, S. Scientific Realism: How Science Tracks Truth. London: Routledge, 1999.

PUTNAM, H. Mathematics, Matter and Method, Cambridge: Cambridge University Press, 1975.

ROCHA, G. in: Ensino de Física - Reflexões, Abordagens \& Práticas, editado por José Carlos O. de Jesus e Gustavo Rodrigues Rocha. Editora Livraria da Física, pp. 31-42. São Paulo, 2012.

RUSE, M. Karl Popper's Philosophy of Biology. Philosophy of Science, vol. 44(4), pp. 638-61. Disponível em: www.jstor.org/stable/186943

RUSSELL, B. Conhecimento Humano. Trad. Renato Prelorentzou. São Paulo: Editora Unesp, 2018.

RUSSELL, B. História da Filosofia Ocidental. São Paulo: Companhia Editora Nacional, 1957.

RUSSELL, B. Os Problemas da Filosofia. Trad Jaimir Conte. London: Willians and Norgate, 1912.

SAGAN, C. O Mundo Assombrado Pelos Demônios. São Paulo: Cia. Das Letras, 1996. 
SALÉM, S; KAWAMURA, M. R. D. Ensino de Física no Brasil: catálogo analítico de dissertações e teses (1992-1995). São Paulo: s.n., Projeto USP/BID Formação de Professores de Ciências, 1996.

SANDINO et. al. The Evolution of intelligent design: between religion and science. Rev. Cient. Gen. José Maria Córdova, 16 (22), pp. 61-80, 2018. Disponível em: https://revistacientificaesmic.com/index.php/esmic/article/view/321

SARTON, G. The Study of the History of Science. Cambridge, MA: Harvard University Press, 1936.

SETTLE, T. The Rationality of Science versus the Rationality of Magic, Philosophy of the Social Sciences, 1: pp. 173-94. 1971.

SILVEIRA, F. L., OSTERMAN, F. A Insustentabilidade da Proposta Indutivista de "Descobrir a Lei a Partir de Resultados Experimentais". Caderno Brasileiro de Ensino de Física, v. 19, número especial: pp. 7-27. Jun. 2002.

SLEZAK, P. Sociology of scientific knowledge and scientific education: Part 1. Science \& Education, v. 3, n. 3, pp. 265-94. 1994.

TEIXEIRA, E. et al. A influência de uma abordagem contextual sobre as concepções acerca da natureza da ciência de estudantes de Física. Ciência \& Educação, v. 15, pp. 529-56. 2009.

TYSON, N. D. Astrofísica para Apressados. São Paulo: Planeta, 2017.

VAN FRASSEN, B. C. The Scientific Image. Oxford: Oxford University Press, 1980.

VILAS BOAS, A. et al. História da Ciência e Natureza da Ciência: Debates e Consensos. Caderno Brasileiro de Ensino de Física, v. 30, n. 2, pp. 287-322. 2013.

WAZECK, M. Einsteins Gegner. Die öffentliche Kontroverse um die Relativitätstheorie in den 1920er Jahren. Frankfurt: Campus, 2009.

WHEWELL, W. Mr. Mill's Logic, originalmente publicado em 1849, reimpresso em Robert E. Butts (ed.), William Whewell's Theory of Scientific Method, Pittsburgh, PA: University of Pittsburgh Press, pp. 265-308. 1968.

ZAMBONI, L. M. S. Cientistas, jornalistas e a divulgação científica: subjetividades e heterogeneidades no discurso da divulgação científica. Campinas: Autores Associados. 167p. 2001.

ZANETIC, J. Qual o papel da ciência na formação básica? Atas do IX Simpósio Nacional de Ensino de Física, SBF. 1991.

ZANETIC, J. Física e literatura: uma possível integração no ensino. Cadernos Cedes: Ensino da Ciência, Leitura e Literatura, 41, pp. 46-61. 1997.

ZANETIC, J. Física e Arte: uma ponte entre duas culturas. Pro-Posições, v. 17, n. 1 (49) - jan./abr. 2006. 


\section{APÊNDICE: PROPOSTA DE UMA NOVA VISÃO PARA TEORIAS}

O Critério de Demarcação de Popper, ainda nos dias atuais e a despeito de todas as críticas que recebeu depois de sua formulação, permanece como o mais citado meio de definição entre o que é e o que não é Ciência. Durante o estudo tanto do Critério quanto das críticas que recebeu, especialmente aquelas realizadas por Kuhn, foi-me aos poucos ficando visível uma solução alternativa. Essa solução constitui uma reinterpretação do Critério, buscando superar as críticas que recebeu (inclusive as que recebeu de mim ao longo da dissertação), ao mesmo tempo em que se concilia e se harmoniza com os conceitos kuhnianos de incomensurabilidade e mudança de paradigma.

Parto de um princípio metodológico: a de, junto à crítica de uma ideia, oferecer uma alternativa. Creio que se queremos refutar uma ideia (teoria, doutrina, conceito) qualquer, precisamos oferecer ao mesmo tempo uma solução que Ihe substitua. É claro que uma boa ideia deve ser avaliada por seus próprios méritos. Sem recorrer exclusivamente ao recurso da comparação com outras ideias concorrentes, ela precisa dispor de meios para que seja possível medir o seu valor. Mas lembremo-nos que criamos ideias para explicar o mundo e resolver problemas. Lembremo-nos também que, salvo contradições evidentes, quase nenhuma ideia estará completamente errada, se é que alguma estará. Assim sendo, abandonar uma teoria significa não só abandonar onde ela erra, mas também onde ela acerta (com exceção daquelas raras teorias em que a parte certa não está ligada à errada de forma indissociável). É por isso que alguém que adota uma ideia que foi ou está sendo refutada não a abandonará se não houver uma alternativa que lhe pareça melhor.

Fundamentado nesse princípio, não quero limitar-me às críticas ao Critério de Popper, mas sugerir uma alternativa. Além disso, creio na unificação e na conciliação do pensamento: trata-se do princípio de, sempre que possível, encontrar maneiras de harmonizar correntes de pensamento conflitantes. Essa é a síntese dialética hegeliana, dando um passo para além do conflito entre a tese e a antítese.

Para completar essa breve digressão, aviso que a proposta que aqui será feita é ainda um esboço. Não há, no espaço de um mero apêndice, condições para fornecer um rigor formal a toda uma proposta epistemológica, tal como o próprio Popper fez 
com seu Critério n'A Lógica. Mas definitivamente pretendo empreender a tarefa em um trabalho próximo. Sem mais, vamos à proposta.

O Critério de Falseabilidade de Popper estabelece uma dicotomia entre enunciados metafísicos e enunciados empíricos, pretendendo, dessa forma, resolver o Problema da Demarcação entre o que é e o que não é Ciência. Em resumo, enunciados passíveis de serem provados falsos são empíricos e, por isso, científicos. Os demais, são metafísicos. Consideremos uma teoria como uma coleção de enunciados inter-relacionados (voltarei a essa definição em breve). Pode-se elencar os seguintes problemas com o Critério de Popper: (a) toda teoria pode ser falseada apenas parcialmente (sempre um ou outro enunciado é falseado, nunca a teoria como um todo), o que torna difícil (de fato, nunca ocorre) o abandono de uma teoria por outra motivada unicamente pelo falseamento, (b) toda teoria possui necessariamente enunciados puramente metafísicos - os axiomas - que, por definição, não são falseáveis e (c) mesmo o mais simples dos enunciados empíricos possui um componente metafísico indissociável que jamais poderá ser falseado. A principal consequência desses três pontos é que a divisão dicotômica entre Metafísica e Ciência não parece se adequar a eles; ao contrário, tudo indica que é impossível separá-las, esvaziando de sentido a afirmação de uma suposta demarcação clara e definida entre elas.

Além disso, Popper estabelece que algumas teorias são mais falseáveis do que outras. Para tanto, adota o conceito de conteúdo empírico: quanto maior o número de enunciados falseáveis uma teoria tiver, e quanto mais restritivos eles forem, tanto maior será o seu conteúdo empírico e tanto mais fácil será de falseá-la. Teorias com maior conteúdo empírico "dizem mais" sobre o mundo, de forma que um aumento de conteúdo empírico corresponde a um aumento no conhecimento. Isso é, de fato, um mérito ao Critério de Popper, oferecendo uma resposta ao eterno questionamento da Epistemologia: "Como o conhecimento aumenta?". O objetivo de Ciência seria então o de progredir em direção a teorias com maior conteúdo empírico, passando pela velha e muito criticada ideia de crescimento cumulativo e linear da Ciência.

Utilizando Círculos de Euler, poderíamos representar a demarcação feita por Popper da seguinte maneira: 

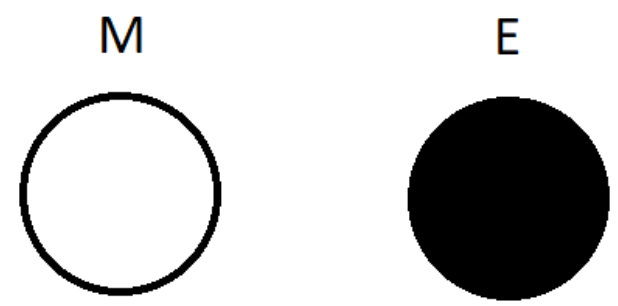

O primeiro conjunto representa uma teoria que possui todos os enunciados classificados como metafísicos, não falseáveis. O segundo conjunto representaria uma teoria que possui enunciados classificados como empíricos, falseáveis. Utilizei a palavra "representa" para o primeiro caso e "representaria" para o segundo por um par de motivos. Primeiro, "representaria" refere-se à intenção de Popper em classificar enunciados como empíricos de forma definitiva. Porém, conforme argumentação que farei a seguir, nenhum enunciado pode se ver livre de seu componente metafísico. Logo, não é exata a afirmação de que certos enunciados são empíricos, pura e simplesmente. Segundo, "representa" refere-se a que é possível que um enunciado seja totalmente metafísico. Isso significa que há uma assimetria na divisão feita por Popper: um enunciado jamais será completamente empírico, mas poderá ser completamente metafísico. Seria, talvez, mais preciso representar uma teoria da seguinte maneira:

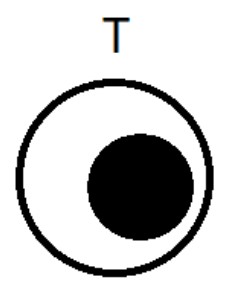

A região branca do conjunto-teoria T representa os enunciados não-falseáveis que a teoria contém. A região preta representa os enunciados empíricos (a posição do círculo ilustrado, levemente deslocado para a direita, é arbitrária e irrelevante). Mas ainda há um porém: os enunciados empíricos que compõe a região preta não são totalmente empíricos (ou seja, não seriam círculos totalmente pretos, mas haveria algo de branco, algo de metafísico, neles). Segue a justificativa para tal.

Como dito anteriormente, uma teoria (qualquer que seja a sua natureza e os objetos que pretende explicar) é uma coleção de enunciados. Expandindo um pouco essa definição, uma teoria é um conjunto hierarquizado de enunciados e conceitos 
primordiais, que são também uma espécie de enunciado, conectados por uma relação de dedução, onde acrescentam-se determinados enunciados criados pelo autor da teoria. No total, temos quatro elementos: (a) Os enunciados primeiros ou axiomas fundamentais, (b) os conceitos primordiais (que, como dito, são também enunciados, exceto aqueles que não são definidos), (c) os enunciados axiomáticos (postulados) secundários e (d) os enunciados logicamente deduzidos. Os elementos (a) e (b), são tomados como certos a priori. O elemento (c) contém aquilo que são considerados como postulados hipotéticos não falseáveis, por serem essencialmente axiomas, enquanto (d) pode ou não ser um conjunto de hipóteses falseáveis. Caso sejam, serão considerados enunciados empíricos, pertencentes a um ramo da Ciência Empírica. Do contrário, a teoria pertence a um outro campo qualquer de conhecimento. Expandirei agora os conceitos de cada um dos elementos acima.

(a) Os enunciados primeiros são metafísicos, começando pelos princípios mais Universais de que temos a disposição para explicar todo e qualquer fenômeno em que estejamos interessados: o Princípio da Causalidade ("o fenômeno em questão precisa ter uma causa adequada"), o Princípio da Uniformidade ("as causas do fenômeno não mudam com o tempo e, portanto, o fenômeno ocorreu, ocorre e ocorrerá da mesma maneira") e até outros um pouco mais específicos, como o da Seleção Natural ("sobrevivem as espécies mais aptas ao seu ambiente"). Esses axiomas, em especial os dois primeiros, só podem ser aceitos a priori (Popper sugere substituir a ideia de apriorismo por uma decisão metodológica — como o resultado, na prática, é o mesmo, ainda que haja uma diferença filosófica, não considerarei a sugestão). Esses enunciados (ou regras metodológicas, na sugestão de Popper) não são passíveis de nenhum tipo de demonstração e praticar Ciência significa aceitá-los. Se não consideramos esses dois axiomas, essas duas verdades metafísicas, como sendo realmente verdadeiras, é melhor que busquemos outra tarefa a qual nos dedicar.

A busca por respostas aos enigmas da natureza pressupõe que tais respostas realmente existam (o Princípio da Causalidade) e que elas não mudarão com o tempo (Princípio da Uniformidade). Não precisamos aceitar que essas respostas estão ao nosso alcance. Ao contrário, pelo menos desde Kant, ou voltando até Xenofonte (ver Popper, 2013, p. 549) tudo indica que não chegaremos a elas de maneira indubitável, imutável e definitiva. Mas precisamos acreditar, ao menos, que possamos vislumbrálas, ou aproximarmos de alguma maneira delas. Torna-se, portanto, estéril e até 
mesmo autossabotante, do ponto de vista da Ciência, negar esses princípios.

Deixando (b) para logo mais, temos (c): os axiomas secundários. Esses são os axiomas específicos da teoria, algumas vezes chamados de postulados. A criação de uma teoria consiste em determinar (elaborar, inventar) esses axiomas secundários, para em seguida deduzir logicamente as suas consequências. Por sua natureza axiomática, eles não são passíveis de demonstração. Eles não podem ser falseados; são metafísicos (ainda que, atualmente, esse caráter seja ignorado ou negado veementemente por alguns praticantes de Ciência). É deles que os enunciados (d), empíricos (falseáveis) ou não, serão derivados, e são eles que justificam e dão valor para os enunciados deles deduzidos. São exemplos de postulados (ou axiomas secundários): o princípio da biogênese ("toda vida vem da vida"), os postulados geométricos de Euclides e os postulados de Bohr para o seu modelo atômico (um deles é o de que "a energia total do elétron permanece constante por se mover em uma órbita sem emitir radiação eletromagnética"). Toda teoria tem os seus postulados/axiomas, mesmo que estejam apenas implícitos em certos casos.

O que talvez não esteja tão claro, e parece ser algo que Popper não considerou em sua análise, é que entram aqui também as definições dos (b) conceitos que são necessários para se explicar a teoria. Esses conceitos são combinados em enunciados, e a validade desses últimos está alicerçada pela maneira como esses conceitos são definidos (existem também elementos que não podem ser definidos, mas esses exigiriam um tratamento muito mais elaborado e que fogem das possibilidades desse trabalho). Esses conceitos incluem a massa, a energia, 0 espaço, o tempo, a carga elétrica e todos os demais do mesmo tipo, os quais chamarei de conceitos metafísicos primordiais. A definição desses conceitos atua exatamente como axiomas, sendo metafísicos e, portanto, livres de qualquer demonstração ou teste empírico. São conceitos que dizem respeito à ontologia da teoria em questão, estando além de qualquer empirismo.

Não se falseiam axiomas; trocamo-los quando não mais nos servem. É assim que surgem as teorias incomensuráveis, assunto que discutirei mais à frente. Popper dizia que um postulado de alto nível (esses que denominei de axiomas metafísicos) podem ser falseados pelo falseamento de suas consequências. Argumento que isso não é verdade, e por um simples motivo: de um conjunto qualquer de axiomas é possível derivar uma quantidade infinita de enunciados que sejam suas 
consequências (ou corolários) e, a não ser que sejam intrinsecamente absurdos e contraditórios, tais axiomas sempre proverão algum enunciado que será corroborado pela experiência, e algum enunciado que será falseado. Assim, quando os enunciados falseados forem identificados, eles terão sido falseados, e não os axiomas que lhes deram origem: podemos simplesmente limitar o alcance dos axiomas, levando em consideração apenas os enunciados que foram corroborados. Exemplo: se identificarmos empiricamente que uma partícula qualquer pode se mover mais rapidamente que a luz (takions?), isso não falsearia os postulados axiomáticos da Relatividade Restrita; isso tão somente limitaria seu alcance a todas as partículas em que não foi observada a possibilidade de se superar a velocidade da luz. É exatamente o que aconteceu com a introdução da ideia cosmológica inflacionária, em que o próprio espaço não está sujeito à limitação de velocidade e deve ter se expandido mais rapidamente que a luz. Portanto, o falseamento de uma consequência de um axioma não falseia o axioma.

Somente partindo de todo esse aparato metafísico (os postulados e os conceitos primordiais) é que se podem deduzir enunciados empíricos, falseáveis. Teorias que não são capazes de deduzir nenhum enunciado empírico serão consideradas como puramente metafísicas (podendo fazer parte de qualquer outro campo de conhecimento que não o da Ciência Empírica). Já expliquei em detalhes anteriormente sobre o conteúdo empírico de uma teoria. Aqui, vou resumir da seguinte maneira: o conteúdo empírico de uma teoria refere-se a quantos enunciados ela proíbe. Isso significa que, se um desses enunciados forem verificados, a teoria estaria falseada. Nego isso, ao afirmar que apenas aquele enunciado estará falseado, mas o restante da teoria que seja independente dele continuará não falseado. Popper ilustrou o conteúdo empírico de teorias da seguinte maneira:

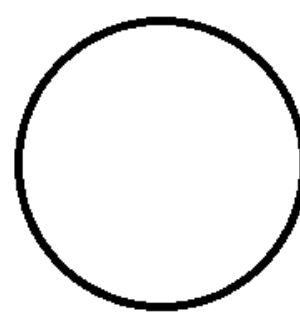

A

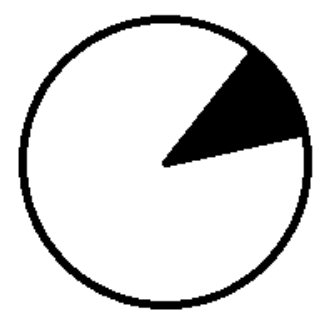

B

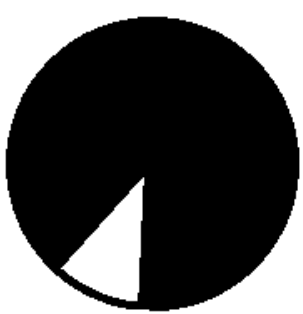

C

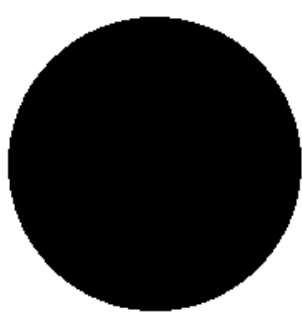

D 
O diagrama A representa uma teoria puramente metafísica. O diagrama B representa uma teoria com baixo conteúdo empírico (a parte preta representa os enunciados falseáveis). $\mathrm{O}$ diagrama $\mathrm{C}$ representa uma teoria com grande conteúdo empírico. O diagrama $D$ representa uma teoria autocontraditória (o que significa, conforme pode-se demonstrar, que ela teria todos os seus enunciados automaticamente falseados). Note que isso significa que é impossível termos uma teoria completamente empírica - seu equivalente lógico é uma teoria autocontraditória (tudo isso pode ser logicamente demonstrado, conforme fez Popper em seu livro).

Dessa forma, toda teoria possui uma parte não falseável (seus enunciados puramente metafísicos - representados pela parte branca dos diagramas) e uma parte falseável (seus enunciados empíricos - representados pela parte preta dos diagramas). Quanto mais enunciados falseáveis uma teoria tiver, maior será a região escura, e maior será o seu conteúdo empírico (pois existirão mais enunciados falseadores - aqueles que podem negar os enunciados empíricos deduzidos). Um ponto subentendido da proposta de Popper é que o conteúdo empírico de uma teoria pode aumentar com o tempo. Assim que os axiomas secundários são estabelecidos, são deduzidos todos os enunciados-consequência. Desses, alguns serão falseáveis e outros não. A proporção entre eles determina a proporção claro-escuro no diagrama de Popper. Acontece que determinar qual enunciado é falseável e qual não é depende de um fator externo à própria teoria: a nossa capacidade tecnológica de alcançarmos aqueles dados empíricos específicos. Vou usar, a partir de agora, a Teoria Especial da Relatividade de Einstein (a qual chamarei apenas de Relatividade daqui por diante) para exemplificar os conceitos aqui abordados.

Um dos enunciados previstos pela Relatividade seria o do aumento, tendendo ao infinito, da energia necessária para se acelerar um corpo a velocidades próximas da luz ${ }^{151}$. Em 1905, quando a Relatividade foi proposta, não havia nenhuma condição de testarmos esse enunciado. Ainda que fizesse uma afirmação sobre o mundo físico,

\footnotetext{
${ }^{151} \mathrm{O}$ aumento de massa do elétron quando em altas velocidades (o que aumenta a quantidade de energia necessária para aumentá-la ainda mais) já era conhecido antes de Einstein propor a Relatividade. Ele era explicado "a partir do momento acumulado ao redor deste, no éter, pelos campos eletromagnéticos" (Martins, 1998b). A Teoria de Einstein, porém, dá a previsão específica de que esse aumento tende ao infinito quando essa velocidade tende a valores próximos ao da luz; e atingir velocidades tão elevadas, e medir esse aumento de massa/energia ainda não era possível em 1905.
} 
o enunciado era metafísico por não ser falseável. Isso é importante: enunciados metafísicos envolvidos em teorias físicas precisam fazer alguma referência ao mundo físico; se fizerem referência a algum outro mundo, como o "mundo divino", "sobrenatural", ou algo assim, deveria ser tratado mais como um enunciado teológico do que metafísico. A Teologia se encarregaria, assim, da ordem sobrenatural de coisas, enquanto que a metafísica cuidaria daquela parte do mundo natural que não está ao alcance de nossos aparelhos de medida. Mas, voltando ao ponto principal, assim que os modernos aceleradores de partículas ficaram disponíveis, entre os quais aqueles capazes de acelerar partículas a velocidades próximas da velocidade da luz, o enunciado em questão passou a ser testável. Ele transformou-se de puramente metafísico em empírico.

Alguém poderia argumentar que o "enunciado sempre foi empiricamente testável, por afirmar algo que é naturalmente testável, independentemente de nossa capacidade de teste". Esse argumento carece de fundamento: qualquer enunciado metafísico poderá um dia vir a ser testável, então deveríamos considerá-los todos como empíricos? A existência (ou não existência) de fantasmas, ou de extraterrestres na galáxia de Andrômeda, ou de formas de matéria hoje imponderáveis etc., deveriam ser considerados empíricos? Ao afirmar, através de uma lei, um valor para uma determinada grandeza (suponhamos, a temperatura), com grau de precisão de cinquenta casas decimais (uma precisão muito maior do qualquer meio disponível consegue dar conta - talvez, jamais alcançável), poderíamos considerar essa uma lei puramente empírica? Creio que não. Qual diferença fundamental existe entre algo não testável e algo não testável até o momento, mas possivelmente testável no futuro? Ambos estão para mais além da verificação objetiva independente, que é o valor mais importante que uma afirmação científica deveria levar em conta.

Não basta determinar o enunciado que falsearia uma teoria: é necessário também especificar um experimento possível de ser realizado para testá-lo. Se o experimento não está ao nosso alcance, o conhecimento empírico acerca daquele enunciado também não está, de maneira que ele deve permanecer como sendo metafísico.

Seguindo essa linha de argumentação, vemos o porquê de uma teoria tender a aumentar o seu conteúdo empírico. A faixa escura do diagrama de Popper tende a aumentar. Esse aumento não ocorre indefinidamente, mas chega a um limite. Esse é 
o trabalho da Ciência Normal de Kuhn: não gerar novidades, mas apenas tratar de encontrar meios para testar mais e mais enunciados já previstos pela teoria, a fim de aumentar o conteúdo empírico da mesma. Alguns enunciados, inevitavelmente, serão falseados. Na verdade, alguns já estarão falseados assim que forem determinados, pois nenhuma teoria é capaz de se ajustar, dentro de seus imperfeitos limites, à Natureza. Como disse mais de uma vez na dissertação, e de acordo com a análise de Kuhn, "toda teoria já nasce falseada por aqueles fenômenos que pretende, sem sucesso, explicar". Se todos os enunciados de uma teoria se adequassem à Natureza e nenhum fosse falseado, isso significaria que teríamos encontrado a teoria perfeita (ao menos naquele campo), um autêntico retrato da realidade, e não haveria mais por que seguir a pesquisa naquela direção. Isso é absurdo e vai de total encontro ao caráter dinâmico da Ciência. O que ocorre simplesmente é que uma teoria só pode ser parcialmente falseada, enquanto o restante dela segue sendo utilizada com êxito pelos pesquisadores. Quando uma teoria está sendo levada até o limite de sua capacidade de fornecer novos enunciados empíricos, mais e mais enunciados serão falseados pelas novas experiências e observações. Esse é o período de crescimento de anomalias e de crise, que levará, de acordo com Kuhn, à mudança de paradigma. Mais adiante, voltarei a esse ponto com o propósito de harmonizar a reinterpretação do Critério de Popper com a ideia de incomensurabilidade de Kuhn.

Dando prosseguimento, em sua abordagem, Popper chegou quase a sugerir a gradação, o continuum, que estou propondo. A impressão que temos, à primeira vista (e é, de fato, o que afirmou Popper), é que os enunciados pertencentes à faixa dos "enunciados falseáveis" não apenas são empíricos, mas puramente empíricos. Pretendo demonstrar que não é esse o caso, pois até o mais simples enunciado empírico possui um fator metafísico, não falseável, dele inseparável. Utilizarei, para tanto, um enunciado retirado d'A Lógica: "Amanhã choverá aqui".

A princípio, esse enunciado parece simples e é perfeitamente falseável: basta estar "aqui", "amanhã" e verificar se "choveu" ou não. Questionando e aprofundando nosso entendimento sobre esses termos todos, logo vemos que a simplicidade é apenas aparente. Um enunciado empírico não apenas afirma a relação entre os termos. Ele também afirma todos os axiomas e definições que utilizamos para efetuar a relação. Ele também assume implicitamente uma ontologia. $O$ termo "amanhã" envolve axiomas e definições de tempo. O termo "aqui" envolve axiomas e definições 
de espaço. E o termo "choverá", além da noção de tempo futuro, envolve todos os conceitos necessários para se definir "chuva". Se definirmos chuva como: "precipitação de, ao menos, $1 \mathrm{~mm} / \mathrm{m}^{2}$ de água", precisaremos das definições de todos esses conceitos e grandezas envolvidos. Sem essas definições, não podemos relacionar os termos e a enunciação torna-se impossível. Mas também é evidente que não podemos seguir em regressão ao infinito, buscando as definições das definições das definições, mas levaremos essas perguntas até certo limite, quando nos depararemos com os conceitos metafísicos primordiais, a ontologia mesmo dos entes envolvidos, alguns dos quais precisarão manter-se indefinidos. Por exemplo, a definição de água nos levará, ao fim, aos conceitos metafísicos e ontológicos primordiais de matéria (talvez até o de energia, dependendo de quais são os outros postulados que estejamos aceitando e levando em conta), de elemento, de substância etc.

Para determinar o "aqui" e o "amanhã", assumiremos axiomas de espaço e de tempo. Se assumimos que o espaço e o tempo são absolutos, ou se são relativos, ou se são de qualquer outra maneira, nenhum experimento poderá jamais falsear qualquer uma dessas concepções. O espaço e o tempo absoluto de Newton não foram falseados; foram simplesmente substituídos por outra concepção - a concepção einsteiniana. Experimentos puderam falsear apenas algumas das deduções que partiram dos conceitos de espaço e tempo absoluto, mas nunca poderiam falsear os conceitos mesmos. Não se testa a "absolutividade" do espaço e do tempo em si, mas apenas uma ou outra das consequências de assumi-la como axioma. Em realidade, conforme cirurgicamente notado por Russell em seu livro Conhecimento Humano, o mais letal para a concepção de espaço e tempo absolutos de Newton não é o fato de estarem "errados" (não há como afirmar que estão), mas o fato de que a Física pode sobreviver sem eles. Como a teoria de Einstein derivava enunciados empíricos que não eram falseados pelas mesmas experiências que falseavam a teoria de Newton, tivemos fortes motivações para abandonar a metafísica clássica em prol da metafísica relativística (e, apenas como consequência, abandonamos a física clássica em prol da física relativística).

Se não há como separar absolutamente a parte metafísica da parte empírica de um enunciado, não há por que classificá-lo como "enunciado empírico puro". A demarcação de Popper seria reinterpretada da seguinte maneira: 


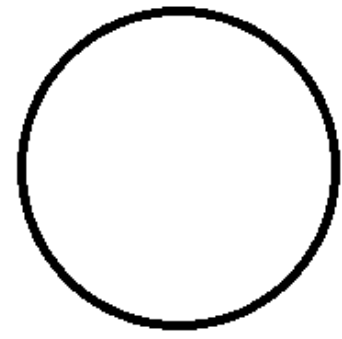

A
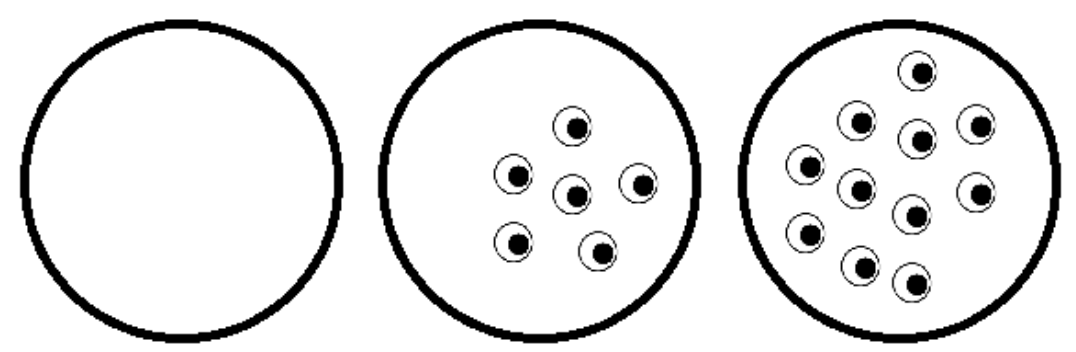

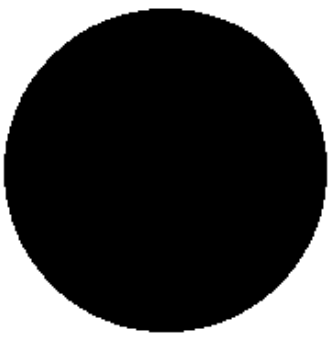

D

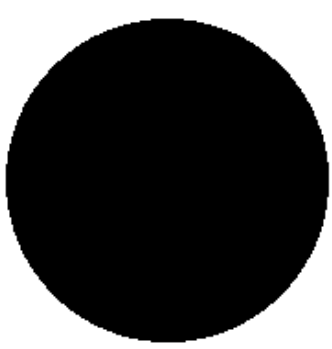

As pequenas esferas (brancas com manchas pretas) representam os enunciados que possuem algum componente empiricamente testável. Cada enunciado possui a sua própria parte branca (a parte metafísica, não testável) e também a parte preta (a parte empírica, testável). A parte branca exterior aos pequenos círculos contém toda a parte puramente metafísica da teoria. Não é por acaso que a quantidade de preto dos diagramas (inferiores) B e C é muito mais reduzida do que a quantidade de preto dos diagramas superiores. Isso serve para levar em conta o fato de que aquilo que podemos saber empiricamente é sempre muito pouco com relação ao que não podemos saber (ao menos até o momento).

Sugiro também utilizarmos uma graduação:

À extrema-esquerda, encontrar-se-ia uma teoria completamente metafísica (desprovida de qualquer número de enunciados empíricos). À extrema-direita, encontrar-se-ia uma teoria completamente empírica. Porém, conforme tudo o que foi argumentado, esse ideal nunca é atingido. As teorias nascem à extrema-esquerda e conforme são mais e mais desenvolvidas, possibilitando serem melhor testadas, vão 
se deslocando assintoticamente para a direita. Em termos dos diagramas, a cada novo enunciado que entra dentro do alcance de nossos testes empíricos (cada nova pequena esfera com mancha preta) veríamos um incremento na região preta total a consequência seria o seu deslocamento para a direita no gradiente acima.

Indo agora para o importante tema da mudança de teorias, é preciso lembrar que a mudança exige o reconhecimento de anomalias. Uma anomalia em andamento precisa ser resolvida, e logo fica claro que nenhuma mudança superficial será suficiente para realizar tal tarefa. Isso significa que a teoria concorrente precisa oferecer uma mudança de fundo, uma mudança metafísica. Normalmente, o criador de uma teoria estabelece os axiomas que irá utilizar, podendo ou não ser os mesmos do paradigma padrão. Alguns desses axiomas, que chamarei de primários, são de tal forma essenciais que nem precisam mais ser explicitados; os já citados Princípios da Causalidade ${ }^{152}$ e da Uniformidade são exemplos.

As grandes mudanças da Ciência ocorridas na história forçaram os criadores de novas teorias a abandonarem os axiomas metafísicos secundários aceitos e trocálos por outros. Assim, como já dito, Einstein abandonou os axiomas metafísicos de espaço e tempo absolutos e trocou-os por um unificado e relativo espaço-tempo. Isso foi resultado dos dois famosos postulados fundamentais da Relatividade: "As Leis da Física devem ser as mesmas em quaisquer referenciais inerciais" e "a velocidade da luz deve ser a mesma para todos os observadores". Repito algo de suma importância: os axiomas de Newton não foram falseados pelos de Einstein, como costumeiramente se insinua. Axiomas nunca podem ser falseados; estão, por natureza, mais além de toda demonstração e teste empírico. O que houve foi uma substituição: abandonamos um em prol do outro. E é aqui que pretendo harmonizar a incomensurabilidade de Kuhn com a reinterpretação do critério de Popper.

Não somos obrigados a adotar a regra de que a nova teoria possua um conteúdo empírico maior do que a anterior. Uma mesma teoria cresce em conteúdo empírico continuamente em consonância com o avanço tecnológico. Mas uma nova teoria, quando substitui a anterior, pode ter, inicialmente, até mesmo um conteúdo

152 É importante não confundir o Princípio da Causalidade com Determinismo. Alguns autores escreveram que a Mecânica Quântica derrubou o Princípio da Causalidade, quando em realidade apenas substituiu o Determinismo pelo Indeterminismo. O Princípio da Causalidade apenas diz que encontraremos explicações para quaisquer fenômenos com os quais nos depararmos. Abandonar esse Princípio é equivalente a abandonar toda investigação científica. 
empírico menor. Esse é um ponto que necessitaria de mais rigor lógico para ser demonstrado, mas, de forma geral, pode ser que nem sequer seja possível comparar duas teorias com relação à quantidade de conteúdo empírico. Isso porque os enunciados metafísicos (e, por consequência, os enunciados empíricos deles deduzidos) não são os mesmos. Logo, não é como se a teoria anterior tivesse os enunciados empíricos $\{A, B, C\}$, enquanto a nova teoria tivesse os enunciados empíricos $\{A, B, C, D\}$. Se assim fosse, seria evidente que a nova teoria é apenas um acréscimo, um incremento simples à anterior. Mas o que temos mais propriamente é a substituição de $\{A, B, C\}$ por $\{D, E, F\}$. Nesse caso, poderíamos apenas em sentido muito limitado dizer que ambas as teorias possuem o mesmo conteúdo empírico, baseando-nos em que ambas possuem o mesmo número de enunciados. Não é possível assumir isso de forma consistente pelo simples fato de que o mais importante não é o número de enunciados, mas o alcance e a precisão dos mesmos. (Lembrando que, em tese, qualquer teoria pode gerar um número infinito de enunciados.)

Por exemplo, enunciados que permitem fazer previsões verdadeiras (que afirmam a ocorrência e a descrição de eventos futuros) possuem muito mais conteúdo empírico do que enunciados capazes apenas de fazer previsões retroativas ${ }^{153}$, justamente por serem mais passíveis de serem rigorosamente testados e terem mais chances de sofrer falseamentos.

A nova teoria poderia ter apenas um enunciado empírico e ter conteúdo maior do que a primeira, ou poderia ter dez vezes mais enunciados empíricos e ter conteúdo menor. Isso mostra a independência entre teorias, de onde surge, naturalmente, a sua incomensurabilidade. Isso nega, total e definitivamente, a ideia de progresso contínuo da Ciência. Esse tipo de progresso exigiria que uma mesma teoria fosse orgânica e paulatinamente alterada enquanto vai se transformando em outra diferente. Mas, certamente, não é o que ocorreu durante as grandes revoluções científicas, onde paradigmas são substituídos por outros radicalmente diferentes, sem evoluírem progressivamente a partir dos anteriores. É possível, inclusive, definir uma mudança de paradigma como sendo a adoção de uma nova teoria que possua enunciados metafísicos diferentes dos da teoria anterior. Aliás, são justamente esses enunciados metafísicos que ditam os programas de pesquisa que serão adotados, os problemas que serão resolvidos, os dados que são irrelevantes e os que serão vistos como

153 Discuto a diferenciação entre os dois tipos de previsão no Capítulo I. 
dignos de atenção.

Uma mudança desse tipo não significa avanço "para mais", nem "para melhor" (ao menos, não em sentido absoluto), mas em direção a responder às questões nas quais temos o nosso maior interesse no momento. Se pudermos falar de um aumento gradual, acumulativo e linear de conhecimento científico, apenas poderemos fazê-lo em contexto de ciência normal, conforme classificado por Kuhn. É só nessa ocasião em que, graças a avanços técnicos, somos capazes de testar cada vez mais enunciados antes inalcançáveis pelo experimento, além de testar com maior precisão aqueles dos quais já tínhamos alguma corroboração. O resultado é um aumento de conteúdo empírico dentro da mesma teoria, dentro do mesmo paradigma, sem mudanças de princípios e de axiomas.

Um dos exemplos utilizados por Kuhn é o da substituição da teoria do flogisto pela teoria da combustão via oxigênio. A primeira possuía, de início, um conteúdo empírico muito maior que a sua substituta. Isso por ter sido utilizada por um longo tempo pelos químicos, que conseguiam explicar uma grande gama de fenômenos, não só relacionados à queima de substâncias, mas também fenômenos envolvendo soluções de ácidos e outros casos (Kuhn, 2012, p. 247). A teoria proposta por Lavoisier não dava conta, a princípio, de explicar satisfatoriamente grande parte desses enunciados que, sim, o eram, quando interpretados à luz do flogisto. Não é por acaso que os debates foram intensos e a mudança foi penosa e, de início, admitida por poucos. O número de fenômenos que uma teoria pode explicar (que é outra forma de ver o seu conteúdo empírico) é apenas um dos critérios para mudança de teorias. O processo é muito mais complexo, tendo Kuhn dado uma das melhores descrições até o momento, mas complementada por outros, como Laudan.

Com essa argumentação preliminar, espero ter conseguido oferecer um esboço suficientemente claro do que pretendi. Os trabalhos de Popper e Kuhn foram profundamente inspiradores a mim e a muitos que amam a Ciência e se interessam pelos problemas da epistemologia: o que podemos saber? Como o saber aumenta? Como explicar o tremendo sucesso que foi e é o empreendimento científico? As respostas dadas por ambos os filósofos são profundas e muito satisfatórias; são a prova viva do valor da Filosofia enquanto instrumento de compreensão e investigação das questões da mais alta importância. Kuhn, em sua ousada originalidade, foi um grande crítico de Popper, mas muito do que disse Popper não só é válido como 
permanece estando entre as melhores contribuições já feitas à Teoria do Conhecimento. Não vejo que uma oposição entre ambos faça jus ao que de melhor ofereceram para nós. Uma conciliação entre ambos me pareceu não só possível, como também pertinente ao momento que vivemos. Seguirei trabalhando nessa empreitada e espero poder compartilhar os resultados dessa pesquisa com todos que acompanharam esse texto até aqui. 